\author{
UNIVERSIDADE DE SÃO PAULO \\ ESCOLA DE ENGENHARIA DE SÃO CARLOS \\ DEPARTAMENTO DE HIDRÁULICA E SANEAMENTO
}

LÍVIA SILVA BOTTA

\title{
HIDRÓLISE E FERMENTAÇÃO DE PAPEL EM LISÍMETRO PARA RECUPERAÇÃO DE COMPOSTOS DE INTERESSE BIOTECNOLÓGICO
}

VERSÃO CORRIGIDA

SÃO CARLOS

2016 
HIDRÓLISE E FERMENTAÇÃO DE PAPEL EM LISÍMETRO PARA RECUPERAÇÃO DE COMPOSTOS DE INTERESSE BIOTECNOLÓGICO

Tese apresentada à Escola de Engenharia de São Carlos, da Universidade de São Paulo, como parte dos requisitos para obtenção do título de Doutor em Ciências: Engenharia Hidráulica e Saneamento.

Orientadora: Profa. Dra. Maria Bernadete Amâncio Varesche 
Autorizo a reprodução e divulgação total ou parcial deste trabalho, por qualquer meio convencional ou eletrônico, para fins de estudo e pesquisa, desde que citada a fonte.

Catalogação-na-publicação

Botta, Lívia Silva

Hidrólise e fermentação de papel em lisímetro para recuperação de compostos de interesse biotecnológico / L. S. Botta; orientadora Maria Bernadete A. Varesche. São Carlos, 2016.

$197 \mathrm{p}$.

Tese (Doutorado) - Programa de Pós-Graduação e Area de concentraç̃o em Hidráulica e Saneamento - Escola de Engenharia de São Carlos da Universidade de São Paulo, 2016.

1.Delineamento composto central (DCC) 2. Hidrogênio - Etanol - Acido acético 3.Sequenciamento massivo 4.Temperatura mesofílica 5.Temperatura termofílica I. Título. 


\section{FOLHA DE JULGAMENTO}

Candidata: Bacharel e Licenciado LIVIA SILVA BOTTA.

Título da tese: "Hidrólise e fermentação de papel em lisímetro para recuperação de biocombustíveis".

Data da defesa: 26/08/2016.

Comissão Julgadora:

Resultado:

Profa. Associada Maria Bernadete Amâncio Varesche Silva (Orientadora)

(Escola de Engenharia de São Carlos/EESC)

Prof. Titular Marcelo Zaiat

(Escola de Engenharia de São Carlos/EESC)

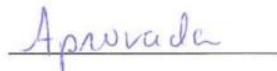

Profa. Dra. Katia Sivieri

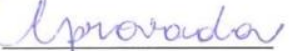

(Universidade Estadual Paulista "Júlio de Mesquita Filho"/UNESP - Araraquara)

Profa. Dra. Lorena de Oliveira Pires Aprovada

(Universidade Estadual Paulista "Júlio de Mesquita Filho"/UNESP - Araraquara)

Profa. Dra. Valéria Reginatto Spiller HPROVADA

(Faculdade de Filosofia, Ciências e Letras de Ribeirão Preto/FFCLRP-USP)

Coordenadora do Programa de Pós-Graduação em Engenharia Hidráulica e Saneamento:

Profa. Associada Maria Bernadete A. Varesche Silva

Presidente da Comissão de Pós-Graduação:

Prof. Associado Luis Fernando Costa Alberto 
Aos meus pais Renata e Romeu. Ao meu marido Felipe.

Com imensa gratidão, dedico. 


\section{AGRADECIMENTOS}

A Deus, pela vida, por sua imensa misericórdia em não me deixar abater pelas dificuldades do caminho, e por renovar meu ânimo a cada manhã. Para quem tem fé, só há paz e esperança;

Aos meus amados pais Renata e Romeu, que com incansáveis e incontáveis apoio, dedicação e oração me ajudaram a ser resiliente e a concluir esta árdua etapa da realização do Doutorado. Obrigada por todo amor e compreensão, sem vocês, eu seria nada!

Ao meu querido esposo Felipe, por me acolher diariamente em seu grande coração, mostrando-me sempre que a vida e seus desafios são mais simples do que me parecem ser. Obrigada pelo amor, paciência e compreensão em todos os momentos atribulados;

A todos os meus meus familiares (Fernandes, Silva, Botta, e agora, Reis) que acompanharam essa jornada e torceram pelo êxito em meu Doutorado;

À Profa. Dra. Maria Bernadete Amâncio Varesche pela orientação, oportunidade, confiança, incentivo e comprometimento. Agradeço-a pela dedicação com que orientou este trabalho.

Ao Prof. Dr. Edson Luiz Silva pela coorientação, interesse, incontáveis discussões técnicas, dedicação e ajuda na realização deste projeto. Agradeço o acolhimento no Laboratório de Controle Ambiental II (DEQ - UFSCar), onde fui capacitada a operar os lisímetros;

Aos queridos amigos Priscila Camiloti e Tiago Palladino pelo grande coração, amizade, acolhimento, bons momentos compartilhados, risadas infinitas e torcida mútua. Ao Tiago pela ajuda imensurável para análise dos resultados do sequenciamento massivo;

À família Borges Rabelo, em especial à Camila, pela amizade, apoio e consolo, disposição em ajudar, trabalho em conjunto, e os bons momentos compartilhados;

À querida Regiane Ratti pela amizade e parceria, trabalho em conjunto e torcida;

À Bruna Gomes pela doce convivência e disposição em ajudar sempre;

Aos queridos Djalma, Adriana, Eduardo, Dagoberto, Carlinha, Rachel, Mara Rúbia, Filipe e Carol Gil pelas viagens, diversão, muitas risadas e momentos divertidíssimos juntos. Obrigada pela doce convivência, sempre dispostos a ajudar quando preciso e a divertir a qualquer momento;

Aos mais que queridos e muito competentes Mariê (Maria Eduarda), Marina Gomes e Lucas Souza. Devo grande parte do meu Doutorado a eles, que estiveram do meu lado para 
superar os desafios da operação dos lisímetros, viraram noites em claro comigo no LPB com boa vontade e que me acompanharam na rota USP e UFSCar muitas e muitas vezes! Sou muito grata e desejo a eles um futuro profissional brilhante!

Aos queridos Marcus Vinícius, Fiaz, Clara e Vanessa pela convivência doce e divertida durante o Doutorado; Agradecimento especial ao Marcus pela disponibilidade em ajudar sempre;

Aos agradáveis colegas e companheiros de laboratório e "luta diária" que convivi durante todos esses anos: Lucas Fuess, Leandro Godói, Guilherme Vuitik, Guilherme Oliveira, Regiane Corrêa, Lorena Oliveira, Lais Américo, Juliana, Fabrício, Tiago Martins, Theo, Bruna Moraes, Gustavo Mockaits, Paulo, Vivian, Inaê, Vinícius, Thais, Simone, Mariana Carosia, Rodrigo Carneiro, Inês, Matheus, Tiago Duarte (Cebola), Kiemi, Rafael Bazola, Adriano, Rogério, Ana Flávia, Daniel, Valéria, Samuel, Ariovaldo, Ana Barana, Davi, Débora, Betão, Pilar, Sandra e Flávia Saia;

Aos Professores Maria Bernadete, Marcelo Zaiat, Márcia Damianovic e Wyclef Marra e, em especial, o Professor Eugênio Foresti pelos ensinamentos compartilhados, cafés divertidos na copa do LPB e pela convivência muito agradável durante todos esses anos;

Às meninas do LCA II da USFCar pelo acolhimento e ajuda: Samantha Santos, Paula Rosa, Mariana Carosia, Morgana, Janaína, Cristiane Reis e Lívia Ottaviano;

À minha querida Samantha Santos pela generosidade e diversão de sempre;

Às amigas Barbara, Lilian, Joice, Bruna e Ana Carla da UNESP pela grande amizade e constante torcida. Obrigada especial para a Joice por me acolher na cidade grande (Campinas). À Lidiani pela amizade e disposição em ajudar.

Aos membros da banca no exame de Qualificação, Prof. Dr. Marcelo Zaiat e Profa. Dra. Kátia Sivieri pela leitura do trabalho e pelas valiosas sugestões;

À queridíssima Janja, sempre pronta para me ajudar no que fosse possível, por quebrar a cabeça comigo muitas vezes, pela amizade e carinho;

À técnica do Dept. de Engenharia Ambiental e amiga Juliana Custódio pela convivência e trabalho conjunto durante o preparo das aulas da graduação no laboratório de Biologia, pelas conversas e apoio, pelo carinho e amizade;

Aos funcionários do Dept. de Engenharia Ambiental Fernando, Edson e Silvana pela disposição em ajudar e convivência diária;

À doce Isabel Sakamoto, sempre bem-humorada e disposta a me ajudar com as análises de Biologia Molecular. Obrigada pela convivência estes anos todos; 
Às especialistas de laboratório Eloísa e Carol pela ajuda e doce convivência durante todos esses anos de Mestrado e Doutorado no LPB;

Aos companheiros de trabalho e amigos da Ergostech pelo convívio, acolhimento, amizade, torcida e paciência. Obrigada pela compreensão e pela ajuda constante para que eu pudesse concluir o Doutorado. Obrigada especial à Luciana Yumi Watari pela compreensão e apoio que precisei durante este último ano.

Ao corpo administrativo do SHS Rose, Sá, Priscila, Flávia, Fernanda, André e todos os funcionários do SHS pela ajuda sempre que necessário;

Ao Conselho Nacional de Desenvolvimento Cientiúfico e Tecnológico (CNPq) pelo apoio concedido por meio da Bolsa de Doutorado (Processo 141584/2012-2 - período de Março 2012 a Agosto/2013).

À Fundação de Amparo à Pesquisa do Estado de São Paulo (FAPESP), pelo apoio concedido por meio da Bolsa de Doutorado (Processo 2013/04200-4) e pelo Projeto Temático (2009/15984-0);

Ao SHS, EESC, USP, CNPq, Capes e FAPESP pelo apoio;

A todos que contribuíram diretamente e indiretamente para a execução e conclusão deste trabalho.

Muito Obrigada! 
"Tudo vale a pena se a alma não é pequena" Fernando Pessoa 


\section{RESUMO}

BOTTA, L. S. Hidrólise e fermentação de papel em lisímetro para recuperação de compostos de interesse biotecnológico. Tese (Doutorado) - Escola de Engenharia de São Carlos, Departamento de Hidráulica e Saneamento, Universidade de São Paulo, São Carlos, 2016.

Neste trabalho avaliou-se a produção de compostos de interesse biotecnológico potenciais vetores energéticos a partir de papel em lisímetros (20L), usando-se consórcio microbiano enriquecido do fluido de rúmen. Para tanto, foi realizado um delineamento composto central (DCC) para verificar a influência de três variáveis independentes na conversão de papel sulfite a hidrogênio e outros compostos orgânicos em lisímetro de bancada. As variáveis testadas foram massa de papel (X1: 500g, 750g e 1000g), teor de umidade papel (X2: 50\%, 65\% e 80\%), e temperatura $\left(\mathrm{X} 3: 35^{\circ} \mathrm{C}, 45^{\circ} \mathrm{C}\right.$ e $\left.55^{\circ} \mathrm{C}\right)$. As respostas avaliadas no DCC foram produção de hidrogênio (Y1; mmol), ácido acético (Y2; mg/L), etanol (Y3; mg/L) e metanol (Y4; mg/L). Para o monitoramento dos lisímetros em relação à hidrólise e fermentação do papel, foram analisados biogás $\left(\mathrm{H}_{2}, \mathrm{~N}_{2}, \mathrm{CO}_{2}\right.$ e $\left.\mathrm{CH}_{4}\right)$ e a concentração de compostos no percolado, como açúcares totais, demanda química de oxigênio (DQO), ácidos orgânicos voláteis (AOVs) e álcoois. Além disso, monitorou-se o $\mathrm{pH}$, alcalinidade e sólidos totais. Sequenciamento massivo do gene RNAr 16S via Plataforma Illumina foi usado para identificação dos micro-organismos do fluido de rúmen in natura, do consórcio enriquecido, e daqueles dos lisímetros R2, R5 e R9. Produção de hidrogênio só foi observada nos lisímetros R1 (25 mmol), R2 (35 mmol) e R5 (3 mmol), sendo os três com umidade inicial de $80 \%$. Em R1 e R2, observou-se elevadas concentrações de ácido acético, de 21.500 e $17.000 \mathrm{mg} / \mathrm{L}$, respectivamente, provavelmente devido à ocorrência de homoacetogênese. Sob temperatura termofílica, especialmente em R5, observou-se consumo de hidrogênio, e produção de etanol $(2.300 \mathrm{mg} / \mathrm{L})$ e metanol $(5.600$ $\mathrm{mg} / \mathrm{L})$. Na condição de $80 \%$ de umidade (R1, R2, R5, R6), verificou-se maiores percentuais de remoção de papel e atividade fermentativa mais acentuada, ao passo que abaixo de $80 \%$, o desenvolvimento microbiano foi desfavorecido, independente da temperatura. Verificou-se consumo muito reduzido de papel e baixas concentrações de AOVs e álcoois para R3, R4, R7 e R8, todos com 50\% umidade. Em R9 e R10, operados a $45^{\circ} \mathrm{C}$ e $65 \%$ de umidade, também verificou-se produção atenuada de AOVs e álcoois, com ausência de hidrogênio. Por meio do DCC, observou-se efeito estatisticamente significativo da umidade do papel na produção de hidrogênio, ácido acético e etanol. Em relação à temperatura, verificou-se efeito positivo estatisticamente significativo na produção de hidrogênio e ácido acético. Por fim, para a massa de papel não se verificou nenhum efeito sobre as respostas analisadas. Os gêneros de bactérias mais abundantes foram: Prevotella no fluido de rúmen in natura (F.N.) Dysgonomonas no fluido de rúmen enriquecido e em R2 $\left(35^{\circ} \mathrm{C}\right)$, Thermicanus em R5 $\left(55^{\circ} \mathrm{C}\right)$ e Phaeospirillum em R9 $\left(45^{\circ} \mathrm{C}\right)$. A umidade foi o parâmetro mais determinante para promover a hidrólise e fermentação do papel; a temperatura foi a principal variável de influência na estrutura das comunidades microbianas dos lisímetros, confirmada pelas diferentes rotas metabólicas observadas sob temperatura mesofílica e termofílica; e os rendimentos de produção dos compostos não foram influenciados pela massa de papel adicionada aos lisímetros.

Palavras-chave: Delineamento composto central (DCC). Hidrogênio - Etanol - Ácido acético. Sequenciamento massivo. Temperatura mesofílica. Temperatura termofílica. 


\begin{abstract}
BOTTA, L.S. Hydrolysis and fermentation of office paper in lysimeter for recovery of compounds of biotechnological interest. Thesis (Doutorado)-Escola de Engenharia de São Carlos, Departamento de Hidráulica e Saneamento, Universidade de São Paulo, 2016.

This study evaluated the production of compounds of biotechnological interest and potential energy vectors from office paper in lysimeters (20L), using a microbial consortium purified from rumen fluid. A central composite design (CCD) was performed to verify the influence of three independent variables on paper conversion to hydrogen and other organic compounds in bench lysimeter. The tested variables were: mass of paper (x1:500g, 750g and 1000g), moisture content (x2: $50 \%, 65 \%$ and $80 \%)$, and incubation temperature $\left(\mathrm{x} 3: 35{ }^{\circ} \mathrm{C}, 45{ }^{\circ} \mathrm{C}\right.$ and $\left.55{ }^{\circ} \mathrm{C}\right)$. The dependent variables of CCD were production of hydrogen (Y1: mmol), acetic acid (Y2: $\mathrm{mg} / \mathrm{L}$ ), ethanol (Y3:mg/L) and metanol (Y4:mg/L). For monitoring the lysimeters in relation to paper hydrolysis and fermentation, analyses of biogas $\left(\mathrm{H}_{2}, \mathrm{~N}_{2}, \mathrm{CO}_{2}\right.$ and $\left.\mathrm{CH}_{4}\right)$ and the organic compounds'concentrations in the leachate, such as, total sugars, chemical oxygem demand, volatile organic acids (VOA's) and alcohols were conducted during operation. Alcalinity, $\mathrm{pH}$ and total solids content of the leachate were also monitored. Massive sequencing of rRNA $16 \mathrm{~S}$ (Illumina) was carried out for identification of the microorganisms of the in natura rumen fluid, the purified consortium, and those collected from lysimeters R2, R5 and R9. Hydrogen production was detected only in lysimeters R1 (25 mmol), R2 (35 mmol) and R5 (3 mmol), all of them operated with $80 \%$ of moisture content. In R1 and R2, high concentrations of acetic acid, of 21.500 and 17.000 , respectively, were due to the likely occurrence of homoacetogenesis. Under thermophilic temperature, especially R5, the hydrogen production was detected in low quantity, and the highlight was the production of ethanol and methanol, with concentrations around 2.300 and $5.600 \mathrm{mg} / \mathrm{L}$, respectively. At $80 \%$ moisture condition (R1, R2, R5, R6), high percentages of paper removal and sharp fermentative activity were observed. However, at lower moisture conditions, the microbial growth was unfavored, independent of the temperature. Low paper consumption and reduced concentrations of OVA's and alcohols were detected in R3, R4, R7 and R8, all of them operated with $50 \%$ of moisture content. In $\mathrm{R} 9$ and $\mathrm{R} 10$, operated at $45{ }^{\circ} \mathrm{C}$ and $65 \%$ of moisture, there was also attenuated production of VOA's and alcohols, with absence of hydrogen. According to CCD statistical analysis, paper moisture content had positive effect statistically significative on hydrogen, acetic acid and etanol production. The temperature had positive effect on hydrogen and acetic acid production. And the mass of paper dit not have effect statistically significative for any dependent variables. The most abundant bacterial genus was: Prevotella in the in natura rumen fluid (F.N.) Dysgonomonas in the purified consortium and R2 $\left(35^{\circ} \mathrm{C}\right)$, Thermicanus in R5 (55 ${ }^{\circ} \mathrm{C}$ ) and Phaeospirillum in $\mathrm{R} 9\left(45^{\circ} \mathrm{C}\right)$. In conclusion, moisture content was the main parameter to promote paper hydrolysis and fermentation; temperature was the principal variable that influenced the structure of microbial community, confirmed by the different metabolic route observed under mesophilic and thermophilic conditions; and the production yields of the compounds were not influenced by the mass of paper added to the lysimeters.
\end{abstract}

Keywords: Central composite design (CCD). Hydrogen - Ethanol - Acetic acid. Massive sequencing. Mesophilic condition. Thermophilic condition. 


\section{LISTA DE FIGURAS}

Figura 3.1 - Fluxograma de reações metabólicas da fermentação mista............................28

Figura 3.2 - Fórmula estrutural da celulose: polímero formado por monômeros de glicose interligados pela ligação $\beta-1,4$ glicosídica ..........................................................34

Figura 3.3 - Metabolismos desenvolvidos pela microbiota do rúmen...............................44

Figura 4.1 - Fluxograma das atividades desempenhadas desde a obtenção do fluido de rúmen in natura até a operação dos lisímetros no modelo Fatorial $2^{3}$.

Figura 4.2 - Coleta do fluido de rúmen bovino: (A) fístula permanente na porção do rúmen; (B) retirada do material lignocelulósico embebido no fluido ruminal; (C) vasilhame térmico

Figura 4.3 - (A) Desenho esquemático do reator (baseado em Baldochi, 1997); (B)

Montagem Lisímetros; (C) Detalhe do Bico Aspersor .64

Figura 5.1 - Número de mol de hidrogênio e gás carbônico no headspace do lisímetro ETAPA I

Figura 5.2 - Compostos orgânicos solúveis no percolado - ETAPA I. (A) Ácido acético, butírico e propiônico; (B) Ácido isobutírico, isovalérico, valérico e caproico; (C) Álcoois: metanol, etanol e n-butanol

Figura 5.3 - (A) DQO (bruta e filtrada) e (B) Carboidratos totais solúveis (bruta e filtrada) no percolado - ETAPA I. .86

Figura 5.4 - Número de mol de hidrogênio e gás carbônico no headspace do lisímetro ETAPA II

Figura 5.5 - Compostos orgânicos solúveis no percolado - ETAPA II. (A) Ácido acético, butírico e propiônico; (B) Ácido isobutírico, isovalérico, valérico e caproico; (C) Álcoois: etanol e n-butanol.

Figura 5.6 - (A) DQO (bruta e filtrada) e (B) Carboidratos totais solúveis (bruta e filtrada) do percolado - ETAPA II 93

Figura 5.7 - Número de mol de Hidrogênio nas condições R1 (1000 g; 80\%; $35^{\circ}$ C), R2

$\left(500 \mathrm{~g} ; 80 \% ; 35^{\circ} \mathrm{C}\right)$ e $\mathrm{R5}\left(1000 \mathrm{~g} ; 80 \% ; 5^{\circ} \mathrm{C}\right)$ 
Figura 5.8 - Compostos orgânicos solúveis no percolado do R1 (1000 g; 80\%; 35C). (A) Ácidos orgânicos: acético, butírico e propiônico; (B) Ácidos orgânicos: isobutírico, isovalérico, valérico e caproico; $(C)$ Álcoois: etanol e n-butanol 102

Figura 5.9 - Compostos orgânicos solúveis no percolado do R2 (500 g; 80\%; 35 C). (A) Ácidos orgânicos: acético, butírico e propiônico; (B) Ácidos orgânicos: isobutírico, isovalérico, valérico e caproico; (C) Álcoois: etanol e n-butanol 104

Figura 5.10 - Compostos orgânicos solúveis no percolado de R4 (500 g; 50\%; $\left.35^{\circ} \mathrm{C}\right)$. (A) Ácidos orgânicos: acético, butírico e propiônico; (B) Ácidos orgânicos: isobutírico, isovalérico, valérico e caproico; (C) Álcoois: etanol e metanol 106

Figura 5.11 - Compostos orgânicos solúveis no percolado de $\mathrm{R5}\left(1000 \mathrm{~g} ; 80 \%\right.$; $\left.55^{\circ} \mathrm{C}\right)$. (A) Ácidos orgânicos: acético, butírico e propiônico; (B) Ácidos orgânicos: isobutírico, isovalérico, valérico e caproico; (C) Álcoois: etanol, metanol e n-butanol. 109

Figura 5.12 - Compostos orgânicos solúveis no percolado do R6 (500 g; 80\%; 55C). (A) Ácidos orgânicos: acético, butírico e propiônico; (B) Ácidos orgânicos: isobutírico, isovalérico, valérico e caproico; (C) Álcoois: etanol e metanol

Figura 5.13 - Compostos orgânicos solúveis no percolado do $\mathrm{R8}\left(1000\right.$ g; 50\%; $\left.5^{\circ} \mathrm{C}\right)$. (A) Ácidos orgânicos: acético, butírico e propiônico; (B) Ácidos orgânicos: isobutírico, isovalérico, valérico e caproico; (C) Álcoois: etanol e metanol 113

Figura 5.14 - Compostos orgânicos solúveis no percolado de R9 $\left(750\right.$ g; $50 \%$; $\left.45^{\circ} \mathrm{C}\right)$. (A) Ácidos orgânicos: acético, butírico e propiônico; (B) Ácidos orgânicos: isobutírico, isovalérico, valérico e caproico; (C) Álcoois: etanol e metanol ...................................116

Figura 5.15 - Compostos orgânicos solúveis no percolado de R10 (750 g; 50\%; $\left.45^{\circ} \mathrm{C}\right)$. (A) Ácidos orgânicos: acético, butírico e propiônico; (B) Ácidos orgânicos: isobutírico, isovalérico, valérico e caproico; (C) Álcoois: etanol e metanol .................................118

Figura 5.16 - Superfície de Resposta para a Resposta Hidrogênio, em função do teor de umidade do substrato (X2) e temperatura de incubação (X3) 127

Figura 5.17 - Curva de contorno para a Resposta Hidrogênio, em função do teor de umidade do substrato (X2) e temperatura de incubação (X3) 128

Figura 5.18 - Superfície de Resposta para a Resposta Ácido Acético, em função do teor de umidade do substrato (X2) e temperatura de incubação (X3) 128

Figura 5.19 - Curva de contorno para a Resposta Ácido acético, em função do teor de umidade do substrato (X2) e temperatura de incubação (X3)

Figura 5.20 - Produção de Etanol em função da Massa de papel adicionada (A); teor de umidade do papel (B) e temperatura de operação (C) 
Figura 5.21 - Variação temporal da DQO total (A) e DQO solúvel (B) nos Lisímetros R1 $\left(1000 \mathrm{~g} ; 80 \% ; 3^{\circ} \mathrm{C}\right), \mathrm{R} 2\left(500 \mathrm{~g} ; 80 \% ; 3^{\circ} \mathrm{C}\right)$ e R4 $\left(1000 \mathrm{~g} ; 50 \% ; 3^{\circ} \mathrm{C}\right)$ .134

Figura 5.22 - Variação temporal das concentrações de Carboidratos totais (A) e

Carboidratos solúveis (B) nos Lisímetros R1 (1000 g; 80\%; 35 C), R2 (500 g; 80\%;

$\left.35^{\circ} \mathrm{C}\right)$ e R4 (1000 g; $\left.50 \% ; 3^{\circ} \mathrm{C}\right)$ 135

Figura 5.23 - Variação temporal da DQO total (A) e DQO solúvel (B) nos Lisímetros R5 $\left(1000 \mathrm{~g} ; 80 \% ; 5^{\circ} \mathrm{C}\right), \mathrm{R6}\left(500 \mathrm{~g} ; 80 \% ; 5^{\circ} \mathrm{C}\right)$ e R8 $\left(1000 \mathrm{~g} ; 50 \% ; 5^{\circ} \mathrm{C}\right)$ 137

Figura 5.24 - Variação temporal das concentrações de Carboidratos totais (A) e

Carboidratos solúveis $(\mathrm{B})$ nos Lisímetros R5 (1000 g; 80\% ; 55 C), R6 (500 g; 80\%; $\left.55^{\circ} \mathrm{C}\right)$ e $\mathrm{R8}\left(1000 \mathrm{~g} ; 50 \% ; 5^{\circ} \mathrm{C}\right)$ 138

Figura 5.25- Variação temporal da DQO total (A) e DQO solúvel (B) nos Lisímetros R9 $\left(750 \mathrm{~g} ; 65 \% ; 45^{\circ} \mathrm{C}\right)$ e $\mathrm{R} 10\left(750 \mathrm{~g} ; 65 \% ; 45^{\circ} \mathrm{C}\right)$ .140

Figura 5.26 - Variação temporal das concentrações de Carboidratos totais (A) e

Carboidratos solúveis (B) nos Lisímetros R9 (750 g; 65\% ; 45 C) e R10 (750 g; $\left.65 \% ; 45^{\circ} \mathrm{C}\right)$

Figura 5.27 - Dendrograma baseado no coeficiente de similaridade de Pearson

(UPGMA) a partir do padrão de bandas do DGGE do gene RNAr 16S para o Domínio Bacteria. Legenda: F.P.: fluido de rúmen enriquecido; R1: 1000 g, 80\%, $3^{\circ} \mathrm{C}$; R2: $500 \mathrm{~g}, 80 \%, 3^{\circ} \mathrm{C}$; R3: $500 \mathrm{~g}, 50 \%, 3^{\circ} \mathrm{C}$; R4: $1000 \mathrm{~g}, 50 \% 5^{\circ} \mathrm{C}$; R5: $1000 \mathrm{~g}, 80 \%, 5^{\circ} \mathrm{C}$; R6: $500 \mathrm{~g}, 80 \%, 5^{\circ} \mathrm{C}$, ; R7: $500 \mathrm{~g}, 50 \%, 5^{\circ} \mathrm{C}$; R8: $1000 \mathrm{~g}, 50 \%$, $5^{\circ} \mathrm{C}$; R9: $750 \mathrm{~g}, 65 \%, 4^{\circ} \mathrm{C}$; R10: $750 \mathrm{~g}, 65 \%, 4^{\circ} \mathrm{C}$ .151

Figura 5.28 - Curvas de rarefação definidas para a porcentagem de similaridade de $97 \%$ (nível de espécie). Legenda: (A) F.N. (fluido de rúmen in natura); (B) F.P. (fluido de rúmen enriquecido); (C) lisímetro $\mathrm{R} 2\left(35^{\circ} \mathrm{C}, 500 \mathrm{~g}, 80 \%\right)$; (D) lisímetro $\mathrm{R5}\left(5^{\circ} \mathrm{C}\right.$, $1000 \mathrm{~g}, 80 \%)$; (E) lisímetro R9 (45ㄷ, $750 \mathrm{~g}, 65 \%)$ 155

Figura 5.29 - Dendrograma baseado no índice de Bray-Curtis para as amostras F.N.

(fluido de rúmen in natura), F.P. (fluido de rúmen enriquecido), $\mathrm{R} 2\left(35^{\circ} \mathrm{C} ; 500 \mathrm{~g}\right.$; $80 \%)$, R5 (55 $\left.{ }^{\circ} \mathrm{C} ; 1000 \mathrm{~g} ; 80 \%\right)$ e R9 $\left(45^{\circ} \mathrm{C} ; 750 \mathrm{~g} ; 65 \%\right)$ 158

Figura 5.30 - Diagrama de Venn da presença e ausência de filos em função das sequências das amostras do fluido de rúmen in natura (F.N.) e fluido de rúmen enriquecido (F.P.) 159

Figura 5.31 - Abundância relativa de filo: (A) F.N.: fluido de rúmen in natura e (B) F.P.: fluido de rúmen enriquecido. 
Figura 5.32 - Diagrama de Venn da presença e ausência de filos em função das sequências das amostras do fluido de rúmen enriquecido (F.P.), R2 $\left(3^{\circ} \mathrm{C}\right.$; $500 \mathrm{~g}$; $80 \%)$, R5 (55 $\left.{ }^{\circ} \mathrm{C} ; 1000 \mathrm{~g} ; 80 \%\right)$ e R9 $\left(45^{\circ} \mathrm{C} ; 750 \mathrm{~g} ; 65 \%\right)$

Figura 5.33 - Abundância relativa de filo (A) lisímetro R2 $\left(500 \mathrm{~g} ; 80 \%, 35^{\circ} \mathrm{C}\right)$; (B) lisímetro R5(1000 g; 80\% ; 55 $\left.{ }^{\circ} \mathrm{C}\right)$ e (C) lisímetro R9 (750 g; 65\% ; 45ㅇ). .163

Figura 5.34 - Diagrama de Venn da presença e ausência de gêneros em função das sequências nas amostras de fluido de rúmen in natura (F.N.) e fluido de rúmen enriquecido (F.P.)

Figura 5.35 - Abundância relativa de gênero: (A) fluido de rúmen in natura (F.N.) (B) fluido de rúmen enriquecido (F.P.)

Figura 5.36 - Diagrama de Venn da presença e ausência de gêneros em função das sequências nas amostras fluido de rúmen enriquecido (F.P.), lisímetro R2 (500 g; $\left.80 \% ; 3^{\circ} \mathrm{C}\right)$, lisímetro R5 (1000 g; 80\%; 55 C) e lisímetro R9 (750 g; 65\%; $\left.45^{\circ} \mathrm{C}\right) 166$

Figura 5.37 - Abundância relativa de gênero: (A) lisímetro R2 (500 g; 80\%; 35 C), (B) lisímetro R5 (1000 g; $\left.80 \% ; 5^{\circ} \mathrm{C}\right)$ e (C) lisímetro R9 $\left(750 \mathrm{~g} ; 65 \% ; 45^{\circ} \mathrm{C}\right)$. 


\section{LISTA DE TABELAS}

Tabela 3.1 - Composição dos resíduos de papel

Tabela 3.2 - Caracterização dos diferentes tipos de papel, consumo total de carboidratos e rendimentos de hidrogênio.

Tabela 3.3 - Constante cinética de hidrólise de celulose por micro-organismos ruminais e não-ruminais .41

Tabela 4.1 - Composição da Solução de Solubilização 56

Tabela 4.2 - Sais e Reagentes que compõem o Tampão PBS 10X. .57

Tabela 4.3 - Composição da Solução de Vitaminas do Meio C . 58

Tabela 4.4 - Composição dos Meios de cultura testados para enriquecimento das populações celulolíticas e fermentativas do fluido de rúmen .58

Tabela 4.5 - Composição do Meio C reformulado 61

Tabela 4.6 - Volume inicial de solução do meio mineral, inóculo e volume de aspersão do meio. .67

Tabela 4.7 - Variáveis independentes e Variáveis Respostas do Fatorial $2^{3}$ 68

Tabela 4.8 - Operação dos Lisímetros no Planejamento Experimental

Tabela 4.9 - Análises de Monitoramento do percolado após sua liberação nos lisímetros 71

Tabela 4.10 - Iniciadores para Dominio Bacteria .74

Tabela 4.11 - Condições utilizadas na PCR para o DGGE 74

Tabela 4.12 - Parâmetros de alfa-diversidade .77

Tabela 5.1 - Parâmetros físico-químicos de monitoramento do percolado da Etapa I....87

Tabela 5.2 - Parâmetros físico-químicos do percolado da Etapa II..................................94

Tabela 5.3 - Caracterização do afluente para umidificação e inoculação do Papel nos Lisímetros R1 a R10. .97

Tabela 5.4 - Parâmetros ao Início da operação dos lisímetros de R1 a R10 .98

Tabela 5.5 - Parâmetros obtidos pelo ajuste da produção de hidrogênio no modelo de Gompertz modificado 100

Tabela 5.6 - Valores empíricos das variáveis respostas monitoradas durante a fermentação acidogênica do papel nos lisímetros nas diferentes condições de processo aplicadas 
Tabela 5.7 - Análise da significância estatística dos efeitos das variáveis (X) sobre as respostas $(\mathbf{Y})$

Tabela 5.8 - Modelos matemáticos de cada variável resposta com os parâmetros estatisticamente significativos, valores de porcentagem de variação explicada $\left(R^{2}\right)$ e Fcal para as respostas segundo as condições do DCC..................................................126

Tabela 5.9 - Período em que houve a primeira detecção de percolado nos lisímetros ...132 Tabela 5.10 - Parâmetros físico-químicos de monitoramento do percolado dos lisímetros nas condições $R 1$ a $R 10$ 142

Tabela 5.11 - Percentual de remoção de papel nas condições estudadas. 145

Tabela 5.12 - Análise comparativa dos parâmetros analisados nos lisímetros R1-R10.148

Tabela 5.13 - Resultados do sequenciamento das amostras F.N., F.P., R2, R5 e R9.....154

Tabela 5.14 - Principais gêneros identificados nas 5 amostras estudadas e suas características metabólicas 


\section{SÚMARIO}

1 INTRODUÇÃO ...................................................................................................................................21

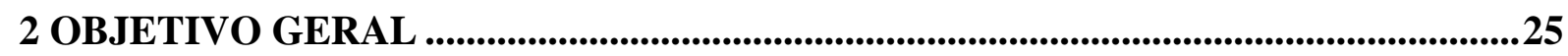

3 REVISÃO BIBLIOGRÁFICA .............................................................................................27

3.1 Produção biológica de hidrogênio, ácidos orgânicos e álcoois e os principais fatores

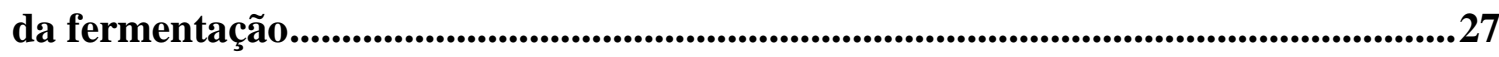

3.2 Produção de energia sustentável a partir de resíduos celulósicos................................33

3.3 Degradação da celulose com fluido de rúmen como fonte de micro-organismos celulolíticos e fermentativos .....................................................................................39

3.4 Processos biológicos consumidores de hidrogênio ...............................................................43

3.5 Ácidos Orgânicos Voláteis - subprodutos de interesse biotecnológico..........................47

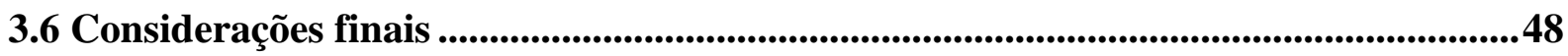

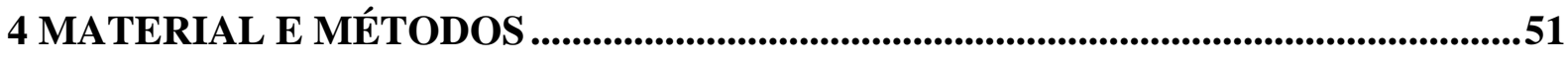

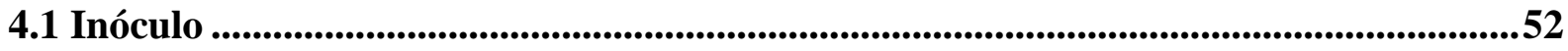

4.1.1 Obtenção de Consórcio Microbiano Celulolítico e Fermentativo a Partir do Fluido de Rúmen. 53

4.1.2 Enriquecimento das Populações Celulolíticas e Fermentativas do Fluido de Rúmen

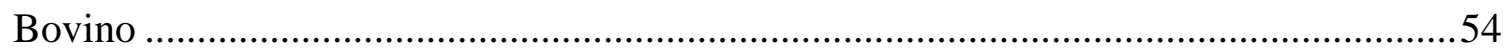

4.1.3 Enriquecimento e Manutenção do Inóculo Purificado ...................................................55

4.2 Preparação de Soluções e Meios de Cultura ..................................................................55

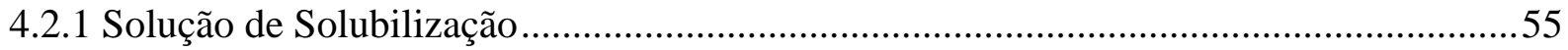

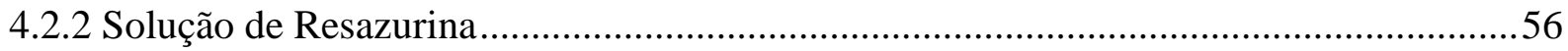

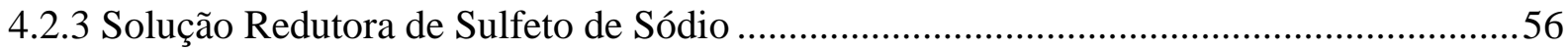

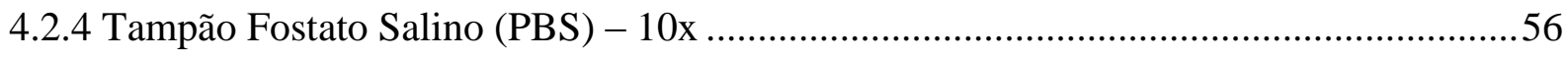

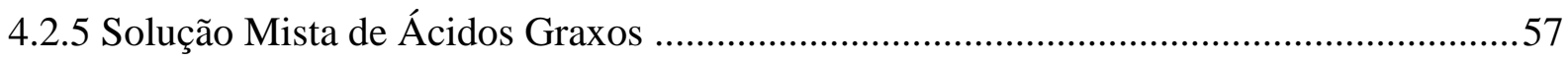

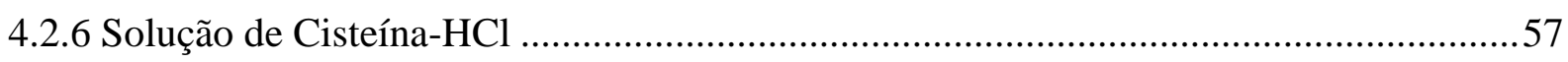

4.2.7 Preparo da Solução de Vitaminas ................................................................................57

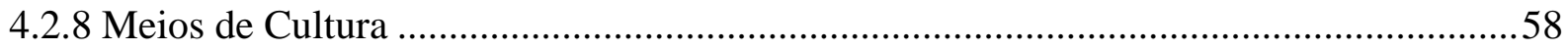

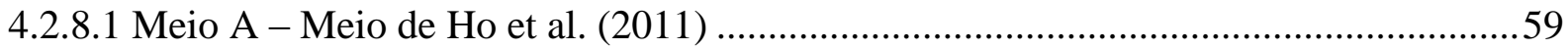

4.2.8.2 Meio B - Meio de cultivo de Ruminococcus albus ...................................................60 
4.2.8.3 Meio C - Meio CAM (Cellulose Anaerobe Medium) ...................................................60

4.3 Definição do Meio de Cultivo para Bactérias Celulolíticas Anaeróbias........................60

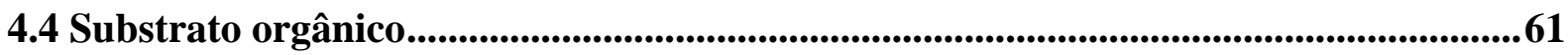

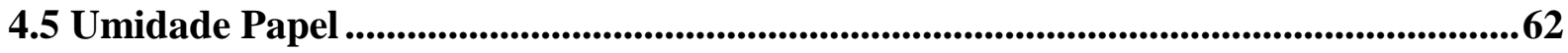

4.6 Lisímetro .....................................................................................................................................62

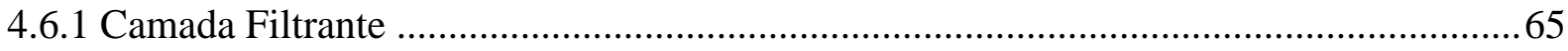

4.6.2 Procedimentos para o Preenchimento dos Lisímetros ..................................................65

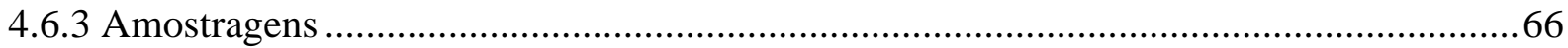

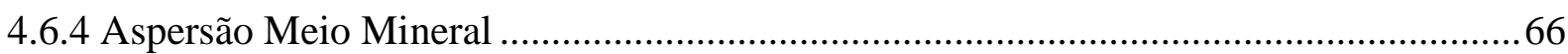

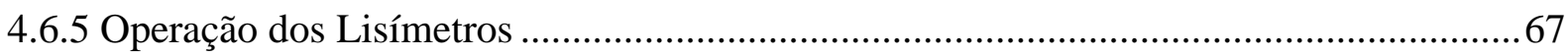

4.6.5.1 Operação dos Lisímetros: Planejamento Experimental ..............................................67

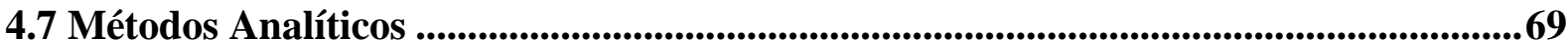

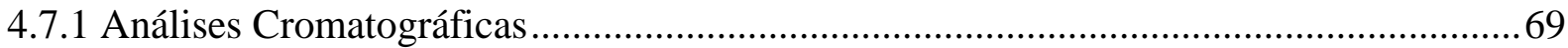

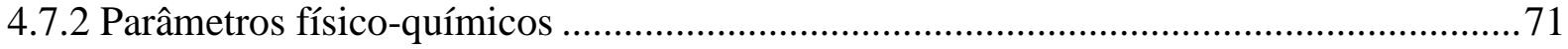

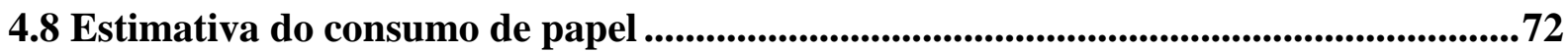

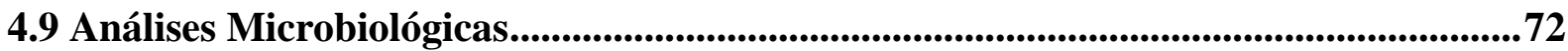

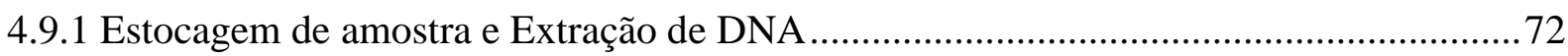

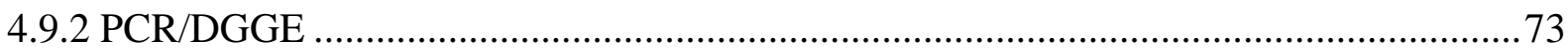

4.9.3 Sequenciamento do gene rRNA 16S - Plataforma Illumina (Miseq) …........................75

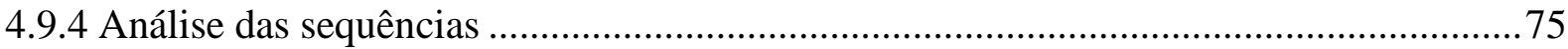

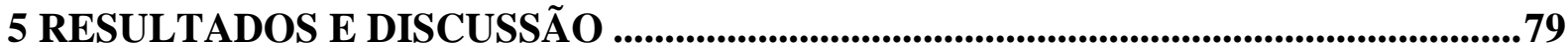

5.1 Cultivo e Enriquecimento do Fluido de Rúmen para Obtenção de Consórcio

Microbiano Celulolítico e Fermentativo............................................................................79

5.2 Operação do Protótipo de Lisímetro: monitoramento...............................................82

5.3 Operação do Lisímetro no modelo de Planejamento Experimental (Fatorial $2^{3}$ ) ......96

5.4 Análise Estatística do Delineamento Composto Central (Fatorial $2^{3}$ )........................120

5.4.1 Caracterização físico-química do percolado............................................................... 132

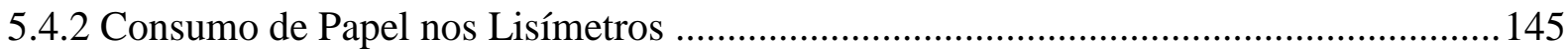

5.5 Análise Comparativa entre as condições de operação do lisímetro propostas no planejamento experimental ....................................................................................................................148

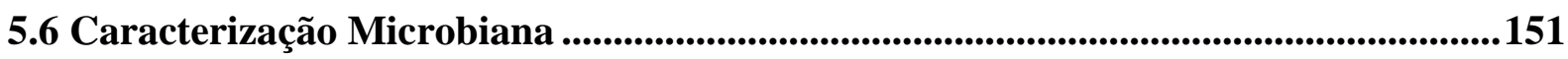

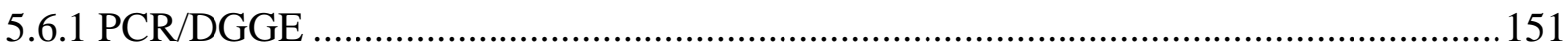

5.7 Diversidade Microbiana................................................................................................................153 


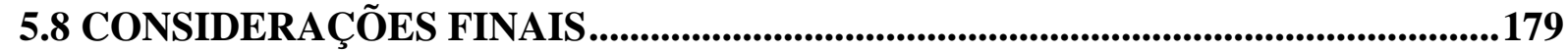

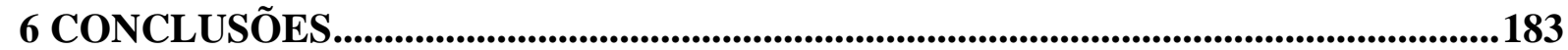

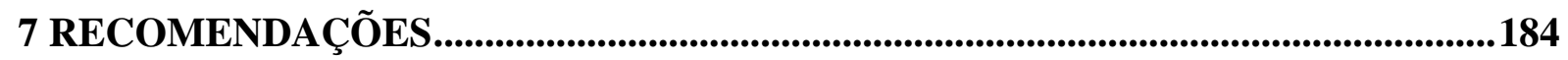

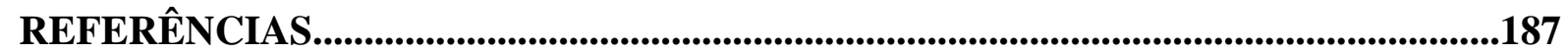





\section{INTRODUÇÃO}

As preocupações com os efeitos da mudança climática e com a segurança energética são proeminentes no cenário energético mundial. Segundo a Administração de Informação de Energia (EIA) dos Estados Unidos, o consumo de energia está previsto para aumentar em 50\% até 2.030 (Wang et al., 2013).

A maior parte da demanda energética é compensada a partir de fontes de energia convencionais, como o carvão, petróleo e gás natural. Porém, dois problemas principais que os países enfrentam com estes combustíveis convencionais são os seguintes: (i) estas fontes de energia serão extintas; (ii) a obtenção de energia a partir dos combustíveis convencionais gera poluição (SAXENA; ADHIKARI, GOYAL, 2009). Sabe-se que a emissão de dióxido de enxofre (SO2) pela combustão de combustíveis fósseis é a maior causa de chuva ácida, e que o aumento das emissões de gases estufa, como por exemplo, dióxido de carbono $\left(\mathrm{CO}_{2}\right)$, é uma ameaça ao clima mundial. Caso estas emissões continuem elevadas, algumas calamidades naturais serão mais drásticas, como variações climáticas, chuvas escassas ou excessivas e outros desequilíbrios.

Os fatores expostos acima têm estimulado a pesquisa por fontes alternativas de energia para suprir o aumento da demanda. Sabe-se que a produção de energia pode ser obtida a partir de recursos renováveis, sem o uso exclusivo de combustíveis fósseis. Processos biológicos naturais, tais como fermentação e digestão anaeróbia, são considerados alternativas ambientalmente favoráveis para promover a geração de energia limpa e renovável, por exemplo por meio da produção de hidrogênio e outros vetores energéticos, como ácidos orgânicos e álcoois, e sua combustão (URBANIEC, BAKKER, 2015).

Embora o hidrogênio não esteja prontamente disponível em sua forma molecular, é um elemento muito abundante na natureza, principalmente em moléculas orgânicas, o que o torna um recurso renovável e de fácil acesso. Ademais, esta molécula contém a maior densidade energética por unidade de massa (142 MJ/ $\mathrm{kg} \mathrm{H}_{2}$ ), e sua combustão gera como produtos energia e vapor d'água. Ao passo que carreadores como o metano, a gasolina e o etanol têm teores energéticos inferiores, de aproximadamente 55,7, 44,4 e 26,8 MJ/kg, respectivamente, e sua combustão leva à emissão de gás carbônico à atmosfera (SCHLAPBACH, ZÜTTEL, 2005; THOMAS et al., 2011). Devido às 
considerações citadas acima, pode-se dizer que a geração de energia baseada na produção de hidrogênio a partir de resíduos orgânicos renováveis e sua combustão é uma alternativa sustentável.

A produção biológica de hidrogênio pode ser obtida por meio da biofotólise da água, fotofermentação e fermentação da matéria orgânica. A fermentação é um conjunto de processos que pode ser dividido em três grupos: fermentação da matéria orgânica, fotofermentação, que depende da disponibilidade de luz, e os processos de dois estágios que combinam a fermentação da matéria orgânica, tanto com fotofermentação, quanto com a bioeletrogênese em células a combustível microbianas (KAPDAN, KARGI, 2006; URBANIEC, BAKKER, 2015). A ocorrência dos micro-organismos nestes processos é distinta, tal como as condições operacionais utilizadas, tais como $\mathrm{pH}$, temperatura, luminosidade, anaerobiose, entre outras.

A fermentação da matéria orgânica, por exemplo, pode ser realizada sob condição mesófila, termófila e hipertermófila, em função das características dos micro-organismos. Ademais, variedades de compostos orgânicos são considerados potencialmente fermentáveis por ampla diversidade filogenética de micro-organismos anaeróbios, a pressão ambiente e ausência de luz (KAPDAN, KARGI, 2006).

A fermentação acidogênica ou acidogênese é a primeira etapa do processo de digestão anaeróbia da matéria orgânica solúvel a metano e gás carbônico. Ampla variedade de bactérias está envolvida na acidogênese, na qual a matéria orgânica (carboidratos, lipídeos e proteínas, por exemplo) é convertida em gás hidrogênio, ácidos orgânicos e álcoois (COHEN et al., 1979). As principais bactérias heterotróficas envolvidas no processo de acidogênese, com produção de hidrogênio, incluem as anaeróbias estritas, por exemplo, as do gênero Clostridium e Thermoanaerobacterium, e as anaeróbias facultativas, tal como Enterobacter (KAPDAN, KARGI, 2006).

Sabe-se que por muito tempo a produção de hidrogênio foi avaliada com o uso de culturas puras de bactérias fermentativas, a fim de caracterizar cineticamente, sob diferentes condições, o máximo rendimento de hidrogênio. Entretanto, a aplicação de consórcios microbianos é mais interessante devido à maior gama de enzimas hidrolíticas e catabólicas disponíveis, de forma que o processo seja dinâmico, e, por conseguinte, levando à maior produção desse gás (CUI et al., 2009). Para a seleção do consórcio apropriado, pressão seletiva deve ser aplicada para favorecer o enriquecimento das populações de interesse (CARVER et al., 2012). Neste estudo, buscou-se selecionar um consórcio microbiano com características celulolíticas e fermentativas. 
Na fermentação acidogênica de compostos orgânicos são originados, além de hidrogênio, outros produtos de interesse biotecnológico, por exemplo, os ácidos orgânicos voláteis (AOVs), os quais também têm sido foco de pesquisa devido às diversas possibilidades de aplicações, principalmente na produção biológica de plásticos biodegradáveis (CAI et al., 2009) e bioenergia (UYAR et al., 2009; CHOI; CHANG; HAN, 2011). Os AOVs podem ser utilizados na produção de diferentes formas de energia, como por exemplo, a geração direta de eletricidade pelas células a combustível microbianas, além de serem usados como substrato para produção de metano, hidrogênio e biodiesel (LEE et al., 2014).

Para viabilizar economicamente a produção de bioenergia em escalas reais, a prioridade está na identificação de substratos apropriados, no que diz respeito à biodegradabilidade, ao teor de carboidratos, disponibilidade e baixo custo (URBANIEC; BAKKEN, 2015). Uma possibilidade é o uso de biomassa e resíduos urbanos e agroindustriais como fonte de energia renovável, que implica em uma das contribuições mais importantes para o desenvolvimento sustentável, já que a degradação biológica desses rejeitos orgânicos fornece subprodutos com valor agregado, como energia e biocombustíveis (ARANDA USÓN et al., 2012). Como muitos resíduos são constituídos de matéria orgânica complexa e/ou insolúvel, tais como celulose, hemicelulose entre outros, é importante avaliar a conversão desses substratos complexos em hidrogênio.

A celulose, por exemplo, contém elevado teor de energia química, é renovável e abundante como biomassa vegetal e em resíduos de papel. A celulose é constituída por subunidades de glicose, as quais, uma vez solubilizadas, são prontamente fermentáveis pelos micro-organismos. Outras fontes de biomassa contemplam madeira e seus resíduos, culturas agrícolas e seus resíduos, resíduos sólidos domésticos, como os resíduos de papel, esterco, resíduos alimentícios, plantas aquáticas e macroalgas, além de águas residuárias de processamento de biomassa (DEMIRBAS, 2001).

O papel residual ou de despejo é particularmente interessante como matéria-prima para produção de energia porque é prontamente disponível em abundância. Apesar da reciclagem, a maior parte do resíduo de papel, ainda acaba disposta em aterros sanitários (CHU; FENG, 2013; FRESCA, 2007). Portanto, é possível manter um constante fornecimento de grandes quantidades de resíduo de papel para a produção de energia.

O potencial de produção de energia na forma de hidrogênio, etanol e metano a partir de papel por meio de uma variedade de processos tem sido avaliado por muitos pesquisadores (BOTTA, 2012; CHAIRATTAMANOKORN et al., 2012; ELLISTON et 
al., 2013; WU; HUANG, SHIH, 2014; YEN, BRUNE, 2007). Entretanto, apesar de ser comprovada a possibilidade de geração de vetores energéticos a partir do papel, a hidrólise desta matéria-prima a açúcares fermentáveis ainda deve ser avaliada, levandose em conta, principalmente, a redução do custo e do potencial poluidor dos prétratamentos de hidrólise aplicados (hidrólise ácida e enzimática, por exemplo). A seleção de um consórcio microbiano celulolítico e fermentativo, porém não metanogênico, é um passo importante para viabilizar a utilização de resíduos celulósicos complexos como matéria-prima para produção de energia.

A motivação deste estudo decorre da necessidade de contribuir com uma sociedade sustentável, a qual requer a redução da dependência de combustíveis fósseis esgotáveis e a minimização da geração da poluição devido às atividades humanas, crescimento populacional e industrialização desordenada.

Desde 2012, no Brasil, foi promulgada a Lei no 12.305/10 que institui a Política Nacional de Resíduos Sólidos (PNRS). Por meio desta lei tem-se instrumentos para propiciar o incentivo à reciclagem e à reutilização dos resíduos sólidos, bem como a destinação ambientalmente adequada dos rejeitos não aproveitáveis. Além disso, foi instituída a responsabilidade dos geradores de resíduos pelo seu tratamento e disposição adequados. Neste contexto, pode-se a partir do uso de resíduos sólidos orgânicos, como o papel, produzir energia por meio de processos biológicos e atingir dois ganhos, simultaneamente: a redução do potencial poluidor dos resíduos, com minimização do impacto ambiental devido à sua disposição, e obtenção de energia renovável.

Para tanto, neste estudo buscou-se primeiramente obter um consórcio microbiano a partir do fluido de rúmen bovino, com atividade celulolítica e fermentativa, com a finalidade de promover a conversão de papel a compostos de interesse biotecnológico (hidrogênio, ácidos orgânicos e álcoois), na ausência da metanogênese. A partir dessa microbiota avaliou-se a fermentação acidogênica do papel fragmentado, sendo acondicionado em lisímetros de escala de bancada. Para tanto, testou-se 9 condições diferentes, considerando as variáveis temperatura, massa de papel adicionada e teor de umidade inicial do papel no modelo de planejamento experimental (DCC). Para se conhecer as populações microbianas presentes no fluido de rúmen original e após diluições seriadas para enriquecimento das populações de interesse, e ainda após a submissão à diferentes condições de operação nos lisímetros, uma análise aprofundada dos gêneros mais abundantes em cada amostra foi realizada após sequenciamento massivo via Plataforma Illumina. 


\section{OBJETIVO GERAL}

O objetivo desse trabalho foi avaliar a sacarificação e fermentação simultâneas de papel tipo sulfite, este usado como modelo de substrato celulósico, para produção de vetores energéticos e compostos orgânicos de interesse biotecnológico em lisímetros por meio de fermentação semissólida, com o uso de fluido de rúmen como fonte de inóculo.

Hipótese A: O rúmen bovino está entre os principais sistemas no que se refere à diversidade filogenética e fisiológica de micro-organismos atuantes no bioprocessamento da matéria orgânica celulósica. A fermentação de biomassa a hidrogênio e ácidos orgânicos voláteis ocorre naturalmente no rúmen. Assim, o uso desta fonte natural de micro-organismos celulolíticos permitiria a aplicação de um sistema engenheirado de sacarificação e fermentação simultâneas de papel, sem etapas prévias de hidrólise.

Objetivo específico: Obter um consórcio microbiano a partir do fluido de rúmen com características celulolítica e fermentativa e não metanogênico, por meio de diluições seriadas, para aplicá-lo como inóculo nos lisímetros.

Hipótese B: O design do processo depende principalmente das características do substrato, que restrigem a temperatura de operação (mesofílica ou termofílica), a configuração do reator, a massa de substrato (teor de sólidos) adicionada, além do teor de umidade. É sabido que este é um dos parâmetros mais importantes que influenciam toda a eficiência do processo hidrolítico e fermentativo. A hipótese é de que o lisímetro é uma possibilidade promissora para fermentação de resíduos sólidos e, dentre as condições estudadas, pode-se avaliar aquelas que favoreceram a fermentação do papel no lisímetro, operado com teor de umidade reduzido. A operação com umidade reduzida leva à redução do tamanho do reator e menor produção de percolado (efluente).

Objetivo específico: Avaliar as condições operacionais que promovam atividade fermentativa de papel em lisímetro, quanto à massa de substrato adicionada, teor de umidade do substrato, e temperatura de operação do sistema no modelo de Planejamento Experimental, tratando-se de um Delineamento Composto Central - Fatorial $2^{3}$. 
Hipótese C: A variação nas condições de operação dos lisímetros quanto ao teor de umidade, massa de papel adicionada e principalmente quanto à temperatura de incubação leva à obtenção de diferentes rendimentos de hidrogênio e outros subprodutos da fermentação, como os ácidos orgânicos e álcoois. As condições ambientais ou operacionais de um sistema engenheirado influenciam diretamente na estrutura da comunidade microbiana em um consórcio misto, com o favorecimento de algumas populações em detrimento de outras. $\mathrm{O}$ enriquecimento de populações celulolíticas e fermentativas do fluido de rúmen in natura, em detrimento das populações metanogênicas, levaria à uma alteração na diversidade e abundância das espécies do fluido original, pois este se tornou um consórcio essencialmente fermentativo e produtor de ácidos. Ademais, o aumento da temperatura de operação de 35 para 45 e $55^{\circ} \mathrm{C}$ leva à uma mudança notória na estrutura da comunidade microbiana comparada ao fluido de rúmen in natura e ao fluido de rúmen enriquecido, que de fato foi usado como inóculo em todos os lisímetros.

Objetivo específico: Identificação filogenética dos micro-organismos presentes na biomassa microbiana usada para inocular os lisímetros por sequenciamento massivo via Plataforma Illumina. 


\section{REVISÃO BIBLIOGRÁFICA}

\subsection{Produção biológica de hidrogênio, ácidos orgânicos e álcoois e os principais fatores da fermentação}

O hidrogênio molecular, potencial carreador energético, tornou-se substituinte promissor dos combustíveis fósseis. Do ponto de vista energético tem-se para o gás hidrogênio maior potencial de geração de energia dentre todos os combustíveis e/ou carreadores conhecidos, pode ser tanto usado para combustão direta, quanto para produção de energia elétrica por meio de células a combustível (GHIMIRE et al., 2015).

Do ponto de vista de sustentabilidade são diversas as vantagens de obtenção do hidrogênio. A primeira é que o elemento hidrogênio é o mais abundante do planeta, e pode ser facilmente obtido de fontes renováveis, fazendo-o um carreador de energia inesgotável. A segunda diz respeito à combustão de gás hidrogênio a qual libera apenas energia e vapor de água, o que contribui para reduzir a emissão de gases do efeito estufa (HAWKES et al., 2007).

A fermentação de compostos orgânicos é considerada a forma mais promissora para a geração de biohidrogênio devido à velocidade elevada de conversão de matéria orgânica à hidrogênio por uma microbiota fermentativa acidogênica (KAPDAN; KARGI, 2006). Entretanto, o desenvolvimento do processo fermentativo em escala industrial é ainda limitado devido ao baixo rendimento de produção de hidrogênio, quando comparado ao valor teórico máximo de $4 \mathrm{~mol}$ de $\mathrm{H}_{2}$ por mol de hexose. Devido a isso, cada vez mais, busca-se aprimorar este processo a fim de obter rendimentos satisfatórios de hidrogênio, a partir de melhorias em design e operação de biorreatores, seleção de inóculos e micro-organismos e viabilização de substratos para hidrólise e fermentação (GHIMIRE et al., 2015; KUMAR et al., 2015).

Além desses fatores que influenciam diretamente no rendimento de hidrogênio, outros fatores, tais como $\mathrm{pH}$, temperatura, taxa de carregamento orgânico, tempo de detenção hidráulico, suplementação com macro e micronutrientes e elementos traço, e pressão parcial de gases são extremamente importantes (GHIMIRE et al., 2015; WANG; WAN, 2009). As vias metabólicas desempenhadas pelos micro-organismos, que 
influencia no rendimento e na velocidade de produção de hidrogênio, são altamente dependentes desses fatores.

A fermentação de compostos orgânicos complexos pela microbiota anaeróbia mista pode resultar em ampla variedade de compostos intermediários e metabólitos, dependendo das condições operacionais, uma vez que estas também afetam diretamente a estrutura das comunidades microbianas dos biorreatores. Na fermentação mista, a hexose é convertida a piruvato pela via glicolítica, com produção de adenosina trifosfato (ATP) a partir de adenosina difosfato (ADP) e nicotinamida-adenina-dinucleotídeo $(\mathrm{NADH})$ reduzida. O piruvato é então oxidado a acetil-coenzima $\mathrm{A}$ (acetil-coA), $\mathrm{CO}_{2} \mathrm{e}$ $\mathrm{H}_{2}$ pelas enzimas piruvato ferredoxina oxido-redutase e hidrogenase. Dependendo das populações microbianas e condições impostas, piruvato pode ser também convertido a acetil-CoA e formiato, posteriormente convertido a $\mathrm{CO}_{2}$ e $\mathrm{H}_{2}$ (8). Além disso, a acetilCoA é ainda convertida a ácido acético, ácido butírico e etanol. Outros compostos como ácido láctico, ácido propiônico, metanol e n-butanol podem também serem produzidos, e, de acordo com a concentração de cada composto, há variação no rendimento final de hidrogênio (SAADY, 2013). (Figura 3.1)

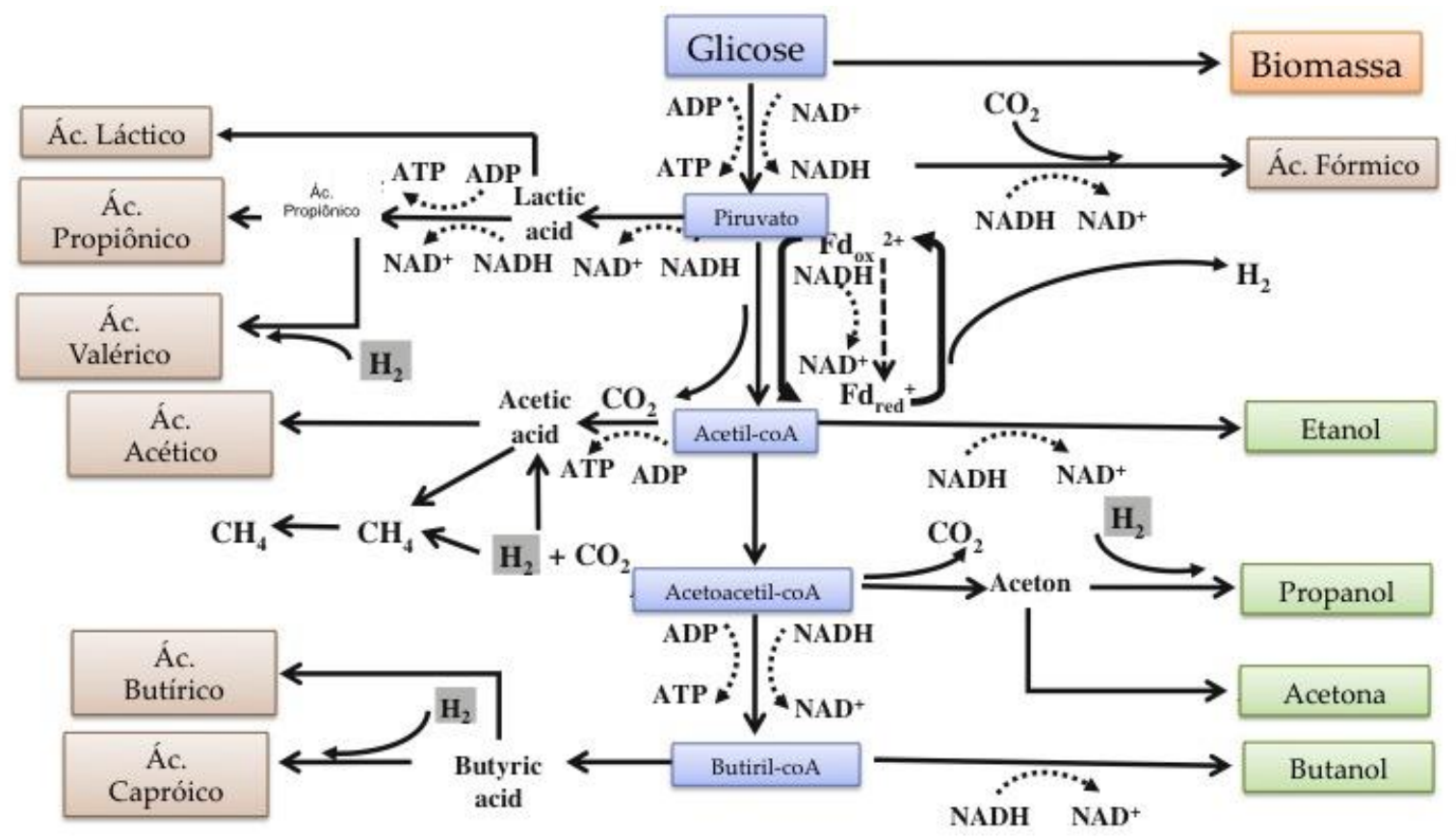

Figura 3.1 - Fluxograma de reações metabólicas da fermentação mista Fonte: adaptado de Saady (2013). 
Estes metabolismos bioquímicos podem ser mediados por bactérias anaeróbias estritas, como Clostridium e bactérias do rúmen, por exemplo, e bactérias facultativas como Escherichia coli e Enterobacter. Em temperatura termofílica, o gênero que se destaca para fermentação e produção de hidrogênio é o Thermoanaerobacterium. Culturas mistas de bactérias produtoras de hidrogênio são preferenciais em relação à culturas puras devido à sua maior praticabilidade em aumento de escala, menor custo de operação, já que economiza o custo de assepsia, maior facilidade de controle baseado nas diferentes cinéticas de crescimento dos micro-organismos e ampla possibilidade de substratos (GHIMIRE et al., 2015; NTAIKOU; LYBERATOS, 2010). Entretanto, o enriquecimento dessas culturas com favorecimento das populações fermentativas e inibição das populações consumidoras de hidrogênio faz-se necessária para a aplicação em reatores de produção de hidrogênio.

Os parâmetros pH e temperatura de operação são os mais cruciais na determinação de vias metabólicas ótimas para síntese de hidrogênio e ácidos orgânicos e inibição de metabolismos de consumo deste gás, os quais podem ocorrer simultaneamente (GHIMIRE et al., 2015; KHANAL et al., 2003). A operação em pH na faixa ácida inibe principalmente a atividade metanogênica, tanto em temperatura mesofílica, quanto na termofílica. Todavia, Luo et al. (2011) verificaram que a inibição da homoacetogênese, por exemplo, foi observada apenas em condição termofílica sob $\mathrm{pH}$ inicial 5,5. Estes autores detectaram consumo de hidrogênio usando inóculo pré-tratado, após longo período de sucessivas bateladas sequencias e atribuíram este consumo à homoacetogênese.

$\mathrm{O}$ pH é um dos parâmetros chave que influencia nas rotas metabólicas dos microorganismos por afetar diretamente a atividade da enzima hidrogenase, enzima muito importante no processo de fermentação acidogênica. Na maioria dos estudos com fermentação acidogênica, ácido acético e ácido butírico são os compostos mais favoráveis para a síntese de hidrogênio. Khanal et al. (2003) concluíram que os níveis de produção de ácido acético e ácido butírico foram independentes do $\mathrm{pH}$ inicial dentro da faixa de 4,5-7,5.

Similarmente, Luo et al. (2011) reportaram maior produção de ácido butírico a partir da vinhaça de mandioca em $\mathrm{pH}$ inicial 5 e 7 . Aparentemente, a faixa ótima de $\mathrm{pH}$ para favorecer a produção de hidrogênio deve estar mais relacionada à fonte e métodos de enriquecimento do inóculo, tipos de substratos, entre outros fatores (WANG, WAN, 2009). Em condições de baixos valores de pH tem-se maior inibição da metanogênese, 
entretanto, sob tais condições pode ocasionar variação dos metabólitos resultantes e no rendimento de biohidrogênio.

A temperatura também tem sido um parâmetro estudado pela influência nas rotas metabólicas dos micro-organismos, alterando a composição de metabólitos da fermentação acidogênica. Em temperaturas mais elevadas pode-se favorecer a fermentação de compostos ricos em celulose e hemicelulose, já que afeta as taxas de hidrólise, pois a atividade hidrolítica é maior em micro-organismos termofílicos comparado aos mesofílicos (CHOU et al., 2008). Em estudos com resíduos de atividade agrícola foi observado maior produção de biohidrogênio a partir de palha de trigo, usando temperatura hipertermofílica. Neste estudo especificamente, o maior rendimento de hidrogênio foi de $212 \mathrm{~mL} \mathrm{H}_{2} / \mathrm{g}$ de açúcares, correspondendo a taxa de produção de 821,4 $\mathrm{mL} \mathrm{H}_{2} / \mathrm{d}$.L em reator UASB alimentado com palha de trigo hidrolisada sob TDH de 1 dia (KONGIAN, ANGELIDAKI, 2010).

O design do processo para fermentação acidogênica depende principalmente do substrato o qual limita as condições operacionais dos biorreatores, tais como a configuração do reator (tipos de reator), condição da fermentação (submersa, semissólida e sólida) e alimentação (adição de cossubstratos, por exemplo). Deve-se destacar também a possibilidade da aplicação de processos com elevado teor de sólido como a fermentação em condições semissólida (10-20\% sólidos totais) ou sólida (> 20\% sólidos totais) para produção de biohidrogênio, já que a conversão de resíduos e biomassa de segunda geração (principalmente resíduos agroindustriais) em energia é economicamente favorável (MOTTE et al., 2013). A aplicação da fermentação semissólida para produção de hidrogênio a partir de resíduos sólidos celulolósicos como substrato orgânico ainda é escassa, principalmente testando-se baixo teor de umidade.

O lisímetro é um biorreator que pode ser preenchido por matéria orgânica sólida ou semissólida, a fim de se buscar a digestão anaeróbia dessa biomassa com recuperação de energia, com baixo custo operacional (BALDOCHI, 1997; LEITE et al., 2009).

A utilização de lisímetros para avaliar o potencial fermentativo acidogênico da microbiota purificada do rúmen, a partir da conversão do papel em condições de umidade reduzida, foi avaliada após uma análise de estudos prévios em que foi obtido metano a partir da estabilização de resíduos sólidos domésticos na mesma configuração de reator (BALDOCHI, 1997; LOPES; LEITE, PRASAD, 2004).

Por meio da aplicação dos lisímetros tem-se como vantagens a possibilidade de suportar elevado teor de sólidos e baixos requerimentos de água e energia, com elevados 
rendimentos de metano, como observado por Baldochi (1997). Entretanto, entre as limitações estão período prolongado de start-up e acúmulo de ácidos orgânicos voláteis em operações de longo termo, devido à baixa diluição dos resíduos (BALDOCHI, 1997).

São muitos os fatores que influenciam o processo de digestão anaeróbia de resíduos sólidos orgânicos como o teor de umidade, a carga orgânica aplicada, peso específico dos resíduos, tempo de operação do biorreator, temperatura, tipo de inóculo, entre outros (LOPES; LEITE, PRASAD, 2004).

Lay, Lee e Noike (1999) estudaram a relação alimento/microrganismo (A/M) na produção de hidrogênio em reatores em batelada, usando a fração orgânica dos resíduos sólidos domésticos como substrato e duas fontes diferentes de inóculo: um inóculo foi obtido de um reator de produção de hidrogênio com cultura mantida em pH 5,0. O outro inóculo foi lodo submetido à tratamento térmico após coleta em digestor de resíduos sólidos metanogênico. Os autores descreveram que para o inóculo pré-tratado foi observado elevada atividade de produção de hidrogênio (45 mL/g SSV/h) a partir de uma relação A/M elevada (20 g sólidos/ 50 g lodo), entretanto, para o inóculo originalmente produtor de hidrogênio, a maior atividade $(36 \mathrm{~mL} / \mathrm{g} \mathrm{SSV} / \mathrm{h})$ foi detectada para relação $\mathrm{A} / \mathrm{M}$ baixa (5 g sólidos/ $50 \mathrm{~g}$ inóculo produtor $\mathrm{H}_{2}$ ). São escassos na literatura os estudos sobre a melhor concentração de resíduos sólidos celulósicos para a produção de hidrogênio, o que reforça o interesse em avaliar este parâmetro.

A presença de água favorece a condução de enzimas e de outros metabólitos microbianos contribuindo, dessa forma, para o metabolismo dos micro-organismos e, portanto destaca-se como fator de importância na otimização da relação custo/benefício dos processos de tratamento de resíduos sólidos orgânicos. Na natureza, o teor de umidade dos resíduos sólidos urbanos é decorrente da decomposição da fração orgânica, das condições climáticas e do tipo de coleta (TCHOBANOGLOUS; THEISEN, VIGIL, 1993). De acordo com Leite et al. (2009), a composição média do teor de umidade de certos tipos de resíduos, é quantitativamente mais representativo nos resíduos alimentícios e de papel.

Em 1977, Chian relatou que elevado grau de umidade dos resíduos sólidos favoreceria a fermentação ácida da matéria orgânica, levando à produção de hidrogênio e ácidos orgânicos voláteis. Entretanto, verificou-se que o teor de umidade de substratos sólidos orgânicos foi avaliado especificamente para a produção de metano (BALDOCHI, 1997; LEITE et al., 2009; LOPES; LEITE, PRASAD, 2004). 
Leite et al. (2009) estudaram o tratamento anaeróbio de resíduos sólidos orgânicos, composto de resíduos vegetais, em duas condições de concentração de sólidos: alta (20\% sólidos totais/ $80 \%$ umidade) e baixa (5\% sólidos totais/ $95 \%$ umidade). Verificou-se que para a condição de concentração de sólidos baixa, o tempo de retenção para redução em $80 \%$ da massa de DQO aplicada foi três vezes menor do que para a condição de concentração de sólidos alta (90 e 270 dias). Além disso, a produção de metano foi mais elevada para a concentração de sólidos alta $\left(0,25 \mathrm{Nm}^{3} \mathrm{CH}_{4} / \mathrm{kg}\right.$ DQO aplicada) em relação a baixa $\left(0,10 \mathrm{Nm}^{3} \mathrm{CH}_{4} / \mathrm{kg}\right.$ DQO aplicada). Por meio desses resultados pode-se destacar a importância do teor de umidade do substrato para a degradação do substrato sólido e recuperação de energia.

Fazendo-se o uso de resíduos agroindustriais (70\% bagaço de cana, 15\% casca de abacaxi e 15\% de lodo de biodigestor), sob condição mesofílica, Robledo-Narváez et al. (2013) relataram decréscimo do rendimento de hidrogênio quando o teor de sólidos totais no sistema foi acima de 18\%. MOTTE e colaboradores (2013) reportaram que o percentual de $19 \%$ de sólidos totais foi o limite para alcançar produção de hidrogênio durante a fermentação de palha de trigo, já que acima deste valor, as vias metabólicas foram alteradas para produção de ácido lático.

Nesse contexto, já que o teor de umidade do substrato é um fator de importância na degradação da matéria orgânica sólida, torna-se importante determinar quais são as melhores condições de umidade para se obter rendimentos de hidrogênio satisfatórios a partir da degradação de resíduos de papel.

A fração orgânica dos resíduos sólidos municipais ainda compreende percentual de papel considerável, o qual contém teor de umidade em torno de 70-80\%, em países subdesenvolvidos (ALVARADO et al., 2013). A aplicação desta fração como substrato para a produção de biocombustíveis tem sido estudada principalmente em baixa concentração de sólidos (10\% sólidos totais) ou "fermentação submersa". É notável que na "fermentação submersa" emprega-se elevados volumes de água para diluição dos sólidos, gerando grande volume de água residuária. Embora, menos estudada, a fermentação de substrato sólido, com teor de umidade controlado, tem vantagens como redução do volume de reator e diminuição da geração de lixiviado (ALVARADO et al., 2013).

Nesse contexto, já que o teor de umidade do substrato é um fator de importância na degradação da matéria orgânica sólida, foi considerado importante determinar quais são as melhores condições de umidade, evitando elevadas diluições de sólidos, para se 
obter rendimentos de hidrogênio satisfatórios a partir da degradação de resíduos sólidos celulósicos.

Este trabalho trata-se de um estudo inicial para a determinação dos melhores parâmetros relacionados à operação de um lisímetro como configuração de reator (BALDOCHI, 1997) para a produção de hidrogênio, ácidos orgânicos e outras formas de energia a partir de resíduos sólidos celulósicos. Para tanto, foi utilizado o papel de escritório limpo como substrato orgânico, já que este contém elevado teor de celulose (BOTTA, 2012; NTAIKOU; KOUTROS, KORNAROS, 2009). O interesse foi obter dados preliminares para uma pesquisa futura com resíduos de papel e/ou resíduos da indústria de papel e celulose, como a polpa, assim como já foram realizados testes com substratos ideais, tais como a glicose e sacarose entre outros para o estudo em biorreatores (BARROS et al., 2010; PENTEADO et al., 2013).

\subsection{Produção de energia sustentável a partir de resíduos celulósicos}

A atual crise energética mundial deriva, em grande parte, da dependência da economia global pelos combustíveis fósseis não renováveis como principal fonte de energia, os quais são utilizados de maneira crescente e tendem a se esgotar. Os biocombustíveis são o novo foco na busca por vias alternativas de produção de energia pelo potencial de reduzir a dependência aos combustíveis fósseis, a emissão de gases estufa e facilitar a distribuição de energia em muitos países (QUEK; BALASUBRAMANIAN, 2014).

Os biocombustíveis englobam todo o tipo de combustível derivado de biomassa, incluindo biomassa sólida, combustíveis líquidos e biogás. A produção de biocombustíveis a partir de fontes renováveis já é uma realidade. Entretanto, a produção de combustíveis de primeira geração, obtida principalmente a partir de vegetais alimentícios, acarreta questionamentos no que concerne a sustentabilidade dessa bioenergia. Tais preocupações giram em torno do efeito nos preços globais de alimento e da segurança no abastecimento de alimentos, cuja produção pode ser afetada, o que acaba resultando em uso limitado de biocombustíveis (ESCOBAR et al., 2009; SHEEHAN, 2009).

Levando-se em conta a competição com a produção de alimento, somada à questões econômicas e de preservação ambiental é apropriado o uso de matérias-primas 
residuais como fonte energética para a produção dos chamados biocombustíveis de segunda geração.

Os estudos sobre gerenciamento de energia e resíduos ganham atenção especial principalmente devido à disponibilidade limitada de terra e recursos, além de problemas relacionados com poluição (UDOMSRI et al., 2011). A recuperação da energia é uma questão essencial do manejo moderno de resíduos, já que a degradação biológica da fração residual pode fornecer subprodutos com valor agregado, como energia e biocombustíveis (ARANDA USÓN et al., 2012).

Há demanda por novas fontes de matérias primas para a produção biotecnológica de combustíveis. Sabe-se que muitos resíduos provenientes de atividades urbanas e agrícolas e de processos industriais são considerados fonte potencial de energia limpa e renovável. São consideradas matérias-primas promissoras os resíduos sólidos domésticos (RSD), além de materiais lignocelulósicos, como substrato para a produção de açúcares fermentáveis, tanto pela elevada disponibilidade, quanto pelo baixo custo de obtenção. Entre os materiais lignocelulósicos estão, por exemplo, palha, serragem, bagaço, ripas de madeira, gramas, resíduos da atividade ou culturas agrícolas, RSD e resíduos de papel (BRUMMER et al., 2014; WU; HUANG, SHIH, 2014).

Celulose, hemicelulose e lignina, que são os principais componentes da biomassa lignocelulósica, interagem entre si para formar uma estrutura rígida que dificulta a sua degradação. A celulose é o polímero mais abundante na natureza e tem grande importância no ciclo global do carbono, e, por meio da sua hidrólise e fermentação temse a liberação de compostos de interesse (NTAIKOU; LYBERATOS, 2010).

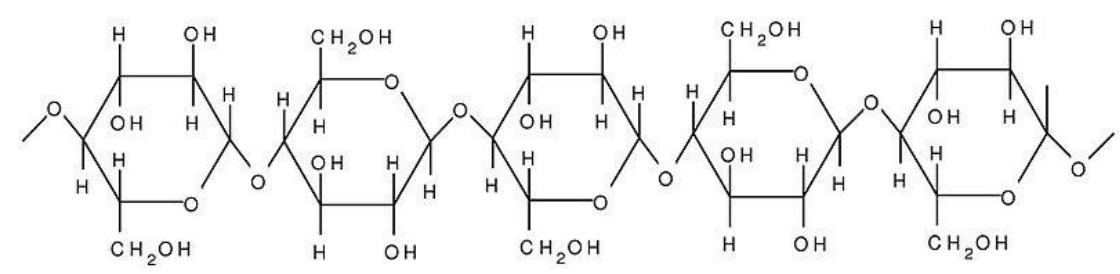

Figura 3.2 - Fórmula estrutural da celulose: polímero formado por monômeros de glicose interligados pela ligação Fonte: Easychem (2016).

\section{$\beta-1,4$ glicosídica}

Na biomassa lignocelulósica, a celulose é geralmente a maior fração, entre 40$50 \%$ do peso, e hemicelulose, entre 20-40\% (MCKENDRY, 2002; SAXENA; 
ADHIKARI, GOYAL, 2009). As proporções de celulose e lignina são importantes nos processos bioquímicos de conversão de biomassa para geração de energia. A biodegradabilidade da celulose é maior do que a da lignina, portanto para materiais que contenham maior proporção de celulose, a conversão do carbono em energia é mais rápida e maior (MCKENDRY, 2002).

O bagaço da cana-de-açúcar, por exemplo, contém as seguintes proporções de celulose (40-50\%), hemicelulose (20-30\%), lignina (20-25\%) e cinzas (1,5-3\%) (SAXENA; ADHIKARI, GOYAL, 2009). A palha de trigo contém de 33-40\% de celulose, de 20-25\% de hemicelulose e de 15-20\% de lignina (McKENDRY, 2002). Levando-se em conta a relação celulose/lignina tem-se algumas vantagens operacionais quando se tratam de resíduos de papel já que o processamento da polpa, por meio de tratamentos mecânicos e químicos, efetivamente delignifica e remove significativamente a hemicelulose, tornando o papel mais facilmente biodegradável (WU et al., 2014; NTAIKOU; KOUTROS, KORNAROS, 2009). Na Tabela 3.1 está descrita a composição de alguns tipos de papel (resultados apresentados como porcentagens de peso seco) usados para a produção de bioetanol (WANG et al., 2013).

Tabela 3.1 - Composição dos resíduos de papel

\begin{tabular}{ccccc}
\hline Componentes* & Papel Jornal & Papel escritório & Papel Revista & Papel Cartão \\
\hline Glicose & $47,20(0,05)$ & $58,64(0,05)$ & $35,91(0,08)$ & $52,61(0,06)$ \\
Xilose & $7,11(0,02)$ & $14,65(0,08)$ & $4,72(0,06)$ & $8,23(0,06)$ \\
Galactose & $1,90(0,02)$ & $0,00^{\mathrm{a}}$ & $1,98(0,02)$ & $1,89(0,01)$ \\
Manose & $7,31(0,01)$ & 0,00 & $5,67(0,04)$ & $5,07(0,01)$ \\
Arabinose & $1,86(0,07)$ & 0,00 & $1,82(0,03)$ & $1,55(0,03)$ \\
Carboidratos & 65,38 & 73,29 & 50,10 & 69,35 \\
totais & 18,14 & 6,09 & 14,83 & 15,77 \\
Lignina & $2,13(0,04)$ & $8,12(0,02)$ & $2,63(0,04)$ & $4,20(0,01)$ \\
CaCO 3 & & & & Continua
\end{tabular}


continuação

\begin{tabular}{ccccc}
\hline Componentes* & Papel Jornal & Papel escritório & Papel Revista & Papel Cartão \\
& & & & \\
\hline Cinzas & $10,51(0,11)$ & $7,97(0,08)$ & $30,14(0,16)$ & $9,89(0,07)$ \\
Massa Total & 100,09 & 97,44 & 101,15 & 101,76
\end{tabular}
papel.

Tabela adaptada de Wang et al. (2013) para exemplificar a composição de diferentes tipos de

*Porcentagem de peso seco

${ }^{\text {a }}$ Zero representa a quantidade traço abaixo do limite de detecção do método no HPLC.

${ }^{\mathrm{b}} \mathrm{A}$ massa total acima de $100 \%$ é devido à variação intrínseca das médias dos componentes.

Os valores nos parênteses representam o desvio padrão da triplicata de amostras

Na literatura consta cada vez mais estudos sobre a hidrólise de resíduos de papel e sua conversão em bioenergia por processos bioquímicos. De acordo com alguns destes estudos, foi mencionado que para resíduos de papel não é necessário pré-tratamentos termofísicos energicamente dispendiosos ou tratamento ácido intenso seguido de hidrólise enzimática, geralmente usada na sacarificação de outros resíduos lignocelulósicos (WANG et al., 2013). Além disso, o papel contém níveis elevados de carboidratos que podem ser convertidos a biocombustíveis (NTAIKOU; KOUTROS, KORNAROS, 2009; WANG et al., 2013). O crescente número de estudos com resíduos de papel reforça o potencial desse material como recurso renovável para a produção sustentável de energia na forma líquida ou gasosa (WANG TEMPLER, MURPHY, 2012; WANG et al. 2013; WU; HUANG, SHIH, 2014).

O uso alternativo de papel para produção de hidrogênio já foi investigado, usandose variedade de processos, tais como, contínuo (CHAIRATTAMANOKORN et al., 2012) ou em batelada (BOTTA, 2012), com culturas puras (NTAIKOU; KOUTROS, KORNAROS, 2009) ou consórcios microbianos (VALDEZ-VAZQUEZ et al., 2005), em temperatura mesofílica ou termofílica (VALDEZ-VAZQUEZ et al., 2005; KÁDAR; SZENGYEL, RECZEY, 2004a), e fazendo-se o uso (BOTTA, 2012) ou não (NTAIKOU; KOUTROS, KORNAROS, 2009) de pré-tratamentos para sacarificação de papel.

Botta (2012) obteve rendimentos satisfatórios de hidrogênio usando papel hidrolisado como substrato em experimentos em reator em batelada, especialmente para 0,5 g/L de papel (42 mmol $\mathrm{H}_{2} / \mathrm{g}$ papel). Neste estudo, a fermentação de oligossacarídeos solúveis resultantes da quebra do papel por consórcio microbiano purificado do fluido 
ruminal ocorreu simultaneamente à hidrólise enzimática pela celulase exógena adicionada ao sistema, o que provavelmente levou aos elevados rendimentos.

Chairattanamanokorn et al. (2012) objetivaram investigar a proporção ideal de polpa celulósica e papel de escritório residual para a produção de hidrogênio em reator em batelada por lodo anaeróbio previamente submetido a tratamento térmico. Os substratos foram submetidos à pré-tratamento alcalino e, posteriormente, à hidrólise enzimática com celulase bruta. Os resíduos de papel foram adicionados para compensar o baixo teor de carbono presente na polpa, e foi descrito que pequena porcentagem de papel favoreceu significativamente a produção acumulada de hidrogênio. Os autores obtiveram maior produção de hidrogênio $\left(146,84 \pm 1,84 \mathrm{~mL} \mathrm{H}_{2} / \mathrm{L}\right)$ para relação resíduo/polpa de 1:3, sendo que a pior produção $\left(26,81 \pm 9,66 \mathrm{~mL} \mathrm{H}_{2} / \mathrm{L}\right)$ foi detectada para a condição em que não foi adicionado o resíduo de papel.

A degradação seguida de consumo expressivo de resíduos de papel, sem tratamento prévio, com produção de hidrogênio foi relatada por Ntaikou, Koutros e Kornaros (2009). Os autores descreveram elevado teor de carboidrato fermentável em diferentes resíduos de papel e a conversão desses carboidratos por Ruminococcus albus, com melhor eficiência para papel higiênico e papel de escritório (Tabela 3.2). O elevado consumo de carboidratos para alguns resíduos de papel ilustra a elevada biodegradabilidade desse material.

Tabela 3.2 - Caracterização dos diferentes tipos de papel, consumo total de carboidratos e rendimentos de hidrogênio

\begin{tabular}{cccccc}
\hline $\begin{array}{c}\text { Resíduo } \\
\text { Papel }\end{array}$ & $\begin{array}{c}\text { Carboidratos } \\
\text { Totais }\end{array}$ & $\begin{array}{c}\text { Carboidratos } \\
\text { Solúveis }\end{array}$ & $\begin{array}{c}\text { Consumo } \\
\text { carboidratos } \\
(\%)\end{array}$ & $\begin{array}{c}\text { Rendimento } \\
\mathrm{H}_{2}(\mathrm{~mol} / \mathrm{mol} \\
\text { carboidrato } \\
\text { consumido })\end{array}$ & $\begin{array}{c}\text { Rendimento } \mathrm{H}_{2} \\
\left(\mathrm{~L} \mathrm{H} \mathrm{H}_{2} / \mathrm{kg}\right. \\
\text { papel })\end{array}$ \\
\hline $\begin{array}{c}\text { Papel } \\
\text { Higiênico }\end{array}$ & $99,45 \pm 0,05$ & $1,89 \pm 0,01$ & $100 \pm 0,0$ & $2,18 \pm 0,11$ & $282,76 \pm 1,46$ \\
Papel & & & & & \\
escritório & $86,11 \pm 0,18$ & $3,38 \pm 0,01$ & $100 \pm 0,0$ & $2,27 \pm 0,08$ & $242,83 \pm 1,01$
\end{tabular}


continuação

\begin{tabular}{|c|c|c|c|c|c|}
\hline $\begin{array}{c}\text { Resíduo } \\
\text { Papel }\end{array}$ & $\begin{array}{c}\text { Carboidratos } \\
\text { Totais } \\
(\%)\end{array}$ & $\begin{array}{c}\text { Carboidratos } \\
\text { Solúveis } \\
(\%)\end{array}$ & $\begin{array}{c}\text { Consumo } \\
\text { carboidratos } \\
(\%)\end{array}$ & $\begin{array}{l}\text { Rendimento } \\
\mathrm{H}_{2} \text { (mol/mol } \\
\text { carboidrato } \\
\text { consumido) }\end{array}$ & $\begin{array}{c}\text { Rendimento } \mathrm{H}_{2} \\
\text { ( } \mathrm{L} \mathrm{H}_{2} / \mathrm{kg} \\
\text { papel })\end{array}$ \\
\hline Revista & $50,03 \pm 1,01$ & $2,07 \pm 0,01$ & $66,14 \pm 1,36$ & $2,29 \pm 0,12$ & $94,22 \pm 1,93$ \\
\hline Papelão & $73,46 \pm 093$ & $8,46 \pm 0,01$ & $87,97 \pm 11,83$ & $1,72 \pm 0,23$ & $137,78 \pm 18,53$ \\
\hline Jornal & $65,31 \pm 0,65$ & $1,12 \pm 0,01$ & $18,26 \pm 3,12$ & $2,89 \pm 0,51$ & $42,81 \pm 7,32$ \\
\hline $\begin{array}{l}\text { Glicose } \\
\text { (controle) }\end{array}$ & - & - & $100 \pm 0,0$ & $2,20 \pm 0,12$ & - \\
\hline
\end{tabular}

Fonte: Adaptada de Ntaikou, Koutros e Kornaros (2009).

Ademais, tem-se para alguns estudos o uso de resíduos de papel para a produção de bioetanol. A sacarificação e fermentação simultânea de papel cartão (KADAR et al., 2004b), papel de jornal (BRUMMER et al., 2014; PARK et al., 2010; WU et al., 2014), e papel de escritório (ELLISTON et al., 2013; SANGKHARAK, 2011) para a produção de etanol são alguns exemplos desses estudos.

Wu, Huang e Shih (2014) relataram conversão de 96\% (5,72 g/L etanol) de hidrolisado de papel (11,8 g/L açúcares fermentáveis). De acordo com Shi, Koh e Tan (2009), foi estimado que aproximadamente 83 bilhões de litros de bioetanol derivados do papel podem ser produzidos por ano no mundo, o que pode substituir em até 5,36\% do consumo de gasolina e reduzir em até $86 \%$ a emissão de gases de efeito estufa. Isso reforça a possibilidade do uso do papel como substrato para produção de biocombustíveis.

Neste contexto, esta proposta trata-se de um estudo para se determinar os melhores parâmetros operacionais de um lisímetro como configuração de reator para a produção de biocombustíveis gasosos e/ou líquidos a partir de um resíduo lignocelulósico em potencial.

Diferentemente da maioria dos outros estudos, esta proposta teve como objetivo alcançar a hidrólise e fermentação simultânea de papel sem tratamento prévio, usando consórcio microbiano celulolítico e fermentativo obtido do fluido de rúmen bovino. Por meio da realização deste estudo foi possível também identificar as bactérias do consórcio 
microbiano purificado do fluido de rúmen, que estiveram, provavelmente, envolvidas na sacarificação e fermentação de papel nas diferentes condições operacionais.

\subsection{Degradação da celulose com fluido de rúmen como fonte de micro-organismos celulolíticos e fermentativos}

Apesar da natureza biologicamente recalcitrante da biomassa lignocelulósica, essa

pode ser digerida eficientemente por micro-organismos em ecossistemas naturais, disponibilizando compostos orgânicos de mais fácil assimilação (YUE et al., 2013).

A degradação de celulose pode ser realizada fisiologicamente por diversos táxons de micro-organismos, dentre eles bactérias e fungos aeróbios e anaeróbios. Dentre os micro-organismos aeróbios capazes de degradar a celulose estão os gêneros Acidothermus, Bacillus, Caldibacillus, Cellulomonas, Cellvibrio, Cytophaga, Dyella, Erwinia, Microbacterium, Micromonospora, Pseudomonas, Pseudoxanthomonas, Sporocytophaga, Rhodothermus, Streptomyces e Thermobifida. Já os celulolíticos anaeróbios pertencem aos gêneros Acetivibrio, Anaerocellum, Bacterioides, Butyvibrio, Caldicelluloseruptor, Clostridium, Desulforoccus, Enterococcus, Eubacterium, Fibrobacter, Halocella, Ruminococcus, Spirochaeta e Thermotoga (TSAVKELOVA, NETRUSOV, 2012).

A hidrólise de celulose rende glicose, celobiose e celodextrinas (LYND et al., 2002). No metabolismo anaeróbio, os produtos de fermentação da celulose e açúcares intermediários contêm quantidades significantes de hidrogênio, dióxido de carbono e ácido acético. A conversão de intermediários, como o ácido pirúvico, por exemplo, rende ácido láctico, etanol, ácido fórmico, ácido succínico, além de outros ácidos orgânicos, hidrogênio e dióxido de carbono por ampla diversidade de bactérias (LYND; WYMAN, GERNGROSS, 1999).

A degradação de celulose em ambientes naturais se dá por consórcios microbianos que incluem espécies celulolíticas e não celulolíticas, que além das interações catabólicas, se relacionam sintroficamente, suprindo com fixação de nitrogênio, vitaminas e outros fatores de crescimento essenciais para os membros da comunidade (TSAVKELOVA; NETRUSOV, 2012).

A velocidade de hidrólise de celulose depende principalmente da atividade dos membros da comunidade microbiana. Comunidades mistas são mais eficientes do que 
culturas mesofílicas puras de Clostridium cellulolyticum ou Ruminococcus albus, por exemplo (DESVAUX; GUEDON, PETITDEMANGE, 2001; SONG; CLARKE, 2009). A origem da comunidade microbiana e a quantidade de incóculo são de importância especial, já que afetam a densidade de colonização e a adesão nas fibras de celulose (SONG, CLARKE, 2009). As comunidades intestinais, por exemplo, são responsáveis por uma das taxas mais rápidas de bioconversão microbiana de lignocelulose na natureza, portanto há um interesse considerável no potencial biotecnológico das bactérias do rúmen, bem como em suas enzimas e sistemas enzimáticos, para o uso na produção de energia a partir de compostos celulósicos renováveis (LYND et al., 2002).

O rúmen é um ecossistema anaeróbio complexo em que a digestão da matéria lignocelulósica ingerida por animais ruminantes ocorre por microflora anaeróbia ativa e altamente diversificada fisiológica e filogeneticamente. Os micro-organismos do rúmen têm sido empregados com sucesso na digestão de uma variedade de compostos lignocelulósicos, incluindo resíduos de agricultura, fração orgânica dos resíduos sólidos urbanos e plantas aquáticas (BARNES; KELLER, 2004; HU; YU, 2005; YUE; BRUNE, 2007). Acredita-se que as três espécies celulolíticas Ruminococcus flavifaciens, Ruminococcus albus e Fibrobacter succinogenes sejam os agentes primários da digestão anaeróbia no rúmen (PETTIPHER; LATHAM, 1979; WEIMER, 1996).

As bactérias geralmente hidrolisam celulose em baixa velocidade, mas consórcios microbianos presentes no rúmen hidrolisam de 60 a $65 \%$ de celulose em 48 horas (SCHWARZ, 2001). De acordo com Weimer (1996), a velocidade de hidrólise de celulolse para essas três espécies celulolíticas é mais elevada do que para a maioria das espécies celulolíticas não-ruminais, incluindo algumas espécies de fungo utilizadas para produção comercial de celulases (Trichoderma reesei), com exceção da bactéria termofílica Clostridium thermocellum (Tabela .3). 
Tabela 3.3 - Constante cinética de hidrólise de celulose por micro-organismos ruminais e não-ruminais

\begin{tabular}{|c|c|c|c|}
\hline Organismo & Fonte & Substrato & $\begin{array}{c}\text { Constante cinética } \\
\text { de hidrólise } \\
\left(h^{-1}\right)\end{array}$ \\
\hline $\begin{array}{l}\text { Clostridium } \\
\text { thermocellum }\end{array}$ & Não-ruminal & $\mathrm{AV}$ & 0,16 \\
\hline Ruminococcus flavifaciens & Ruminal & $\mathrm{SC}$ & 0,08 \\
\hline Fibrobacter succinogenes & Ruminal & $\mathrm{SC}$ & 0,07 \\
\hline Ruminococcus albus & Ruminal & AV & 0,05 \\
\hline Cellulomonas uda & Não-ruminal & $\mathrm{AV}$ & 0,027 \\
\hline Cellulomonas flavigena & Não-ruminal & AV & 0,006 \\
\hline $\begin{array}{l}\text { Fungos "White-rot" } \\
\text { (5 espécies) }\end{array}$ & Não-ruminal & Cot & $<0,004$ \\
\hline $\begin{array}{l}\text { Fungos "Brown-rot" } \\
\text { (8 espécies) }\end{array}$ & Não-ruminal & Cot & $<0,002$ \\
\hline
\end{tabular}

Um aspecto importante das bactérias celulolíticas anaeróbias é a sua capacidade de adesão ao substrato. Essa adesão é mediada pela matriz extracelular bacteriana, que além de promover o ancoramento dos micro-organismos ao substrato a ser hidrolisado, forma uma proteção contra uma variedade de fatores físico-químicos (LYND et al., 2002). As bactérias celulolíticas do rúmen caracterizam-se pela aderência das suas células à superfície da celulose; retenção de enzimas celulolíticas na superfície da membrana celular; e degradação da celulose cristalina (WEIMER, 1996). Verificou-se adesão muito mais rápida de micro-organismos do rúmen em partículas de celulose em comparação com micro-organismos de lixiviado de reator anaeróbio municipal (O'SULLIVAN; BURRELL, PASMORE, 2009; SONG; CLARKE, BLACKALL, 2005). Por meio de imagens de microscopia electrônica, verificou-se que micro-organismos do rúmen formam um biofilme denso e estável, com produção eficiente de complexos enzimáticos (O’SULLIVAN; BURRELL, PASMORE, 2009).

A vantagem mais atrativa da inoculação de reatores com fluido de rúmen é a introdução certeira de micro-organismos responsáveis pela hidrólise e acidogênese de substratos lignocelulósicos. Em comparação com as outras fontes de inóculo, tem-se para 
a população microbiana do rúmen maior atividade hidrolítica e acidogênica da biomassa lignocelulósica, uma vez que há elevado sinergismo entre os micro-organismos. Como produtos intermediários principais, os ácidos voláteis podem ser usados para produzir outros compostos de energia, incluindo eletricidade em células a combustível microbianas, hidrogênio, metano, bioplásticos e outros (YUE et al., 2013).

Entre as populações celulolíticas do rúmen, os ruminococos são os principais responsáveis pela produção de hidrogênio, ao passo que Fibrobacter succinogenes, apenas está relacionada com eficiente degradação de celulose, entretanto não produz hidrogênio (FLINT et al., 2008). Representantes desta espécie fermentam glicose, celobiose e celulose em ácido acético, ácido succínico e, em menor proporção, ácido fórmico. Ruminococcus flavifaciens fermenta celulose e celobiose em hidrogênio, gás carbônico, ácido acético, ácido fórmico e etanol, além de outros ácidos orgânicos como láctico e succínico. Ruminococcus albus fermenta celulose e celobiose em, principalmente, hidrogênio, gás carbônico, etanol e ácido acético. Por isso, Ruminococcus albus é a espécie celulolítica mais usada em estudos de produção de hidrogênio a partir de celulose em temperatura mesofílica (NTAIKOU et al., 2008; NTAIKOU; KOUTROS, KORNAROS, 2009).

O fluido de rúmen também contém espécies conhecidamente produtoras de hidrogênio como bacilos formadores de endósporos do gênero Clostridium que podem se estabelecer na cultura por meio da fermentação do papel hidrolisado pelas bactérias celulolíticas. Clostridium acetobutylicum foi identificada em amostra de fluido de rúmen tratada com choque ácido em estudo de produção de hidrogênio a partir de papel hidrolisado (BOTTA, 2012). Neste estudo, foram obtidos elevados rendimentos de hidrogênio, de até $42 \mathrm{mmol} \mathrm{H} / \mathrm{g}$ papel adicionado. Ho et al. (2011) também descreveram bactérias do gênero Clostridium em consórcio microbiano purificado de fluido de rúmen para produzir hidrogênio a partir de capim.

Estudos recentes têm considerado o uso de fluido de rúmen como inóculo para degradação anaeróbia de compostos celulósicos com diversas finalidades biotecnológicas. Hu e Yu (2005) avaliaram a produção de hidrogênio e gás carbônico, com percentual máximo de $21 \%$ de $\mathrm{H}_{2}$ no biogás, além de elevados rendimentos de ácidos orgânicos voláteis $(0,59 \mathrm{~g} / \mathrm{g} \mathrm{SV})$ em reator semicontínuo alimentado com palha de milho. Fluido de rúmen também foi aplicado como inóculo para a produção de ácidos orgânicos voláteis a partir de taboa, e foram obtidos principalmente ácido acético, propiônico e butírico, além de baixas concentrações de i-butirato, i-valerato e valerato (HU; YU, 
ZHENG, 2006). Estes autores afirmaram que a acidogênese usando culturas ruminais é um método promissor para a disposição de biomassa vegetal.

Para produção de metano, resíduo de papel foi usado como modelo de biomassa celulósica após pré-tratamento com fluido de rúmen. O substrato foi previamente incubado com fluido de rúmen, para posterior incubação visando a geração de metano. Após o pré-tratamento, foi obtido principalmente ácido acético, e a produção de metano foi 2,6 vezes maior com papel sem tratamento, o que resultou em 73,4\% do rendimento teórico de metano. A degradação de celulose e outros polissacarídeos foi otimizada após pré-tratamento com fluido de rúmen (BABA et al., 2013).

Visto que o rúmen hospeda espécies importantes relacionadas à degradação de celulose, bem como espécies fermentativas acidogênicas, tem-se para o fluido de rúmen uma fonte interessante de inóculo para sistemas únicos de degradação de material celulósico com recuperação de energia na forma de hidrogênio e outros compostos orgânicos de interesse biotecnológico como ácidos orgânicos e solventes.

\subsection{Processos biológicos consumidores de hidrogênio}

Consórcios anaeróbios obtidos de fontes naturais contêm micro-organismos consumidores de $\mathrm{H}_{2}$. São eles as arqueias metanogênicas, bactérias redutoras de sulfato, nitrato e ferro e bactérias produtoras de ácidos propiônico, láctico, butírico, valérico e capróico e álcoois. Todos estes micro-organismos usam o hidrogênio como doadores de elétrons (ANGENENT et al., 2004; CARVER et al., 2011; SAADY, 2013).

O impasse em relação ao uso de consórcios naturais mistos para otimizar a degradação de celulose em sistemas biotecnológicos de produção de hidrogênio refere-se ao consumo de hidrogênio. Em ecossistemas anaeróbios, os metanogênicos, acetogênicos e redutores de sulfato competem por hidrogênio produzido pelas espécies hidrolíticas. Esses metabolismos consumidores deste gás também ocorrem no rúmen (DURAND et al., 2010). A remoção eficiente de hidrogênio leva ao aumento da eficiência de crescimento das bactérias celulolíticas produtoras de hidrogênio. Portanto, há sempre tendência natural de consumo deste gás em consórcios anaeróbios (FLINT et al., 2008). (Figura 3.2) 


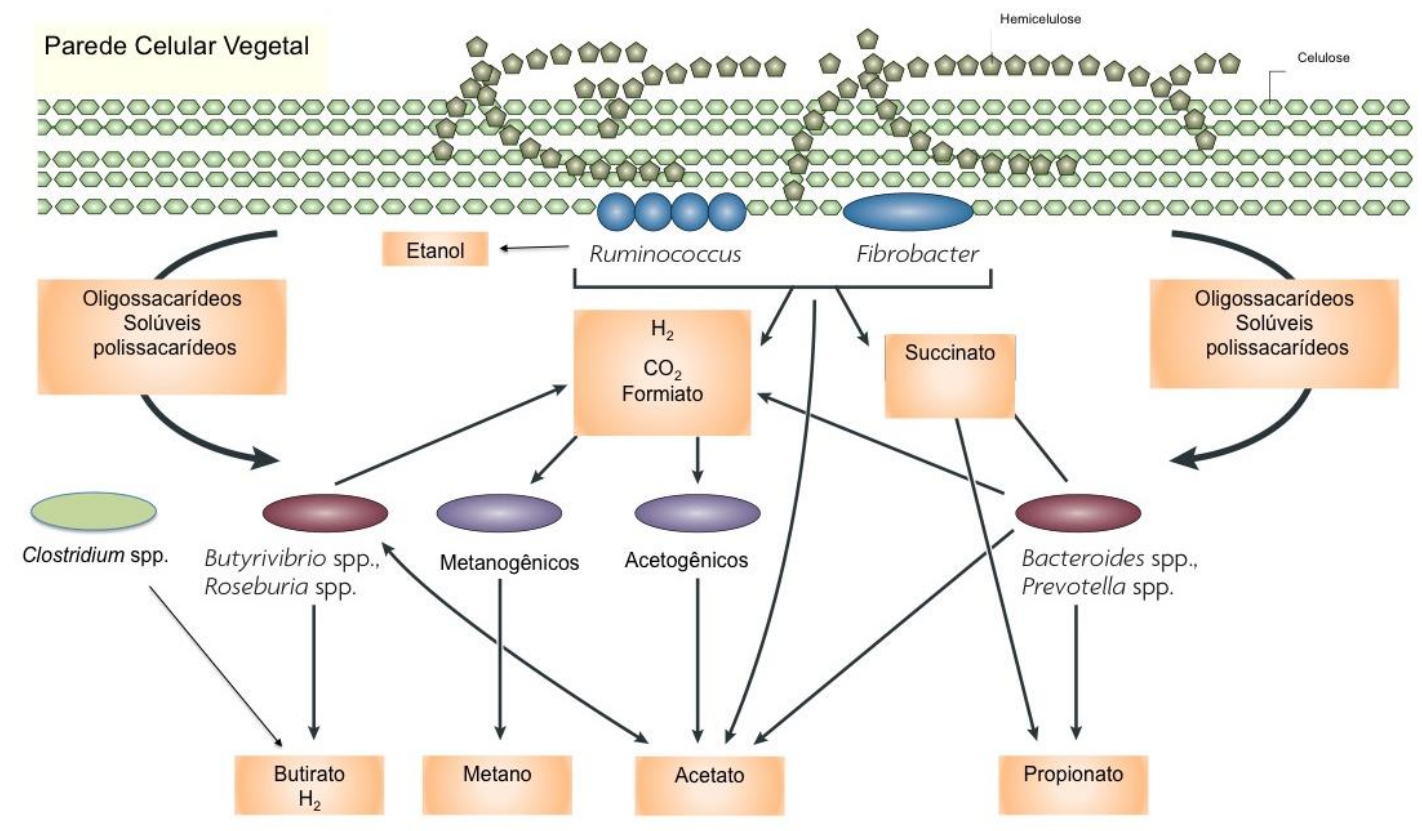

Figura 3.3 - Metabolismos desenvolvidos pela microbiota do rúmen

Fonte: Modificado de Flint et al. (2008).

Em relação às bactérias do rúmen, as espécies celulolíticas especialistas, Ruminococcus e Fibrobacter são as degradadoras primárias de celulolse, e então se aderem firmemente ao substrato. Estão presentes outras bactérias capazes de utilizar polímeros solúveis, como as semelhantes a Clostridium, as produtoras de ácido butírico Butyvibrio spp. e Roseburia spp., as produtoras de ácido succínico Bacteroides spp. e Prevotella spp., além das consumidoras de hidrogênio, metanogênicas, acetogênicas e redutoras de sulfato (FLINT et al., 2008).

De acordo com Saady (2013), o hidrogênio pode ser consumido de duas formas: (1) como equivalentes redutores $\left(\mathrm{NADH}_{2} ; \mathrm{H}_{2}\right.$ potencial) - o consumo de $\mathrm{NADH}_{2}$ previne a formação de $\mathrm{Fd}_{\text {red }}$ (Ferredoxina reduzida) e formiato que levam à geração de $\mathrm{H}_{2}$. Nas reações de produção de ácidos orgânicos voláteis como lático, propiônico, butírico, valérico, capróico, além de álcoois, tem-se o $\mathrm{NADH}_{2}$ como doador de elétrons; (2) como hidrogênio molecular $\left(\mathrm{H}_{2}\right)$ para a geração de ácido acético e $\mathrm{CH}_{4}$ produzidos por homoacetogênicos e metanogênicos hidrogenotróficos, respectivamente.

Para aumentar o rendimento de $\mathrm{H}_{2}$ deve-se eliminar ou inibir os micro-organismos que realizam esses metabolismos (HAWKES et al., 2007). Geralmente, na fermentaçãorespiração anaeróbia e anóxica, os receptores de elétrons (sulfato, nitrato e ferro) devem ser desfavorecidos, uma vez que usam hidrogênio como doador de elétrons (CARVER et al., 2012). Entretanto, o dióxido de carbono no headspace não pode ser eliminado, de 
forma que os homoacetogênicos e metanogênicos reduzem-no com $\mathrm{H}_{2}$ (doador) em ácido acético e metano, respectivamente. Baseado no modelo trófico teórico da digestão anaeróbia sugerido por McInerney e Bryant (1981), a inibição da metanogênese ativa a homoacetogênese ou solventogênese.

A inibição afeta alguns grupos do consórcio anaeróbio e causa um desequilíbrio cinético entre os acidogênicos, acetogênicos e metanogênicos, pois há uma alteração do fluxo de elétrons entre esses micro-organismos. Acidogênicos geralmente respondem ao acúmulo de ácidos orgânicos voláteis, alterando o metabolismo de produção de ácido acético em subprodutos mais reduzidos, como ácido propiônico, ácido butírico ou ácido láctico, ou para a solventogênese. O acúmulo de compostos reduzidos já foi associado à baixos rendimentos de $\mathrm{H}_{2}$ (LEE et al., 2008).

A homoacetogênese é realizada por micro-organismos acetogênicos que alteram o metabolismo heterotrófico para metabolismo autotrófico com consumo de $\mathrm{H}_{2} / \mathrm{CO}_{2}$, sob condições de estresse ou depleção de substrato orgânico reduzido (eq.1). Além disso, as bactérias homoacetogênicas têm a habilidade de tolerar ampla gama de condições ambientais (PARKIN, OWEN, 1986) como por exemplo, elevada pressão parcial de $\mathrm{H}_{2}$. De acordo com Demirel e Scherer, (2008), quando a pressão parcial de $\mathrm{H}_{2}$ é > $500 \mathrm{~Pa}$, a homoacetogênese é favorecida. E, sob condições de pHs reduzidos, a homoacetogênese prevalece a metanogênese hidrogenotrófica (WEJIMA et al., 2002). Essas características dão às bactérias homoacetogênicas vantagens sobre outros micro-organismos sob condição de estresse ambiental (SAADY, 2013).

$$
4 \mathrm{H}_{2}+2 \mathrm{CO}_{2} \rightarrow \mathrm{CH}_{3} \mathrm{COOH}+2 \mathrm{H}_{2} \mathrm{O}
$$

Embora a inibição da metanogênese por meio de pré-tratamentos tenha sido comprovada em muitos estudos que realizaram cultivos em batelada, pouco se sabe sobre a homoacetogênese, que tem aparecido como um importante metabolismo que envolve consumo de $\mathrm{H}_{2}$ em reatores anaeróbios. Sob condição mesofílica (30-37 $\left.{ }^{\circ} \mathrm{C}\right)$, Akutsu et al. (2008) não conseguiram estabilizar a produção de hidrogênio a partir de amido em reatores contínuos, e o gás produzido continha principalmente $\mathrm{CO}_{2}$. Os autores mencionaram que o hidrogênio foi consumido via homoacetogênese em experimentos em batelada.

Exceção à formação de ácido acético a partir de piruvato, tem-se para a maioria das reações acidogênicas consumo de $\mathrm{H}_{2}$ exclusivo ou parcial (SAADY, 2013). As 
reações de formação dos ácidos valérico e capróico a partir de propiônico e butírico, respectivamente, consomem 6 mols de $\mathrm{H}_{2}$ cada, em condições de $\mathrm{pH}<4$. Outros metabolismos que envolvem o consumo de hidrogênio são a produção dos ácidos propiônico, valérico e capróico como ilustrado nas equações 2, 3 e 4. Espécies produtoras de ácido propiônico foram reportadas como dominantes em condição de estresse ambiental, com elevada carga orgânica aplicada.

Ác. propiônico: $\mathrm{C}_{6} \mathrm{H}_{12} \mathrm{O}_{6}+2 \mathrm{H}_{2} \rightarrow 2 \mathrm{CH}_{3} \mathrm{CH}_{2} \mathrm{COOH}+2 \mathrm{H}_{2} \mathrm{O}$

Ác. valérico: $\mathrm{CH}_{3} \mathrm{CH}_{2} \mathrm{COO}^{-}+2 \mathrm{CO}_{2}+6 \mathrm{H}_{2} \rightarrow \mathrm{CH}_{3}\left(\mathrm{CH}_{2}\right) 3 \mathrm{COO}^{-}+4 \mathrm{H}_{2} \mathrm{O}$

Ác. Capróico: $\mathrm{CH}_{3}\left(\mathrm{CH}_{2}\right)_{2} \mathrm{COO}^{-}+2 \mathrm{CO}_{2}+6 \mathrm{H}_{2} \rightarrow \mathrm{CH}_{3}\left(\mathrm{CH}_{2}\right)_{4} \mathrm{COO}^{-}+4 \mathrm{H}_{2} \mathrm{O}$ (eq.4)

Além disso, o hidrogênio também pode ser consumido durante a conversão de etanol a ácido acético, que é termodinamicamente favorável em condições de elevada pressão parcial de hidrogênio (DIEKERT; WOHLFARTH, 1994).

O principal gênero produtor de hidrogênio, Clostridium, também pode ser prejudicial ao sistema, por exemplo, a produção de ácido propiônico por Clostridium articum é um metabolismo de consumo de hidrogênio. Similarmente, à geração de etanol e ácido láctico por Clostridium barkeri resulta em ausência de hidrogênio (KHANAL et al., 2003).

O uso de culturas mistas como inóculo em sistemas para produção de vetores energéticos a partir de matérias-primas residuais apresenta essa desvantagem do menor rendimento de $\mathrm{H}_{2}$ em função do desvio metabólico para produção de compostos como ácidos orgânicos e etanol, por exemplo. Entretanto, o uso de culturas puras para a aplicação em escala plena também tornaria o processo inviável. Dessa forma, o mais interessante a se fazer é recuperar todos os compostos gasosos e líquidos de interesse biotecnológico resultantes da fermentação de resíduos a fim de que esse processo se torne tecnologicamente e economicamente favorável. 


\section{5 Ácidos Orgânicos Voláteis - subprodutos de interesse biotecnológico}

Os ácidos orgânicos voláteis (AOVs) também têm sido foco de pesquisas pelas possibilidades de aplicações na produção de bioplásticos (CAI et al., 2009), bioenergia (CHOI; CHANG; HAN, 2011; UYAR et al., 2009) e remoção biológica de nutrientes a partir de águas residuárias (ZHENG; CHEN, LIU, 2010). A produção comercial de AOVs é majoritariamente realizada por processos químicos, entretanto o uso de petroquímicos não renováveis como matéria-prima e o aumento do preço do petróleo renovaram o interesse nas rotas biológicas de produção desses compostos (LEE et al., 2014). O uso de água residuária e resíduos orgânicos para a produção de AOVs são alternativa sustentável de manejo de resíduos.

Variedade de resíduos líquidos e sólidos tem sido estudada como substrato potencial para a produção de AOV. Dentre os resíduos sólidos, os mais estudados são lodo, resíduos alimentícios e fração orgânica dos resíduos sólidos domésticos. Já entre os líquidos, esgoto doméstico, águas residuárias de atividade agrícola e indústria de papel e celulose são os mais usados para a produção de AOVs (LEE et al., 2014).

Geralmente, é possível utilizar efluentes fermentados ricos em AOVs diretamente nas suas aplicações. Algumas aplicações de AOVs serão discutidas a seguir. Após o controle das concentrações de amônia e fosfato do efluente fermentado, este pode ser utilizado para a conversão microbiana de ácidos orgânicos voláteis a polihidroxialcanoatos (PHA), que são polímeros biodegradáveis sintetizados por microorganismos, com aplicação em diferentes ramos industriais (PHILIP; KESHAVARZ, ROY, 2007). Ademais, os AOVs podem ser utilizados na geração de diferentes formas de energia, como por exemplo, a geração direta de eletricidade pelas células a combustível microbianas (KARRA et al., 2013; WANG, REN, 2014), além de serem usados na produção de biogás, hidrogênio e biodiesel (LEE et al., 2014).

A produção de metano a partir de AOVs pode ser realizada, com sucesso, em sistemas bifásicos, em que micro-organismos acidogênicos e metanogênicos são divididos em dois digestores separados. Enquanto, o primeiro digestor contém condições operacionais para a fermentação acidogênica, o segundo contém condições que favorecem a produção de metano a partir de AOVs. Além disso, nesses sistemas é possível a recuperação simultânea de hidrogênio e metano, tornando o sistema ainda mais interessante (HASSAN et al., 1997). 
Além do metano, a obtenção de energia na forma de hidrogênio a partir de AOVs pode se dar por meio de foto-fermentação, eletro-hidrólise ou células a combustível microbianas (LEE et al., 2014).

Dessa forma, pode-se concluir que a produção de efluentes ricos em ácidos orgânicos voláteis a partir de substratos renováveis, especialmente residuais, é interessante do ponto de vista tecnológico devido às inúmeras possibilidades de aplicação desses compostos orgânicos em outros sistemas biotecnológicos de produção de energia ou adequação ambiental.

\subsection{Considerações finais}

A partir da revisão da literatura, foi possível evidenciar que a fermentação anaeróbia de carboidratos para a produção de biocombustíveis vem sendo extensivamente estudada e pode ser considerada viável econômica e operacionalmente. Uma das principais vantagens desse processo fermentativo é a possibilidade de combinar o tratamento de resíduos com as elevadas taxas de produção de energia na forma de hidrogênio em um mesmo sistema industrial já utilizado em escala real para produção de metano.

Os estudos disponíveis na literatura sobre produção de hidrogênio por fermentação de matéria orgânica visaram, principalmente, caracterizar e otimizar substratos, design de reatores, pré-tratamentos da cultura microbiana para enriquecimento de bactérias fermentativas e parâmetros operacionais. Nesses estudos foram descritos experimentos realizados em curtos períodos de operação em escala de laboratório, de forma que uma análise mais criteriosa do consumo de hidrogênio via fermentação mista, que resulta em baixos rendimentos de hidrogênio, ainda é escassa.

A fermentação de matéria orgânica por cultura mista é um processo natural que ocorre para maximizar o crescimento celular e não o rendimento de hidrogênio. Em ambientes naturais, os produtos intermediários da fermentação, como hidrogênio, ácidos orgânicos e álcoois são convertidos a metano. Quando micro-organismos consumidores de hidrogênio são inibidos em uma cultura anaeróbia, a distribuição de produtos intermediários depende das condições ambientais, como $\mathrm{pH}$, pressão parcial de hidrogênio, espécies de micro-organismos e concentração de substrato. 
O papel é um composto celulósico encontrado em altas porcentagens nos resíduos sólidos domésticos. O aumento da população, industrialização e crescimento urbano desornado implicam no aumento da geração de resíduos sólidos e dificuldade de gerenciálos. Para exemplificar, um estudo de caso identificou que a porcentagem média de papel nos resíduos sólidos domésticos foi de 35\%, 25\% e 15\% nos Estados Unidos, União Europeia e países subdesenvolvidos, respectivamente.

A utilização de papel como reserva de carbono e energia permite a redução de resíduos a ser disposto em aterros sanitários, o que pode atenuar problemas de falta de espaço e custo para manejo de resíduos urbanos, como também possibilita agregar valor aos produtos intermediários da degradação deste substrato. O uso de papel, em especial na forma de hidrolisado, tem sido considerado por muitos pesquisadores em experimentos em batelada, porém poucos são os estudos reportados com operação contínua de reatores biológicos.

Dessa forma, idealizou-se a obtenção de hidrogênio e outros produtos intermediários a partir da fermentação acidogênica de papel em lisímetros, usando cultura mista como inóculo. O desenvolvimento e adaptação da cultura purificada do fluido de rúmen e operação dos lisímetros foram realizados em temperatura mesofílica e termofílica, sob diferentes concentrações e teores de umidade do papel (substrato).

Por meio desta pesquisa, foi possível avaliar a influência dos parâmetros de operação ( $\mathrm{pH}$, temperatura, umidade e concentração de substrato) nas rotas metabólicas desempenhadas pelos micro-organismos em cultura purificada do fluido de rúmen. 


\section{MATERIAL E MÉTODOS}

Este estudo consistiu na obtenção de um consórcio microbiano fermentativo e celulolítico a partir do fluido de rúmen bovino a fim de realizar fermentação acidogênica da matéria orgânica celulósica. Esse consórcio fermentativo, não metanogênico, purificado do fluido de rúmen foi aplicado em lisímetros para degradação de papel com recuperação de energia e outros compostos de interesse biotecnológico.

Uma fase preliminar de operação foi realizada para definição das condições de operação de um protótipo de lisímetro, sendo testados a montagem do sistema, inoculação do papel, o uso de spray para umidificação homogênea do leito de papel, frequência e volume de meio adicionado para umidificação, coleta de amostra líquida, e definição do pH inicial. Após as etapas preliminares, os lisímetros foram operados no modelo de Planejamento de Experimentos, sendo um Delineamento Composto Central (Fatorial $2^{3}$ ), com repetição dos pontos centrais (RODRIGUES; IEMMA, 2014), considerando três variáveis diferentes, cada um com três níveis (Figura 4.1). Os fatores avaliados foram temperatura de operação $\left(35,45\right.$ e $\left.55^{\circ} \mathrm{C}\right)$, massa de papel seco $(500,750$ e $1000 \mathrm{~g})$ e teor de umidade do papel $(50,65,80 \%)$. Nesta fase o objetivo foi determinar quais são as melhores condições para a fermentação acidogênica de resíduos sólidos celulósicos, fazendo-se o uso de papel limpo como substrato modelo.

Após a finalização das operações dos lisímetros, três condições foram selecionadas para a caracterização filogenética da biomassa microbiana por sequenciamento massivo do gene RNAr 16S via Plataforma Illumina, a fim de se associar os produtos detectados no biogás e percolado destes lisímetros e as vias metabólicas desempenhadas pelos micro-organismos. Foram identificados os micro-organismos da amostra do fluido de rúmen in natura (origem do inóculo), fluido de rúmen purificado, e da biomassa dosu lisímetros de cada temperatura estudada R2 (500 g; 80\%; 35 $\left.{ }^{\circ} \mathrm{C}\right), \mathrm{R} 5$ $\left(1000 \mathrm{~g} ; 80 \% ; 55^{\circ} \mathrm{C}\right)$ e R9 $\left(750 \mathrm{~g} ; 65 \% ; 45^{\circ} \mathrm{C}\right)$. 


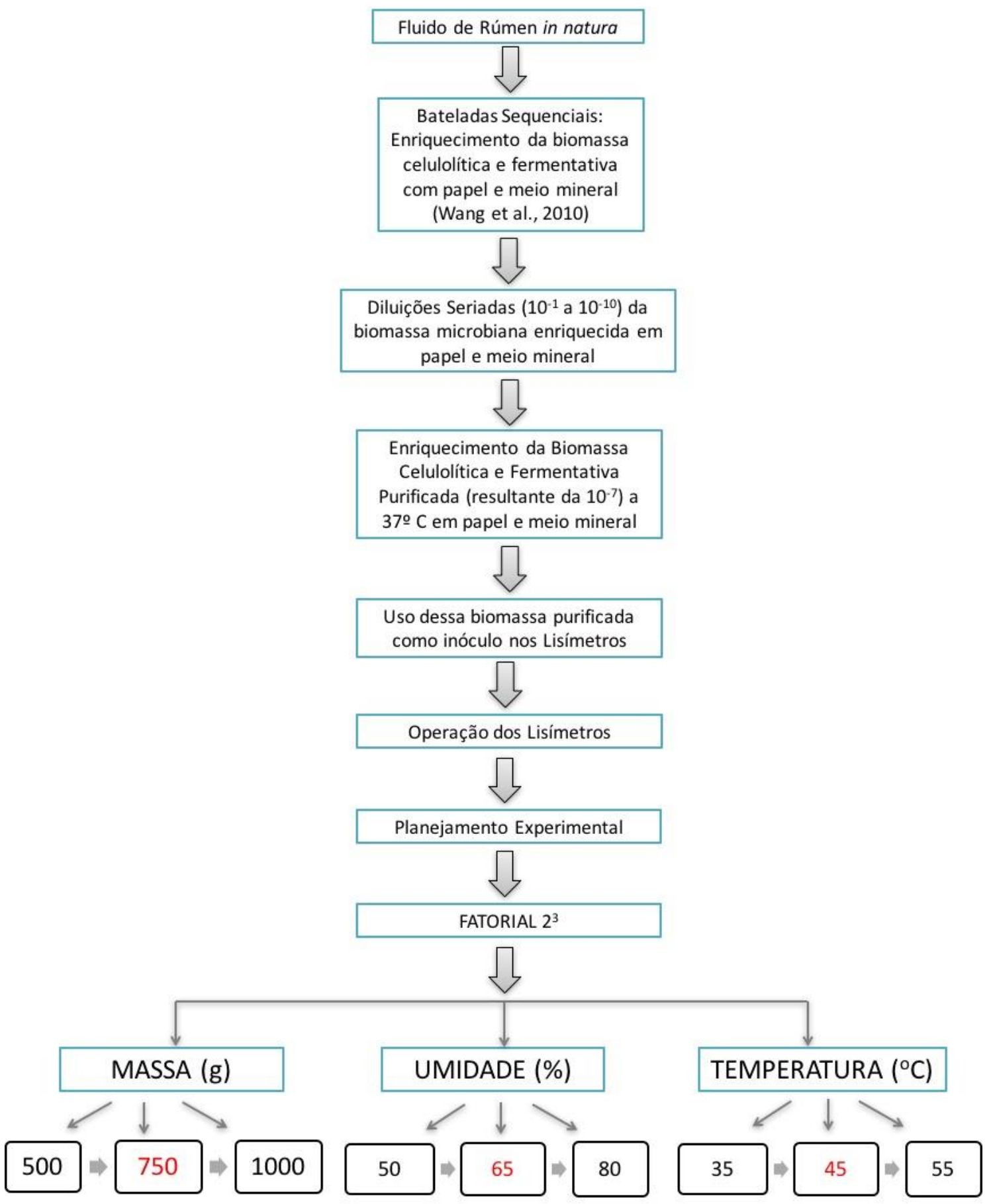

Figura 4.1 - Fluxograma das atividades desempenhadas desde a obtenção do fluido de rúmen in natura até a operação dos lisímetros no modelo Fatorial $2^{3}$

\subsection{Inóculo}

Para a obtenção de bactérias celulolíticas e fermentativas, o inóculo usado foi proveniente do fluido de rúmen bovino, cedido pela Embrapa - Pecuária Sudeste (Fazenda Canchim, São Carlos - SP). O fluido de rúmen foi coletado in natura por meio 
de uma fístula permanente no rúmen do animal (Figura 4.2). O volume coletado foi submetido à filtração em tecido de algodão para retirada do material lignocelulósico grosseiro, e posteriormente, transportado em vasilhame térmico. $\mathrm{O}$ pH do fluido logo após a coleta era 8,1 .

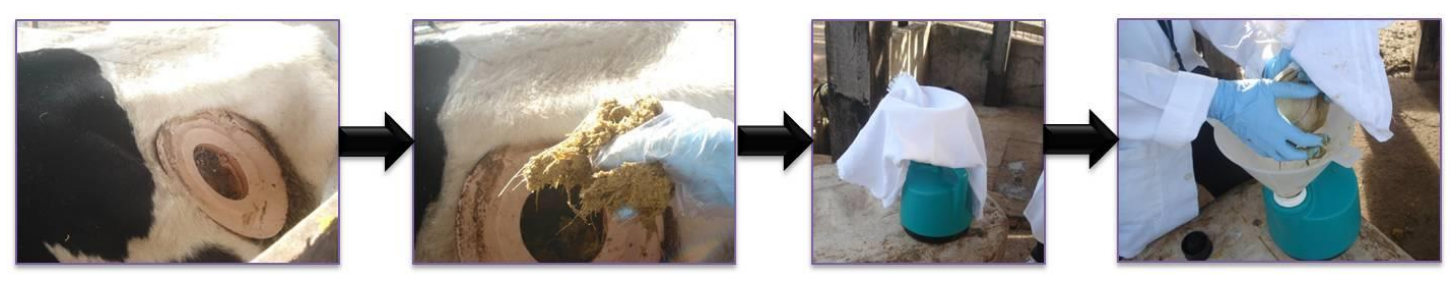

Figura 4.2 - Coleta do fluido de rúmen bovino: (A) fístula permanente na porção do rúmen; (B) retirada do material lignocelulósico embebido no fluido Fonte: Botta (2012). ruminal; $(C)$ vasilhame térmico

No laboratório foi realizado o processamento do fluido para uso e armazenamento. Nos frascos de Duran $(500 \mathrm{~mL})$ contendo solução de solubilização (vide item X.X) previamente esterilizados e mantidos sob condição de anaerobiose, foram acondicionados $100 \mathrm{~mL}$ do fluido ruminal, sob atmosfera de $\mathrm{N}_{2} / \mathrm{CO}_{2}$ (70/30\%). Os frascos foram fechados com tampa de butila e rosca plástica e submetidos a agitação manual por 30 minutos em temperatura ambiente, a fim de proporcionar a homogeneização da amostra. Os frascos contendo inóculo foram estocados sob refrigeração a $4{ }^{\circ} \mathrm{C}$ (GIAJ-LEVRA, 1991). Esse material foi utilizado como inóculo para os ensaios de enriquecimento. Outra parte do fluido de rúmen in natura coletado foi armazenada na forma bruta, com adição apenas de $1 \mathrm{~mL}$ de solução redutora de sulfeto de sódio (5\%) e $1 \mathrm{~mL}$ de tampão fofasto (vide item X.X). Este material foi utilizado como inóculo para os ensaios de enriquecimento.

4.1.1 Obtenção de Consórcio Microbiano Celulolítico e Fermentativo a Partir do Fluido de Rúmen

Para a obtenção de um consórcio essencialmente celulolítico e fermentativo, foram testados três meios de cultura diferentes, a fim de se analisar em qual dos meios a produção de hidrogênio era favorecida em relação à produção de metano. Os três meios de cultura eleitos para serem testados tratam-se de meios descritos para o cultivo de bactérias celulolíticas e/ou produtoras de hidrogênio em ambientes anaeróbios. Os meios 
utilizados foram os seguintes: Meio descrito por Ho et al. (2011) (Meio A), Meio para cultivo e conservação de Ruminococcus albus: Ruminococcus albus modificado (ATLAS, 2005) (Meio B) e Meio para cultivo de bactéria celulolítica anaeróbia "Cellulose Anaerobe Medium” ou CAM modificado (ATLAS, 2005) (Meio C). O preparo das soluções e destes meios de culturas está descritos no item 4.2.

A obtenção do inóculo foi realizada em frascos de antibiótico com volume total de $100 \mathrm{~mL}$ do qual $55 \mathrm{~mL}$ corresponderam ao volume reacional $(50 \mathrm{~mL}$ meio de cultura + $5 \mathrm{~mL}$ líquido ruminal) e $45 \mathrm{~mL}$ ao headspace $\left(\mathrm{N}_{2} / \mathrm{CO}_{2}-70 \% / 30 \%\right)$. Os reatores foram alimentados com papel sulfite $(2,86 \mathrm{~g} / \mathrm{L})$, o que correspondeu a 2,0 g/L de celulose. $\mathrm{O}$ fluido de rúmen diluído na solução de solubilização (10\% v/v) foi utilizado como inóculo.

4.1.2 Enriquecimento das Populações Celulolíticas e Fermentativas do Fluido de Rúmen Bovino

Ciclos sequenciais de fermentação em frascos de vidro em meio CAM foram realizados a fim de aumentar a população celulolítica e fermentativa do consórcio microbiano, suprimindo o crescimento de arqueias metanogênicas. Para tanto, controlava-se a evolução de hidrogênio no headspace e, uma vez produzido esse gás, os frascos eram armazenados na geladeira, a fim de retardar o aumento das populações metanogênicas do consórcio.

Posteriormente, a partir desses reatores mencionados anteriormente procedeu-se a diluições seriadas com o objetivo de eliminar completamente a população metanogênica restante no consórcio microbiano. Diluições de $10^{-1}$ a $10^{-10}$ foram preparadas em triplicata, em frascos Duran de $250 \mathrm{~mL}$, contendo $100 \mathrm{~mL}$ de volume reacional e $150 \mathrm{~mL}$ de headspace. Os frascos foram fechados com tampa de butila e rosca plástica, e incubados a $37^{\circ} \mathrm{C}$. Foi utilizado o meio de cultivo CAM como fonte exclusivamente de mineirais, e 2,0 g/L de papel sulfite como fonte única de carbono. Para manutenção de condições anaeróbias, foi fluxionado $\mathrm{N}_{2} / \mathrm{CO}_{2}(70 \% / 30 \%)$ no headspace. Análises periódicas (4 em 4 dias) de $\mathrm{H}_{2}$ foram realizadas ao longo de um período de aproximadamente 50 dias. 


\subsubsection{Enriquecimento e Manutenção do Inóculo Purificado}

O enriquecimento e manutenção do inóculo foram realizados em frascos de Duran com volume total de 2L. Para enriquecimento e manutenção da biomassa obtida, preparou-se $1 \mathrm{~L}$ de meio nutricional CAM reformulado (com sais de cloreto). Adicionouse $10 \%$ do volume total de inóculo e papel sulfite como substrato $(2 \mathrm{~g} / \mathrm{L})$. Após a inoculação, os reatores foram submetidos à atmosfera de $\mathrm{N}_{2}$ (100\%), durante 20 minutos, para a troca gasosa no volume reacional e de headspace, de forma a manter o ambiente anaeróbio. Após a distribuição do meio de cultivo e inóculo, e da troca gasosa no headspace, os reatores foram fechados com tampa de butila e rosca plástica, e incubados a $37^{\circ} \mathrm{C}$. A cada 7 dias, nova série de reatores foi montada, usando como inóculo o volume líquido dos frascos de cultivo anteriormente preparados, de forma a enriquecer e aumentar a biomassa. O enriquecimento celular foi monitorado com análises esporádicas de produção de $\mathrm{H}_{2}$.

\subsection{Preparação de Soluções e Meios de Cultura}

\subsubsection{Solução de Solubilização}

Em frascos de Duran ${ }^{\circledR}$ de $500 \mathrm{~mL}$, foram adicionadas $20 \mathrm{~g}$ de pérolas de vidro, $245 \mathrm{~mL}$ de água ultra purificada, 2,5 mL de solução de bicarbonato de sódio a 10\%, 2,5 $\mathrm{mL}$ de solução de $\mathrm{Na}_{2} \mathrm{~S} . \mathrm{H}_{2} \mathrm{O}$ a $5 \%$ e $0,25 \mathrm{~mL}$ de solução de resazurina a $0,1 \%$ (Tabela 4.3). Após o preparo desta solução de solubilização do fluido de rúmen in natura, foi realizada a troca da atmosfera aeróbia para anaeróbia, por meio da injeção de mistura de $\mathrm{N}_{2} / \mathrm{CO}_{2}(70 \% / 30 \%)$, até que a solução ficasse totalmente transparente, indicando sua anaerobiose. Após a finalização do preparo, os frascos foram submetidos à esterilização em auto-clave, a $120^{\circ} \mathrm{C}$ e 1 atm, durante 20 minutos. 
Tabela 4.1 - Composição da Solução de Solubilização

\begin{tabular}{cc}
\hline Composição & Volume (mL) \\
\hline Resazurina 0,1\% & 0,25 \\
$\mathrm{NaHCO}_{3} 10 \%$ & 2,50 \\
$\mathrm{Na}_{2} \mathrm{~S} .9 \mathrm{H}_{2} \mathrm{O} 5 \%$ & 2,50 \\
Água Ultra purificada & 245 \\
Atmosfera Gasosa & $\mathrm{N}_{2} / \mathrm{CO}_{2}(70 / 30 \%)$
\end{tabular}

Fonte: Giaj-Levra (1991).

\subsubsection{Solução de Resazurina}

Para o preparo da solução de resazurina, adicionou-se $0,1 \mathrm{~g}$ de resazurina em 100 $\mathrm{mL}$ de água ultra-purificada em um frasco de Duran ${ }^{\circledR}$. A solução foi mantida refrigerada a $4^{\circ} \mathrm{C}$

\subsubsection{Solução Redutora de Sulfeto de Sódio}

Para o preparo da solução redutora de sulfeto de sódio, dissolveu-se $5 \mathrm{~g} \mathrm{de} \mathrm{Na}_{2} \mathrm{~S}$ em 100 mL de água ultra-purificada. A água utilizada para fazer a solução foi previamente aquecida até atingir fervura, permanecendo neste estado por 5 minutos, e então fluxionouse $\mathrm{N}_{2}(100 \%)$ para torná-la água anaeróbia. A esterilização desta solução se deu por meio de filtração em sistema Millipore com membrana de poro $0,22 \mu \mathrm{m}$, previamente esterilizado em auto-clave, a $121{ }^{\circ} \mathrm{C}$ e $1 \mathrm{~atm}$, por 20 minutos. $\mathrm{O}$ frasco foi fechado com tampa de butila e armazenado sob refrigeração a $4^{\circ} \mathrm{C}$. A cada uso, coletava-se uma alíquota da solução sob condições de assepsia.

\subsubsection{Tampão Fostato Salino (PBS) - 10x}

Para o preparo da solução tampão fosfato salino (PBS) 10X, dissolvia-se os sais e reagentes na ordem apresentada na Tabela 4.2, em $800 \mathrm{~mL}$ de água ultrapurificada. Em seguida, o pH da solução era ajustado para 7,4, fazendo-se o uso de solução de $\mathrm{NaOH} 1 \mathrm{M}$ ou $\mathrm{HCl} 1 \mathrm{M}$. Após o ajuste de pH, acertava-se o volume em $1000 \mathrm{~mL}$. O tampão era esterilizado em autoclave, a $120^{\circ} \mathrm{C}$ e 1 atm, por 20 minutos, e posteriormente foi armazenado à temperatura ambiente. 
Tabela 4.2 - Sais e Reagentes que compõem o Tampão PBS 10X

\begin{tabular}{cc}
\hline Sais e Reagentes & $\begin{array}{c}\text { Quantidades }- \text { q.s.p. 1000 mL de água } \\
\text { ultra-purificada }\end{array}$ \\
\hline Cloreto de Sódio $(\mathrm{NaCl})$ & $80 \mathrm{~g}$ \\
Cloreto de Potássio $(\mathrm{KCl})$ & $2 \mathrm{~g}$ \\
Fosfato de Sódio Dibásico $\left(\mathrm{Na}_{2} \mathrm{HPO}_{4}\right)$ & $14,4 \mathrm{~g}$ \\
Fosfato de Potássio Monobásico $\left(\mathrm{KH}_{2} \mathrm{PO}_{4}\right)$ & $2,4 \mathrm{~g}$ \\
\hline
\end{tabular}

Fonte: Sambrook et al. (1989).

\subsubsection{Solução Mista de Ácidos Graxos}

Para a preparação da solução mista de ácidos graxos, usada no meio B, foram adicionados $10 \mathrm{~mL}$ de ácido isobutírico e $10 \mathrm{~mL}$ de ácido isovalérico em $100 \mathrm{~mL}$ de água ultrapurificada. A água utilizada para fazer a solução foi previamente aquecida até atingir fervura, permanecendo neste estado por 5 minutos, e então fluxionou-se $\mathrm{N}_{2}(100 \%)$ para torná-la água anaeróbia. A solução foi preparada em um frasco de Duran $\AA_{\text {, e foi }}$ esterilizada em autoclave a $121^{\circ} \mathrm{C}$ e $1 \mathrm{~atm}$, por 20 minutos. Após a esterilização, a solução foi armazenada sob refrigeração a $4^{\circ} \mathrm{C}$.

\subsubsection{Solução de Cisteína-HCl}

Para o preparo da solução de Cisteína-HCl, foram adicionados $5 \mathrm{~g}$ deste composto (Cisteína-HCl. $\mathrm{H}_{2} \mathrm{O}$ ) em $100 \mathrm{~mL}$ de água. A água utilizada para fazer a solução foi previamente aquecida até atingir fervura, permanecendo neste estado por 5 minutos, e então fluxionou-se $\mathrm{N}_{2}(100 \%)$ para torna-la água anaeróbia. A solução foi preparada em frasco de antibiótico, cuja atmosfera foi mantida em anaerobiose por meio de injeção de $\mathrm{N}_{2}$ por 5 minutos, e esterilizada em auto-clave a $121^{\circ} \mathrm{C}$ e $1 \mathrm{~atm}$, durante 20 minutos. $\mathrm{O}$ frasco, envolto por papel alumínio, foi armazenado sob refrigeração a $4^{\circ} \mathrm{C}$.

\subsubsection{Preparo da Solução de Vitaminas}

A solução de vitaminas era preparada por meio da solubilização de cada componente (Tabela 4.3) em água ultrapurificada, e então, completava-se o volume para $1000 \mathrm{~mL}$ em um frasco de Duran ${ }^{\circledR}$. A água utilizada para fazer a solução era previamente 
aquecida até atingir fervura, permanecendo neste estado por 5 minutos, e então fluxionava-se $\mathrm{N}_{2}(100 \%)$ para torna-la água anaeróbia. A esterilização desta solução se dava por meio de filtração em sistema Millipore com membrana de póro 0,22 $\mu \mathrm{m}$, previamente esterilizado em auto-clave, a $121^{\circ} \mathrm{C}$ e $1 \mathrm{~atm}$, por 20 minutos. $\mathrm{O}$ frasco era fechado com tampa de butila e armazenado sob refrigeração a $4^{\circ} \mathrm{C}$. A cada uso, coletavase uma alíquota da solução sob condições de assepsia.

Tabela 4.3 - Composição da Solução de Vitaminas do Meio C

\begin{tabular}{cc}
\hline Composição $(\mathbf{m g} / \mathbf{L})$ & Meio C \\
\hline piridoxina-HCl & 10 \\
DL- pantotenato de cálcio & 5 \\
Ácido lipoico & 5 \\
Ácido nicotínico & 5 \\
Ácido $p$-aminobenzóico & 5 \\
Riboflavina & 5 \\
Tiamina-HCl & 5 \\
Biotina & 2 \\
Ácido Fólico & 2 \\
Vitamina B12 & 0,1
\end{tabular}

\subsubsection{Meios de Cultura}

Os sais e reagentes que compuseram os meios de cultura utilizados neste trabalho estão descritos na Tabela abaixo.

Tabela 4.4 - Composição dos Meios de cultura testados para enriquecimento das populações celulolíticas e fermentativas do fluido de rúmen

\begin{tabular}{cccc}
\hline & Meio A & Meio B & Meio C \\
Composição (q.s.p. 1000 mL) & Atlas, & Atlas, \\
& $(\mathbf{2 0 1 1})$ & $(\mathbf{2 0 0 5})$ & $(\mathbf{2 0 0 5 )}$ \\
\hline$(\mathrm{NH} 4)_{2} \mathrm{SO}_{4}$ & 1.300 & 800 & 150 \\
$\mathrm{~K}_{2} \mathrm{HPO}_{4}$ & 2.040 & 240 & 296 \\
$\mathrm{KH}_{2} \mathrm{PO}_{4}$ & 40 & 240 & 180 \\
& & & continua
\end{tabular}


continuação

\begin{tabular}{|c|c|c|c|}
\hline Composição (q.s.p. 1000 mL) & $\begin{array}{c}\text { Meio A } \\
\text { Ho et al., } \\
\text { (2011) }\end{array}$ & $\begin{array}{l}\text { Meio B } \\
\text { Atlas, } \\
\text { (2005) }\end{array}$ & $\begin{array}{l}\text { Meio C } \\
\text { Atlas, } \\
\text { (2005) }\end{array}$ \\
\hline $\mathrm{NaHCO}_{3}$ & 400 & 4.000 & 2.100 \\
\hline $\mathrm{NaCl}$ & 80 & 800 & 10 \\
\hline $\mathrm{Mg}_{2} \mathrm{SO}_{4} \cdot 7 \mathrm{H}_{2} \mathrm{O}$ & 19,2 & 100 & 120 \\
\hline $\mathrm{FESO}_{4} .7 \mathrm{H}_{2} \mathrm{O}$ & 1,1 & - & 21 \\
\hline $\mathrm{MnSO}_{4} \cdot \mathrm{H}_{2} \mathrm{O}$ & - & - & 0,1 \\
\hline $\mathrm{CaCl}_{2}$ & 8 & 64 & 61 \\
\hline $\mathrm{NH}_{4} \mathrm{Cl}$ & - & - & 680 \\
\hline $\mathrm{CoCl}_{2} \cdot 6 \mathrm{H}_{2} \mathrm{O}$ & - & - & 0,1 \\
\hline $\mathrm{ZnSO}_{4} \cdot 7 \mathrm{H}_{2} \mathrm{O}$ & - & - & 0,1 \\
\hline $\mathrm{CuSO}_{4} .5 \mathrm{H}_{2} \mathrm{O}$ & - & - & 0,1 \\
\hline $\mathrm{H}_{3} \mathrm{BO}_{3}$ & - & - & 0,1 \\
\hline $\mathrm{Na}_{2} \mathrm{MoO}_{4} \cdot 2 \mathrm{H}_{2} \mathrm{O}$ & - & - & 0,1 \\
\hline $\mathrm{KAl}\left(\mathrm{SO}_{4}\right)_{2} \cdot 12 \mathrm{H}_{2} \mathrm{O}$ & - & - & 0,1 \\
\hline Ácido nitriloacético & - & - & 15 \\
\hline L-cisteína-HCl & - & 500 & $5 \mathrm{~mL}$ \\
\hline $\begin{array}{c}\text { Solução mista de ácidos graxos: ácido } \\
\text { isobutírico (100 mL/L) e ácido isovalérico } \\
(100 \mathrm{~mL} / \mathrm{L})\end{array}$ & - & $1 \mathrm{~mL}$ & - \\
\hline Solução de Vitaminas & - & - & $10 \mathrm{~mL}$ \\
\hline
\end{tabular}

4.2.8.1 Meio A - Meio de Ho et al. (2011)

Para o preparo do meio de cultura descrito por Ho et al. (2011), solubilizava-se cada reagente em uma parcela do volume total de água, e uma vez solubilizados, misturava-os e completava o volume para $1000 \mathrm{~mL}$. A água utilizada para fazer o meio era previamente aquecida até atingir fervura, permanecendo neste estado por 5 minutos, e então fluxionava-se $\mathrm{N}_{2}(100 \%)$ para torná-la água anaeróbia. O pH do meio era ajustado 
para 7,0, fazendo-se o uso de solução de $\mathrm{NaOH} 1 \mathrm{M}$ e $\mathrm{HCl} 1 \mathrm{M}$. O meio era esterizado em auto-clave a $121^{\circ} \mathrm{C}$ e 1 atm por 20 minutos.

\subsubsection{Meio B - Meio de cultivo de Ruminococcus albus}

Para o preparo do meio de cultura B (para cultivo e manutenção de Ruminococcus albus) (Atlas, 2005), solubilizava-se cada reagente em uma parcela do volume total de água, e uma vez solubilizados, misturava-os, adicionava-se $1 \mathrm{~mL}$ da solução mista de ácidos graxos, e completava o volume para $1000 \mathrm{~mL}$. A água utilizada para fazer o meio era previamente aquecida até atingir fervura, permanecendo neste estado por 5 minutos, e então fluxionava-se $\mathrm{N}_{2}(100 \%)$ para torná-la água anaeróbia. O pH do meio era ajustado para 7,0, fazendo-se o uso de solução de $\mathrm{NaOH} 1 \mathrm{M}$ e $\mathrm{HCl} 1 \mathrm{M}$. O meio era esterizado em auto-clave a $121^{\circ} \mathrm{C}$ e $1 \mathrm{~atm}$ por 20 minutos.

\subsubsection{Meio C - Meio CAM (Cellulose Anaerobe Medium)}

Para o preparo de meio de cultura CAM (Atlas, 2005), primeiravemente adicionava-se o ácido nitriloacético em $500 \mathrm{~mL}$ de água ultrapurificada, e ajustava-se o pH para 6,5, fazendo-se o uso de solução de $\mathrm{NaOH} 1 \mathrm{M}$ ou $\mathrm{HCl} 1 \mathrm{M}$, a fim de promover a solubilização de alguns metais, em especial o ferro. Posteriormente, adicionava-se todos os outros reagentes que compunham o meio, exceto a solução de vitaminas. Uma vez feito isso, adicionava-se mais $485 \mathrm{~mL}$ de água ultrapurificada e ajustava-se o $\mathrm{pH}$ para 7.1. $\mathrm{O}$ meio era esterizado em autoclave a $121^{\circ} \mathrm{C}$ e $1 \mathrm{~atm}$ por 20 minutos. Após o resfriamento do meio, era adicionada, em condições de assepsia, $10 \mathrm{~mL}$ de solução de vitaminas (Tabela 4.3). A água utilizada para fazer o meio era previamente aquecida até atingir fervura, permanecendo neste estado por 5 minutos, e então fluxionava-se $\mathrm{N}_{2}$ (100\%) para torná-la água anaeróbia.

\subsection{Definição do Meio de Cultivo para Bactérias Celulolíticas Anaeróbias}

A fim de diminuir a produção de sulfeto pelas bactérias redutoras de sulfato (BRS) oriundas do fluido de rúmen, os sais de sulfato foram substituídos por sais de cloreto. A 
composição reformulada do meio de cultivo C está contida na Tabela 4.5 (q.s.p. 1000 $\mathrm{mL})$.

Tabela 4.5 - Composição do Meio C reformulado

\begin{tabular}{cc}
\hline Composição (q.s.p. 1000 mL) & Meio C \\
\hline $\mathrm{K}_{2} \mathrm{HPO}_{4}$ & 296 \\
$\mathrm{KH}_{2} \mathrm{PO}_{4}$ & 180 \\
$\mathrm{NaCl}$ & 10 \\
$\mathrm{MgCl}_{2}$ & 120 \\
$\mathrm{FeCl}_{3}$ & 21 \\
$\mathrm{MnSO}_{4} \cdot \mathrm{H}_{2} \mathrm{O}$ & 0,1 \\
$\mathrm{CaCl}_{2} \cdot 2 \mathrm{H}_{2} \mathrm{O}$ & 61 \\
$\mathrm{NH}_{4} \mathrm{Cl}$ & 680 \\
$\mathrm{CoCl}_{2} \cdot 6 \mathrm{H}_{2} \mathrm{O}$ & 0,1 \\
$\mathrm{ZnCl}_{2}$ & 0,1 \\
$\mathrm{CuSO}_{4} \cdot 5 \mathrm{H}_{2} \mathrm{O}$ & 0,1 \\
$\mathrm{H}_{3} \mathrm{BO}_{3}$ & 0,1 \\
$\mathrm{Na}_{2} \mathrm{MoO}_{4} .2 \mathrm{H}_{2} \mathrm{O}$ & 0,1 \\
$\left.\mathrm{KAl}_{(} \mathrm{SO}_{4}\right) 2.12 \mathrm{H}_{2} \mathrm{O}$ & 0,1 \\
Ácido nitriloacético & 15 \\
Solução de Vitaminas* & $10 \mathrm{~mL}$ \\
\hline
\end{tabular}

*Solução de vitaminas: vide Tabela 4.3.

\subsection{Substrato orgânico}

Utilizou-se como substrato, tanto nas etapas de enriquecimento das populações celulolíticas e fermentativas do fluido de rúmen bovino, quanto nas operações dos lisímetros, papel de escritório limpo Report Multiuso $75 \mathrm{~g} / \mathrm{m}^{2}$ (Suzano) após fragmentação em máquina fragmentadora de papel PROCALC ES9520. Após a fragmentação, o tamanho dos fragmentos era de $10 \mathrm{~mm}$ x $2 \mathrm{~mm}$, aproximadamente. Foram realizadas no início do experimento, com alíquotas do substrato, determinações de sólidos totais, sólidos totais voláteis e sólidos totais fixos e umidade de acordo com o Standard Methods for the Examination of Water and Wastewater (APHA; AWWA; WEF, 2005). As cápsulas, em duplicata com $5 \mathrm{~g}$ de papel, foram colocadas na estufa a $100{ }^{\circ} \mathrm{C}$ por 24 horas para o cálculo do teor da umidade do papel. Posteriormente, as 
cápsulas foram colocadas em forno mufla a $700{ }^{\circ} \mathrm{C}$ por 30 minutos para volatilização da matéria orgânica e determinação do teor de sólidos totais voláteis e sólidos totais fixos. Assim, foi constatado a seguinte composição do papel em sua condição original: $87,2 \%$ de STV (celulose), $10 \%$ de STF e 2,8\% de teor de umidade.

\subsection{Umidade Papel}

Para uma estimativa do grau de absorção de líquidos, adicionou-se água em excesso a uma amostra de papel de peso conhecido, permanecendo a amostra umidificada em repouso por 24 horas. Após este período, permitiu-se o livre escoamento de água, medindo-se o volume percolado e calculando-se o volume de água absorvido.

Para assegurar que a capacidade máxima de absorção havia sido atingida, verificou-se que novas adições de água provocavam saídas equivalentes de volume de água, e que, portanto, os resíduos estavam realmente saturados. Assim, foi calculada a massa de água necessária para saturar uma massa conhecida de amostra de papel. Em seguida, foi realizada análise de Sólidos Totais (APHA; AWWA; WEF, 2005) a fim de obter a porcentagem em peso que se refere ao teor de umidade $100 \%$ da amostra.

Com base na estimativa da porcentagem em peso de líquido para obtenção de teor de umidade $100 \%$, foram calculadas as porcentagens em peso de líquido necessárias para se atingir os teores de umidade de papel de 50\%, 65\% e 80\%, que foram usadas nas etapas de operação dos biorreatores. Após o cálculo teórico da quantidade de água necessária para se atingir os teores de umidade de 50, 65 e 80\%, foram realizados testes práticos para confirmação dos volumes calculados por meio da anáise de Sólidos Totais (APHA; AWWA; WEF, 2005).

\subsection{Lisímetro}

As unidades experimentais constituíram-se de três lisímetros confeccionados em acrílico com as seguintes dimensões: $60 \mathrm{~cm}$ de altura por $20 \mathrm{~cm}$ de diâmetro. Os lisímetros foram providos dos seguintes dispositivos (Figura 4.3):

- Amostrador de gases constituído por registro de 2,5 cm para derivação de mangueira de silicone para tomada de gases por seringas gas-tight. 
- Entrada de líquidos: formada por tubo de aço inoxidável com $10 \mathrm{~cm}$ de comprimento e $0,5 \mathrm{~cm}$ de diâmetro. $\mathrm{Na}$ extremidade superior, externa ao biorreator, foi adaptada uma mangueira ligada à uma bomba de alimentação. Na extremidade inferior foi acoplado um bico aspersor, por meio do qual foi promovido o fluxo de líquido na forma de spray, de forma a umidificar igualmente todo o diâmetro do biorreator.

- Amostrador para amostra sólida constituído de tampa em rosca para coleta de substrato (papel) para análises de monitoramento da fermentação acidogênica. Foram coletadas amostras de papel no período em que ainda não havia formação de percolado (efluente) do lisímetro.

- Saída de líquido constituída por tubo de PVC curvo de diâmetro igual a $1,9 \mathrm{~cm}$ e comprimento de $10 \mathrm{~cm}$, conectado a uma mangueira de silicone em forma de sifão. Uma camada de $10 \mathrm{~cm}$ de pedregulho foi disposta no fundo dos biorreatores.

- Controle térmico - Câmara com medidas de 1,80 x 1,96 x 1,0 cm. A temperatura interna foi aferida de acordo com cada etapa de operação dos biorreatores, com sistema controlado por meio de aquecedor, ventilador e termostato. 

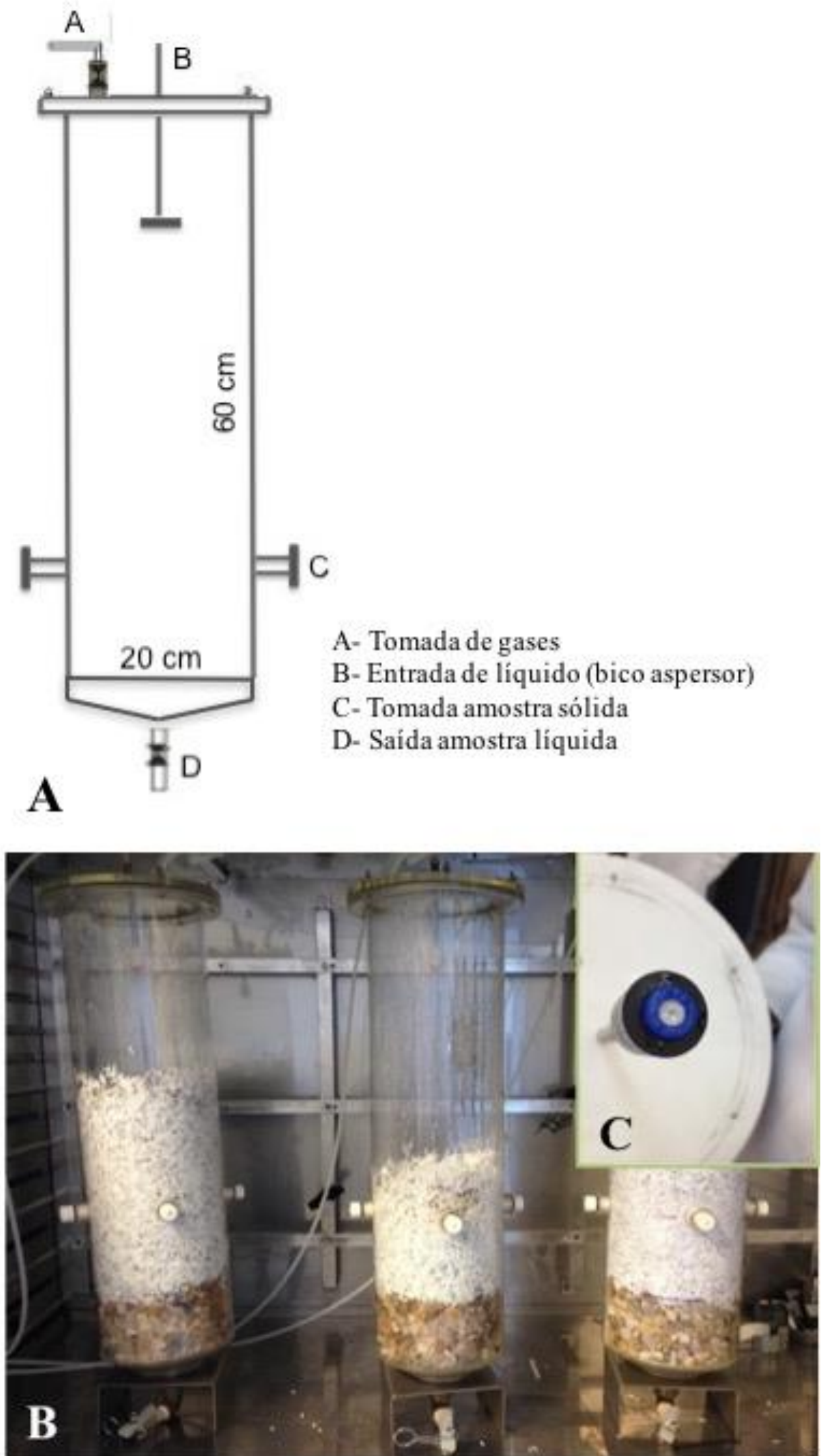

Figura 4.3 - (A) Desenho esquemático do reator (baseado em Baldochi, 1997); (B) Montagem Lisímetros; (C) Detalhe do Bico Aspersor 


\subsubsection{Camada Filtrante}

Em cada unidade de lisímetro, uma camada de pedregulhos de rio $(10 \mathrm{~cm})$ foi disposta no fundo dos lisímetros, como uma camada filtrante do percolado (efluente) formado durante o período de operação. Isso se deveu ao fato de que reatores preenchidos com substrato sólido podem gerar percolado com elevada carga de sólidos (substrato e biomassa microbiana), e esta camada tem a função de retê-los, com a liberação de um efluente mais purificado. Para a adição dos pedregulhos nos lisímetros, primeiramente, foi realizado granulometria para separar apenas pedregulhos com diâmetro entre 10 e 20 mm. Em seguida, os pedregulhos foram lavados em água corrente e submetidos a solução de $\mathrm{HCl} 15 \%$ por 1 hora para limpeza. Após isso, os pedregulhos foram lavados em água destilada e secos em estufa de $100{ }^{\circ} \mathrm{C}$. Nas operações do protótipo, ao invés de pedregulhos de rio, o lisímetro foi preenchido com uma camada de pérolas de vidro (10 $\mathrm{cm}$ ), e sobre esta camada foi adicionada a massa de papel umidificado com meio mineral e suspensão de micro-organismos, com teor de umidade final de aproximadamente $80 \%$.

\subsubsection{Procedimentos para o Preenchimento dos Lisímetros}

A massa de papel utilizada nas etapas de operação dos biorreatores foi dividida igualmente em assadeiras de aço inox para o procedimento de umidificação/ inoculação do papel fragmentado. O volume total de meio mineral (vide Tabela 4.6) somado à suspensão de micro-organismos (fluido de rúmen modificado) foi dividido proporcionalmente à massa de papel em cada assadeira. A umidificação/inoculação foi realizada por meio de um spray, acionado o mesmo número de vezes para cada quadrante da assadeira preenchida com papel. Posteriormente, o conteúdo das assadeiras foi colocado em recipiente único de forma a promover a homogeneização da massa de papel úmida/inoculada a ser adicionada no biorreator.

O volume de meio mineral (modificado de ATLAS, 2005) somado à suspensão de micro-organismos (fluído de rúmen modificado para promover umidificação/ inoculação) foi calculado conforme o teor de umidade aplicado em cada operação. Para a umidade de aproximadamente 50\%, a massa de papel representava 66,67\% ST, enquanto a massa de água, 33,33\%. Para a umidade de $65 \%$, a massa de papel representava $56,67 \%$ ST e a massa de água $43,33 \%$. Por fim, para a umidade de $80 \%$, a massa de papel representava $46,66 \%$ ST e a massa de água $53,55 \%$. 
O papel foi adicionado e compactado manualmente no lisímetro.

Após a adição de papel já inoculado e com o teor de umidade inicial requerido em cada etapa, foi fluxionado $\mathrm{N}_{2}(100 \%)$ para a troca da atmosfera do headspace.

Para o instante inicial do experimento, assumiu-se o momento de fechamento dos lisímetros.

\subsubsection{Amostragens}

As alíquotas para amostragem de biogás foram coletadas diariamente durante o início da operação dos lisímetros, com várias amostragens no mesmo dia durante o período exponencial de produção de hidrogênio no headspace. Após a estabilização do volume de biogás no headspace, a amostragem foi realizada em frequência semanal. Já as alíquotas para amostragem do percolado foram coletadas diariamente a partir do dia de operação em que ocorreu liberação de percolado no biorreator. Devido aos baixos teores de umidade foi observada liberação de percolado com no mínimo 10 dias de operação. Assim, amostras sólidas foram coletadas neste período para análise de ácidos orgânicos voláteis e álcoois.

Ao final da operação, a massa residual de papel foi medida e reservada para análise de umidade e série de sólidos. Para o cálculo de consumo de papel considerou-se a massa seca de papel adicionada no início do experimento e massa seca de papel residual ao final da operação.

\subsubsection{Aspersão Meio Mineral}

Durante as operações do planejamento experimental, cujos experimentos foram delineados por um Delineamento Composto Central com 3 variáveis (Fatorial $2^{3}$ : massa de substrato; teor de umidade e temperatura - vide item 4.9.6.1), a aspersão do meio foi mantida por uma frequência de três vezes semanais, para manutenção da umidade e para fornecimento de sais minerais importantes na síntese de enzimas hidrolíticas, já que a carga de substrato orgânico foi elevada. Foi mantida esta frequência para que na operação dos reatores fosse mantido o maior tempo possível com o substrato contendo o teor de umidade inicial proposto. $\mathrm{O}$ volume de meio aspergido a cada vez foi de aproximadamente $10 \%$ do volume total utilizado para umidificar a massa de papel usada em cada condição de operação do reator (Tabela 4.6). Na primeira etapa preliminar de 
operação, a aspersão do meio mineral foi realizada diariamente, duas vezes ao dia, com volume de aproximadamente $10 \%$ do volume inicial usado para umidificar o papel, acarretando saturação da umidade do substrato muito rapidamente. Já na segunda etapa, esta frequência de aspersão foi reduzida para cada dois dias, para prolongar o período do substrato sob umidade próxima à da inicial $(80 \%)$.

Tabela 4.6 - Volume inicial de solução do meio mineral, inóculo e volume de aspersão do meio

\begin{tabular}{cccccc}
\hline & & Volume & & Volume de \\
Condições & Massa de & $\begin{array}{c}\text { Inicial } \\
\text { Solução }\end{array}$ & Teor & $\begin{array}{c}\text { aspersão do } \\
\text { Meio de }\end{array}$ & $\begin{array}{c}\text { Período de } \\
\text { Operação }\end{array}$ \\
& Peio + & Umidade $(\%)$ & cultura & $(\mathrm{d})$ \\
& $(\mathrm{g})$ & Inóculo & & $(\mathrm{mL})$ & \\
& & $(\mathrm{mL})$ & & 135 & 38 \\
Etapa I & 1080 & 1350 & 80 & 135 & 51 \\
Etapa II & 1080 & 1350 & 80 & 114 & 30 \\
R1 & 1000 & 1128 & 80 & 57 & 30 \\
R2 & 500 & 570 & 80 & 27 & 30 \\
R3 & 500 & 250 & 50 & 50 & 62 \\
R4 & 1000 & 500 & 50 & 114 & 37 \\
R5 & 1000 & 1128 & 80 & 57 & 37 \\
R6 & 500 & 570 & 80 & 27 & 37 \\
R7 & 500 & 250 & 50 & 50 & 49 \\
R8 & 1000 & 500 & 50 & 57 & 49 \\
R9 & 750 & 575 & 65 & 57 & 49 \\
R10 & 750 & 575 & 65 & & \\
\hline
\end{tabular}

4.6.5 Operação dos Lisímetros

4.6.5.1 Operação dos Lisímetros: Planejamento Experimental

O planejamento fatorial foi empregado para se avaliar as melhores condições operacionais de um sistema a ser estudado, realizando-se número menor de experimentos (DE BARROS NETO; SCARMINIO; BRUNS, 2003). Por meio do planejamento fatorial 
determinam-se quais variáveis têm efeitos estatisticamente significativos na resposta e, também como o efeito de uma variável varia com os níveis de outras variáveis. Ou seja, é possível avaliar as interações entre diferentes fatores. Essas interações são o principal componente de muitos processos de otimização, e, sem o uso dessa ferramenta estatística, importantes interações de variáveis não são detectadas e a otimização máxima do sistema pode levar mais tempo para ser alcançada (DE BARROS NETO; SCARMINIO; BRUNS, 2003; RODRIGUES, IEMMA, 2014).

As seguintes variáveis, massa de substrato (X1), umidade do substrato (X2) e temperatura de incubação (X3) foram estudadas por meio do planejamento experimental que as englobou em um delineamento composto central $2^{3}$ com repetição dos pontos centrais, a fim de se estudar a reprodutibilidade dos dados e garantir a validade estatística do modelo. Com os dados provenientes das operações dos lisímetros, e de acordo com o planejamento utilizado (Fatorial $2^{3}$ ), ajustou-se os modelos que relacionaram as respostas estudadas com as variáveis independentes especificadas por meio do Software Protimiza Experimental Design (Tabela 4.7).

Tabela 4.7 - Variáveis independentes e Variáveis Respostas do Fatorial $2^{3}$

\begin{tabular}{cccccc}
\hline \multicolumn{2}{c}{ Variáveis Independentes } & Unidade & \multicolumn{2}{c}{ Variáveis Resposta } & Unidade \\
\hline $\mathrm{X} 1$ & Massa de Papel & $\mathrm{g}$ & $\mathrm{Y} 1$ & Hidrogênio & $\mathrm{mmol}$ \\
& & & $\mathrm{Y} 2$ & Ácido Acético & $\mathrm{mg} / \mathrm{L}$ \\
$\mathrm{X} 2$ & Teor de Umidade & $\%$ & $\mathrm{Y} 3$ & Etanol & $\mathrm{mg} / \mathrm{L}$ \\
& & & $\mathrm{Y} 4$ & Metanol & $\mathrm{mg} / \mathrm{L}$ \\
\hline
\end{tabular}

$\mathrm{O}$ ajuste das funções foi feito pelo método dos mínimos quadrados, sendo a significância dos coeficientes avaliada pelo teste $\mathrm{t}$ de Student. A qualidade das correlações ajustadas foi verificada por meio do coeficiente de determinação $\left(R^{2}\right)$ (RODRIGUES, IEMMA, 2014). As respostas utilizadas para obtenção do modelo e construção das superfícies de resposta foram a produção de hidrogênio, ácido acético, etanol e metanol (Tabela 4.7). As variáveis foram investigadas sob condição de pH inicial de 5,5, e inoculação com consórcio microbiano purificado do fluido de rúmen bovino.

A matriz codificada de experimentos completa está apresentada na Tabela 4.8. Os níveis dos fatores foram codificados como -1 (baixo), 0 (ponto central) e 1 (alto). O 
tratamento dos dados foi realizado uma vez que as operações do planejamento experimental foram finalizadas.

Os lisímetros foram monitorados por meio da produção e composição do biogás, pelas características físico-químicas do percolado produzido e comportamento qualiquantitativo dos compostos orgânicos, entre eles, carboidratos, ácidos orgânicos e álcoois.

Tabela 4.8 - Operação dos Lisímetros no Planejamento Experimental

\begin{tabular}{cccc}
\hline Operação & $\begin{array}{c}\text { Massa Papel } \\
(\mathrm{g})\end{array}$ & $\begin{array}{c}\text { Teor umidade Papel } \\
(\%)\end{array}$ & $\begin{array}{c}\text { Temperatura } \\
\text { Operação } \\
\left({ }^{\circ} \mathrm{C}\right)\end{array}$ \\
\hline R1 & 1 & 1 & -1 \\
R2 & -1 & 1 & -1 \\
R3 & -1 & -1 & -1 \\
R4 & 1 & -1 & -1 \\
R5 & 1 & 1 & +1 \\
R6 & -1 & 1 & +1 \\
R7 & -1 & -1 & +1 \\
R8 & 1 & -1 & +1 \\
R9 & 0 & 0 & 0 \\
R10 & 0 & 0 & 0 \\
\hline Fatores & & Níveis & +1 \\
\hline Massa de Papel $(\mathrm{g})$ & -1 & 0 & 1000 \\
Temper de Umidade $(\%)$ & 500 & 750 & 80 \\
\hline
\end{tabular}

\subsection{Métodos Analíticos}

\subsubsection{Análises Cromatográficas}

A composição do biogás $\left(\mathrm{H}_{2}, \mathrm{~N}_{2}, \mathrm{CH}_{4}\right.$ e $\left.\mathrm{CO}_{2}\right)$ foi determinada por meio de cromatografia gasosa em cromatógrafo gasoso Shimadzu GC 2010 (Japão), contendo 
detector de condutividade térmica (TCD) e gás argônio como carreador. As temperaturas de operação do injetor, detector e coluna foram $30{ }^{\circ} \mathrm{C}, 200{ }^{\circ} \mathrm{C}$ e $230{ }^{\circ} \mathrm{C}$, respectivamente. As leituras para a determinação de biogás no headspace dos lisímetros foram efetuadas por meio da retirada de 1,0 mL de amostra da fase gasosa, utilizando seringa gastight com trava. Foi feita uma curva de calibração, usando-se uma mistura de gás padrão $\left(25 \% \mathrm{H}_{2}\right.$, $25 \% \mathrm{~N}_{2}, 25 \% \mathrm{CH}_{4}$ e $\left.25 \% \mathrm{CO}_{2}\right)$. O volume de gás foi convertido a unidade molar ( $\left.\mu \mathrm{mol}\right)$ de acordo com a temperatura e pressão medidas. A curva de calibração foi verificada estatisticamente para certificar o comportamente linear e a ausência de falta de ajuste. A partir desta curva, o biogás produzido nos lisímetros foi analisado pelo método de validade, determinando o número de mols de hidrogênio $\left(\mathrm{H}_{2}\right)$ produzido. Este método de análise também foi utilizado por Lima et al. (2013), Penteado et al. (2013) e Braga (2014).

A determinação dos ácidos orgânicos voláteis, alcoóis e acetona foi realizada por cromatografia gasosa em cromatógrafo gasoso Shimadzu GC-2010 (Japão), contendo detector de ionização de chama e amostrador automático para headspace COMBI-PAL, modelo AOC 5000. A coluna usada foi HP-INNOWAX, de $30 \mathrm{~m}$ x 0,25 mm x 0,25 um de espessura de filme. As condições operacionais foram as seguintes: temperatura do injetor de $250^{\circ} \mathrm{C}$, razão de Split igual a 1 , temperatura do forno de $35^{\circ} \mathrm{C}\left(0^{\prime}\right) 2^{\circ} \mathrm{C} / \mathrm{min}$, $38^{\circ} \mathrm{C}\left(0^{\prime}\right) 10^{\circ} \mathrm{C} / \mathrm{min}, 75^{\circ} \mathrm{C}\left(0^{\prime}\right) 35^{\circ} \mathrm{C} / \mathrm{min}, 120^{\circ} \mathrm{C}\left(1^{\prime}\right) 10^{\circ} \mathrm{C} / \mathrm{min}, 170^{\circ} \mathrm{C}$, gás de arraste foi hidrogênio, temperatura do detector a $280^{\circ} \mathrm{C}$, gás auxiliar $\mathrm{N}_{2}$ a $30 \mathrm{~mL} / \mathrm{min}$; gás sintético a $300 \mathrm{~mL} / \mathrm{min}$, e hidrogênio a $30 \mathrm{~mL} / \mathrm{min}$. As condições do amostrador automático de headspace COMBI-PAL, AOC 5000, foram as seguintes: seringa de 2,5 $\mathrm{mL}$, temperatura da seringa a $90{ }^{\circ} \mathrm{C}$, volume injetado de $400 \mu \mathrm{L}$, temperatura de incubação da amostra a $100{ }^{\circ} \mathrm{C}$, tempo de incubação da amostra de 21 minutos (ADORNO; HIRASAWA; VARESCHE, 2014).

O preparo da amostra consistiu em utilizar 2,0 mL de amostra (diluída ou não) a ser analisada, além da adição de $1,0 \mathrm{~g}$ de $\mathrm{NaCl}, 100 \mu \mathrm{L}$ de solução de ácido crotônico, 70 $\mu \mathrm{L}$ de solução de isobutanol e $200 \mu \mathrm{L}$ de solução de ácido sulfúrico $2 \mathrm{M}$.

Todas as análises de biogás e da composição/ quantificação de compostos orgânicos em meio líquido foram feitas em duplicata. 
4.7.2 Parâmetros físico-químicos

As análises físico-químicas realizadas nas amostras de percolado produzido durante a fermentação acidogênica do papel nos biorreatores foram as seguintes: Demanda Química de Oxigênio (DQO), pH, série de sólidos e série de alcalinidade de acordo com $o$ Standard Methods for the Examination of Water and Wastewater (APHA; AWWA; WEF, 2005). A análise de carboidratos totais no percolado foi realizada pelo método colorimétrico fenol-ácido sulfúrico (DUBOIS et al., 1956, modificado por HERBERT; PHILIPPS; STRANG, 1971), utilizando glicose como padrão. A frequência de realização de análises químicas do efluente para monitoramento do reator está exposta na Tabela 4.9.

Durante as etapas de obtenção do consórcio microbiano celulolítico e fermentativo a partir do fluido de rúmen bovino, foram realizadas também análises de sulfeto de hidrogênio dissolvido em meio líquido a fim de detectar a presença/concentração deste composto nas condições de incubação aplicadas. Para tanto, foi utilizada a metodologia colorimétrica de azul de metileno, segundo APHA; AWWA; WEF, (2005).

Todas as análises físico-químicas foram realizadas em duplicata de amostras.

\section{lisímetros}

Tabela 4.9 - Análises de Monitoramento do percolado após sua liberação nos

\begin{tabular}{cccc}
\hline Parâmetros & Método & Frequência & Referência \\
\hline $\begin{array}{c}\text { Carboidratos totais/ } \\
\text { solúvel }\end{array}$ & Colorimétrico & 3X semana & DUBOIS et al., 1956 \\
DQO total/ solúvel & Colorimétrico & 3X semana & APHA; AWWA; WEF, \\
& & & 2005 \\
$\mathrm{pH}$ & Potenciométrico & 5 X semana & APHA; AWWA; \\
& & & WEF, 2005 \\
& & & DILLALO e \\
& & & ALBERTSON(1961) \\
Alcalinidade & Titulométrico & modificada por \\
& & & RIPLEY; ROYLE, \\
& & & CONVERSE (1985) \\
& & & Continua
\end{tabular}


continuação

\begin{tabular}{cccc}
\hline Parâmetros & Método & Frequência & Referência \\
\hline Metabólitos & & & ADORNO; \\
Orgânicos em Meio & Cromatográfico & 3X semana & HIRASAWA; \\
Líquido & & & VARESCHE, 2014 \\
Série de Sólidos & Gravimétrico & 1x a cada 15 dias & APHA; AWWA; \\
& & & WEF, 2005 \\
\hline
\end{tabular}

\subsection{Estimativa do consumo de papel}

Por meio da diferença da massa seca de papel mensurada, por gravimetria, no início e no final do período de operação dos lisímetros, e excluindo-se as massas de papel retiradas ao longo da operação (monitoramento), pôde-se estimar a massa de papel resultante ao final da operação. Essa massa provavelmente se refere à quantidade de papel consumida. Para se considerar a massa relativa à fração aquosa do substrato (umidade), realizou-se análise de Sólidos Totais em triplicata para o papel no início e final da operação, detectando-se assim seu teor de umidade, e excluindo-o da massa total papel mais umidade.

\subsection{Análises Microbiológicas}

\subsubsection{Estocagem de amostra e Extração de DNA}

As amostras selecionadas para avaliação da diversidade genética por meio de sequenciamento massivo foram o fluido de rúmen in natura (F.N.), fluido de rúmen purificado (F.P.), e amostras coletadas após a finalização da operação dos lisímetros R2 (operado a $35^{\circ} \mathrm{C}$ ), R5 (operado a $55^{\circ} \mathrm{C}$ ) e R9 (operado a $45^{\circ} \mathrm{C}$ ). Essas amostras foram selecionadas a fim de se realizar uma análise comparativa detalhada das populações microbianas mais abundantes no fluido de rúmen in natura e fluido de rúmen após a etapa de enriquecimento seletivo. Objetivou-se avaliar quais foram as populações prevalecentes no fluido de rúmen enriquecido, o qual foi usado como inóculo em todas as condições de operação dos lisímetros. Dentre todas as condições de operação impostas nos lisímetros, com variação de temperatura de incubação, massa de papel adicionada e teor de umidade 
do papel, escolheu-se analisar a amostra de micro-organismos dos lisímetros com maior produção de hidrogênio e/ou metabólitos para cada temperatura estudada $\left(35,45\right.$ ou $55^{\circ}$ C).

Para obter amostra de micro-organismos representativa dos lisímetros ao final da operação foram coletados entre 100 e $300 \mathrm{~g}$ de papel umidificado, que foi colocado em 200 mL de água ultra-purificada e posteriormente macerado. Após a maceração, formouse uma solução concentrada de micro-organismos, que foi centrifugada a $4^{\circ} \mathrm{C}$ por 8.500 rpm durante 6 minutos. Após a centrifugação, as amostras de micro-organismos foram lavadas (3x) com tampão PBS (vide item 4.2.4), seguida pela centrifugação a $4^{\circ} \mathrm{C}$ por 8.500 rpm durante 10 minutos. Em seguida, os pellets foram armazenados a $-20{ }^{\circ} \mathrm{C}$ para posterior extração de DNA.

A extração do DNA genômico foi realizada de acordo com metodologia modificada de Griffiths, Whiteley e O'Donnell (2000), pelo uso de pérolas de vidro (glass beads). Para a extração do DNA foram utilizados solução de fenol tamponado com Tris e clorofórmio. Seguindo o protocolo de extração, em tubo Falcon de $15 \mathrm{~mL}$ contendo 0,5 $\mathrm{g}$ de biomassa úmida foi adicionado $0,3 \mathrm{~g}$ de glass beads, $1 \mathrm{~mL}$ de tampão PBS, $1 \mathrm{~mL}$ de fenol tamponado com Tris e $1 \mathrm{~mL}$ de clorofórmio. Em seguida, a amostra foi homogeneizada em vórtex por 25 segundos e centrifugada por 10 minutos a $4^{\mathrm{O}} \mathrm{C}$ e 6.000 rpm. Após a primeira centrifugação, transferiu-se $1 \mathrm{~mL}$ de sobrenadante (contendo DNA) a um eppendorf e adicionou-se $1 \mathrm{~mL}$ de fenol, esta amostra foi rapidamente homogeneizada em vórtex e centrifugada nas condições citadas acima. Após a segunda centrifugação, retirou-se $800 \mu \mathrm{L}$ de sobrenadante, colocou-os em outro eppendorf e adicionou-se neste o mesmo volume de clorofórmio. Novamente, a amostra foi rapidamente homogeneizada em vórtex e centrifiugada nas condições citadas. Esse procedimento foi realizado por 3 vezes consecutivas. Por fim, aproximadamente $400 \mu \mathrm{L}$ de sobrenadante contendo o DNA foram transferidos para outro eppendorf e a amostra com DNA foi armazenada $\mathrm{a}-20{ }^{\circ} \mathrm{C}$.

\subsubsection{PCR/DGGE}

As comunidades microbianas do Domínio Bacteria foram analisadas utilizandose amostras do inóculo fluido de rúmen enriquecido e dos lisímetros R1 a R10 a fim de verificar a influência das condições de operação na estrutura da comunidade. Para o 
DGGE (Eletroforese em Gel de Gradiente Desnaturante) do Domínio Bacteria foi utilizado o set de primer 968FGC - 1401R (NUBEL et al., 1996) (Tabela 4.10) para amplificação dos fragmentos de DNA e as condições da corrida de PCR estão descritas na Tabela 4.11. Os produtos da PCR foram aplicados em gel de poliacrilamida 8\% (massa/voluma) em TAE 1X, com gradiente linear desnaturante (ureia e formamida) variando de 45 a $65 \%$. As condições usadas foram voltagem constante de $75 \mathrm{~V}$ e temperatura de $60^{\circ} \mathrm{C}$, durante 16 horas. A imagem do gel foi analisada e capturada em equipamento Eagle Eye II (Stratagene, La Jolla, CA, USA) com iluminação UV. O perfil de bandas do gel de DGGE foi analisado no software Bionumerics 2.5. O coeficiente de similaridade e dendrograma foram construídos segundo o coeficiente de Pearson e algoritmo UPGMA (unweighted pair group method with arithmetic averages), respectivamente.

Tabela 4.10 - Iniciadores para Dominio Bacteria

\begin{tabular}{|c|c|c|c|}
\hline Domínio & Iniciadores & Sequência 5' $\rightarrow 3^{\prime}$ & Referência \\
\hline \multirow{10}{*}{ Bacteria } & \multirow{7}{*}{968 F GC } & $5^{\prime}-$ AAC GCG & \multirow{10}{*}{ NUBEL et al. (1996) } \\
\hline & & AAG AAC CTTAC & \\
\hline & & CGC CCG GGG & \\
\hline & & CGC GCC CCG & \\
\hline & & GGC GGG GCG & \\
\hline & & GGG GCA CGG & \\
\hline & & GGGG - 3' & \\
\hline & & $5^{\prime}-$ CGG TGT & \\
\hline & $1401 \mathrm{R}$ & GTA CAA GAC & \\
\hline & & $\mathrm{CC}-3^{\prime}$ & \\
\hline
\end{tabular}

Tabela 4.11 - Condições utilizadas na PCR para o DGGE

\begin{tabular}{cccccccc}
\hline $\begin{array}{c}\text { Domí- } \\
\text { nio }\end{array}$ & $\begin{array}{c}\text { Pré- } \\
\text { Desnatura- } \\
\text { ção }\end{array}$ & $\begin{array}{c}\mathbf{N n}^{\mathbf{0}} \\
\text { de } \\
\text { Ciclo } \\
\text { s }\end{array}$ & $\begin{array}{c}\text { Desnatura- } \\
\text { ção }\end{array}$ & $\begin{array}{c}\text { Anelamen- } \\
\text { to }\end{array}$ & $\begin{array}{c}\text { Exten- } \\
\text { são }\end{array}$ & $\begin{array}{c}\text { Final de } \\
\text { Exten- } \\
\text { são }\end{array}$ & $\begin{array}{c}\text { Resfria- } \\
\text { mento }\end{array}$ \\
\hline $\begin{array}{c}\text { Bacteri } \\
a\end{array}$ & $94^{\circ} \mathrm{C}$ & 35 & $94^{\circ} \mathrm{C}$ & $63^{\circ} \mathrm{C}$ & $72^{\circ} \mathrm{C}$ & $72^{\circ} \mathrm{C}$ & $4^{\circ} \mathrm{C}$ \\
$\begin{array}{c}\text { NUBE } \\
\begin{array}{c}\text { L et al., } \\
1996)\end{array}\end{array}$ & 5 min & - & $1 \mathrm{~min}$ & $1 \mathrm{~min}$ & $1 \mathrm{~min}$ & $5 \mathrm{~min}$ & - \\
\hline
\end{tabular}


4.9.3 Sequenciamento do gene rRNA 16S - Plataforma Illumina (Miseq)

O sequenciamento massivo de amplicons do gene rRNA 16S foi realizado por meio da Plataforma Illumina Miseq no Laboratótio de Biotecnologia Animal, Departamento de Zootecnia (ESALQ/USP Piracicaba, Brasil), usando o equipamento Miseq (Illumina). Para tanto, foram enviadas amostras de DNA genômico purificado em concentração mínima de $50 \mathrm{ng} / \mu \mathrm{L}$ e relação 260/280 1,8-2,0. A quantificação e análise da pureza foram realizadas em espectrofotômetro Nanodrop 2000. A integridade do DNA extraído foi verificada por eletroforese em gel de agarose $0,8 \%$ em TAE 1 X e sua purificação foi feita por meio do kit Illustra GFX PCR DNA and Gel Band Purification (GE Healthcare). As regiões V3 e V4 (KLINDWORTH et al., 2013) do gene rRNA 16S foi amplificada, utilizando-se os iniciadores CCTACGGGNGGCWGCAG16S (S-DBact-0341-b-S-17) e GACTACHVGGGTATCTAATCC (S-D-Bact-0785-a-A-21). Foi gerado um fragmento de aproximadamente $400 \mathrm{pb}$.

\subsubsection{Análise das sequências}

O processamento inicial das sequências foi realizado pela equipe especializada em Bioinformática do Laboratório de Biotecnologia Animal, Departamento de Zootecnia (ESALQ/USP Piracicaba/SP). A obtenção dos dados brutos foi feita pelo software CASAVA 1.8.2 fornecido pela Illumina, que faz o base call dos dados brutos e os transforma em reads no formato fastq acompanhados dos scores de qualidade phred. Os reads foram visualizados por meio do programa FastQC (www.bioinformatics.bbsrc.ac.uk/projects/). A filtragem dos reads de baixa qualidade, sequência de adaptadores e vetores foi realizada pelo programa Seqyclean (https://bitbucket.org/izhbannikov/seqyclean), utilizando como cutoff as bases com qualidade inferior a 24 QScore; e a base de dados de contaminantes usada foi a Univec (http://www.ncbi.nlm.nih.gov/VecScreen/UniVec.html). Após a filtragem, os reads com tamanho inferior a $65 \mathrm{pb}$ foram removidos.

Para a análise das sequências obtidas na Plataforma Illumina (Miseq) foram utilizadas as ferramentas disponíveis no site $R D P$ 's Pipeline, fazendo-se o uso de base de dados para os Domínios Bacteria e Archaea (http://pyro.cme.msu.edu; COLE et al., 2014). O pipeline usado foi o do pacote QIIME (Qiime-Quantitative insights into microbial ecology) versão 1.9 (CAPORASO et al., 2010a) em 3 etapas: 
1) Concatenação dos reads paired-end.

2) Filtragem, procura e identificação de OTUs (Unidades Taxonômicas Operacionais). Nessa etapa o programa também realizou uma nova montagem de reads que não tiveram hit com a base de dados e procurou hit contra todas as bases disponíveis.

3) Análises de rarefação, alfa e beta diversidade. Para essas análises, levou-se em consideração a profundidade de cobertura da amostra com menos reads para utilizar o parâmetro sampling-depth de forma adequada.

A estimativa da riqueza das amostras microbianas coletadas do fluido de rúmen in natura, fluido de rúmen enriquecido e dos lisímetros R2, R5 e R9 foi realizada por meio dos estimadores Chao1 e Rarefação.

O método Chao1 possibilita estimar o número total de espécies numa determinada comunidade a partir dos dados amostrais; permite comparar dados com método e esforço de coletas diferentes. Enfim, este método estima a riqueza total, utilizando o número de espécies representadas por 1 ou 2 indivíduos nas amostras, as chamadas singletons e doubletons, respectivamente. Portanto, esse estimador considera as espécies raras. A rarefação consiste em calcular o número esperado de espécies em cada amostra para um tamanho de amostra padrão. Uma ressalva é que a rarefação deve ser usada apenas para amostras obtidas com métodos padronizados, e em hábitats iguais ou similares.

Em relação às medidas de diversidade alfa, os índices levam em conta tanto a uniformidade (equitabilidade) quanto a riqueza de espécies, sendo chamados também de índices de heterogeneidade. Tanto o aumento do número de espécies, quanto o aumento da uniformidade das abundâncias eleva a diversidade. Um exemplo é o índice de Shannon-Wiener, que é o mais utilizado, e dá maior peso para as espécies raras. Outros índices utilizados pertencem ao grupo das medidas de dominância, uma vez que dão mais peso para as espécies comuns, sendo o índice de Simpson (1-D) o mais usado. Enquanto o índice de Shannon-Wiener é fortemente influenciado pela riqueza, o índice de Simpson é influenciado pela equitabilidade (Tabela 4.12). 
Tabela 4.12 - Parâmetros de alfa-diversidade

\begin{tabular}{ll}
\hline Índices de Diversidade & \multicolumn{1}{c}{ Valores } \\
\hline Shanon-Wiener $(H)$ & Valores de $0-\infty$. Quanto maior o índice, \\
& maior o número de táxons na comunidade \\
& amostrada. \\
& Valores de 0 a 1.0 representa nenhuma \\
Simpson $(1-D)$ & diversidade e 1 representa total diversidade. \\
& Valores de 0 a 1.0 indica a presença uniforme \\
Dominância (D) & de todos os táxons e 1 indica o domínio de um \\
& táxon na comunidade microbiana. Ou seja, \\
& quanto menor o $D$, maior a diversidade da \\
& amostra.
\end{tabular}

Fonte: DELFORNO (2014).

Sobre as medidas de diversidade beta, o índice de Bray-Curtis é de uso frequente, por ser disponível na maioria dos pacotes estatísticos e varia entre 0 (similaridade) e 1 (dissimilaridade). É fortemente influenciado pelas espécies dominantes, de forma que as espécies raras acrescentam muito pouco ao seu valor. Seu cálculo é baseado nas diferenças absolutas e nas somas das abundâncias de cada espécie nas duas amostras comparadas (BRAY, CURTIS, 1957). Vários autores preferem definir esta medida como Similaridade, fazendo 1-D. As comparações entre as composições de comunidades distintas podem ser realizadas baseadas em dados qualitativos ou quantitativos das espécies inventariadas. Isso permite a construção de dendrogramas de classificação e ordenação de comunidades de acordo com suas semelhanças.

A determinação dos clusters (OTUs) foi realizada pelo Uclust (EDGAR, 2010), usando-se índice de similaridade de $97 \%$ entre as sequências, e o alinhamento das sequências por meio do Pynast (CAPORASO et al., 2010b). A classificação taxonômica das sequências representativas de cada OTU foi dada por meio do Ribosomal Database Project (RDP) (WANG; MU, YU, 2007), com limite de confiança (Threshold confidence) mínimo de 50\%. As singletons, OTUs com uma sequência/read, não foram consideradas.

Com base no número de sequências, foram construídos os Diagramas de Venn, pela ferramenta Bioinformatics \& Evolutionary Genomics (http://bioinformatics.psb.ugent.be/webtools/Venn/). 


\section{RESULTADOS E DISCUSSÃO}

\subsection{Cultivo e Enriquecimento do Fluido de Rúmen para Obtenção de Consórcio Microbiano Celulolítico e Fermentativo}

O metabolismo microbiano é diretamente relacionado às condições físicas e químicas do ambiente. Os fatores ambientais influenciam significativamente o crescimento de uma população microbiana, alterando a síntese de enzimas e, consequentemente, a rota metabólica a ser seguida. Dessa forma, o controle de fatores essenciais, como presença de macro e micronutrientes, vitaminas, além de $\mathrm{pH}$ e temperatura, é essencial para favorecer o crescimento de micro-organismos que exerçam metabolismos de interesse biotecnológico.

Para o favorecimento de populações celulolíticas e (ou) fermentativas, no presente estudo, foram testados três meios de cultura quimicamente definidos selecionados por favorecerem o crescimento destas bactérias. O meio de Ho et al. (2011) foi usado, porque esses autores utilizaram-no na purificação de fluido de rúmen para obtenção de inóculo celulolítico e fermentativo a fim de obter produção de hidrogênio a partir dessa biomassa. O meio para conservação de Ruminococcus albus (Ruminococcus albus Medium, descrito em ATLAS, 2005) foi selecionado para o teste; uma vez que essa espécie já foi anteriormente descrita como bactéria celulolítica e fermentativa e utilizada em trabalhos de produção de hidrogênio a partir de resíduos celulósicos, inclusive o papel (NTAIKOU; KOUTROS, KORNAROS, 2009). Por último, foi selecionado o meio CAM (Cellulose Anaerobe medium - ATLAS, 2005) para favorecimento das bactérias anaeróbias celulolíticas.

Em análise comparativa da composição dos três meios de cultivo testados notouse que cinco reagentes eram comuns, e sempre utilizados para o crescimento de bactérias celulolíticas: sulfato de amônio, sulfato de magnésio, fosfato monobásico de potássio, fosfato bibásico de potássio e cloreto de cálcio. Pôde-se observar que sais de sulfato, adicionados como macro ou micronutrientes, eram presentes na composição dos três meios, principalmente no meio CAM.

Para favorecer o crescimento de micro-organismos celulolíticos, o uso de fontes de energia prontamente fermentáveis, que não necessitam de hidrólise com celulase, tais 
como, glicose, xilose e sacarose, por exemplo, não devem ser considerados. Portanto, durante todo o processo de cultivo e favorecimento das populações celulolíticas e fermentativas do fluído de rúmen foi utilizado papel sulfite limpo e fragmentado como substrato orgânico.

Em relação aos meios de cultura, foi observado que nos reatores com meio CAM (ATLAS, 2005), a hidrólise de papel foi mais rápida, com produção de hidrogênio detectável $(0,1 \mathrm{mmol})$ e concentração de metano abaixo do nível de detecção da curva durante 15 dias de incubação. Já para o meio para cultivo de Ruminococcus albus (ATLAS, 2005), a hidrólise de papel foi menos intensa, com produção de metano ( 0,1 mmol) e concentração de hidrogênio abaixo do limite de detecção da curva analítica. Por último, para o meio de Ho et al. (2011) verificou-se evolução de metano (0,15 mmol), sem detecção de hidrogênio. A partir dessas considerações optou-se por usar o meio CAM nas etapas seguintes de enriquecimento do fluído de rúmen a um consórcio celulolítico e fermentativo.

O uso de papel como fonte de carbono e energia acarreta baixa concentração inicial de DQO solúvel, já que o aumento desta se dá com a hidrólise de papel ao longo do período de incubação. Aparentemente, o uso do meio CAM, que consistiu de vários compostos de sulfato somado a essa reduzida DQO solúvel inicial (40 mg/L) promoveu o favorecimento de outras populações consumidoras de hidrogênio, a saber bactérias redutoras de sulfato $(\mathrm{BRS})$ em relação às arqueias metanogênicas. No enriquecimento com meio CAM, usando fluído de rúmen solubilizado como inóculo foi detectado 15,5 mg/L de sulfeto no meio líquido, após 15 dias de incubação. Além disso, pôde-se observar escurecimento do meio líquido devido à precipitação de sulfeto metálico no reator.

Arqueias metanogênicas e BRS catalisam os estágios terminais da degradação anaeróbia de compostos orgânicos. Ambas as populações competem pelo hidrogênio e, também pelo ácido acético. Arqueias metanogênicas tendem a ser consumidoras dominantes de hidrogênio e acetato em condições de sulfato limitante (LENS et al., 1998). Entretanto, na presença de níveis não limitantes de sulfato, as BRS se sobressaem em relação às arqueias metanogênicas, tanto em ambientes naturais, quanto em sistemas engenheirados (DURAND et al., 2010; RASKIN; RITTMANN, STAHL, 1996).

Após uma série de operação (4 ciclos de operação) de reatores em bateladas foi observada diminuição do volume de metano no headspace, usando fluído de rúmen como inóculo e meio CAM. Portanto, foram realizadas diluições seriadas para enriquecimento do consórcio microbiano essencialmente celulolítico e fermentativo. Nos ensaios de 
diluições seriadas, o fluido de rúmen já enriquecido em meio CAM foi diluído até $10^{-10}$. Os melhores resultados foram para as diluições $10^{-4}, 10^{-5}$ e $10^{-7}$, no que diz respeito à degradação de papel, ausência de metano no headspace e manutenção da quantidade de $\mathrm{H}_{2}$ produzida no headspace, ou seja, provavelmente sem consumo deste gás.

Para as diluições $10^{-1}$ e $10^{-2}$ foi observada degradação visual de papel e produção de hidrogênio, com volume máximo de 0,40 e 0,45 $\mathrm{mmol} \mathrm{H}_{2}$, respectivamente. Porém, houve diminuição da concentração hidrogênio no headspace e produção de metano durante o período de incubação (50 dias), com máxima produção de 0,4 e 0,13 mmol $\mathrm{CH}_{4}$. Já para as diluições $10^{-3}, 10^{-6}, 10^{-9}$ e $10^{-10}$ verificou-se degradação visual de papel e produção de hidrogênio com valores máximos de 0,$52 ; 0,87 ; 0,36$ e $0,57 \mathrm{mmol} \mathrm{H}_{2}$, respectivamente, em 30 dias. Para essas diluições não se verificou metano, porém, ao longo do período de incubação, não se constatou estabilização da produção de hidrogênio no headspace. Em contrapartida, a estabilização da concentração de hidrogênio foi observada para as diluições $10^{-4}, 10^{-5}$ e $10^{-7}$ ao longo de 50 dias de incubação, cujos valores máximos de hidrogênio observados foram de 0,98; 2,2 e 0,65 $\mathrm{mmol} \mathrm{H}_{2}$, respectivamente para $10^{-4}, 10^{-5}$ e $10^{-7}$.

Apesar do comportamento da produção de hidrogênio ter sido diferente para as diluições, a degradação visual de papel foi observada na grande maioria das diluições, o que provavelmente indicou favorecimento das populações celulolíticas nas condições de cultivo utilizadas, além de provável redução das populações metanogênicas e sulfetogênicas. A redução da produção de metano ao longo das diluições foi acompanhada da diminuição da concentração de sulfeto de $24,3 \mathrm{mg} / \mathrm{L}$ para diluição $10^{-1}$ a 3,6 e $2,5 \mathrm{mg} / \mathrm{L}$ para $10^{-5}$ e $10^{-7}$, respectivamente.

Como os consórcios microbianos são compostos de populações que exercem metabolismos variados, os meios de fermentação devem ser projetados para eliminar receptores de elétrons (sulfato, nitrato e ferro) que usam hidrogênio como doadores de elétrons para a respiração (SAADY, 2013). Portanto, as condições de cultivo propostas para o meio CAM (ATLAS, 2005) foram modificadas para o enriquecimento do consórcio obtido nas diluições $10^{-4}, 10^{-5}$ e $10^{-7}$, a fim de suprimir o metabolismo sulfetogênico. Para tanto, foi retirada a solução redutora de sulfeto de sódio, além da substituição da maioria dos sais de sulfato por sais de cloreto. Assim, a disponibilidade de sulfato no meio foi reduzida de 1,1 para 0,03 g/L. A composição do meio reformulado está descrita na seção Material e Métodos. A cultura microbiana purificada, enriquecida 
em meio CAM reformulado, foi utilizada como inóculo nas etapas de operação do lisímetro.

\subsection{Operação do Protótipo de Lisímetro: monitoramento}

A fermentação acidogênica do papel limpo com elevada carga de substrato foi avaliada quanto ao seu comportamento e eficiência por meio do monitoramento do headspace e efluente líquido (percolado). O percolado é formado quando a capacidade de saturação dos sólidos é excedida, ocorrendo lixiviação com o conseqüente carreamento de produtos metabólicos, micro-organismos, matéria orgânica solubilizada e matéria orgânica sólida presente na massa de resíduos saturados (BALDOCHI, 1997).

Nos lisímetros, o percolado formado pela saturação do papel foi analisado para avaliar a atividade microbiana celulolítica e fermentativa, por meio de produtos resultantes da fermentação acidogênica, como carboidratos solúveis, ácidos voláteis e solventes orgânicos, e das alterações físico-químicas de $\mathrm{pH}$, alcalinidade, DQO, ST e STV. A cinética de produção de hidrogênio e gás carbônico foi avaliada pela composição e produção de biogás nos lisímetros.

Foram realizadas duas operações no protótipo de lisímetro para a verificação e ajuste da configuração final do lisímetro, além das condições operacionais impostas, com o intuito de obter rendimentos satisfatórios de hidrogênio e ácidos orgânicos a partir de papel umidificado. No protótipo de lisímetro ocorreu a fermentação de substrato semissólido, já que o papel não estava submerso em água, mas continha teor de umidade de $80 \%$.

A produção de hidrogênio no protótipo iniciou-se após um dia de operação (abaixo do limite de detecção do método), sendo crescente nos dias consecutivos, com pico após 7 dias de operação (Figura 5.1). Entretanto, após a detecção do pico aos 7 dias, com aproximadamente $20 \mathrm{mmol} \mathrm{de}_{2}$ no headspace, observou-se decréscimo gradativo de sua quantidade. A partir do $10^{\circ}$ dia de operação verificou-se número de mol de hidrogênio no headspace abaixo do limite de detecção do método, seguindo assim até o final da operação (Figura 5.1). Não foi observado segundo pico de produção de hidrogênio durante o período de operação desta Etapa. Apesar de ter sido detectado consumo de hidrogênio, a operação da etapa 1 foi mantida para o monitoramento do 
percolado, já que se verificou produção de ácidos orgânicos voláteis, considerados subprodutos de interesse tecnológico.

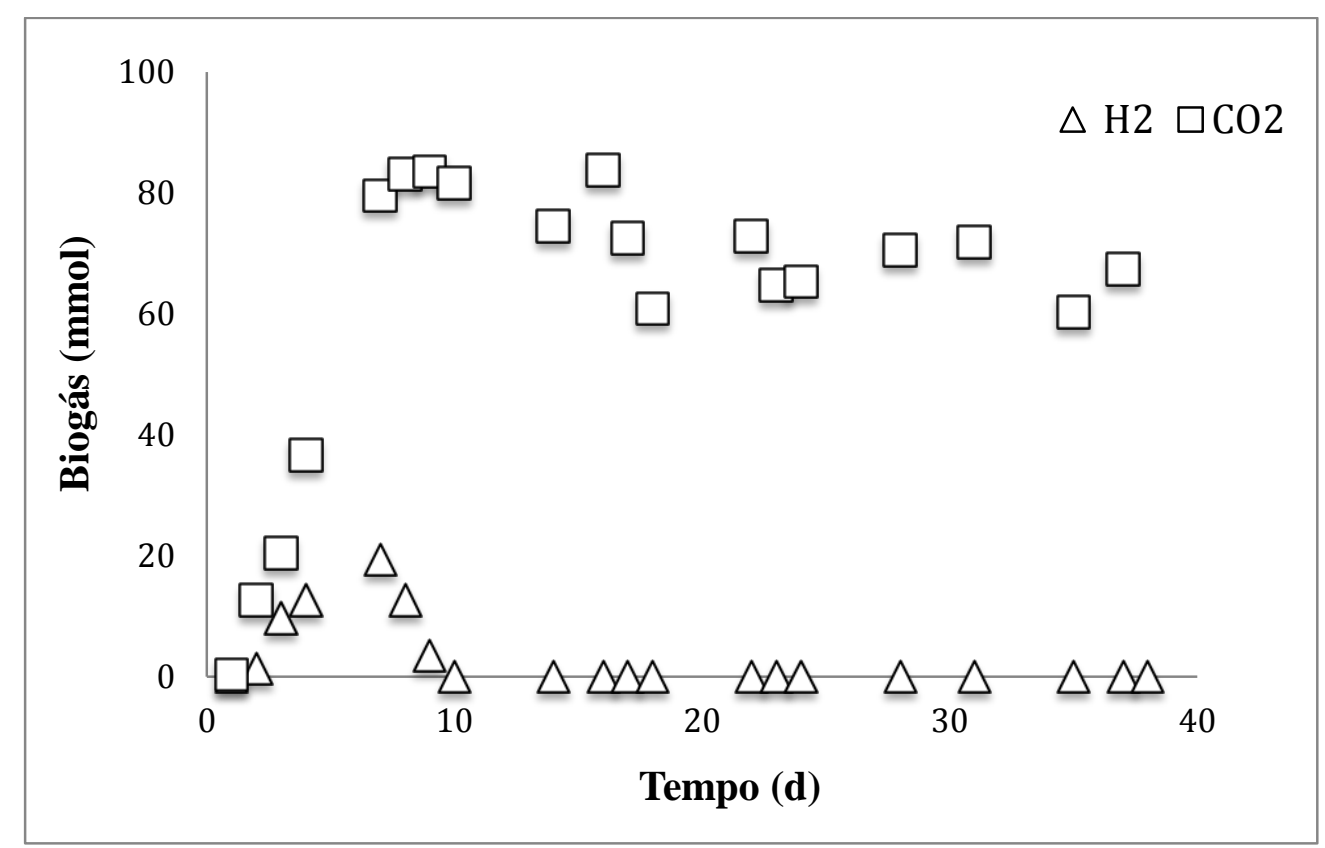

Figura 5.1 - Número de mol de hidrogênio e gás carbônico no headspace do lisímetro - ETAPA I

Ajustando-se os dados de produção de hidrogênio ao modelo de Gompertz modificado verificou-se potencial máximo de produção de hidrogênio de 19,5 mmol e velocidade de produção de $0,9 \mathrm{mmol} / \mathrm{dia}$; a produção iniciou-se após 2,82 dias de incubação $\left(\mathrm{R}^{2}=0,9991\right)$.

O gás carbônico foi produzido concomitantemente ao hidrogênio, porém verificou-se maior produção, com valor máximo de aproximadamente $90 \mathrm{mmol}$. Assim como para o gás hidrogênio, a produção de gás carbônico foi observada desde o segundo dia de operação do reator até o nono dia. A partir dessa data, verificou-se $70 \mathrm{mmol}$ de gás carbônico no headspace, sem variação ao longo de todo o período de operação desta etapa (Figura 5.1). Portanto, os gases $\mathrm{H}_{2}$ e $\mathrm{CO}_{2}$ foram produzidos, ou foram transferidos para a fase gasosa, apenas nos 9 primeiros dias de operação. Não foi observada produção de metano ao longo do período de operação.

Por meio desses resultados, pôde-se verificar que sob as condições impostas no lisímetro houve degradação do papel pelo fluido de rúmen após enriquecimento seletivo, mesmo este substrato estando em estado semissólido, e crescimento da biomassa microbiana medido indiretamente pela produção de hidrogênio, gás carbônico e 
compostos orgânicos solúveis (ácidos orgânicos voláteis), já que não havia disponibilidade de nenhuma outra fonte de carbono no sistema operacional.

Entretanto, como era um consórcio microbiano, faziam parte também da sua composição outras bactérias consumidoras de hidrogênio, que provavelmente conseguiram se estabelecer nas condições experimentais, o que acarretou em operação insatisfatória para obtenção de hidrogênio, porém com possibilidade de recuperação de ácidos orgânicos.

Durante todo o período de operação do lisímetro da Etapa I foi observado consumo de hidrogênio. Consumo de hidrogênio em reatores anaeróbios usando-se inóculo pré-tratado foi observado após longo período de incubação (LUO et al., 2011). Segundo esses autores, a inibição e/ou eliminação de micro-organismos consumidores de hidrogênio por diluições ou pré-tratamentos de inóculo é diminuída ao longo do período de incubação do consórcio microbiano, e podem ser eficientes apenas a curto-prazo.

Na Etapa I, a primeira detecção de produção de percolado ocorreu após 3 dias de operação e, a partir desse dia, foram monitoradas, além da produção de hidrogênio, a produção de compostos orgânicos solúveis, DQO, carboidratos totais solúveis, série de sólidos totais, $\mathrm{pH}$ e série de alcalinidade.

Por meio da análise dos compostos orgânicos solúveis, nos primeiros dias de operação foi observado aumento crescente das concentrações de ácido acético, ácido butírico e etanol, atingindo 5.700, 1.450 e $2.300 \mathrm{mg} / \mathrm{L}$, respectivamente, no nono dia de operação do reator (Figura 5.2 A;C). Os três compostos citados estão relacionados com a produção de hidrogênio de acordo com as seguintes reações químicas mencionadas a seguir (KARADAG, PUHAKKA, 2010; SOLOMON et al., 1995; THAUER; JUNGERMANN, DECKER, 1977):

Ác. acético: $\mathrm{C}_{6} \mathrm{H}_{12} \mathrm{O}_{6}+4 \mathrm{H}_{2} \mathrm{O} \rightarrow 2 \mathrm{CH}_{3} \mathrm{COO}^{-}+2 \mathrm{HCO}_{3}{ }^{-}+4 \mathrm{H}_{2}+2 \mathrm{H}+$

Ác. butírico: $\mathrm{C}_{6} \mathrm{H}_{12} \mathrm{O}_{6}+2 \mathrm{H}_{2} \mathrm{O} \rightarrow \mathrm{CH}_{3} \mathrm{CH}_{2} \mathrm{CH}_{2} \mathrm{COO}^{-}+2 \mathrm{HCO}_{3}{ }^{-}+3 \mathrm{H}^{+}+2 \mathrm{H}_{2}$ (6)

Etanol: $\mathrm{C}_{6} \mathrm{H}_{12} \mathrm{O}_{6}+\mathrm{H}_{2} \mathrm{O} \rightarrow 2 \mathrm{H}_{2}+2 \mathrm{CO}_{2}+\mathrm{C}_{2} \mathrm{H}_{4} \mathrm{O}_{2}+\mathrm{C}_{2} \mathrm{H}_{6} \mathrm{O}$ 


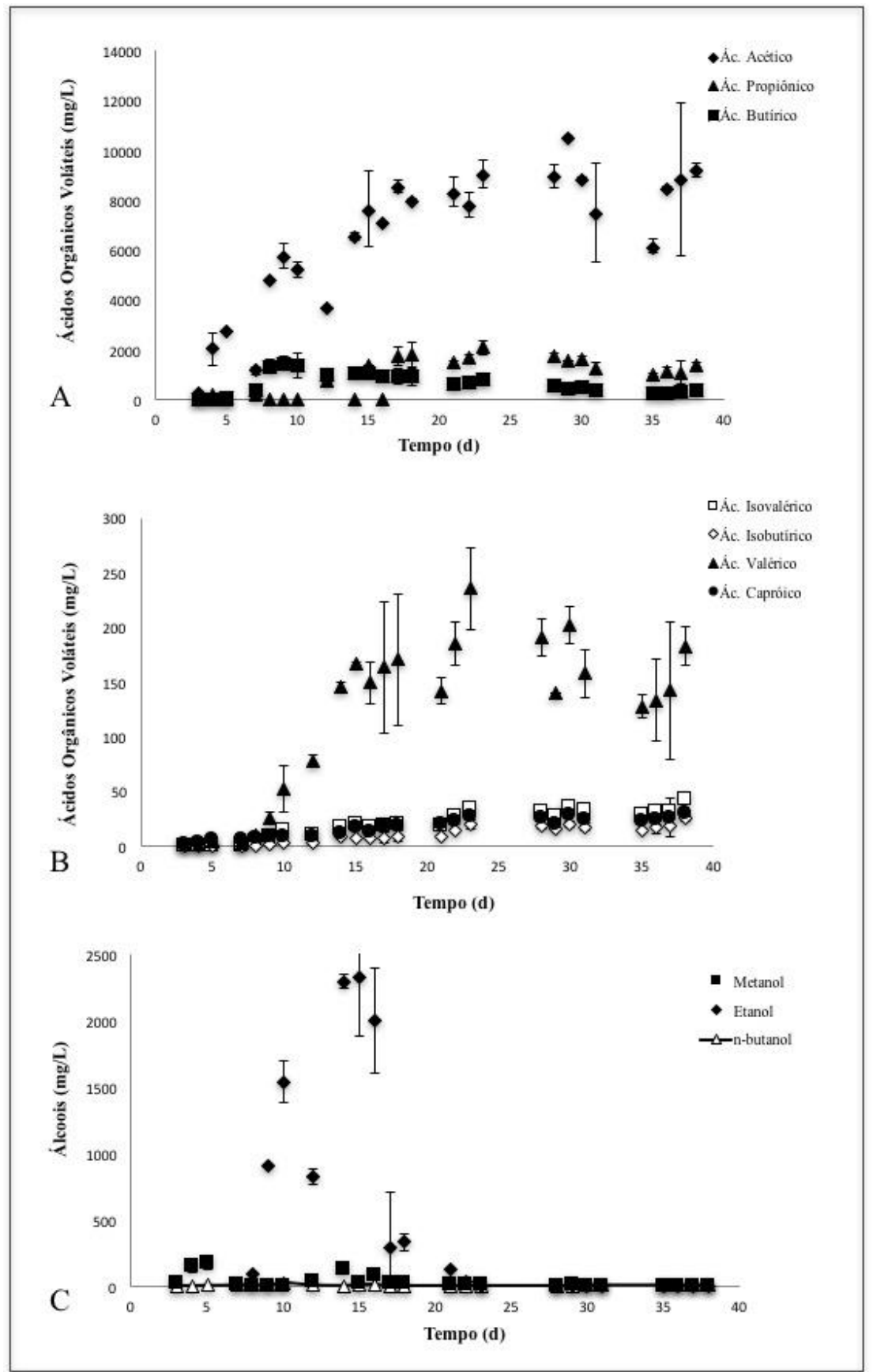

Figura 5.2 - Compostos orgânicos solúveis no percolado - ETAPA I. (A) Ácido acético, butírico e propiônico; (B) Ácido isobutírico, isovalérico, valérico e caproico; (C) Álcoois: metanol, etanol e n-butanol

A partir do $10^{\circ}$ dia de operação, verificou-se redução da quantidade de hidrogênio no headspace, e observou-se diminuição gradativa de ácido butírico e etanol, que respectivamente foram detectados em $300 \mathrm{mg} / \mathrm{L}$ e abaixo do limite de detecção, respectivamente, no último dia de operação (Figura $5.2 \mathrm{~A} ; \mathrm{C}$ ). O etanol não foi mais detectado desde o $17^{\circ}$ dia de operação (Figura 5.2C). Em contrapartida, a partir do $10^{\circ}$ dia observou-se aumento gradual de ácidos acético, propiônico, valérico, isovalérico e 
capróico. Observou-se para esses ácidos concentrações máximas de 10.500, 2.000, 235, 40 e 29 mg/L, respectivamente, ao longo do período de operação da Etapa 1 (Figura $5.2 \mathrm{~B})$.

Verificou-se valores elevados de DQO para o percolado ao longo do período de operação, os quais foram correspondentes às concentrações elevadas de compostos orgânicos solúveis. Nos 9 primeiros dias de operação do reator, foram observados os maiores valores de DQO, provavelmente relacionados ao somatório de carboidratos solúveis liberados da hidrólise de papel em meio líquido, e aos compostos orgânicos solúveis resultantes da atividade fermentativa (Figura 5.3A). A partir deste período, verificou-se $10.000 \pm 1,97 \mathrm{mg} / \mathrm{L}$ de DQO para o percolado.

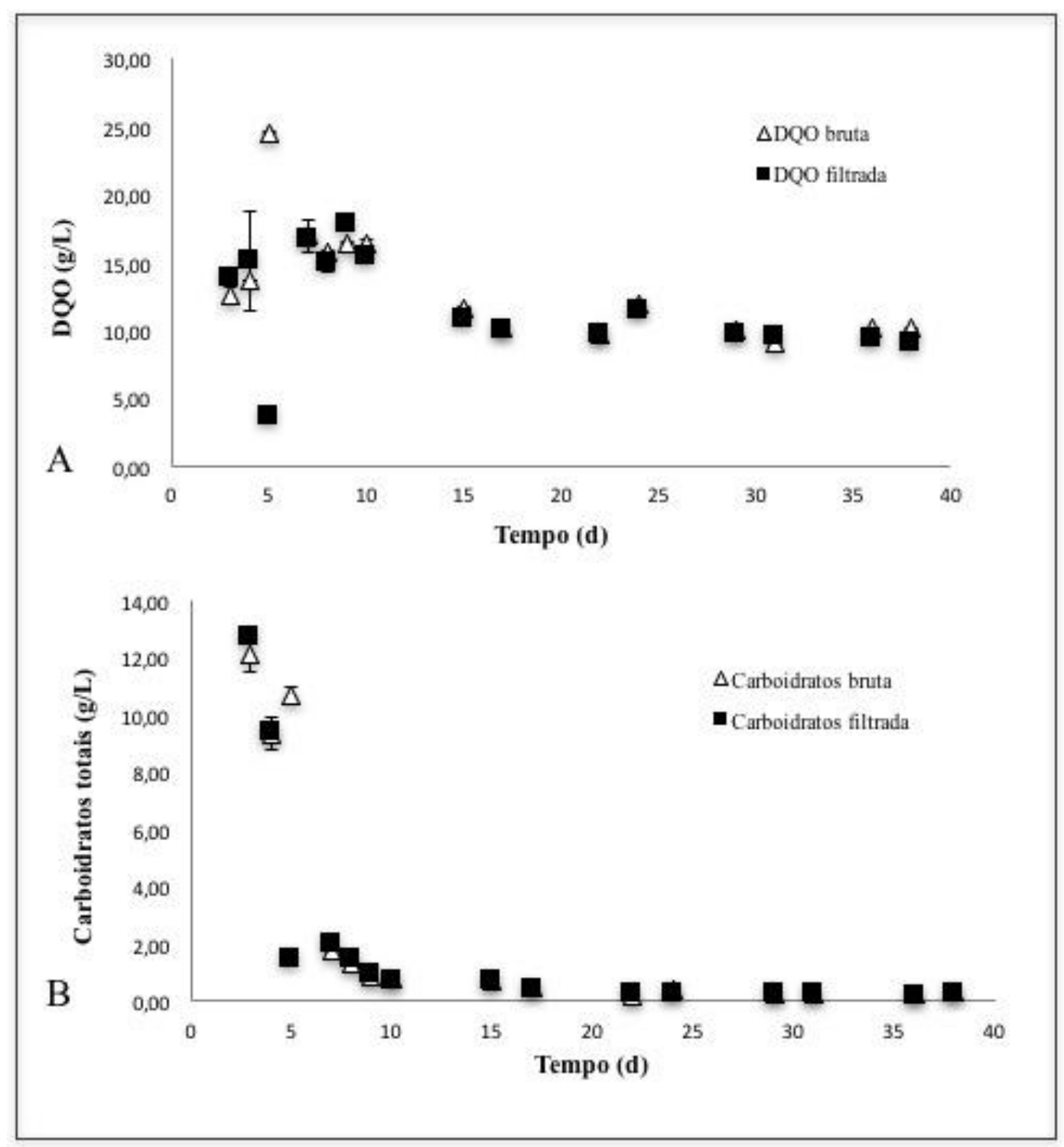

Figura 5.3 - (A) DQO (bruta e filtrada) e (B) Carboidratos totais solúveis (bruta e filtrada) no percolado - ETAPA I 
Os valores de carboidratos solúveis totais detectados no efluente reforçam essa hipótese de que houve hidrólise do papel apenas nos nove primeiros dias de operação do lisímetro, referente ao período de evolução de hidrogênio no headspace. No terceiro dia de operação verificou-se máxima concentração de carboidratos solúveis totais (amostra filtrada), de aproximadamente $12.500 \mathrm{mg} / \mathrm{L}$. A partir do $9^{\circ}$ dia de operação observou-se diminuição para 41,5 $27 \mathrm{mg} / \mathrm{L}$ até o final da operação (Figura 5.3B).

A massa de papel úmido no início da operação foi de $2.430 \mathrm{~g}$, com teor de umidade de $77 \%$ (aproximadamente $80 \%$ ), enquanto a massa de substrato ao final da operação foi de 2.884,6 g, com teor de umidade de $100 \%$. Portanto, a massa seca de papel no início e final da operação foi de $1.050 \mathrm{~g}$ e $960 \mathrm{~g}$, respectivamente, e a massa de papel seca retirada ao longo da operação foi de 7,66 g. Considerando esses valores, o consumo estimado de papel foi de aproximadamente $80 \mathrm{~g}$.

Verificou-se pequena variação de $\mathrm{pH}(6,33 \pm 0,27)$ do percolado em relação ao pH inicial no lisímetro da Etapa I, ao longo do período de operação (Tabela 5.1). Foi observado aumento da alcalinidade; ou seja, de $0,4 \mathrm{~g} / \mathrm{L}$ no quarto dia a 4,0 g/L no último dia de operação (Tabela 5.1). O lisímetro foi inoculado com 1,3 $\pm 0,85 \mathrm{~g} \mathrm{STV/L}$, e ao final da operação observou-se 5,9 \pm 0,53 g STV/L (Tabela 5.1).

A partir dos resultados obtidos, aparentemente a rápida evolução do hidrogênio no headspace, com aumento da pressão parcial desse gás, pode ter levado à inibição de bactérias hidrolíticas, levando à redução da hidrólise de papel e produção de hidrogênio e mudança de metabolismo por parte dos micro-organimos do consórcio utilizado como inóculo.

\section{Etapa I}

Tabela 5.1 - Parâmetros físico-químicos de monitoramento do percolado da

\begin{tabular}{ll}
\hline Parâmetro & Valor \\
\hline pH inicial & 7,0 \\
pH percolado* & $6,33 \pm 0,27$ \\
Alcalinidade parcial Inicial $\left(\mathrm{mg} / \mathrm{L} \mathrm{CaCO}_{3}\right)$ & 2,06 \\
Alcalinidade parcial percolado $\left(\mathrm{mg} / \mathrm{L} \mathrm{CaCO}_{3}\right)^{*}$ & $360 \pm 153$ \\
Alcalinidade total Inicial $(\mathrm{mg} / \mathrm{L} \mathrm{CaCO}$ & 2.712 \\
Alcalinidade total percolado $(\mathrm{g} / \mathrm{L} \mathrm{CaCO})^{*}$ & $3,2 \pm 1,46$ \\
Sólidos Totais Voláteis Inicial $(\mathrm{mg} / \mathrm{L})$ & $1,3 \pm 0,85$ \\
Sólidos Totais Voláteis percolado $(\mathrm{mg} / \mathrm{L})^{*}$ & $5,9 \pm 0,53$ \\
\hline
\end{tabular}

*Valores médios do período de operação 
Destaca-se que, provavelmente, o aumento da alcalinidade no reator pode também ter influenciado na alteração do metabolismo de produção de hidrogênio para consumo deste gás e de compostos orgânicos solúveis, como por exemplo, por acidogênese, acetogênese e homoacetogênese. A partir do $7^{\circ}$ até $11^{\circ}$ dia de operação do lisímetro verificou-se que a concentração de ácido acético mais do que dobrou, ou seja, de 1.002 mg/L para 3.600 mg/L. A partir da reação estequiométrica de produção de hidrogênio via ácido acético seria esperado que o rendimento de hidrogênio aumentasse com a produção deste ácido, mas não foi o observado, reforçando a hipótese de homoacetogênese (SAADY, 2013).

A diminuição das concentrações de ácido butírico e etanol ao longo do período de operação pode estar relacionada à acetogênese. Ademais, foi observado aumento das concentrações de ácido propiônico, valérico e capróico, o que acarreta o consumo de hidrogênio (SAADY, 2013).

A ocorrência de homoacetogênese foi quase certa durante a Etapa I, porém não se observou alteração do gás carbônico no headspace, até o final da operação. Portanto, a adição de bicarbonato de sódio no meio de cultura, provavelmente proporcionou condição satisfatória para a homoacetogênese. Dessa forma, na metade do período de operação da Etapa I, a concentração de bicarbonato de sódio foi reduzida para $0,5 \mathrm{~g} / \mathrm{L}$, mantendo-se o $\mathrm{pH}$ inicial de 7,0, como uma tentativa de minimizar a homoacetogênese e restabelecer a produção de hidrogênio. Porém, isso não foi observado.

Na Etapa II de operação, algumas mudanças foram realizas a fim de se obter a hidrólise de papel e produção de hidrogênio, e minimizar o consumo deste gás. Nesta fase, o bicarbonato de sódio foi retirado do meio mineral.

Na Etapa II verificou-se que a produção de hidrogênio iniciou no segundo dia de operação, atingindo, no terceiro dia, o valor máximo obtido na Etapa I; ou seja de aproximadamente $19 \mathrm{mmol}$, e no quarto dia de operação este valor foi para $34 \mathrm{mmol}$ (Figura 5.4).

Ajustando-se os dados de produção de hidrogênio ao modelo de Gompertz modificado, pôde-se observar que a produção de hidrogênio foi mais rápida e maior na etapa II em relação à Etapa I. O tempo para início da produção de $\mathrm{H}_{2}$ reduziu de 2,82 dias (Etapa I) para 1,89 dias (Etapa II). Todavia, verificou-se que a velocidade de produção quase dobrou de $0,9 \mathrm{mmol} / \mathrm{dia}$ na etapa I para $1,7 \mathrm{mmol} /$ dia na etapa II. Portanto, observou-se em menor período de operação, valor máximo de produção. O potencial máximo de produção de hidrogênio calculado por meio do modelo também foi maior, ou 
seja, de 34,61 mmol $\left(\mathrm{R}^{2}=0,9998\right)$. Entretanto, redução gradativa de hidrogênio no headspace também foi mais rápida em relação à Etapa I. No sétimo dia de operação verificou-se diminuição pela metade do valor máximo obtido de hidrogênio no headspace com redução gradativa até valores abaixo do limite de detecção do método.

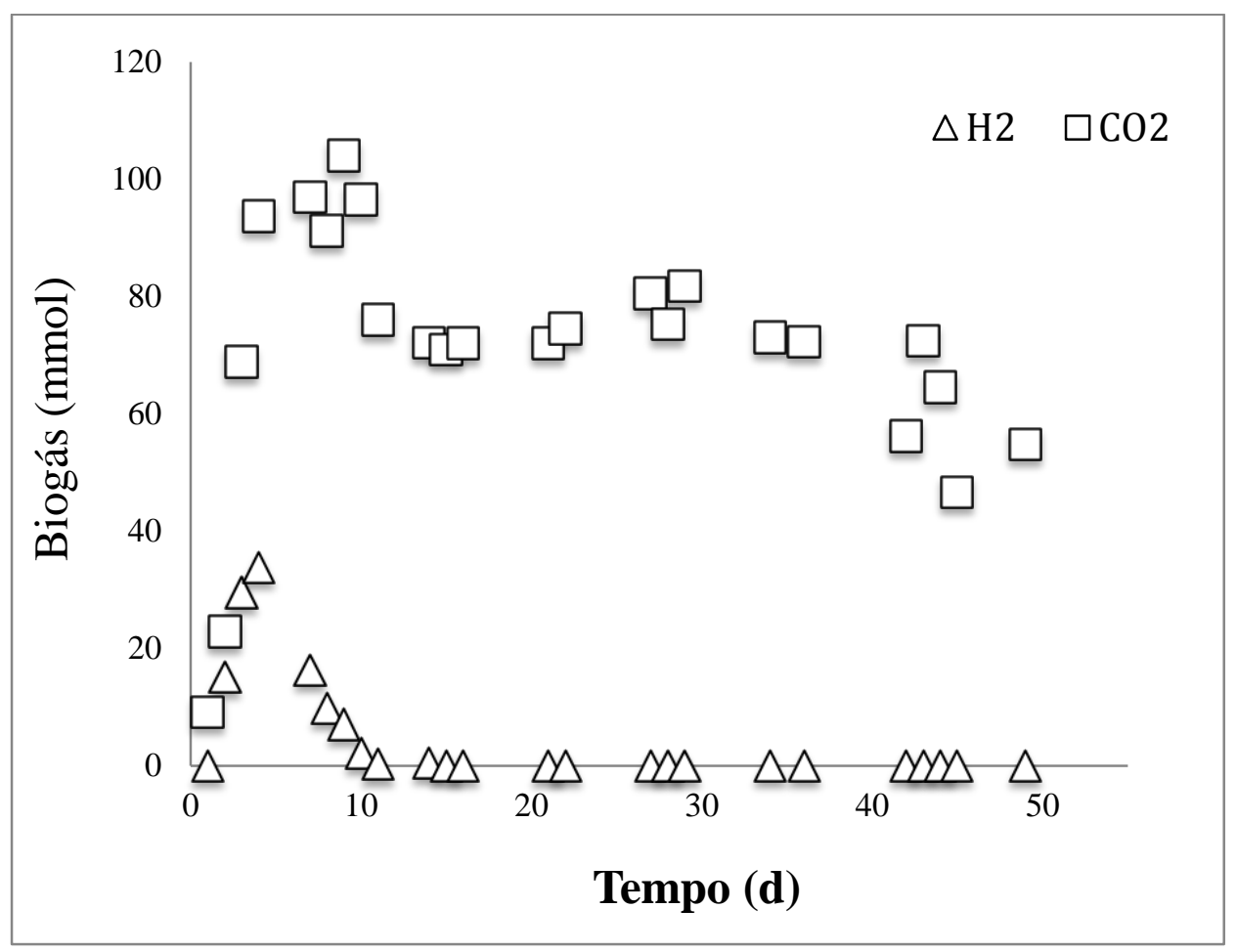

Figura 5.4 - Número de mol de hidrogênio e gás carbônico no headspace do lisímetro - ETAPA II

Como observado na Etapa I, o gás carbônico também foi produzido concomitantemente com o gás hidrogênio, com valor máximo de $94 \mathrm{mmol}$ no quarto dia de operação (Figura 5.4). A partir desta data, verificou-se manutenção aproximadamente constante do número de mol de $\mathrm{CO}_{2}$ ao longo do período de operação do reator (Figura 5.4). Na Etapa II, semelhante à Etapa I, não houve produção de metano em todo o período de operação analisado.

O monitoramento de compostos orgânicos solúveis no percolado do reator foi possível após 10 dias de operação apenas, uma vez que a vazão de aspersão de meio de cultura no reator foi reduzida em relação à Etapa 1, ou seja, foi necessário tempo mais longo para a formação do percolado. 
Após 10 dias de operação, verificou-se concentrações elevadas de ácido acético, ácido butírico e etanol de, 7.300, 2.300 e 1.700 mg/L, respectivamente (Figura 5.5A, C). Assim, esses compostos foram produzidos concomitantemente com hidrogênio e gás carbônico e, provavelmente, resultaram das vias citadas nas equações 5, 6 e 7 . 


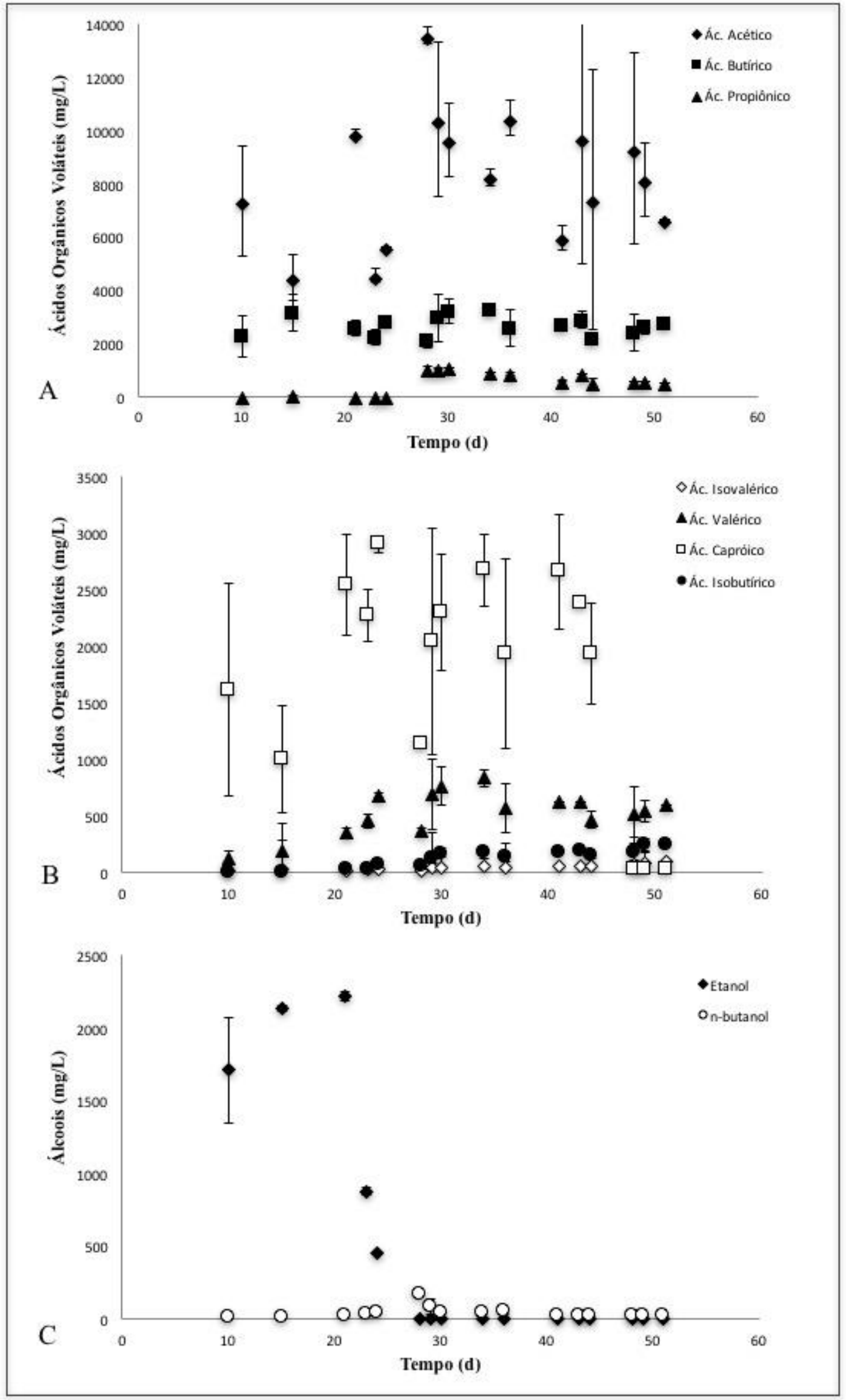

Figura 5.5 - Compostos orgânicos solúveis no percolado - ETAPA II. (A) Ácido acético, butírico e propiônico; (B) Ácido isobutírico, isovalérico, valérico e caproico; $(C)$ Álcoois: etanol e n-butanol 
Verificou-se produção de etanol ao longo de vinte dias de operação, em concentração máxima de $2.200 \mathrm{mg} / \mathrm{L}$, e semelhante ao observado na Etapa 1, foi consumido gradativamente até não ser mais detectado no percolado a partir do $28^{\circ}$ dia (Figura 5.5C). Em contrapartida, não se observou variação para o ácido butírico ao longo do período de monitoramento do percolado, cujos valores observados foram entre 2.000 e $3.000 \mathrm{mg} / \mathrm{L}$ (Figura 5.5A), semelhante ao observado na Etapa I. Os ácidos propiônico, valérico, isovalérico e capróico foram detectados em concentrações elevadas, ainda maiores do que aquelas detectadas na Etapa I. Para esses ácidos, as concentrações máximas obtidas foram 1.000, 760, 80 e $2.900 \mathrm{mg} / \mathrm{L}$, respectivamente (Figura 5.5B).

Foi observada concentração elevada de ácido acético (Figura 5.5A) a partir do décimo dia de operação, provavelmente referente a homoacetogênese e acetogênese. Nesta etapa, aparentemente o consumo de hidrogênio também se deu, tanto pela homoacetogênese, quanto por outros metabolismos, tal como a produção dos ácidos propiônico, valérico e capróico.

Em ambas as Etapas, portanto, o hidrogênio pareceu ter sido consumido pelas vias de homoacetogênese, e pelas vias de produção de ácido propiônico, valérico e capróico. $\mathrm{Na}$ etapa 2, por sua vez, o consumo de hidrogênio na forma de equivalentes redutores pareceu ter sido o principal, visto as elevadas concentrações de ácidos propiônico, valérico e capróico. As reações de formação dos ácidos capróico e valérico a partir de ácido propiônico e butírico, respectivamente, consomem 6 mol de $\mathrm{H}_{2}$ (WANG; MU, YU, 2007).

O monitoramento de análises físico-químicas como DQO, carboidratos solúveis e alcalinidade só foi possível após 21 dias de operação, quando obteve-se volume maior de percolado. Foi observada concentração elevada de DQO do percolado ao longo do período de operação (Figura 5.6A), provavelmente devido às altas concentrações de compostos orgânicos solúveis detectados durante todo o período. 


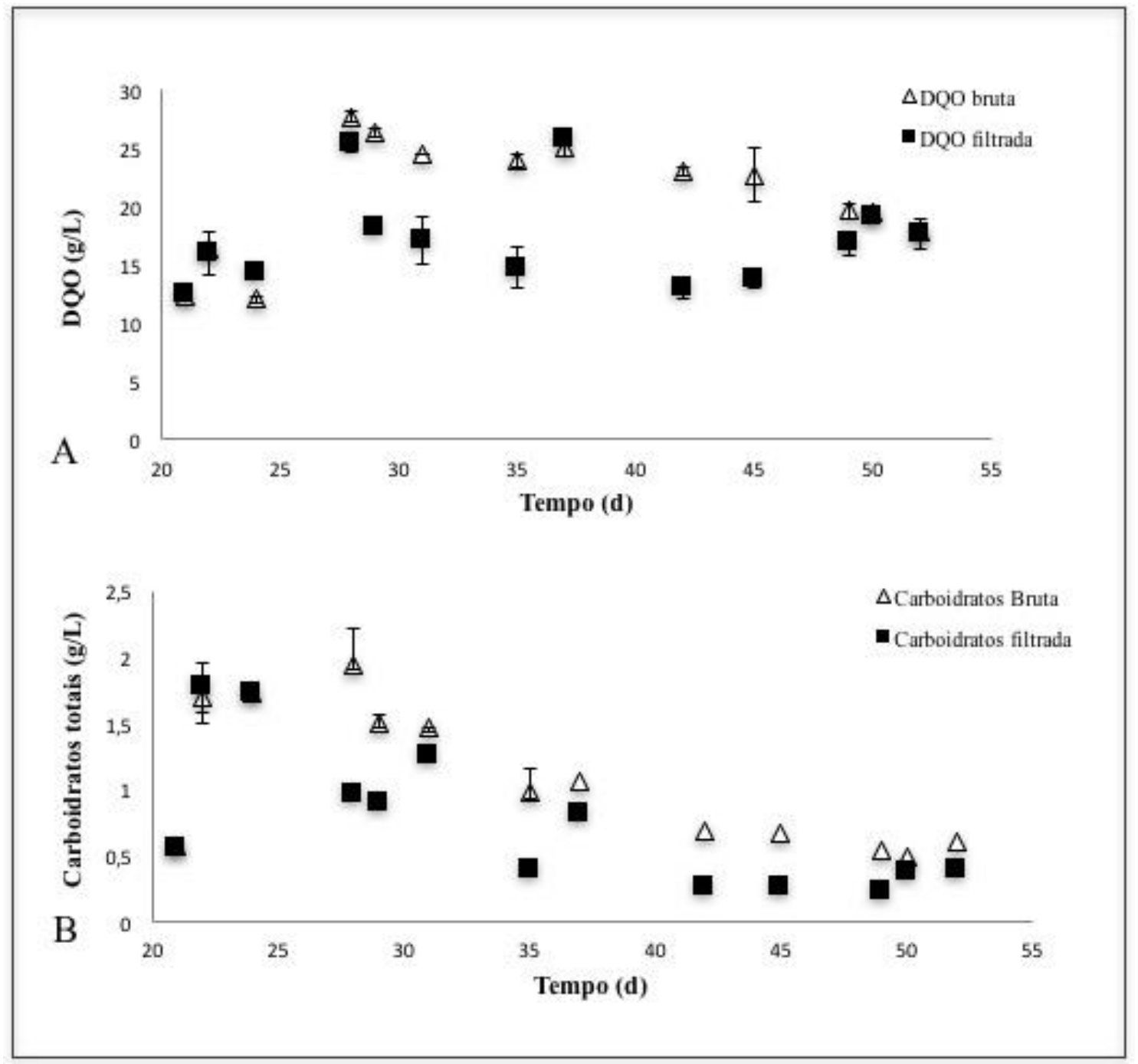

Figura 5.6 - (A) DQO (bruta e filtrada) e (B) Carboidratos totais solúveis (bruta e filtrada) do percolado - ETAPA II

Os carboidratos totais solúveis foram detectados já em concentrações mais baixas, como observado no mesmo intervalo do período de operação da Etapa I (Figura 5.6B). Isso, provavelmente, foi devido ao fato das análises terem sido realizadas apenas a partir do $21^{\circ}$ dia de operação, ou seja, provavelmente não foram detectadas as concentrações de carboidratos solúveis referentes ao período de hidrólise de papel e evolução de hidrogênio (até o $10^{\circ}$ dia).

Nesta etapa, a massa de substrato adicionada no início da operação foi também de $2.430 \mathrm{~g}$, com teor de umidade de $78 \%$ (aproximadamente $80 \%$ ), e a massa de substrato ao final da operação foi de 2.638,34 g, com teor de umidade de $100 \%$. A massa seca de papel no início e no final da operação foi de $1.080 \mathrm{~g}$ e 878,34 g, respectivamente, e a 
massa de papel seca retirada ao longo da operação foi de 5,16 g. Portanto, o consumo estimado de papel foi de aproximadamente 196,5 g.

A alteração do pH inicial de 7,0 (etapa 1) para 6,5 (etapa 2) não evitou a alteração da via metabólica de produção para consumo de hidrogênio, por parte das bactérias do consórcio microbiano, tampouco evitou a produção elevada de alcalinidade ao longo do período de operação, que aumentou de $74 \mathrm{mg} / \mathrm{L}$ no $21^{\circ}$ dia a $515 \mathrm{mg} / \mathrm{L}$ ao final da operação (Tabela 5.2). Tal como observado na etapa 1 foi detectada alcalinidade crescente no percolado e, provavelmente, por isso verificou-se a manutenção do gás carbônico do headspace intacta ao longo do período de operação. Apesar da ausência de bicarbonato de sódio no meio de cultura, verificou-se $5,97 \pm 0,15$ para o $\mathrm{pH}$ do percolado, com ligeira diminuição em relação ao pH inicial (6,5) (Tabela 5.2). O lisímetro foi inoculado com 2,4 \pm 0,56 g STV/L, e ao final da operação observou-se 9,7 \pm 0,4 g STV/L (Tabela 5.2).

\section{Tabela 5.2 - Parâmetros físico-químicos do percolado da Etapa II}

\begin{tabular}{lc}
\hline Parâmetro & Valor \\
\hline $\mathrm{pH}$ inicial & 6,5 \\
$\mathrm{pH}$ efluente & $5,95 \pm 0,15$ \\
Alcalinidade parcial Inicial $\left(\mathrm{mg} / \mathrm{L} \mathrm{CaCO}_{3}\right)$ & 1.708 \\
Alcalinidade parcial percolado $\left(\mathrm{mg} / \mathrm{L} \mathrm{CaCO}_{3}\right)$ & $421 \pm 153$ \\
Alcalinidade total Inicial $\left(\mathrm{mg} / \mathrm{L} \mathrm{CaCO}_{3}\right)$ & 2.305 \\
Alcalinidade total percolado $(\mathrm{g} / \mathrm{L} \mathrm{CaCO}$ & $3)$ \\
Sólidos Totais Voláteis Inicial $(\mathrm{g} / \mathrm{L})$ & $5,78 \pm 0,8$ \\
Sólidos Totais Voláteis percolado $(\mathrm{g} / \mathrm{L})$ & $2,4 \pm 0,56$ \\
\hline
\end{tabular}

A partir da comparação dos resultados obtidos nas Etapas I e II, pode-se concluir que as alterações de pH, exclusão de bicarbonato de sódio do meio mineral, e diminuição do fluxo de meio mineral por aspersão, foram favoráveis à hidrólise de papel, produção de hidrogênio, já que houve aumento da produção de hidrigênio na Etapa II, crescimento da biomassa microbiana e produção de ácidos orgânicos solúveis. No entanto, tais modificações não foram eficientes para minimizar os micro-organismos consumidores de hidrogênio, e tanto a homoacetogênese quanto à acidogênese foram observadas em ambas as Etapas I e II. Esses metabolismos estão diretamente ligados ao consumo de hidrogênio, de acordo com Saady (2013). A partir disso, buscou-se na literatura alternativas de 
alteração nas condições ambientais que pudessem favorecer a hidrólise de papel e evolução de hidrogênio no headspace por período maior de operação.

$\mathrm{O}$ pH é um fator operacional importante durante a produção fermentativa de hidrogênio, uma vez que interfere no crescimento e metabolismo dos micro-organismos produtores e consumidores de hidrogênio. As velocidades de crescimento dos diversos grupos tróficos das culturas anaeróbias variam com o $\mathrm{pH}$. Por exemplo, o pH ótimo para crescimento dos micro-organismos acidogênicos é de 5,9 (KHANAL et al., 2003), enquanto dos acetogênicos e metanogênicos é em torno de 7,0 (GUJER, ZEHNDER, 1983). Durante a produção de hidrogênio a partir da glicose em cultivos em batelada mesofílicos foi descrito que a redução do $\mathrm{pH}$ diminuiu a taxa de consumo de hidrogênio em 33\% (SAADY et al. 2012). Especificamente, nesse trabalho com operação de lisímitros (etapa I e II) verificou-se uma produção ligeiramente maior de hidrogênio na Etapa II comparada à Etapa I, entretanto, não foi suficiente para inibir o consumo de hidrogênio até que este fosse ausente no headspace.

A temperatura de incubação também é um fator que interfere diretamente na atividade metabólica dos micro-organismos, influenciando diretamente a via de degradação dos substratos orgânicos. Luo e colaboradores (2011) realizaram cultivos em batelada em temperatura mesofílica $\left(37^{\circ} \mathrm{C}\right)$ e termofílica $\left(55^{\circ} \mathrm{C}\right)$, testando $\mathrm{pH}$ iniciais de 5,5 e 7,0 para ambas temperaturas. Para as duas condições mesofílicas e termofílica em pH 7,0, os autores observaram consumo de hidrogênio devido à produção de ácido láctico, homoacetogênese, além de metanogênese após longo-prazo de cultivo. Apenas para o cultivo termofílico em $\mathrm{pH}$ 5,5 os autores detectaram ausência dos metabolismos que acarretam consumo de hidrogênio, inclusive homoacetogênese, e maiores rendimentos de hidrogênio dentre as condições estudadas. Para os autores, a combinação de temperatura termofílica e pH 5,5 foi necessária para a inibição da homoacetogênese.

Segundo a literatura, a produção de hidrogênio é mais estável em temperaturas termofílicas. DONG et al. (2011) descreveram estabilidade na produção de hidrogênio durante período de operação de 310 dias em temperatuara termofílica, usando sacarose como substrato. Em estudo de produção de hidrogênio a partir de resíduo alimentício foi obtido rendimento maior em temperatura termofílica, de $0,8 \mathrm{~mol} \mathrm{H}_{2} / \mathrm{mol}$ hexose, em comparação com temperatura mesofílica, de 0,05 mol H2/ mol hexose, em pH 5,5 (SHIN; YOUN, KIM, 2004).

O uso de fluido de rúmen como inóculo em cultivos termofílicos para degradação de celulose e produção de hidrogênio já foi anteriormente realizado com sucesso 
(NISSILA et al., 2011). O fluido de rúmen contém, além de outros gêneros fermentativos importantes, espécies do gênero Clostridium, descritas como produtoras eficientes de hidrogênio, tanto em temperatura mesofílica, quanto em temperatura termofílica (BOTTA, 2012; HO et al., 2011). Em suma, a partir do estudo da literatura, somado à análise dos resultados das etapas preliminares de operação, considerou-se testar também a variável temperatura de incubação no planejamento experimental (fatorial $2^{3}$ ) e estabelecer o pH inicial de 5,5 em todas as operações.

\subsection{Operação do Lisímetro no modelo de Planejamento Experimental (Fatorial $2^{3}$ )}

Em temperatura mesofílica de $35^{\circ} \mathrm{C}$, foram operados os lisímetros R1, R2, R3 e R4. Os lisímetros R1 (1000 g) e R2 (500 g) foram operados com teor de umidade de 78 e $85 \%$, respectivamente, enquanto os lisímetros R3 (500 g) e R4 (1000 g), com teor de umidade de 48 e $47 \%$, respectivamente. O papel usado como substrato em cada um dos lisímetros R1, R2 e R3 foi umidifcado e inoculado pelo mesmo afluente, cujos parâmetros físico-químicos estão descritos na Tabela 5.3. Para o R4, o papel foi umidificado e inoculado com afluente similar também descrito na Tabela 5.3 Os lisímetros R1, R2 e R3 foram operados simultaneamente, enquanto R4 foi operado após a finalização dos primeiros, devido à disponibilidade de três unidades de lisímetros e uma câmara de incubação. Os lisímetros R1, R2 e R3 foram operados por 30 dias, enquanto o lisímetro R4 por 62 dias, a fim de avaliar possível crescimento microbiano após tempo de incubação maior, em relação àquele aplicado para R3, também iniciado com teor de umidade de $50 \%$.

Em temperatura termofílica de $55^{\circ} \mathrm{C}$, foram operados os lisímetros $\mathrm{R} 5, \mathrm{R} 6, \mathrm{R} 7 \mathrm{e}$ R8. Os lisímetros R5 (1000 g) e R6 (500 g) foram operados com teor de umidade de 81 e $82 \%$, respectivamente, enquanto os lisímetros R7 (500 g) e R8 (1000 g), com teor de umidade de 55 e $56 \%$, respectivamente. O papel usado como substrato em cada um dos lisímetros R5, R6 e R7 foi umidifcado e inoculado pelo mesmo afluente, cujos parâmetros físico-químicos estão descritos na Tabela 5.3 Já para o R8, o papel foi umidificado e inoculado com afluente similar também descrito na Tabela 5.3 Os lisímetros R5, R6 e R7 foram operados simultaneamente, enquanto $\mathrm{R} 8$ foi operado após a finalização dos primeiros, devido à disponibilidade de três unidades de lisímetros e uma câmara de 
incubação. Os lisímetros R5, R6 e R7 foram operados por um período de 37 dias, ao passo que $\mathrm{R} 8$ foi operado por 49 dias.

Os lisímetros R9 e R10 foram operados sob as condições do ponto central do planejamento fatorial, ou seja, foram operados como replicatas. A operação destes lisímetros ocorreu em temperatura de incubação de $45^{\circ} \mathrm{C}$, alimentados com $750 \mathrm{~g}$ de papel com teor de umidade de $66 \%$ em R9 e $67 \%$ em R10 por um período de 49 dias. O papel adicionado como substrato nos lisímetros R9 e R10 foi umidificado e inoculado pelo mesmo afluente, cujos parâmetros físico-químicos estão descritos na Tabela 5.3.

Tabela 5.3 - Caracterização do afluente para umidificação e inoculação do Papel nos Lisímetros R1 a R10

\begin{tabular}{|c|c|c|c|c|}
\hline Parâmetros & R1, R2 e R3 & R4 & R5, R6 e R7 & R8, R9, R10 \\
\hline $\begin{array}{l}\text { Carboidratos - } \\
\text { Totais solúveis } \\
(\mathrm{mg} / \mathrm{L})\end{array}$ & $\begin{array}{c}2,83 \\
( \pm 0,01)\end{array}$ & < L.D. & $\begin{array}{c}10,84 \\
( \pm 4,03)\end{array}$ & <L.D. \\
\hline $\begin{array}{l}\text { Carboidratos - } \\
\text { Totais }(\mathrm{mg} / \mathrm{L})\end{array}$ & $\begin{array}{c}194,72 \\
( \pm 63,74)\end{array}$ & $\begin{array}{c}905 \\
( \pm 261,63)\end{array}$ & $\begin{array}{c}154,45 \\
( \pm 26,53)\end{array}$ & $\begin{array}{c}364.6 \\
( \pm 13,6)\end{array}$ \\
\hline $\begin{array}{c}\text { DQO - Total } \\
(\mathrm{mg} / \mathrm{L})\end{array}$ & $\begin{array}{c}9,60 \\
( \pm 1,49)\end{array}$ & $\begin{array}{c}39,60 \\
( \pm 2,04)\end{array}$ & $\begin{array}{c}6,98 \\
( \pm 5,18)\end{array}$ & $\begin{array}{c}35,09 \\
( \pm 4,23)\end{array}$ \\
\hline $\begin{array}{c}\text { DQO - Total } \\
\text { solúvel (mg/L) }\end{array}$ & $\begin{array}{l}405,02 \\
( \pm 8,92)\end{array}$ & $\begin{array}{c}1.238 \\
( \pm 104,65)\end{array}$ & $\begin{array}{c}232,5 \\
( \pm 21,49)\end{array}$ & $\begin{array}{r}292,44 \\
( \pm 1,73)\end{array}$ \\
\hline $\mathrm{pH}$ inicial & 5,5 & 5,5 & 5,5 & 5,5 \\
\hline $\operatorname{STV}(\mathrm{g} / \mathrm{L})$ & $\begin{array}{c}1,1 \\
( \pm 0,28)\end{array}$ & $\begin{array}{r}1,3 \\
( \pm 0,31)\end{array}$ & $\begin{array}{c}1,1 \\
( \pm 0,28)\end{array}$ & $\begin{array}{c}0,6 \\
( \pm 0,3)\end{array}$ \\
\hline
\end{tabular}


Após a umidificação/ inoculação do papel e o preenchimento dos lisímetros para a o início da operação, os parâmetros analisados estão listados na Tabela 5.3.

Tabela 5.4 - Parâmetros ao Início da operação dos lisímetros de R1 a R10

\begin{tabular}{|c|c|c|c|c|c|c|}
\hline Lisímetro & $\begin{array}{c}\text { Papel } \\
(\mathrm{g})\end{array}$ & $\begin{array}{c}\text { Teor de } \\
\text { Umidade } \\
(\%)\end{array}$ & $\begin{array}{c}\text { Papel } \\
\text { Inoculado } \\
\text { (g) }\end{array}$ & $\begin{array}{l}\text { Altura } \\
\text { Leito } \\
\text { Papel } \\
(\mathrm{cm})\end{array}$ & $\begin{array}{c}\text { Altura } \\
\text { headspace } \\
(\mathrm{cm})\end{array}$ & $\begin{array}{c}\mathrm{T} \\
\left({ }^{\circ} \mathrm{C}\right)\end{array}$ \\
\hline $\mathrm{R} 1$ & 1000 & 78 & $2.076,46$ & 30 & 20 & 35 \\
\hline $\mathrm{R} 2$ & 500 & 85 & $1.088,33$ & 16 & 34 & 35 \\
\hline R3 & 500 & 48 & 733,96 & 20,5 & 31 & 35 \\
\hline R4 & 1000 & 47 & $1.484,75$ & 32 & 18 & 35 \\
\hline R5 & 1000 & 81 & $2.101,30$ & 28 & 25 & 55 \\
\hline R6 & 500 & 82 & $1.048,38$ & 17 & 36 & 55 \\
\hline R7 & 500 & 55 & 738,68 & 21 & 33 & 55 \\
\hline $\mathrm{R} 8$ & 1000 & 56 & 1.498 & 33 & 17 & 55 \\
\hline R9 & 750 & 66 & 1.302 & 26 & 27 & 45 \\
\hline R10 & 750 & 67 & 1.305 & 26 & 27 & 45 \\
\hline
\end{tabular}

Ao longo do período de operação foi monitorada a produção de gas hidrogênio, gás carbônico, nitrogênio e metano no headspace dos lisímetros. A liberação de percolado nos lisímetros ocorreu após o substrato estar totalmente saturado de umidade, ou seja, após alguns dias de operação e, a partir desse período, foram monitorados, além de biogás, a composição de ácidos orgânicos voláteis e álcoois, DQO, carboidratos totais e solúveis, série de sólidos totais, $\mathrm{pH}$ e série de alcalinidade. Uma vez que as condições tiveram teores de umidade iniciais do papel (substrato) variadas, esse tempo para formação do percolado também variou durante as operações de R1 a R10. 
A produção de hidrogênio foi observada nas condições R1, R2 e R5, nas quais o teor de umidade incial do papel foi de $80 \%$. A produção foi maior nos lisímetros operados em temperatura mesofílica (R1 e R2), e foi muito reduzida na condição termofílica R5, na qual foi observado favorecimento da produção de metanol e etanol. Nas três condições, produção de hidrogênio detectável foi observada nos dias iniciais de operação, com pico entre aproximadamente 25 e $35 \mathrm{mmol}$ em R1 e R2 e 3 mmol em R5 (Figura 5. 7), porém, a quantidade de hidrogênio decresceu gradativamente para valores abaixo do limite de detecção do método até não ser mais detectado no headspace (Figura 5.7). Assim como observado nas Etapas Preliminares de operação I e II, não houve segundo pico de produção de hidrogênio durante o restante do período de operação em nenhuma das três condições.

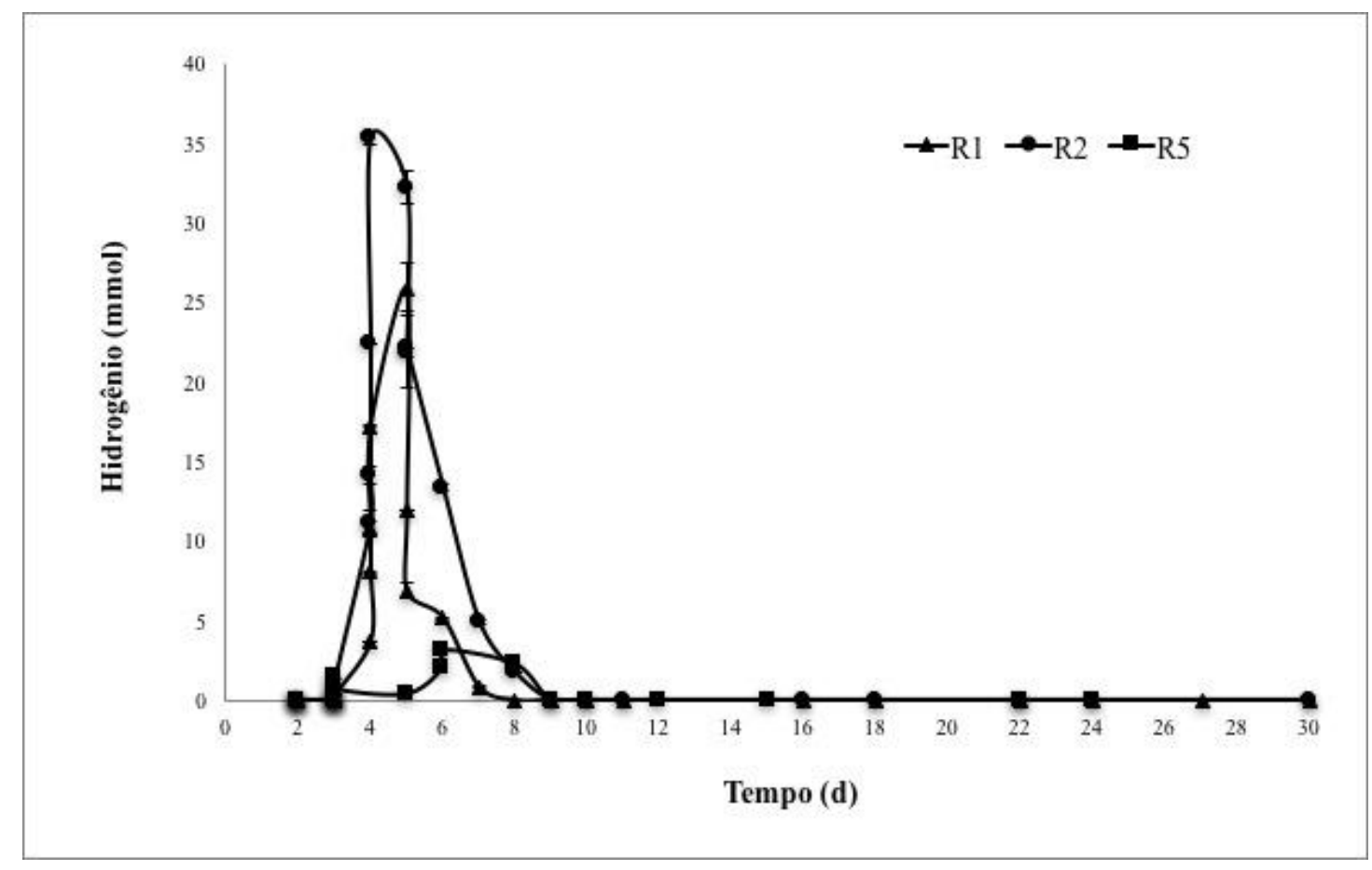

Figura 5.7 - Número de mol de Hidrogênio nas condições R1 (1000 g; 80\%; $\left.35^{\circ} \mathrm{C}\right)$, R2 (500 g; $\left.80 \% ; 35^{\circ} \mathrm{C}\right)$ e R5 (1000 g; 80\%; 55 $\left.\mathrm{C}\right)$

Ajustando-se os dados de produção de hidrogênio em R1 e R2 ao modelo de Gompertz modificado, foram calculados o potencial máximo de produção de hidrogênio $(P)$, a velocidade máxima de produção de hidrogênio $(R m)$ e o período necessário para início da produção de hidrogênio detectável $(\lambda)$ (Tabela 5.5). 
Tabela 5.5 - Parâmetros obtidos pelo ajuste da produção de hidrogênio no modelo de Gompertz modificado

\begin{tabular}{ccccc}
\hline Condição & $P(\mathrm{mmol})$ & $R m(\mathrm{mmol} / \mathrm{dia})$ & $\lambda$ (dia) & $\mathrm{R}^{2}$ \\
\hline $\mathrm{R} 1$ & 30,71 & 1,02 & 2,35 & 0,998 \\
$\mathrm{R} 2$ & 34,73 & 2,26 & 2,33 & 0,990 \\
\hline
\end{tabular}

Esses dados foram semelhantes àqueles obtidos na Etapa II. Segundo o ajuste, obteve-se para as condições do R2 $\left(500 \mathrm{~g} ; 80 \%\right.$; 35 $\left.{ }^{\circ} \mathrm{C}\right)$ produção de hidrogênio superior ao da Etapa I (1000 g; 80\%; $\left.25^{\circ} \mathrm{C} ; \mathrm{pH} 7,0\right)$ e similar ao da Etapa II $\left(1000 \mathrm{~g} ; 80 \% ; 25^{\circ} \mathrm{C}\right.$; $\mathrm{pH}$ 6,5), com aumento apenas da velocidade máxima de produção de 1,7 para 2,26 mmol/dia, respectivamente. A partir desses resultados, verificou-se maior velocidade máxima e potencial máximo de produção de hidrogênio em R2, quando comparado a R1 $\left(1000 \mathrm{~g} ; 80 \% ; 35^{\circ} \mathrm{C}\right)$, sendo que a única diferença entre ambos foi a massa de papel adicionada, que foi a metade em R2 (500g).

As condições operacionais aplicadas em R1e R2 operados a $35^{\circ} \mathrm{C}$, temperatura próxima àquela aplicada nas etapas preliminares $\left(25^{\circ} \mathrm{C}\right)$, e em R5 $\left(1000 \mathrm{~g} ; 80 \%\right.$; $\left.55^{\circ} \mathrm{C}\right)$ este já operado sob temperatura termofílica, não foram satisfatórias para aumentar a produção de hidrogênio, ou ao menos estabilizar sua quantidade no headspace por período mais prolongado, já que houve redução do mesmo logo no início da operação (Figura 5.8). Em todas condições aplicadas nos lisímetros (R1 a R10), não houve produção de metano detectável pelo método cromatográfico. Houve, portanto, provável consumo deste gás por metabolismos como homoacetogênese, acetogênese e produção de compostos reduzidos (DRAKE, DANIEL, 2014; SAADY, 2013), já que não foram detectados metano e sulfeto de hidrogênio nos lisímetros.

Ao longo do período de operação dos lisímetros, pôde-se acompanhar a produção concomitante de ácidos orgânicos voláteis e solventes detectados no percolado, e, por meio de uma análise geral da composição destes metabólitos entre as condições estudadas, observou-se produção de compostos considerados vetores energéticos em potencial. Dentre eles, destacaram-se o ácido acético, etanol e metanol.

Nos lisímetros R1 e R2, concentrações muito elevadas de ácido acético, seguido de produção expressiva de ácido butírico e etanol foram observadas. Em R3 (500 g; 50\%; $\left.35^{\circ} \mathrm{C}\right)$ e R7 $\left(1000 \mathrm{~g} ; 50 \% ; 35^{\circ} \mathrm{C}\right)$ não foi possível realizar tais análises pela ausência de percolado produzido no lisímetro. Pôde-se observar ocorrência mais acentuada de álcoois 
nos percolados dos lisímetros termofílicos, com destaque para R5 (1000 g; 80\%; 55 $\left.{ }^{\circ} \mathrm{C}\right)$, visto que em R6 $\left(500 \mathrm{~g} ; 80 \% ; 55^{\circ} \mathrm{C}\right)$ a produção de hidrogênio não foi detectada e a de metabólitos foi muito reduzida.

Nos lisímetros alimentados com papel em teor de umidade de 50\% (R4 e R8), não foi observada produção de hidrogênio detectável no headspace, e além disso, as concentrações de metabólitos solúveis foram muito reduzidas, ou seja, houve atividade microbiana atenuada nesta condição de processo, tanto a $35^{\circ} \mathrm{C}$ quanto a $55^{\circ} \mathrm{C}$. Para os pontos centrais R9 $\left(750 \mathrm{~g} ; 65 \% ; 45^{\circ} \mathrm{C}\right)$ e R10 $\left(750 \mathrm{~g} ; 65 \% ; 45^{\circ} \mathrm{C}\right)$, verificou-se variação reduzida quanto aos resultados analisados, indicando repetibilidade do experimento.

Em R1 (1000 g; 80\%; 35 $\left.{ }^{\circ} \mathrm{C}\right)$, ao longo de toda a operação verificou-se prevalência de ácido acético e ácido butírico no percolado (Figura 5.8A-C). No $5^{\circ}$ dia de operação, em que foi observado o pico de produção de hidrogênio no headspace, foram detectadas concentrações de aproximadamente 7.100 e $3.800 \mathrm{mg} / \mathrm{L}$ de ácidos acético e butírico, respectivamente (Figura 5.8A). A partir desse período, verficou-se manutenção estável da concentração de ácido butírico ao longo do período de operação, tornando-se reduzida apenas nos últimos dias (Figura 5.8A). Em contrapartida, foi observado aumento expressivo da concentração de ácido acético, no oitavo dia de operação, alcançando, aproximadamente, $21.500 \mathrm{mg} / \mathrm{L}$ (Figura 5.8A). Foi observado que a concentração de ácido acético se manteve elevada ao longo de quase todo o período de operação, com redução apenas nos dias finais. Outros ácidos, tais como propiônico, isobutírico, isovalérico, valérico e capróico também foram detectados no percolado, porém em concentrações menos expressivas (Figura 5.8B). Em relação aos álcoois, foi observada produção de n-butanol e, principalmente, etanol nos primeiros dias de operação, com concentrações máximas detectadas de aproximadamente 228 e 1.570 mg/L, respectivamente. 


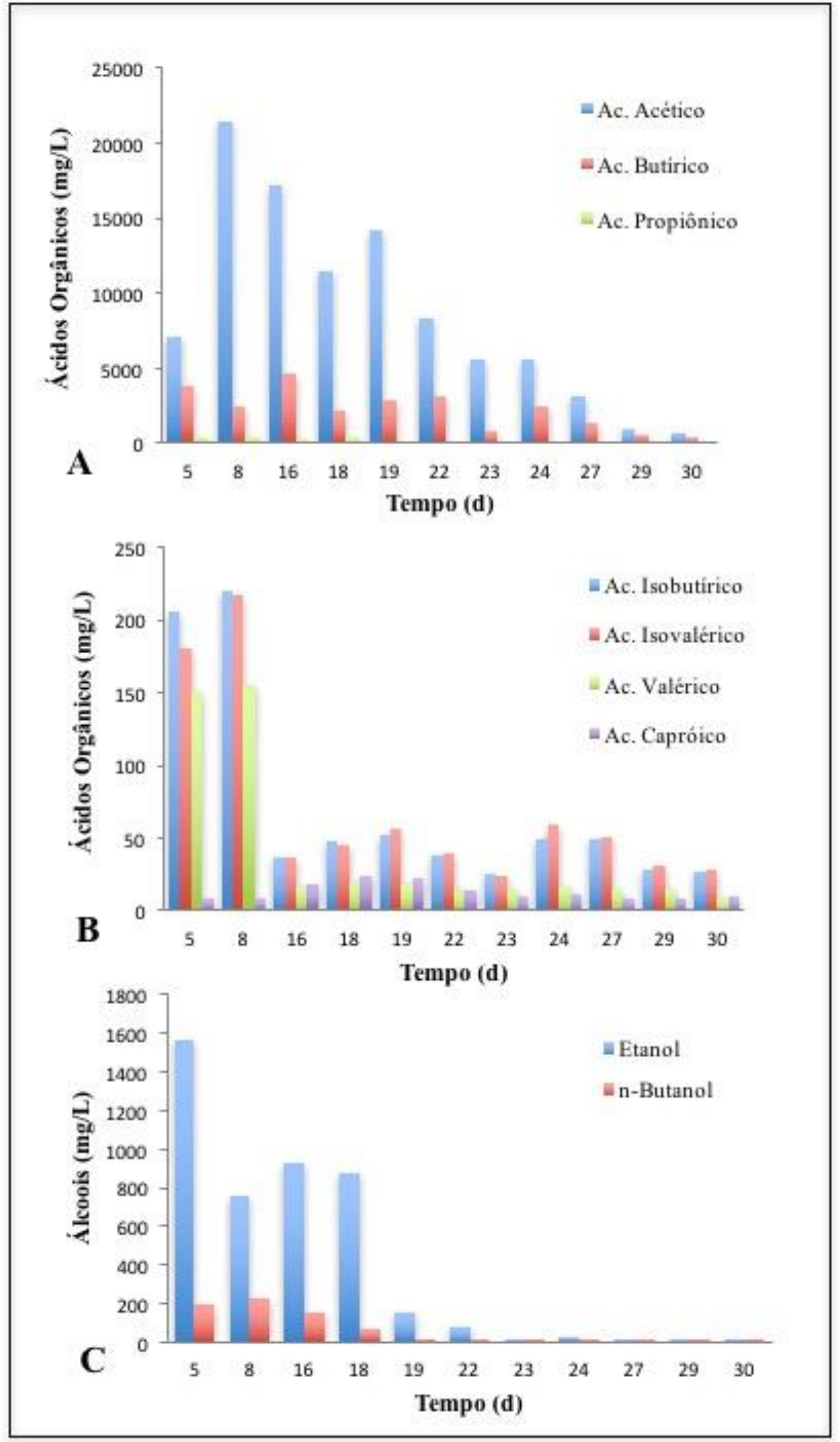

Figura 5.8 - Compostos orgânicos solúveis no percolado do R1 (1000 g; $80 \% ; 3^{\circ} \mathrm{C}$ ). (A) Ácidos orgânicos: acético, butírico e propiônico; (B) Ácidos orgânicos: isobutírico, isovalérico, valérico e caproico; (C) Álcoois: etanol e n-butanol 
Ao longo de toda a operação de R2 $\left(500 \mathrm{~g} ; 80 \% ; 35^{\circ} \mathrm{C}\right)$, assim como em R1 (1000 $\mathrm{g} ; 80 \% ; 35^{\circ} \mathrm{C}$ ), verificou-se concentrações pronunciadas de ácido acético e ácido butírico e etanol (Figura 5.9 A,C). No $5^{\circ}$ dia de operação foram detectados 7.500 e $2.800 \mathrm{mg} / \mathrm{L}$ de ácido acético e ácido butírico no percolado (Figura 5.9A), além de concentração expressiva de etanol ( 1.800 mg/L) (Figura 5.9C).

Os três compostos estão diretamente relacionados com o metabolismo fermentativo de bactérias do rúmen, como descrito para aquelas semelhantes à Ruminococcus e Clostridium, por exemplo (BOTTA, 2012; FLINT et al., 2008; NTAIKOU; KOUTOS, KORNAROS, 2009). De acordo com os resultados relatados acima, em R1 e R2, o hidrogênio foi produzido, provavelmente, pela via do ácido acético, com menor contribuição pela via do ácido butírico.

Bactérias semelhantes a Ruminococcus são conhecidamente fermentadoras de celulose e produtoras de hidrogênio, gás carbônico, ácidos acético e fórmico, e etanol (NTAIKOU et al., 2008). A produção de etanol observada no início da operação também foi observada nas etapas preliminares de operação dos lisímetros, e deve estar relacionada com a hidrólise e fermentação de papel por ruminococos presentes no fluido de rúmen. Assim como nas etapas preliminares, houve diminuição da concentração de etanol e nbutanol até valores abaixo do limite de detecção, ao longo do período de operação que também pode estar relacionado à produção de ácido acético, por acetogênese (DIEKERT; WOHLFARTH, 1994).

$\mathrm{Na}$ condição R2 $\left(500 \mathrm{~g} ; 80 \% ; 35^{\circ} \mathrm{C}\right)$, a quantidade de hidrogênio também decresceu gradativamente no headspace seguido de aumento expressivo da concentração de ácido acético no percolado, de $7.500 \mathrm{mg} / \mathrm{L}$ no $5^{\circ}$ dia para $14.000 \mathrm{mg} / \mathrm{L}$ no $8^{\circ}$ dia de operação, atingindo concentração máxima de $\sim 17.000 \mathrm{mg} / \mathrm{L}$ no $21^{\circ}$ dia de operação (Figura 5.9A). Já para o ácido butírico e etanol, verificou-se concentrações reduzidas no percolado ao longo do período analisado (Figura 5.9A,C).

O aumento da concentração de ácido acético no percolado não foi acompanhada por aumento da concentração de hidrogênio no headspace, tanto em R1, quanto em R2, e provavelmente se deveu aos metabolimos de homoacetogênese e acetogênese, sendo que o primeiro envolve o consumo de hidrogênio e gás carbônico para produção de ácido acético (SAADY, 2013).

A concentração dos outros ácidos orgânicos analisados aumentou no mesmo período em que houve diminuição da quantidade de hidrogênio no headspace. Diferentemente de R1, a concentração de ácido propiônico foi crescente ao longo da 
operação em R2, com concentração máxima detectada de $800 \mathrm{mg} / \mathrm{L}$ no $21^{\circ}$ dia de operação (Figura 5.9A). Além do propiônico, verificou-se para os ácidos isobutírico, isovalérico, valérico e capróico maiores concentrações entre o $15^{\circ}$ e $17^{\circ}$ dia de operação, quando já não havia mais hidrogênio no headspace, entretanto as concentrações reduziram até o final da operação (Figura 5.9B).

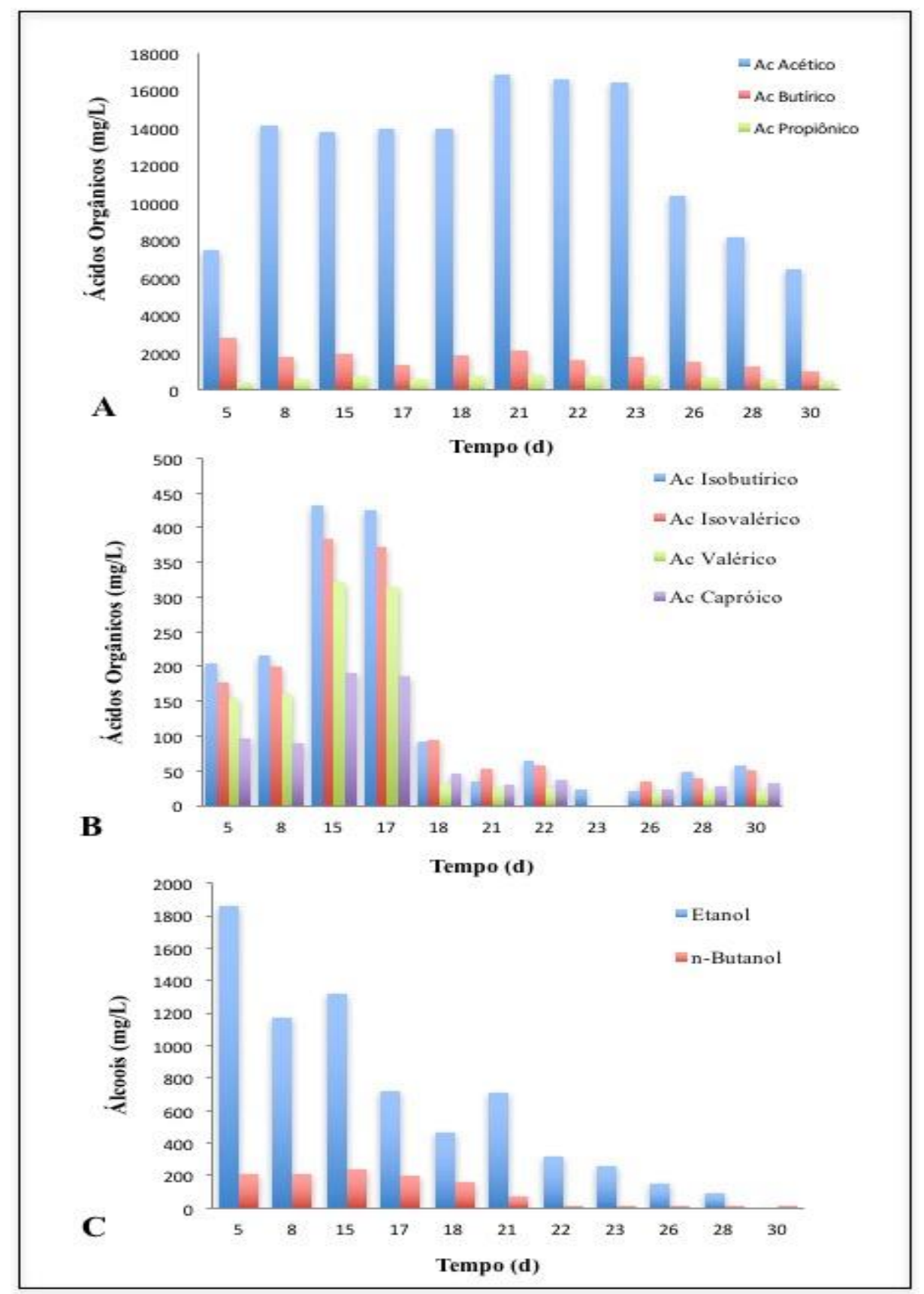

Figura 5.9 - Compostos orgânicos solúveis no percolado do R2 (500 g; $80 \% ; 35^{\circ} \mathrm{C}$ ). (A) Ácidos orgânicos: acético, butírico e propiônico; (B)

Ácidos orgânicos: isobutírico, isovalérico, valérico e caproico; (C) Álcoois: etanol e n-butanol 
Durante a operação de R4 (1000 g; 50\%; 35² C), metabólitos solúveis como ácidos orgânicos e álcoois foram produzidos em concentrações muito reduzidas se comparadas a R1 $\left(1000 \mathrm{~g} ; 80 \% ; 35^{\circ} \mathrm{C}\right)$ e R2 $\left(500 \mathrm{~g} ; 80 \% ; 35^{\circ} \mathrm{C}\right)$. Diferentemente de R1 e R2, ácido butírico foi o metabólito prevalente, com concentração máxima de aproximadamente $1.150 \mathrm{mg} / \mathrm{L}$, ao passo que o ácido acético foi detectado em apenas $150 \mathrm{mg} / \mathrm{L}$ (Figura 5.10A). A produção desses ácidos é geralmente acompanhada da produção de $\mathrm{H}_{2}$, entretanto este gás não foi detectado no headspace. $\mathrm{O}$ etanol também prevalesceu e atingiu concentração de aproximadamente $400 \mathrm{mg} / \mathrm{L}$ (Figura 5.10C). Esses dados estão em conformidade com aqueles obtidos para R1 e R2, também operados a $35^{\circ} \mathrm{C}$, quando verficou-se produção expressiva de etanol. Concentrações reduzidas de metanol e dos ácidos isobutírico, isovalérico, valérico e caproico foram detectadas com concentrações máximas de $50 \mathrm{mg} / \mathrm{L}$ no percolado de R4 (1000 g; 50\%; 35 $\left.{ }^{\circ} \mathrm{C}\right)$ (Figura 5.10B, C). 


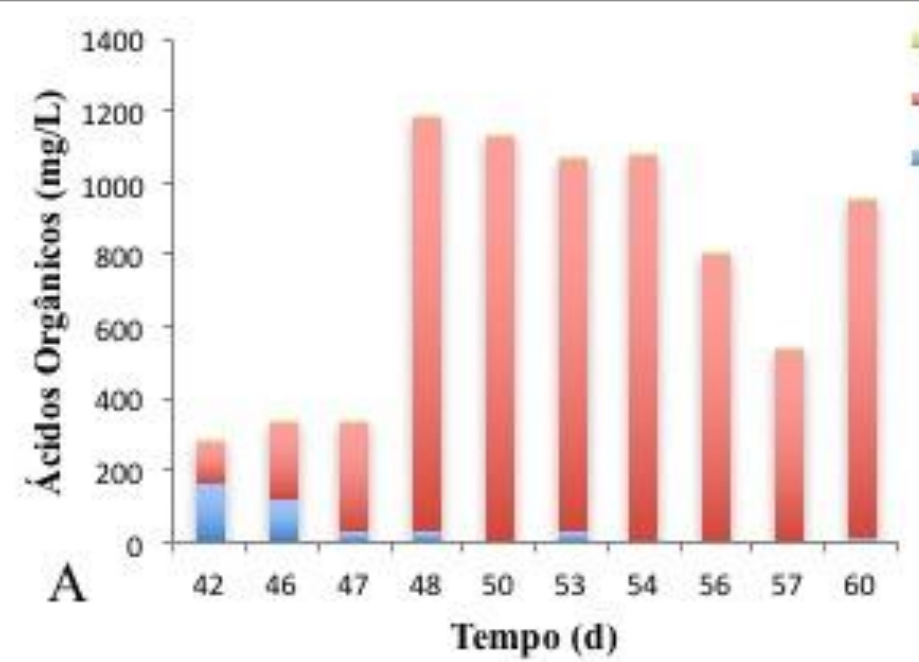

Ac. Propiónico

Ac. Butirico

Ac. Acćtico

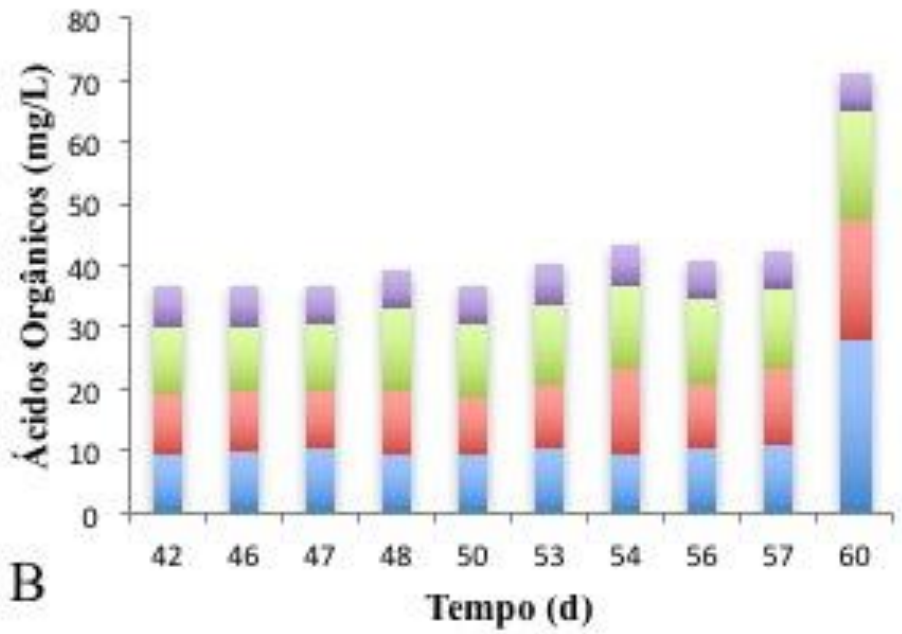

ac. Capróico

Ac. Valèrico

= Ac. Isovalérico

Ac. Isobutirico

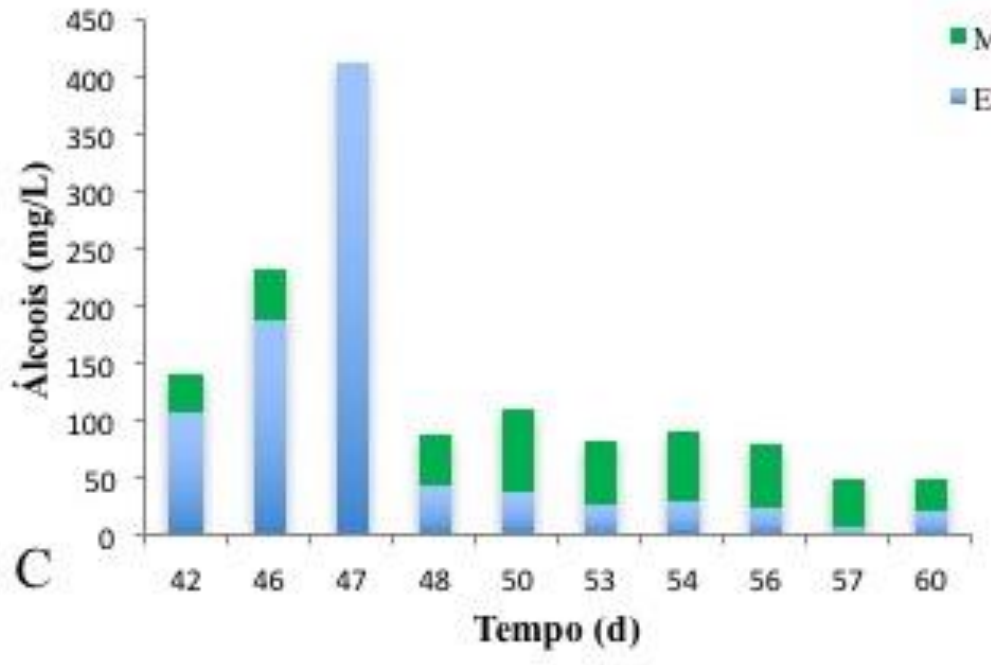

Figura 5.10 - Compostos orgânicos solúveis no percolado de R4 (500 g; $50 \% ; 3^{\circ} \mathrm{C}$ ). (A) Ácidos orgânicos: acético, butírico e propiônico; (B) Ácidos orgânicos: isobutírico, isovalérico, valérico e caproico; (C) Álcoois: etanol e metanol 
Em R5 (1000 g; 80\%; 55ㄷ), pôde-se observar que, semelhante às operações mesofílicas, foram detectadas concentrações expressivas de ácido acético e ácido butírico no percolado, com valores máximos de $\sim 10.000$ e $4.000 \mathrm{mg} / \mathrm{L}$, respectivamente (Figura 5.11A). As elevadas concentrações de ácido acético, não acompanhada pelo aumento da produção de hidrogênio, permitem inferir a ocorrência de homoacetogênese na operação $\mathrm{R} 5$, ainda que em temperatura termofílica e $\mathrm{pH}$ inicial de 5,5. Dessa forma, esses resultados são contrários aos relatos de Luo et al. (2011) que reportaram inibição de homoacetogênese nessas mesmas condições operacionais, mesmo após longo prazo de cultivo do inóculo pré-tratado. Como citado anteriormente, o etanol também pode ter sido utilizado como substrato para produção de ácido acético por bactérias acetogênicas (SAADY, 2013).

A homoacetogênese foi identificada em diversos estudos sobre produção de hidrogênio a partir de diferentes substratos e em configurações de reatores diversas, mas as formas de inibí-la ou evitá-la ainda não estão definidas, sendo considerado um desafio nesta área (SAADY, 2013). Lima, Moreira e Zaiat (2013) e Penteado et al. (2013) relataram a diminuição de hidrogênio devido à homoacetogênese em reatores mesofílicos com leito empacotado, usando substrato sintético à base de sacarose. Braga (2014) também observou a ocorrência de homoacetogênese em reator tubular com leito empacotado sob operação termofílica $55{ }^{\circ} \mathrm{C}$ com TDH de $0,5 \mathrm{~h}$, ao passo que não foi verificada no TDH de 2 horas. A autora propôs a hipótese de que a homoacetogênese foi resultado da alta da carga orgânica volumétrica sob TDH de 0,5 hora, o que levou à diminuição da relação substrato/micro-organismo, de forma que as bactérias alteraram o seu metabolismo para crescimento autotrófico. Nos três estudos citados acima, os processos não foram estáveis e os rendimentos de hidrogênio decresceram até próximos a zero ao longo da operação.

Além destes ácidos, verificou-se também concentrações de metanol, que atingiu valor próximo a $5.600 \mathrm{mg} / \mathrm{L}$ e etanol, este último com comportamento semelhante ao observado nas operações mesofílicas, ou seja, foi detectado em concentrações relevantes no início da operação $(\sim 2.300 \mathrm{mg} / \mathrm{L})$, mas foi reduzindo gradativamente até não ser detectável ao final da operação (Figura 5.11C). Apesar do comportamento similar, a produção de etanol foi mais acentuada na operação termofílica, já que no $10^{\circ}$ dia de operação de R5, foi detectado $2.300 \mathrm{mg} / \mathrm{L}$ deste composto (Figura 5.11C), enquanto, para $\mathrm{R} 1\left(1000 \mathrm{~g} ; 80 \% ; 35^{\circ} \mathrm{C}\right)$ e R2 $\left(500 \mathrm{~g} ; 80 \% ; 35^{\circ} \mathrm{C}\right)$, as concentrações máximas de etanol detectadas foram de 1.800 e $1.500 \mathrm{mg} / \mathrm{L}$, respectivamente (Figuras 5.8C; 5.9C). As 
concentrações de etanol podem ter atingido valores ainda maiores no início da operação de R5 (1000 g; 80\%; 55 $\mathrm{C})$, período em que ainda não havia formação de percolado no lisímetro, e, portanto, não foram quantificadas. Ademais, como observado em R1 e R2, o etanol foi provavelmente consumido e convertido a outros compostos orgânicos durante o período de operação.

A produção de outros compostos orgânicos também foi observada ao longo da operação termofílica, tal como de ácido propiônico, este último detectado em concentração muito expressiva com máxima de $4.500 \mathrm{mg} / \mathrm{L}$ (Figura 5.11A,B). 


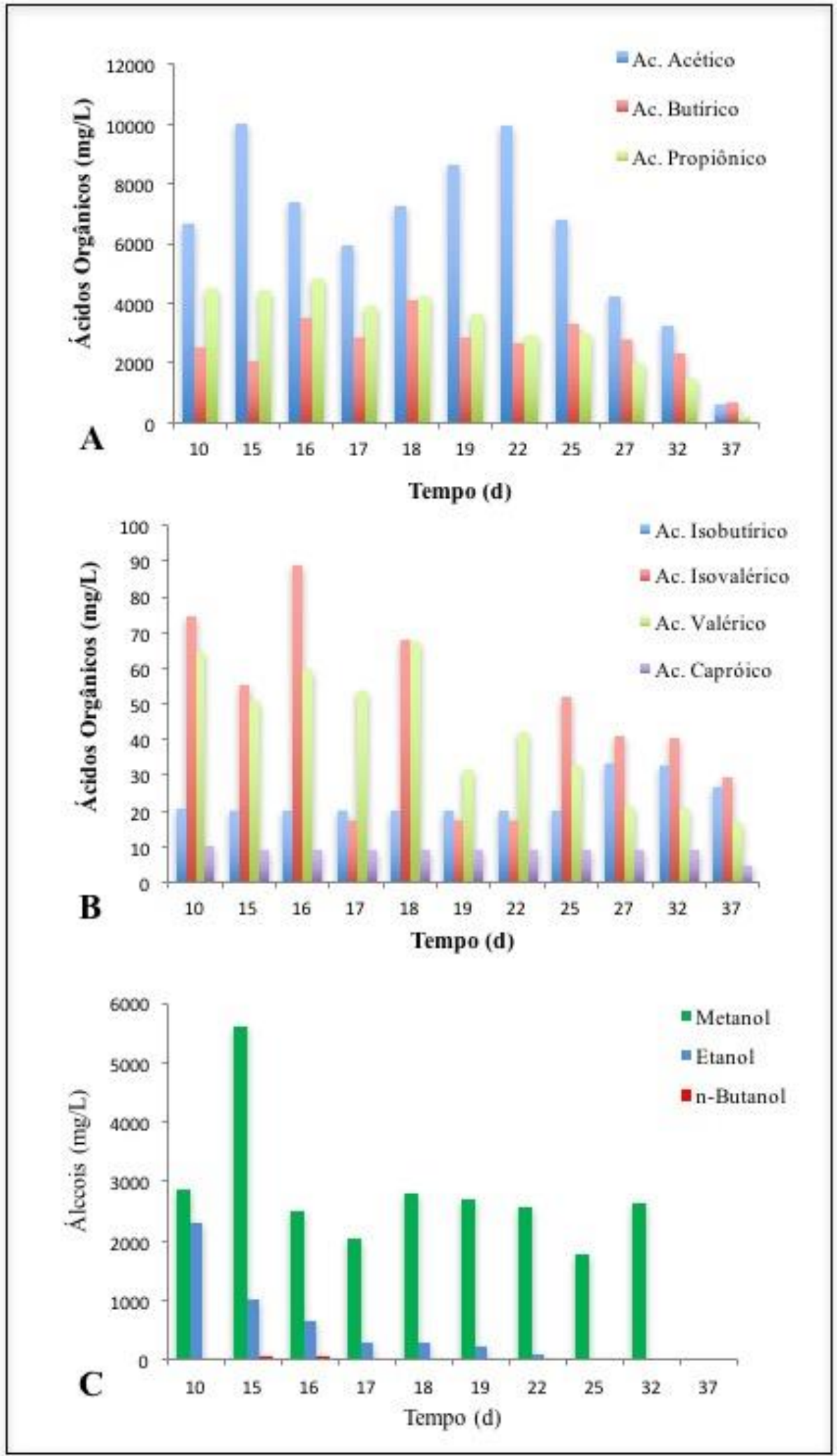

Figura 5.11 - Compostos orgânicos solúveis no percolado de R5 (1000 g; 80\%; 55ㄷ). (A) Ácidos orgânicos: acético, butírico e propiônico; (B) Ácidos orgânicos: isobutírico, isovalérico, valérico e caproico; (C) Álcoois: etanol, metanol e n-butanol 
Em R6 $\left(500 \mathrm{~g} ; 80 \% ; 55^{\circ} \mathrm{C}\right)$ semelhante à R5 $\left(1000 \mathrm{~g} ; 80 \% ; 55^{\circ} \mathrm{C}\right)$ observou-se produção de metanol, que nesse caso, foi o principal composto detectado ao longo da operação (Figura 5.12). A concentração máxima de metanol detectada foi de, aproximadamente, $1.094 \mathrm{mg} / \mathrm{L}$ no $15^{\circ}$ dia de operação (Figura 5.12C). O ácido acético, principal composto orgânico produzido nos outros lisímetros, foi detectado em baixa concentração no $15^{\circ}$ dia de operação, porém aumentou ao longo do período de operação, atingindo concentração máxima de aproximadamente $780 \mathrm{mg} / \mathrm{L}$ no $23^{\circ}$ dia (Figura 5.12A). Apesar da produção deste ácido, não foi detectado hidrogênio no headspace do lisímetro.

Populações fermentativas acidogênicas, não produtoras de hidrogênio, são comuns na microbiota do rúmen e, portanto, nas condições estudadas a produção de ácidos orgânicos pode não ter sido acompanhada de geração de hidrogênio (FLINT et al., 2008). Além disso, a geração de ácido acético pode estar relacionada a metabolismos de acetogênese, já que foi acompanhada pela diminuição da concentração de metanol, por exemplo (YAMAMURO et al., 2014). Para os outros ácidos, tais como propiônico, butírico, isobutírico e isovalérico também verificou-se concentrações crescentes ao longo da operação, porém reduzidas (Figura 5.12A,B). Quanto ao etanol, a partir do período de operação analisado, não houve detecção de concentração expressiva, ao contrário do observado nas operações anteriores (Figura 5.12C). 


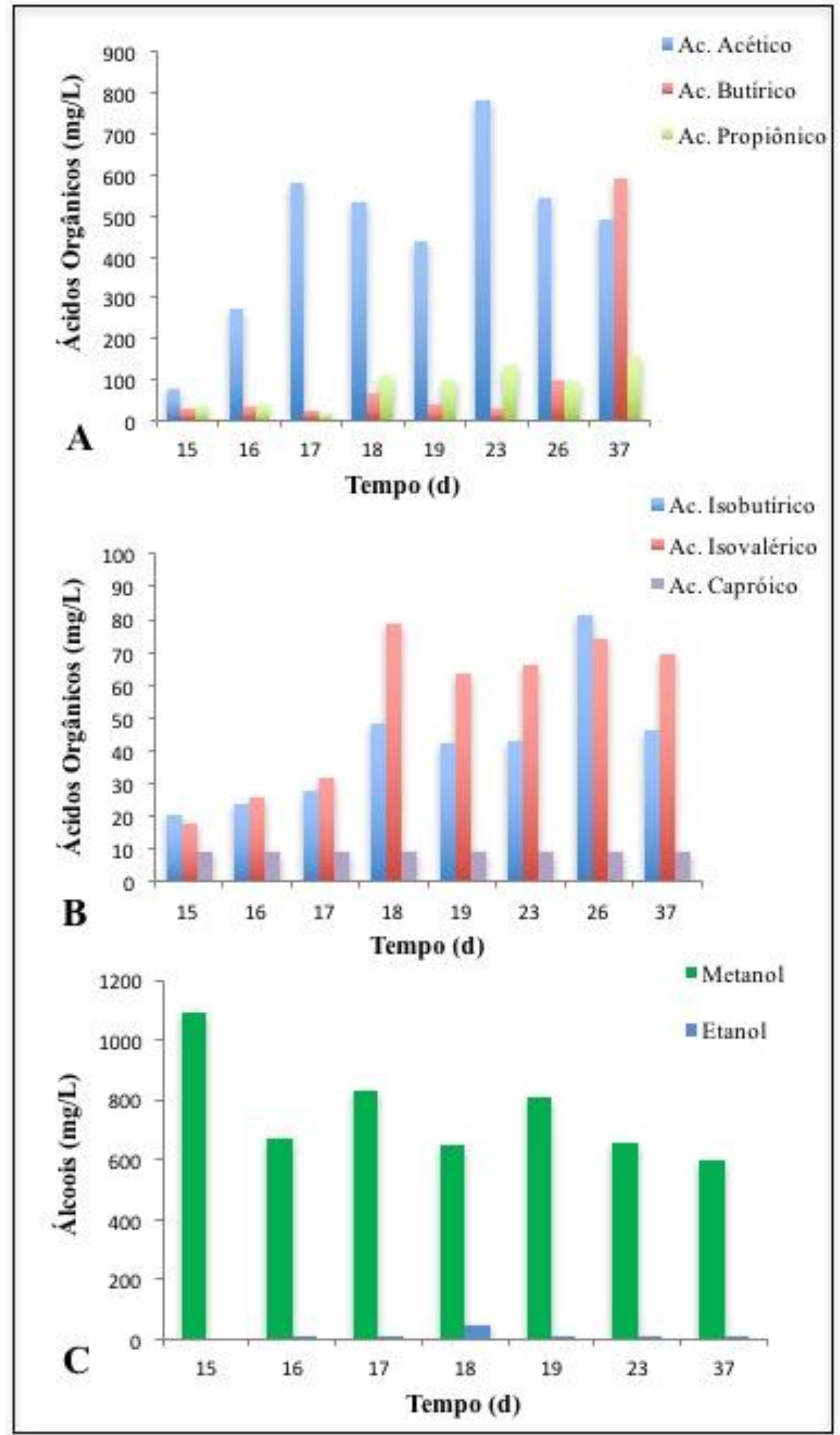

Figura 5.12 - Compostos orgânicos solúveis no percolado do R6 (500 g; $80 \% ; 5^{\circ} \mathrm{C}$ ). (A) Ácidos orgânicos: acético, butírico e propiônico; (B) Ácidos orgânicos: isobutírico, isovalérico, valérico e caproico; (C) Álcoois: etanol e metanol 
No percolado de $\mathrm{R} 8\left(1000 \mathrm{~g} ; 50 \% ; 55^{\circ} \mathrm{C}\right)$, verificou-se prevalência de ácido acético, seguido de metanol e ácido butírico no efluente, porém em concentrações muito reduzidas comparado às outras condições relatadas. Concentrações máximas de aproximadamente 450, 95 e $90 \mathrm{mg} / \mathrm{L}$ foram detectadas para estes compostos respectivamente (Figura 5.13A-C). Os compostos observados estão de acordo com aqueles observados nos lisímetros R5 (1000 g; 80\%; 55 $\mathrm{C})$ e R6 $\left(500 \mathrm{~g} ; 80 \% ; 55^{\circ} \mathrm{C}\right)$, também operados a $55^{\circ} \mathrm{C}$. Nestes lisímetros, a produção de hidrogênio foi reduzida ou ausente e pôde-se observar a prevalência de fermentação alcóolica, formando principalmente etanol e metanol no percolado.

Em R8, também foi observada a ocorrência de metanol no percolado durante o período analisado (Figura 5.13C), reforçando a produção deste composto nesta temperatura $\left(55^{\circ} \mathrm{C}\right)$ por parte da microbiota usada como inóculo (fluido de rúmen enriquecido). Outros compostos orgânicos como etanol, ácido propiônico, e os ácidos isobutírico, isovalérico, valérico e capróico foram detectados em concentrações que não excederam $50 \mathrm{mg} / \mathrm{L}$ ao longo do período analisado (Figura 5.13A-C). Pela análise dos metabólitos solúveis detectados no percolado dos lisímetros R5, R6 e R8 pode-se inferir que a temperatura termofílica favoreceu à fermentação de papel voltada à geração de álcoois. 


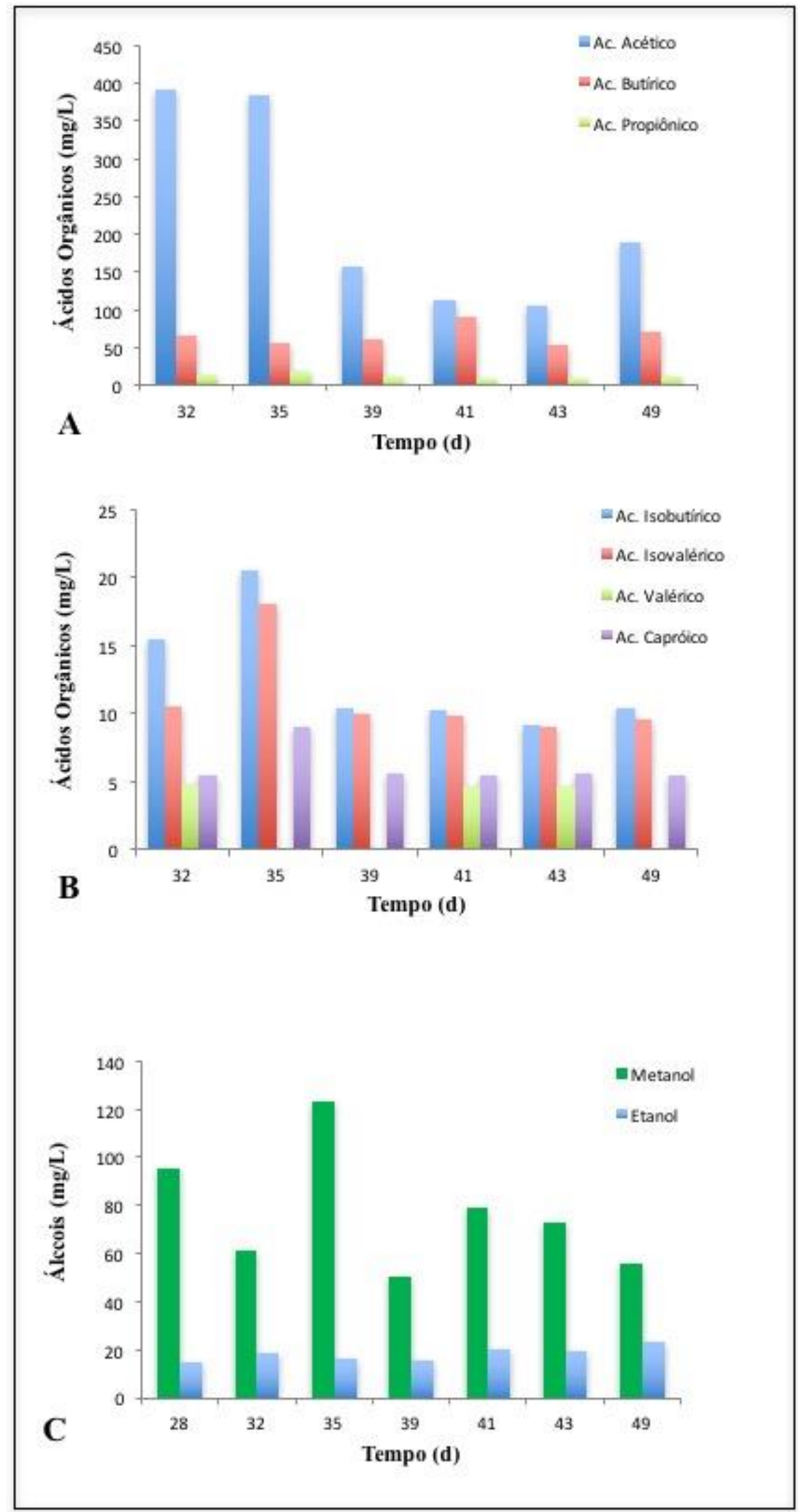

Figura 5.13 - Compostos orgânicos solúveis no percolado do R8 $\left(1000 \mathrm{~g} ; 50 \% ; 5^{\circ} \mathrm{C}\right)$. (A) Ácidos orgânicos: acético, butírico e propiônico; (B) Ácidos orgânicos: isobutírico, isovalérico, valérico e caproico; (C) Álcoois: etanol e metanol 
Braga (2014) relatou concentração expressiva de metanol no efluente de reatores de produção de hidrogênio a partir de substrato sintético à base de sacarose, sob temperatura termofílica de $55{ }^{\circ} \mathrm{C}$. No reator UASB, com TDH de 12 horas, os maiores valores de rendimento de hidrogênio ( 3 moles $\mathrm{H}_{2} / \mathrm{mol}$ sacarose) ocorreram quando as concentrações de etanol e metanol representavam 50\% dos metabólitos totais. Além disso, no reator tubular de leito empacotado com TDH de 2 horas, a solventogênese foi a rota principal, com etanol representando $60 \%$ dos metabólitos totais. Metanol também foi produzido de forma expressiva no reator tubular sem material suporte, em TDH de $0,5 \mathrm{~h}$, com aproximadamente, 4,62 mmol/L, sendo o metabólito majoritário (44\%) detectado no efluente deste reator. Esses resultados estão em conformidade com os obtidos neste estudo na operação dos lisímetros em temperatura termofílica, nos quais o metanol foi um dos principais metabólitos solúveis detectados no efluente de R5 (1000 g; 80\%; 55 $\left.{ }^{\circ} \mathrm{C}\right)$,

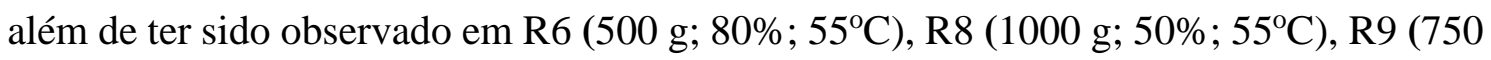
$\left.\mathrm{g} ; 50 \% ; 45^{\circ} \mathrm{C}\right)$ e R10 $\left(750 \mathrm{~g} ; 50 \% ; 45^{\circ} \mathrm{C}\right)$ em concentrações mais reduzidas.

Ao longo do período de operação de R9 $\left(750 \mathrm{~g} ; 50 \% ; 45^{\circ} \mathrm{C}\right)$, os principais compostos detectados foram os ácidos butírico, acético e propiônico, respectivamente (Figura 5.14A-C), cujas concentrações máximas detectadas foram de aproximadamente 775 e $455 \mathrm{mg} / \mathrm{L}$ para os ácidos butírico e acético, respectivamente (Figura 5.14A) e de ácido propiônico de $\sim 380 \mathrm{mg} / \mathrm{L}$ (Figura 5.14A).

Bactérias produtoras de ácido propiônico já foram anteriormente reportadas como dominantes em condições de estresse ambiental, como por exemplo carga orgânica elevada (SAADY, 2013). A elevada massa de papel adicionada em R9 (750 g), juntamente com o teor de umidade reduzido (65\%) pode ter sido um fator de estresse para as bactérias do consórcio microbiano. Além disso, a temperatura possivelmente influenciou a comunidade microbiana, já que nas operações mesofílicas R1 ( 400 mg/L) e R2 ( $800 \mathrm{mg} / \mathrm{L})$, as concentrações de ácido propiônico observadas foram bem reduzidas com relação aos ácidos acético e butírico.

Em contrapartida, na operação termofílica R5 $\left(1000 \mathrm{~g} ; 80 \% ; 55^{\circ} \mathrm{C}\right)$, também foi observada concentração expressiva de ácido propiônico, com concentração máxima de $\sim 5.000 \mathrm{mg} / \mathrm{L}$ ao longo do período de operação. Observa-se por meio desses resultados que o aumento da temperatura de 35 para 45 e até $55^{\circ} \mathrm{C}$ foi um fator que levou à alteração da comunidade microbiana, favorecendo o desenvolvimento de bactérias produtoras de ácido propiônico. 
A produção de álcoois, mais especificamente de etanol e metanol, também foi detectada ao longo do período de operação. As concentrações máximas desses compostos foram de aproximadamente 56 e $46 \mathrm{mg} / \mathrm{L}$, respectivamente, no $26^{\circ}$ dia de operação (Figura 5.14C). 


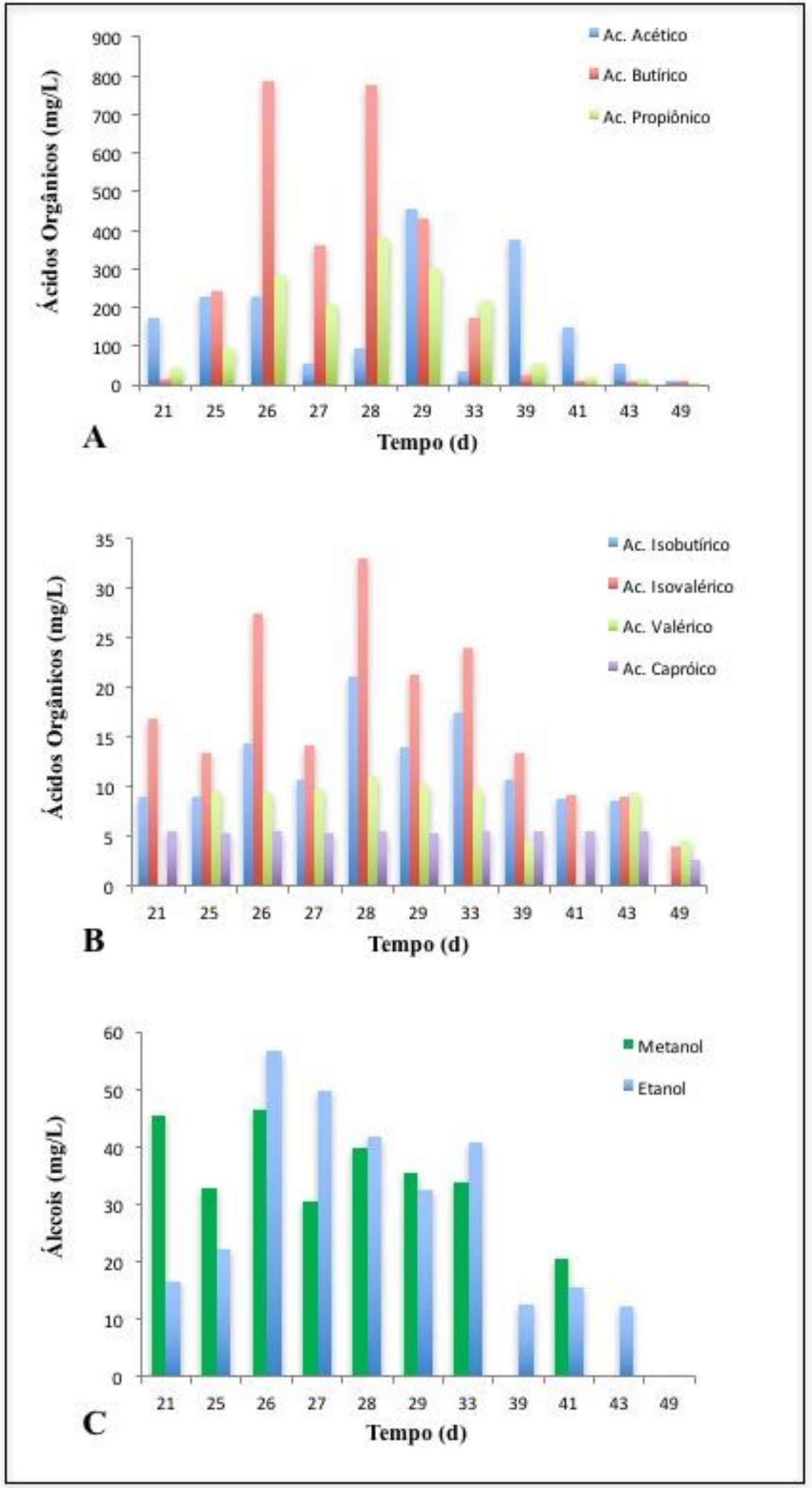

Figura 5.14 - Compostos orgânicos solúveis no percolado de R9

(750 g; 50\%; $\left.4^{\circ} \mathrm{C}\right)$. (A) Ácidos orgânicos: acético, butírico e propiônico; (B) Ácidos orgânicos: isobutírico, isovalérico, valérico e caproico; (C) Álcoois: etanol e metanol 
Em R10 (750 g; 50\%; 45 C), a produção de compostos orgânicos em meio líquido foi semelhante àquela observada em R9 $\left(750 \mathrm{~g} ; 50 \% ; 45^{\circ} \mathrm{C}\right)$. Concentrações bem reduzidas de ácidos orgânicos voláteis e álcoois foram detectadas durante a operação (Figura 5.15A-C). Neste lisímetro, semelhante a R9, sua replicata, os principais compostos produzidos foram ácidos acético, propiônico e butírico, respectivamente. As concentrações máximas destes compostos ao longo do período analisado foram de aproximadamente 970, 650 e $460 \mathrm{mg} / \mathrm{L}$, respectivamente (Figura 5.15A). Ou seja, nesses reatores, foi passível de ocorrer hidrólise de papel, porém a atividade fermentativa pareceu atenuada se comparada com as operações anteriores. 


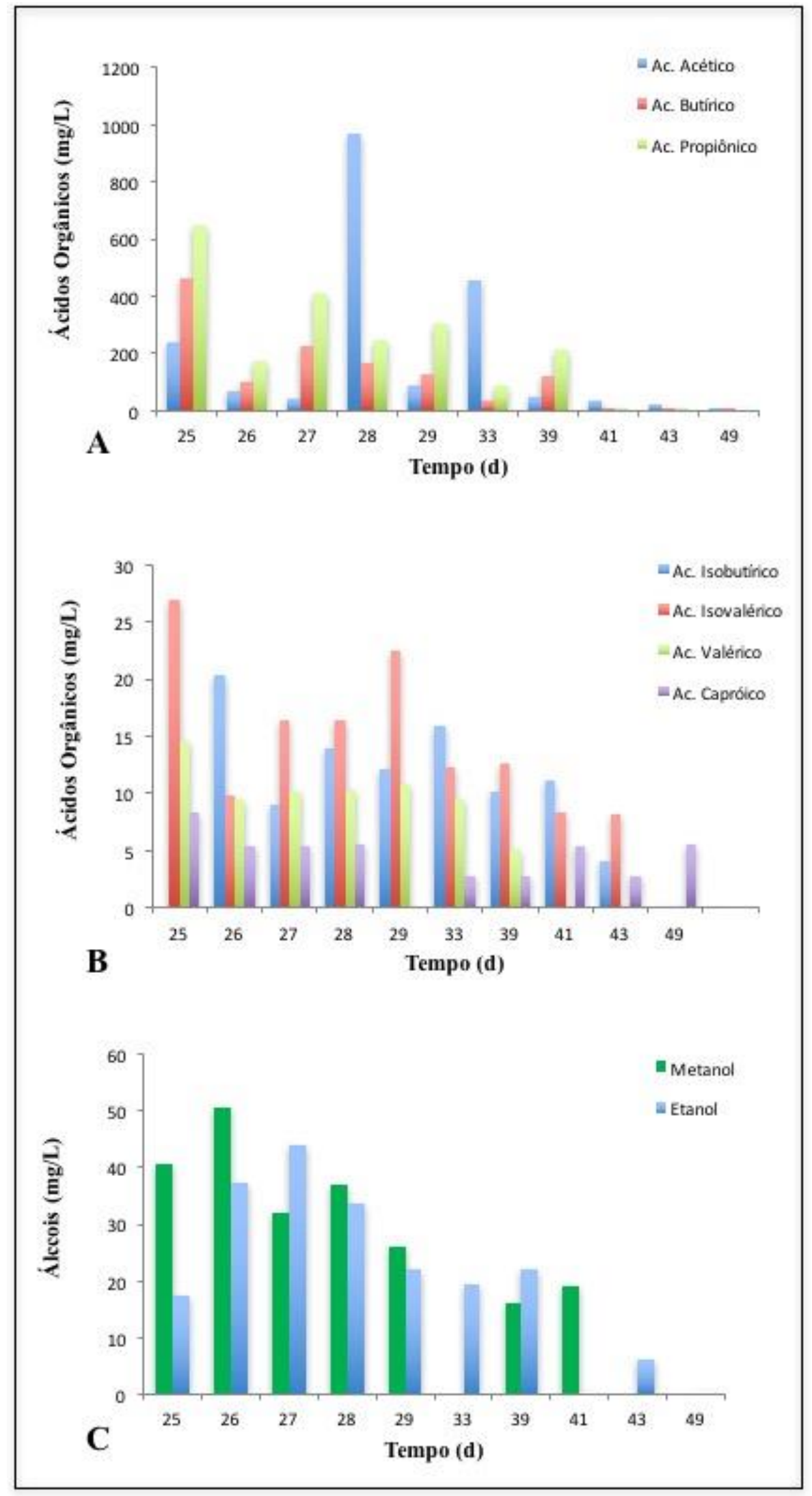

Figura 5.15 - Compostos orgânicos solúveis no percolado de R10 $\left(750 \mathrm{~g} ; 50 \% ; 4^{\circ} \mathrm{C}\right)$. (A) Ácidos orgânicos: acético, butírico e propiônico; (B) Ácidos orgânicos: isobutírico, isovalérico, valérico e caproico; (C) Álcoois: etanol e metanol 
Baixos rendimentos de hidrogênio são resultantes quando compostos orgânicos mais reduzidos, como ácido propiônico e etanol, são produzidos, porque eles representam os produtos finais de vias metabólicas não envolvidas com a produção de hidrogênio durante a fermentação de carboidratos, ou requerem hidrogênio para a sua formação (ANGENENT et al., 2004):

(1) Fermentação a etanol: metabolismo não relacionado com a produção de hidrogênio, porém de biocombustível líquido na forma de etanol

$\mathrm{C}_{6} \mathrm{H}_{12} \mathrm{O}_{6} \rightarrow 2 \mathrm{CH}_{3} \mathrm{CH}_{2} \mathrm{OH}+2 \mathrm{CO}_{2}$

(2) Produção de etanol com consumo de hidrogênio

$\mathrm{CH}_{3} \mathrm{COOH}+\mathrm{H}_{2} \rightarrow 2 \mathrm{CH}_{3} \mathrm{CH}_{2} \mathrm{OH}+2 \mathrm{H}_{2} \mathrm{O}$

(3) Produção de ácido propiônico com consumo de hidrogênio

$$
\mathrm{C}_{6} \mathrm{H}_{12} \mathrm{O}_{6}+2 \mathrm{H}_{2} \rightarrow 2 \mathrm{CH}_{3} \mathrm{CH}_{2} \mathrm{COOH}+2 \mathrm{H}_{2} \mathrm{O}
$$

A geração de ácido acético e ácido butírico em todas as condições estudadas provavelmente foi acompanhada pela geração de hidrogênio, porém o hidrogênio pode ter sido consumido em meio líquido durante a produção de compostos reduzidos, por exemplo. Neste estudo, as operações mesofílicas, nas quais foi observada maior evolução de hidrogênio, apresentaram concentrações reduzidas de ácido propiônico se comparadas àquelas observadas para os ácidos acético e butírico, por exemplo.

Nas outras condições estudadas, com aumento da temperatura de incubação para $45^{\circ} \mathrm{C}$ e $55^{\circ} \mathrm{C}$, em que houve menor produção de hidrogênio ou produção abaixo do nível de detecção, a produção de ácido propiônico foi mais expressiva.

Em R5 e R6, as concentrações de ácido propiônico foram acentuadas, enquanto que em R9 e R10 foram observadas concentrações semelhantes dos ácidos acético, propiônico e butírico. Estes resultados contradizem relato de Sivagurunathan, Zen e Lin (2014) de que o aumento da temperatura de $37^{\circ} \mathrm{C}$ para $45^{\circ} \mathrm{C}$ atenuou a produção de ácido propiônico, com desaparecimento das bactérias produtoras desse composto na cultura, levando ao aumento dos rendimentos de hidrogênio no reator. Esses autores utilizaram inóculo advindo de compostagem enquanto neste estudo utilizou-se fluido de rúmen, ou seja, possivelmente tratam-se de diferentes populações microbianas predominantes na microbiota. 
Atualmente, tem-se considerado que a produção de compostos orgânicos de elevado valor agregado, como os ácidos orgânicos voláteis, por exemplo, é mais viável do que a produção de hidrogênio a partir de resíduos ou águas residuárias ricas em carboidratos (ANGENENT et al., 2004). O ácido acético, por exemplo, obtido da fermentação do leite, foi purificado para ser utilizado como sal de degelo. Ademais, ácido acético tem sido descrito como substrato modelo para células a combustível microbianas (WAN; REN, 2014). Neste estudo, em todas as operações realizadas no lisímetro, sob as condições testadas, o ácido acético foi um dos principais compostos orgânicos detectados no percolado.

Elevados rendimentos de ácidos orgânicos voláteis $(0,59 \mathrm{~g} / \mathrm{g} \mathrm{SV})$ foram obtidos por meio de fermentação de palha de milho usando-se micro-organismos do rúmen como inóculo a $40^{\circ} \mathrm{C}$, com baixa porcentagem de hidrogênio no biogás (HU; YU, 2005). Fluido de rúmen também foi aplicado como inóculo para a produção de ácidos voláteis a partir de taboa, e foram obtidos, principalmente, ácido acético, ácido propiônico e ácido butírico, além de baixas concentrações de i-butirato, i-valerato e valerato (HU; YU, ZHENG, 2006). Os resultados relatados nestas pesquisas estão em conformidade com os obtidos no presente estudo, visto que concentrações representativas de ácidos orgânicos voláteis foram produzidas ao longo das operações dos lisímetros, em especial ácidos acético, butírico e propiônico.

\subsection{Análise Estatística do Delineamento Composto Central (Fatorial $2^{3}$ )}

Para examinar os efeitos de 3 variáveis independetes na produção de hidrogênio, um delineamento composto central (fatorial $2^{3}$ ) de 8 (R1-R8) experimentos foi realizado com as diferentes combinações, e 2 experimentos (R9 e R10) foram conduzidos nas condições do ponto central, como replicatas.

Devido à prevalência de ácido acético, etanol e metanol no percolado, estes compostos também foram selecionados como variáveis resposta do delineamento composto central. O ajuste do modelo também foi expresso como o coeficiente de determinação, $\mathrm{R}^{2}$, que foi de $89,4 \%$ para o hidrogênio, $82,7 \%$ para o ácido acético, $48,1 \%$ para o etanol e 59,6\% para o metanol. A Tabela 5.6 lista os resultados empíricos máximos detectados para estes quatro compostos em todas as condições aplicadas nos lisímetros R1 a R10. 
Tabela 5.6 - Valores empíricos das variáveis respostas monitoradas durante a fermentação acidogênica do papel nos lisímetros nas diferentes condições de processo aplicadas

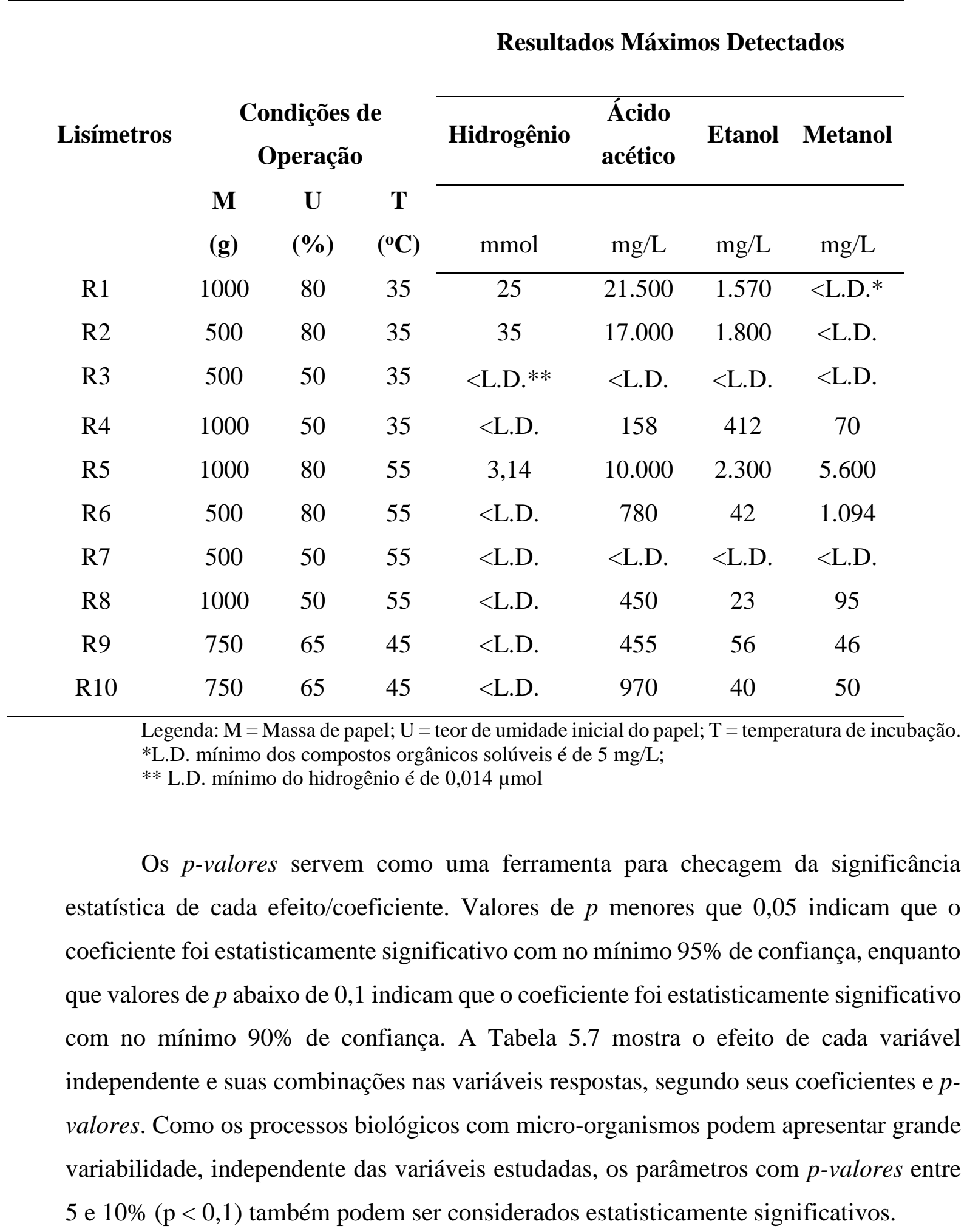


Analisando-se a tabela de coeficientes das variáveis independentes e suas combinações sobre as variáveis respostas, pode-se observar que a massa de substrato (X1) não teve efeito estatisticamente significativo sobre nenhuma das variáveis respostas, tanto a $95 \%$ de confiança, quanto a $90 \%$ de confiança, visto que todos os p-valores foram acima de 0,05 e 0,1 , respectivamente (Tabela 5.7). A partir deste resultado pode-se inferir que a geração dos produtos monitorados durante a fermentação não foi influenciada pela massa de substrato adicionada inicialmente.

Já em relação à temperatura de incubação (X3), verificou-se efeito negativo estatisticamente significativo, com $90 \%$ de confiança, sobre a produção de hidrogênio e a produção de ácido acético, ou seja, o aumento da temperatura levou à redução da produção destes compostos (Tabela 5.7).

Sobre a produção de etanol e metanol, por sua vez, a temperatura de incubação não teve influência com significância estatística, ou seja, a produção desses compostos foi independente da temperatura utilizada (Tabela 5.7).

Dentre as três variáveis independentes estudadas, o teor de umidade do substrato (X2) foi a que mais teve efeito na fermentação acidogênica do papel, pois este foi estatisticamente significativo em três variáveis resposta. Em relação ao hidrogênio, o aumento do teor de umidade de 50 a $80 \%$ acarretou aumento de sua produção, ou seja, o efeito da umidade foi positivo a 95\% de confiança (Tabela 5.7). O mesmo foi observado para o ácido acético, já que o aumento da umidade influenciou positivamente a produção deste composto, com 95\% de confiança (Tabela 5.7). A produção de etanol também foi favorecida com o aumento do teor de umidade inicial do papel, com efeito positivo estatisticamente significativo a $90 \%$ de confiança (Tabela 5.7).

O metanol foi a única variável resposta cuja produção não foi influenciada positiva ou negativamente com significância estatística por nenhuma das variáveis independentes estudadas neste planejamento experimental. A ocorrência de metanol em apenas duas condições inviabilizou a construção de um modelo estatístico que descrevesse a produção deste composto dentro das faixas estudadas de massa, umidade e temperatura.

Em relação aos efeitos de interação, ou seja, o efeito das variáveis combinadas entre si, não foi observado efeito de interação positivo ou negativo, estatisticamente significativo, das variáveis massa e umidade em nenhuma das respostas monitoradas (Tabela 5.7). O mesmo foi observado para o efeito de interação das variáveis massa e temperatura. Isso significa que o aumento da massa de substrato somado ao aumento do 
teor de umidade não teve efeito estatisticamente significativo sobre a produção dos compostos analisados. Similarmente, o aumento da massa juntamente com o aumento da temperatura também não acarretou efeito estatisticamente significativo sobre as variáveis respostas (Tabela 5.7). O único efeito de interação observado com significância estatística foi sobre a produção de ácido acético. O efeito foi negativo, a 90\% de confiança, para a geração deste ácido com o aumento do teor de umidade do substrato e da temperatura de incubação. Para as outras variáveis respostas, não foi observado efeito de interação X2xX3 estatisticamente significativo (Tabela 5.7).

Em relação à redução do teor de umidade do substrato observou-se diminuição da conversão de substrato, refletida pelas concentrações reduzidas de metabólitos solúveis resultantes da fermentação no percolado, porém sem mudanças significativas nas rotas metabólicas desempenhadas pelos micro-organismos nas condições estudadas. Com a caracterização da composição de compostos orgânicos voláteis de todas as condições de operação aplicadas no lisímetro, pôde-se verificar que o fator temperatura mesofílica e termofílica foi mais determinante para as rotas metabólicas do que o teor de umidade, já que o perfil de compostos de R1, R2 e R4 foi semelhante da mesma maneira que isto ocorreu para R5, R6 e R8.

Em relação à produção de hidrogênio, esta foi somente detectada nas operações cujo teor de umidade do papel foi de $80 \%$ (R1, R2 e R5). O efeito da concentração de sólidos totais (referente ao substrato) muito elevada em relação ao teor de água na digestão anaeróbia de resíduos foi também relatado por Abassi-Guendouz et al. (2012), usando papelão como substrato em ensaios em batelada com teor de sólidos totais variando de 10 a 35\%. Staley, De Los Reyes III e Barlaz (2011), também verificaram esse mesmo comportamento para resíduos sólidos residenciais. Em ambos os estudos, foi observada grande inibição da biodigestão com ausência da produção de metano. Os autores atribuíram este fato ao acúmulo de ácidos orgânicos voláteis. Neste estudo, elevadas concentrações de ácidos orgânicos voláteis foram verificadas especialmente em R1, R2 e R5, o que pode explicar a baixa conversão de papel à hidrogênio sob as condições impostas no sistema.

Abassi-Guendouz et al. (2012) investigaram os efeitos da hidrólise e transferência de massa líquido/gás em sistemas com elevado teor de sólidos totais, ou seja, baixo teor de umidade e disponibilidade reduzida de água. As simulações no modelo "The anaerobic digestion model No 1 (ADM 1)" resultaram que há uma limitação na transferência de massa que poderia explicar a produção reduzida de metano em condições de elevado teor 
de sólidos totais $(\mathrm{ST}>30 \%$ ), e que a constante de velocidade de hidrólise decresceu levemente com o aumento dos sólidos totais. De acordo com resultados obtidos do modelo, a limitação da transferência de massa resultou em acúmulo de metano, hidrogênio e gás carbônico dissolvidos, que pode ter efeito inibitório na metanogênese. Apesar do estudo ter sido realizado com base na biogestão, com foco na produção de metano, provavelmente neste estudo também houve acúmulo de hidrogênio e gás carbônico no meio líquido levando à geração de elevadas concentrações de ácido acético e ácido propiônico.

Hyaric et al. (2011) estudaram a influência da concentração de substrato e do teor de umidade, usando o material digerido de uma planta de biodigestão de resíduos sólidos urbanos como substrato em ensaios em batelada com duração média de 25 dias. Para o acerto de $65 \%$ e $82 \%$ de umidade, foi feito um mix de material fresco e seco (após secagem overnight a $105^{\circ} \mathrm{C}$ ), totalizando $200 \mathrm{~g}$, somado à adição de $5 \mathrm{~g} / \mathrm{L}$ de ácido propiônico. Foi observado que a atividade metanogênica específica cresceu linearmente por um fator de 3,5 com o aumento do teor de umidade do substrato de $65 \%$ para $82 \%$, correspondendo a $35 \%$ e $18 \%$ sólidos totais, respectivamente. Há relatos de que quando se aumenta a concentração de sólidos totais em reatores, a agitação (ou mistura) se torna importante para promover a produção de metano. Em condições em que não há essa agitação, o transporte das moléculas de gás é extremamente relacionado à porosidade do meio, e, portanto, ao teor de água. Portanto, a resistência dessa difusão de compostos, tanto substratos quanto subprodutos, acarreta grande influência da digestão anaeróbia em sistemas secos (KARIM et al., 2005).

Assim, apesar das vantagens de sistemas semissólidos e sólidos no que se refere à economia de água e redução no volume de efluente gerado e do sistema como um todo, a operação apresenta dificuldades relacionadas às elevadas concentrações de sólidos totais. 
Tabela 5.7 - Análise da significância estatística dos efeitos das variáveis (X) sobre as respostas (Y)

\begin{tabular}{|c|c|c|c|c|c|c|c|c|}
\hline \multirow[t]{3}{*}{ Resposta } & \multicolumn{2}{|c|}{ Y1 } & \multicolumn{2}{|c|}{ Y2 } & \multicolumn{2}{|c|}{ Y3 } & \multicolumn{2}{|c|}{ Y4 } \\
\hline & \multicolumn{2}{|c|}{ Hidrogênio } & \multicolumn{2}{|c|}{ Ácido acético } & \multicolumn{2}{|c|}{ Etanol } & \multicolumn{2}{|c|}{ Metanol } \\
\hline & Coeficiente & $p$-valor & Coeficiente & $p$-valor & Coeficiente & $p$-valor & Coeficiente & $p$-valor \\
\hline Média & 6,31 & 0,0516 & 5110,19 & 0,0293 & 629,518 & 0,0882 & 697,15 & 0,1368 \\
\hline X1 & $-0,86$ & 0,7282 & 1800,41 & 0,3035 & 298,31 & 0,3682 & 585,84 & 0,2265 \\
\hline $\mathbf{X} 2$ & 7,89 & 0,0392 & 6057,61 & 0,0251 & 665,51 & 0,0996 & 817,64 & 0,1245 \\
\hline $\mathbf{X 3}$ & $-7,11$ & 0,0508 & $-3419,98$ & 0,1000 & $-185,70$ & 0,5576 & 841,53 & 0,1174 \\
\hline $\mathrm{X} 1 \times \mathrm{X} 2$ & $-0,86$ & 0,7282 & 1648,55 & 0,3391 & 189,48 & 0,5501 & 544,18 & 0,2535 \\
\hline $\mathrm{X} 1 \times \mathrm{X} 3$ & 1,64 & 0,5178 & 598,93 & 0,7079 & 269,09 & 0,4108 & 568,07 & 0,2376 \\
\hline $\mathrm{X} 2 \times \mathrm{X} 3$ & $-7,11$ & 0,0508 & $-3492,89$ & 0,0956 & $-88,48$ & 0,7745 & 835,42 & 0,1192 \\
\hline
\end{tabular}

Legenda: X1: Massa de Substrato (g); X2: Teor de Umidade do Substrato (\%); X3: Temperatura de Incubação $\left({ }^{\circ} \mathrm{C}\right)$.

Com no mínimo 95\% de confiança

Entre 90 e $95 \%$ de confiança 
Os modelos matemáticos são úteis para interpolar valores, ou seja, determinar condições dentro de uma faixa estudada. Estimar uma condição ótima dentro de uma faixa estudada. O teste ANOVA com os dados do delineamento experimental deve ser realizado para se obter o valor de Fcalculado e compará-lo ao Fcrítico. Assim, verificase o modelo é estatisticamente significativo, se representa o delineamento experimental. Quando Fcalculado > Fcrítico, o modelo é estatisticamente significativo, e portanto, representa os dados experimentais. O modelo matemático, de primeira ordem, está descrito da Equação 11, na qual as variáveis são expressas como seus valores codificados. $\beta_{0,} \beta_{1}, \beta_{2}, \beta_{3}, \beta_{12,} \beta_{13}, \beta_{23}$ são parâmetros do modelo de regressão.

$$
Y=\beta_{0}+\beta_{1} X_{1}+\beta_{2} X_{2}+\beta_{3} X_{3}+\beta_{12} X_{1} X_{2}+\beta_{13} X_{1} X_{3}+\beta_{23} X_{2} X_{3}+e
$$

A partir dos valores obtidos para as respostas estudadas, foi possível construir o modelo de cada variável, a partir das variáveis codificadas, considerando apenas os parâmetros estatisticamente significativos (analisados pelo coeficiente). Os modelos, os valores em termos de variação explicada $\left(\mathrm{R}^{2}\right)$, e os valores Fcal e Ftab para as quatro respostas estão apresentados na Tabela 5.8.

Tabela 5.8 - Modelos matemáticos de cada variável resposta com os parâmetros estatisticamente significativos, valores de porcentagem de variação explicada $\left(R^{2}\right)$ e Fcal para as respostas segundo as condições do DCC

\begin{tabular}{ccccc}
\hline Respostas & Modelo* & $\mathbf{R}^{2}$ & Fcal & Ftab \\
\hline Hidrogênio & $\mathrm{Y}_{1}=6,31+7,89 \mathrm{x}_{2}-7,11 \mathrm{x}_{3}-7,11 \mathrm{x}_{2} \mathrm{x}_{3}$ & 89,4 & 16,9 & 3,29 \\
Ácido Acético & $\mathrm{Y}_{2}=5110,19+6057,61 \mathrm{x}_{2}-3419,98 \mathrm{x}_{3}-3492,89 \mathrm{x}_{2} \mathrm{x}_{3}$ & 82,7 & 9,6 & 3,29 \\
Etanol & $\mathrm{Y}_{3}=629,52+665,51 \mathrm{x}_{2}$ & 48,1 & 7,4 & 3,46 \\
Metanol $^{* *}$ & $\mathrm{Y}_{4}=697,15+817,64 \mathrm{x}_{2}+841,53 \mathrm{x}_{3}+835,42 \mathrm{x}_{2} \mathrm{x}_{3}$ & 59,6 & 2,9 & 3,29 \\
\hline
\end{tabular}

*Modelos reparametrizados: os coeficientes não estatisticamente significativos foram retirados, ou seja, só foram consideradas variáveis independentes relevantes para cada resposta.

**Os coeficientes considerados para a construção do modelo de metanol tiveram significância estatística entre 85 e $90 \%$ (p-valor de entre 0,1 e 0,15), do contrário não haveria modelo para este composto.

Os valores de $\mathrm{R}^{2}$ e Fcal foram razoáveis para as respostas Hidrogênio e Ácido acético. No entanto, para as respostas Etanol e Metanol, estes valores foram abaixo do 
desejado, pois não houve grande variabilidade na produção destes compostos dentro das faixas estudadas de cada variável independente.

Assim, foram construídas as superfícies de resposta e as curvas de contorno com as variáveis relevantes para cada resposta (ou seja, somente aquelas que entraram no modelo), a fim de avaliar as condições das variáveis que levaram à maior produção dos compostos estudados. Usando-se esta representação, as interações entre duas variáveis e seus pontos ótimos são facilmente identificadas

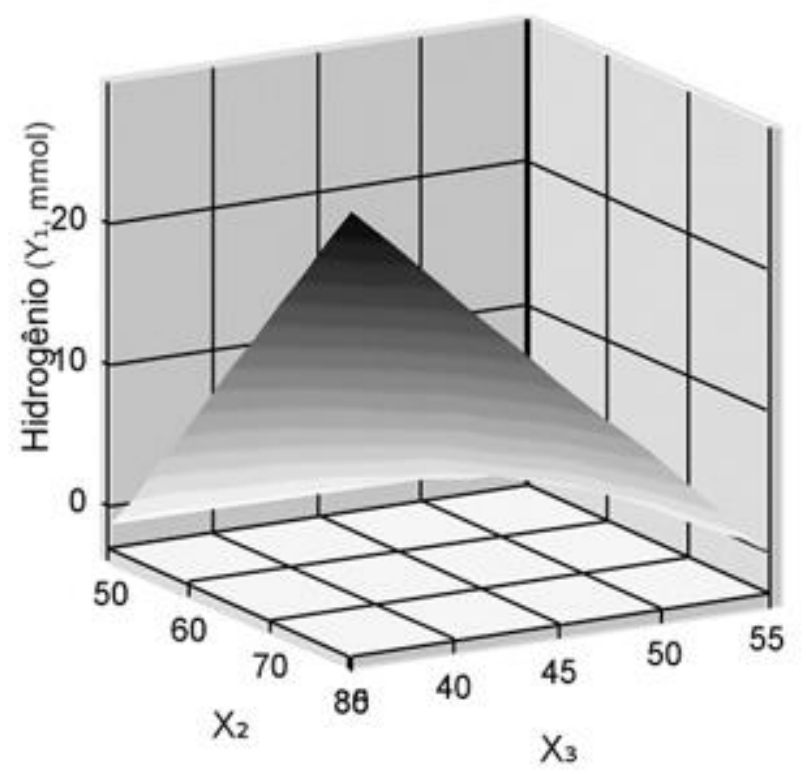

Figura 5.16 - Superfície de Resposta para a Resposta Hidrogênio, em função do teor de umidade do substrato (X2) e temperatura de incubação (X3) 


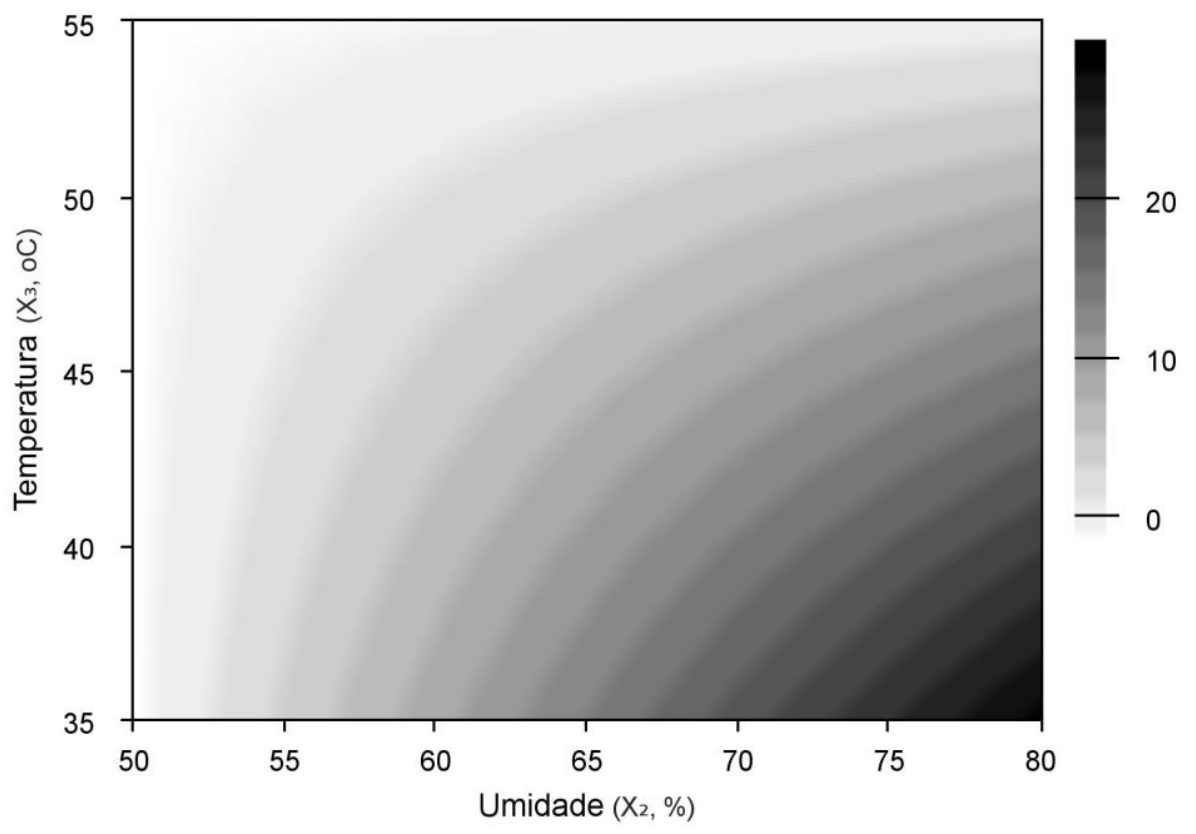

Figura 5.17 - Curva de contorno para a Resposta Hidrogênio, em função do teor de umidade do substrato (X2) e temperatura de incubação (X3)

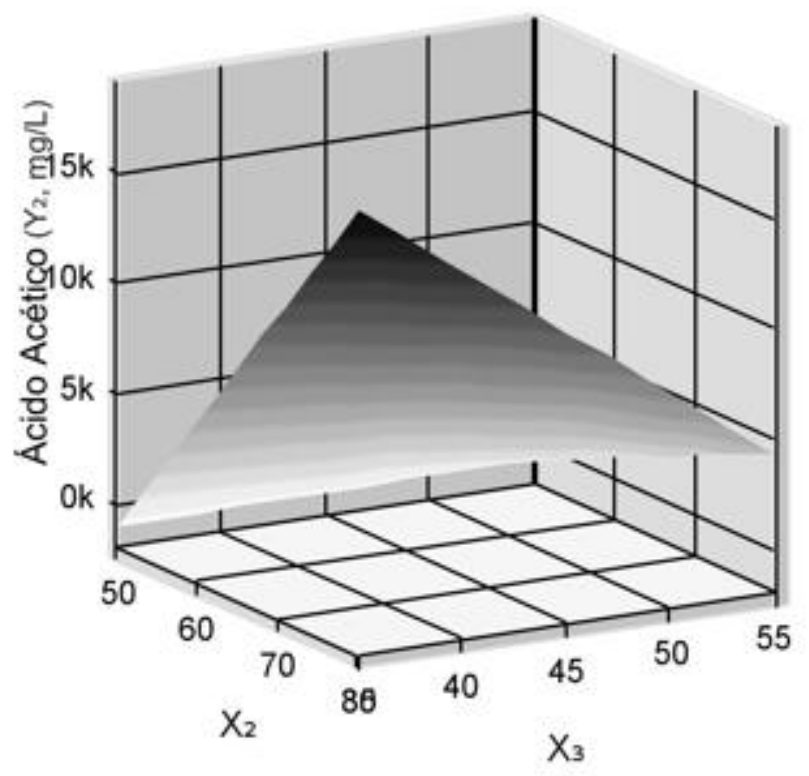

Figura 5.18 - Superfície de Resposta para a Resposta Ácido Acético, em função do teor de umidade do substrato (X2) e temperatura de incubação (X3) 


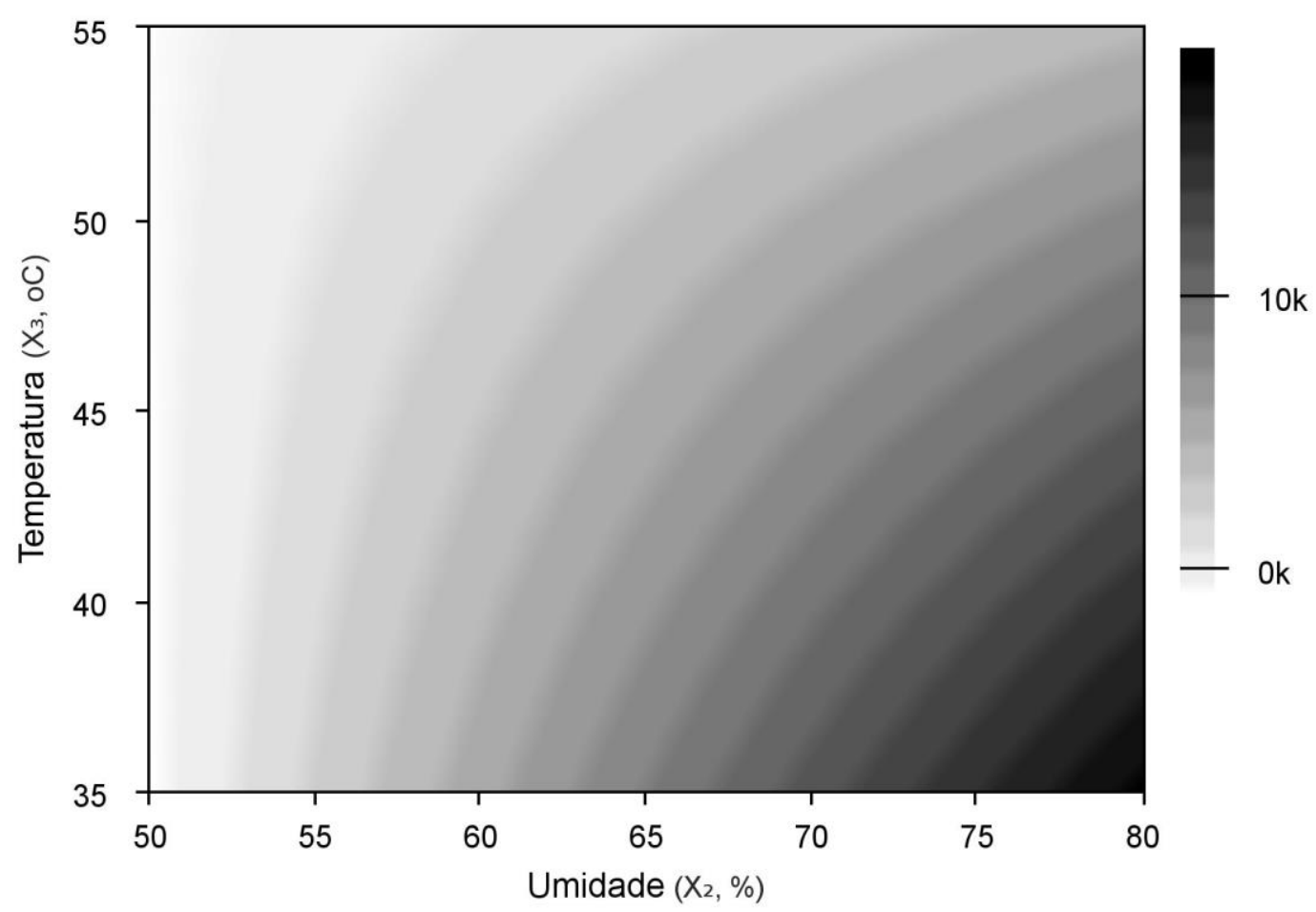

Figura 5.19 - Curva de contorno para a Resposta Ácido acético, em função do teor de umidade do substrato (X2) e temperatura de incubação (X3)

Pelas curvas de contorno, pôde-se concluir que para promover a produção de hidrogênio, as condições que devem ser aplicadas são teor de umidade elevado, na faixa de 75 a $80 \%$, e temperatura de incubação na faixa mesofílica de 35 a $37^{\circ} \mathrm{C}$, por exemplo (Figuras 5.16 e 5.17). As mesmas condições devem ser aplicadas para o favorecimento da produção de ácido acético, conforme Figuras 5.18 e 5.19, ou seja, teor umidade de $80 \%$ e temperatura na faixa mesofílica.

Neste estudo houve uma falta de ajuste para etanol e metanol, representado pelo valor de $\mathrm{R}^{2}$ muito reduzido, além de Fcal ter sido menor que Ftab. Portanto, seria necessário propor um novo modelo, o que levaria a um novo delineamento experimental com outra faixa de valores (níveis) a ser considerada. Neste estudo, não se verificou variação na produção destes compostos dentre as faixas de massa de papel, teor de umidade e temperatura consideradas no delineamento.

Verifica-se pela Figura 5.20A que tanto concentrações menores de 0 a 500 mg/L de etanol, quanto concentrações mais altas de 1.500 a $2.500 \mathrm{mg} / \mathrm{L}$ foram observadas para ambas massas de papel estudadas 500 e 1.000 g. Ou seja, não se verificou um favorecimento da produção de etanol para uma dada massa de papel adicionada (Figura 
5.20A). Já o teor de umidade apresentou efeito sobre a produção de etanol, visto que concentrações mais elevadas de etanol, acima de $1.500 \mathrm{mg} / \mathrm{L}$, só foram detectadas nos lisímetros operados com teor de umidade de 80\% (Figura 5.20B). Assim, a análise estatística mostrou o efeito positivo da umidade sobre a produção de etanol. Em relação à variável temperatura, é possível avaliar pela Figura $5.20 \mathrm{C}$ que a produção de concentrações similares de etanol foi observada tanto a $35^{\circ} \mathrm{C}$ quanto a $55^{\circ} \mathrm{C}$, ou seja, não houve favorecimento de uma das condições de temperaturap; sobre a produção de etanol, fazendo desta variável sem efeito estatisticamente significativo, conforme Tabela 5.7. 


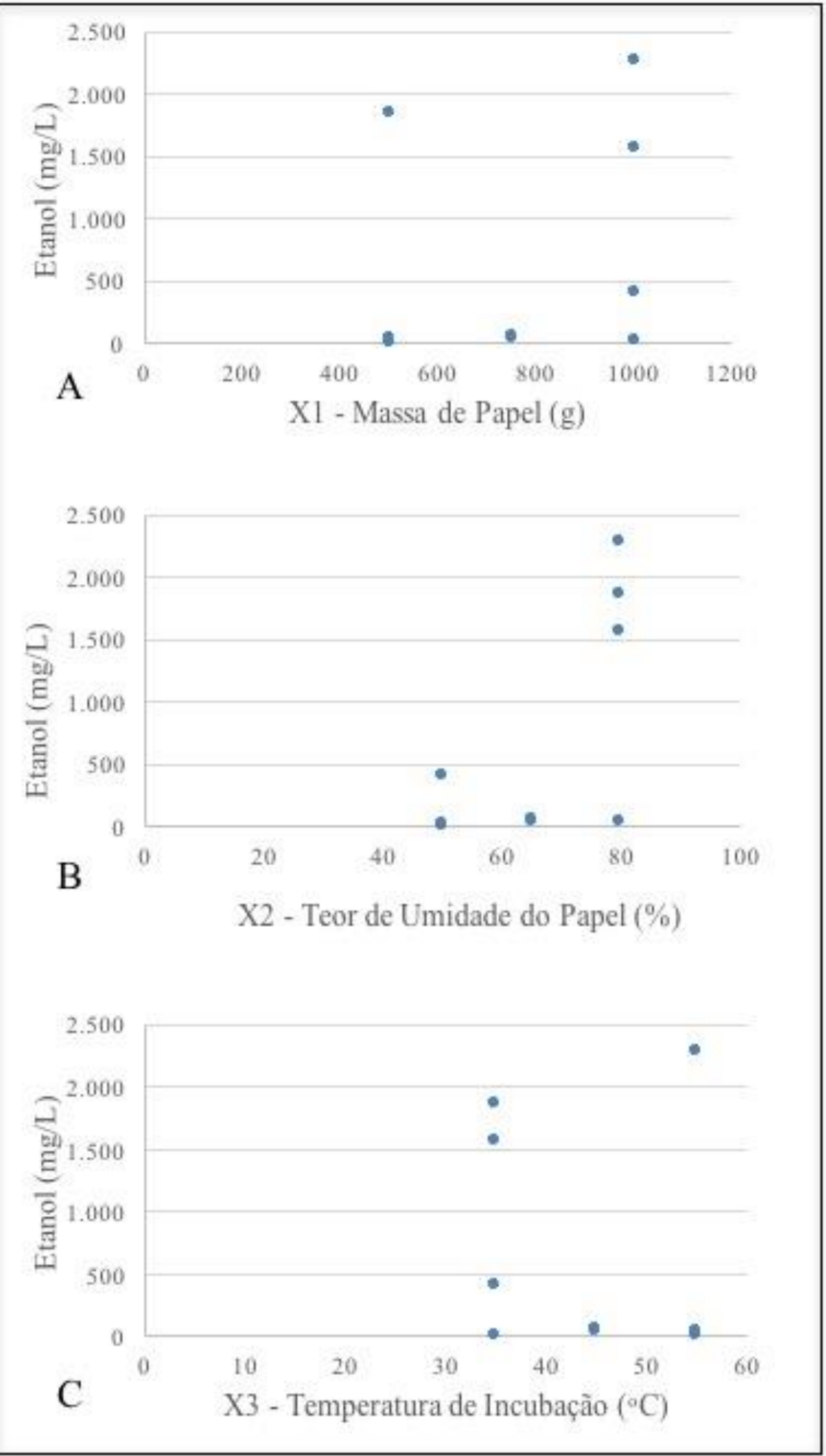

Figura 5.20 - Produção de Etanol em função da Massa de papel adicionada (A); teor de umidade do papel (B) e temperatura de operação (C) 
5.4.1 Caracterização físico-química do percolado

A caracterização físico-química do percolado dos lisímetros, em relação ao teor de matéria orgânica total e solúvel (DQO total e solúvel), carboidratos totais e solúveis, $\mathrm{pH}$, série de sólidos totais e alcalinidade foi possível após a liberação de volume de percolado viável para a realização destas análises. Na Tabela 5.9 estão listados a partir de qual período foi possível fazer este monitoramento do percolado nas condições estudadas.

\section{lisímetros}

Tabela 5.9 - Período em que houve a primeira detecção de percolado nos

Lisímetro

$\begin{array}{lc}\text { R1 }\left(1000 \mathrm{~g} ; 80 \% ; 35^{\circ} \mathrm{C}\right) & 21 \\ \text { R2 }\left(500 \mathrm{~g} ; 80 \% ; 35^{\circ} \mathrm{C}\right) & 21 \\ \text { R3 }\left(500 \mathrm{~g} ; 50 \% ; 35^{\circ} \mathrm{C}\right) & - \\ \text { R4 }\left(1000 \mathrm{~g} ; 50 \% ; 35^{\circ} \mathrm{C}\right) & 40 \\ \text { R5 }\left(1000 \mathrm{~g} ; 80 \% ; 55^{\circ} \mathrm{C}\right) & 15 \\ \text { R6 }\left(500 \mathrm{~g} ; 80 \% ; 35^{\circ} \mathrm{C}\right) & 15 \\ \text { R7 }\left(500 \mathrm{~g} ; 50 \% ; 55^{\circ} \mathrm{C}\right) & 28 \\ \text { R8 }\left(1000 \mathrm{~g} ; 50 \% ; 55^{\circ} \mathrm{C}\right) & 21 \\ \text { R9 }\left(750 \mathrm{~g} ; 65 \% ; 45^{\circ} \mathrm{C}\right) & 25 \\ \text { R10 }\left(750 \mathrm{~g} ; 65 \% ; 45^{\circ} \mathrm{C}\right) & \end{array}$

Por meio da DQO e carboidratos totais solúveis detectadas nos percolados dos lisímetros, em conjunto, é possível afirmar que houve atividade hidrolítica e fermentativa pela microbiota, ou seja, apesar dos teores reduzidos de umidade e da variação de temperatura, pôde-se observar a ocorrência de algum metabolismo fermentativo. Em todas as condições foi detectado açúcares solúveis no percolado, indicando hidrólise do papel, sendo este a única fonte orgânica adicionada nos lisímetros.

Em R1, os valores de DQO solúvel do percolado corresponderam com as concentrações elevadas de compostos orgânicos solúveis detectadas no efluente, resultantes da atividade fermentativa, atingindo valor máximo de aproximadamente $25.000 \mathrm{mg} \mathrm{O}_{2} / \mathrm{L}$ (Figura 5.21A). Os valores de DQO efluente reduziram conforme as concentrações de ácidos orgânicos e álcoois diminuíram no efluente, a partir do $22^{\circ}$ dia 
de operação. A taxa máxima de hidrólise de papel em açúcares solúveis provavelmente ocorreu nos primeiros dias de operação, com pico da concentração de carboidratos solúveis no início da operação, antes da liberação de percolado, como descrito nas Etapas I e II, e foi diminuindo ao longo do período de operação pela redução da atividade metabólica dos micro-organismos (Figura 5.22B). A concentração máxima de carboidratos solúveis em R1 foi de aproximadamente $1.000 \mathrm{mg} / \mathrm{L}$ (Figura 5.22B).

Os valores elevados de DQO solúvel em R2, que variaram de $25.300 \mathrm{mg} / \mathrm{L}$ no $17^{\circ}$ dia de operação a $8.800 \mathrm{mg} / \mathrm{L}$ ao final da operação também estão de acordo com as concentrações elevadas de compostos orgânicos solúveis no percolado, com uma redução detectada mais próxima no final do período de operação (Figura 5.21B). Em relação aos carboidratos totais solúveis, concentração máxima de $1.000 \mathrm{mg} / \mathrm{L}$ foi detectada no $17^{\circ}$ dia de operação (Figura 5.22B). Como citado anteriormente, um pico de açúcares solúveis provavelmente ocorreu nos primeiros dias de operação, porém não foi detectado pela ausência de percolado.

Durante a operação do R3, não houve liberação de percolado, já que o teor de umidade máximo atingido foi de 80,5\%. Portanto, as análises cromatográficas e físicoquímicas não foram realizadas.

Em R4, apesar de concentrações reduzidas de ácidos orgânicos no efluente de R4, refletindo baixa atividade metabólica por parte da microbiota do rúmen enriquecido, foram detectadas concentrações expressivas de açúcares solúveis, em torno de 9.000 $\mathrm{mg} / \mathrm{L}( \pm 316,2)$ no $40^{\circ}$ dia de operação, com redução significativa até o final da operação para $1.287 \mathrm{mg} / \mathrm{L}( \pm 0)$ (Figura 5.22B). Assim, as elevada DQO solúvel detectadas foram principalmente devidas ao teor de açúcares solúveis e não só ao teor de ácidos orgânicos voláteis, os quais foram observados em concentrações reduzidas. Verificou-se variação da DQO de 15.000 ( \pm 107$)$ a $11.300(45) \mathrm{mg} / \mathrm{L}$ do $40^{\circ}$ dia até o final da operação (Figura $5.21 \mathrm{~B})$. 


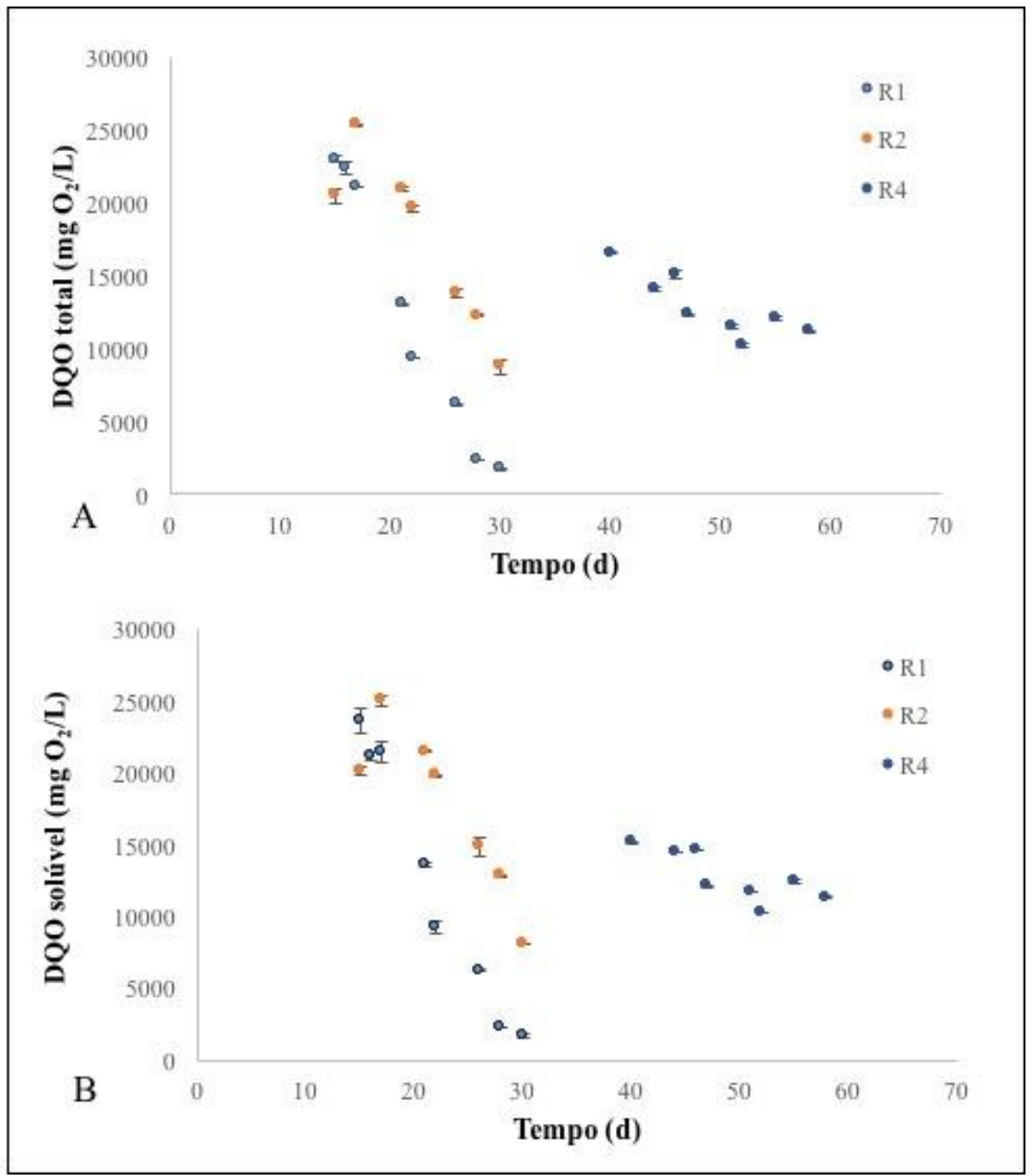

Figura 5.21 - Variação temporal da DQO total (A) e DQO solúvel (B) nos Lisímetros R1 (1000 g; 80\%; 35 C), R2 (500 g; 80\%; 35 C) e R4 (1000 g; $\left.50 \% ; 35^{\circ} \mathrm{C}\right)$ 


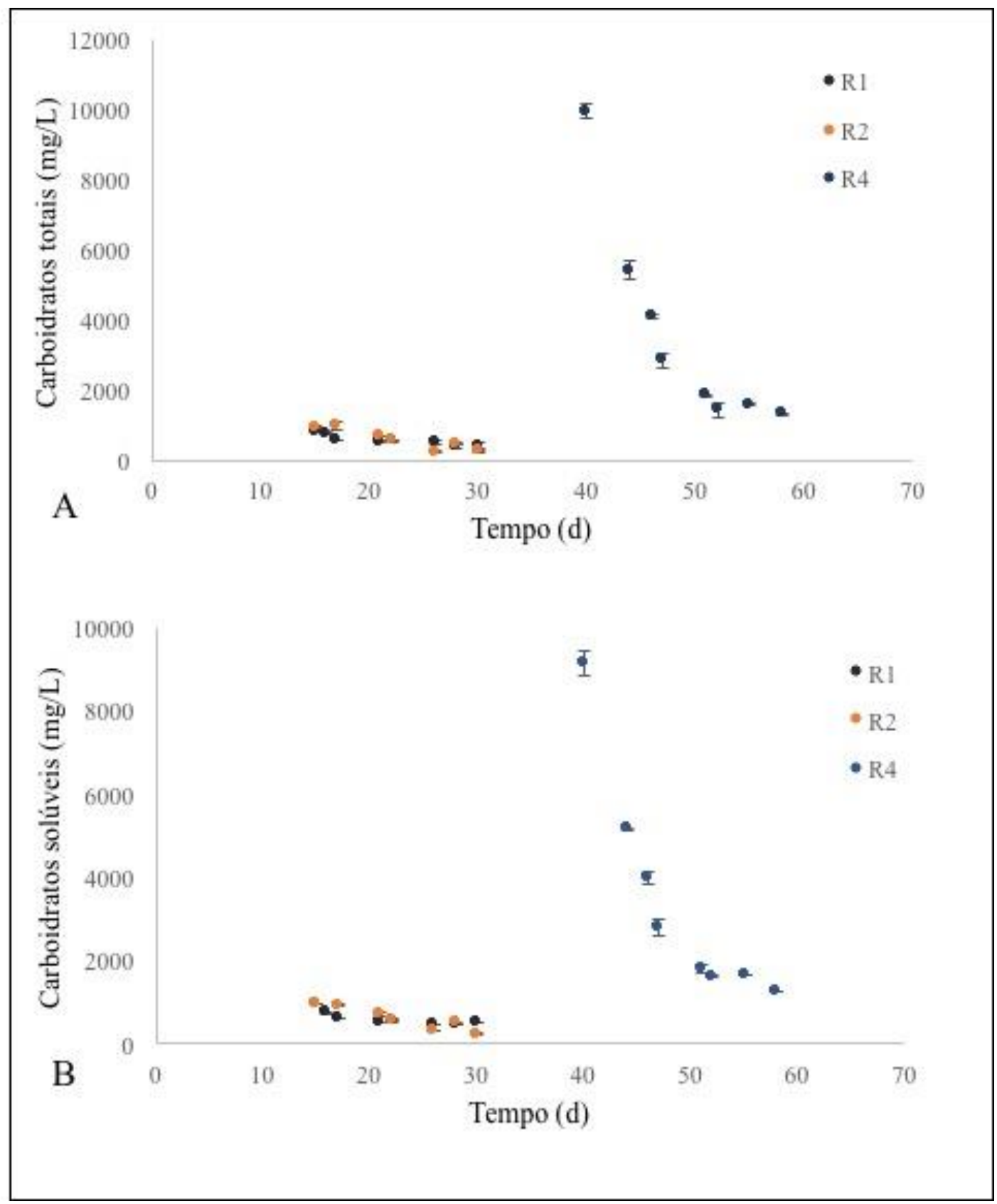

Figura 5.22 - Variação temporal das concentrações de Carboidratos totais (A) e Carboidratos solúveis (B) nos Lisímetros R1 (1000 g; 80\%; 35० C), R2 $\left(500 \mathrm{~g} ; 80 \% ; 3^{\circ} \mathrm{C}\right)$ e $\mathrm{R4}\left(1000 \mathrm{~g} ; 50 \% ; 35^{\circ} \mathrm{C}\right)$

Em R5, os valores de DQO solúvel foram elevados em conformidade com as concentrações de ácidos orgânicos e álcoois detectadas no percolado, e reduziram com a diminuição das concentrações desses compostos ao final da operação. Verificou-se variação da DQO solúvel de aproximadamente $24.000 \mathrm{mg} / \mathrm{L}$ no $22^{\circ}$ dia de operação à $4.400 \mathrm{mg} / \mathrm{L}$ no $37^{\circ}$ dia (Figura.5.23B). O monitoramento de carboidratos totais também decorreu no mesmo período de análise da DQO. Em temperatura termofílica, a 
capacidade hidrolítica da microbiota parece ter sido favorecida, já que concentrações de carboidratos solúveis superiores às detectadas em R1-R4 foram verificadas em R5 e R8, por exemplo. Em R5, foram observadas concentrações de até aproximadamente 1.200 $\mathrm{mg} / \mathrm{L}$ (Figura 5.24B), ligeiramente maior do que as concentrações máximas detectadas em R1 e R2.

Já em R6, as concentrações reduzidas de DQO solúvel vão de encontro com as menores concentrações de compostos orgânicos solúveis detectados neste lisímetro, em comparação com os anteriores (Figura 5.23B). Verificou-se que a DQO solúvel variou de $592( \pm 4,45)$ a $3.237( \pm 331,7) \mathrm{mg} / \mathrm{L}$, com pico no $18^{\circ}$ dia de operação $(3237,85 \pm 331,7)$, quando houve aumento nas concentrações dos ácidos acético e propiônico, por exemplo. Esse mesmo comportamento foi observado para os carboidratos totais solúveis, cuja concentração máxima detectada foi de $768( \pm 24,8) \mathrm{mg} / \mathrm{L}$ no $18^{\circ}$ dia de operação (Figura 5.24B). Ao longo da operação, verificou-se variação das concentrações de $316( \pm 0) \mathrm{mg} / \mathrm{L}$ no $15^{\circ}$ de operação, pico no $23^{\circ}$ dia, e $245( \pm 45) \mathrm{mg} / \mathrm{L}$ ao final da operação (Figura 5.24B).

Durante a operação de R7, não houve liberação de percolado, já que o teor de umidade máximo atingido foi de 55\%. Assim, não foi possível fazer a caracterização do percolado.

Em R8, verificou-se que a DQO solúvel do percolado foi elevada, com concentração média de aproximadamente $36.000 \mathrm{mg} / \mathrm{L}( \pm 5.178,42)$ durante o período analisado (Figura 5.23B). Dentre todas as operações realizadas, foi aquela em que verificou-se teor de DQO do percolado mais elevada. Verificou-se manutenção elevada da concentração de carboidratos totais solúveis ao longo do período analisado, de 25.470 $\pm 5.709,50 \mathrm{mg} / \mathrm{L}$ (Figura 5.24B). 


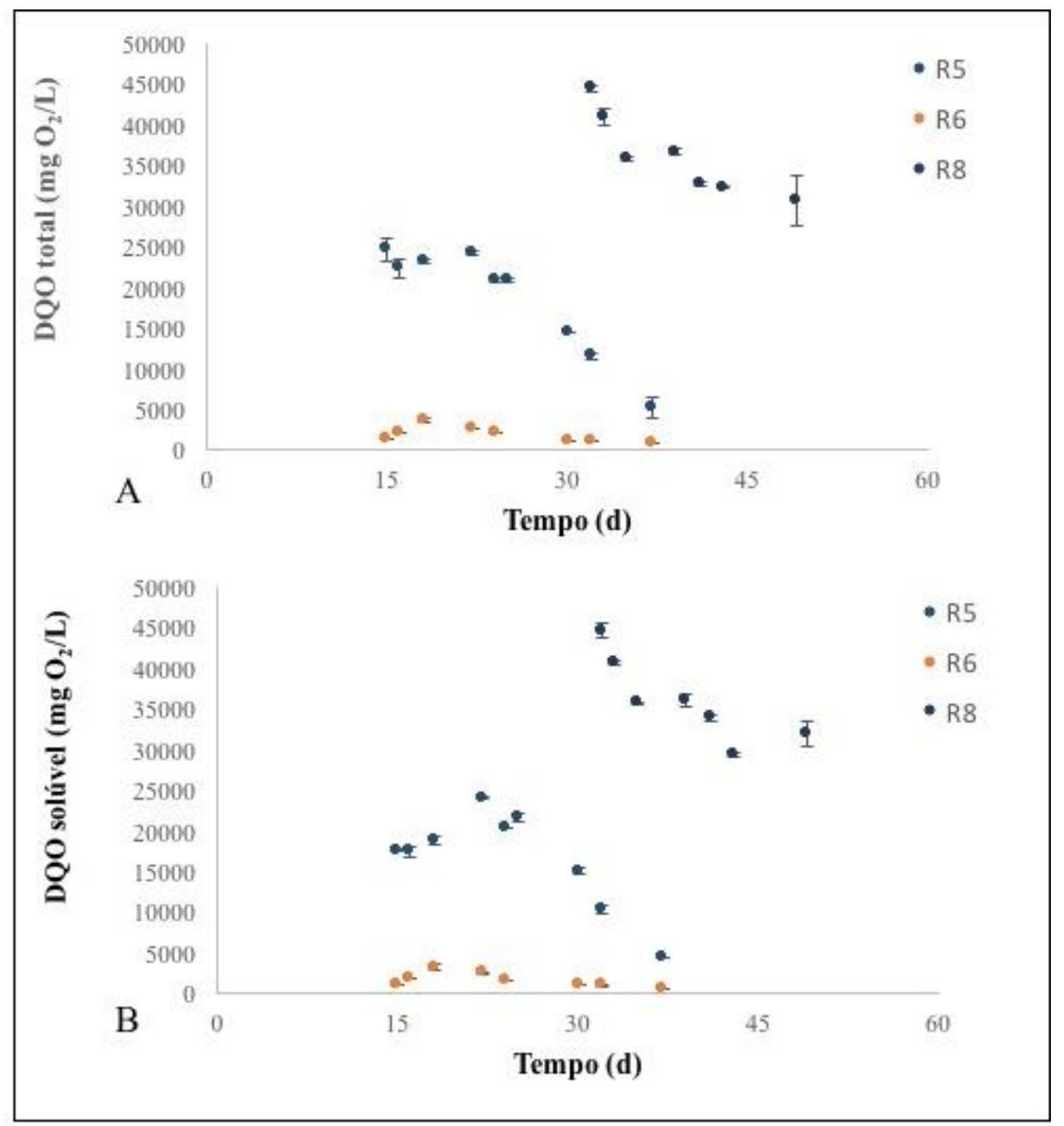

Figura 5.23 - Variação temporal da DQO total (A) e DQO solúvel (B) nos

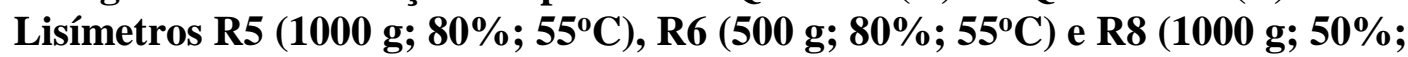
$\left.5^{\circ} \mathrm{C}\right)$ 


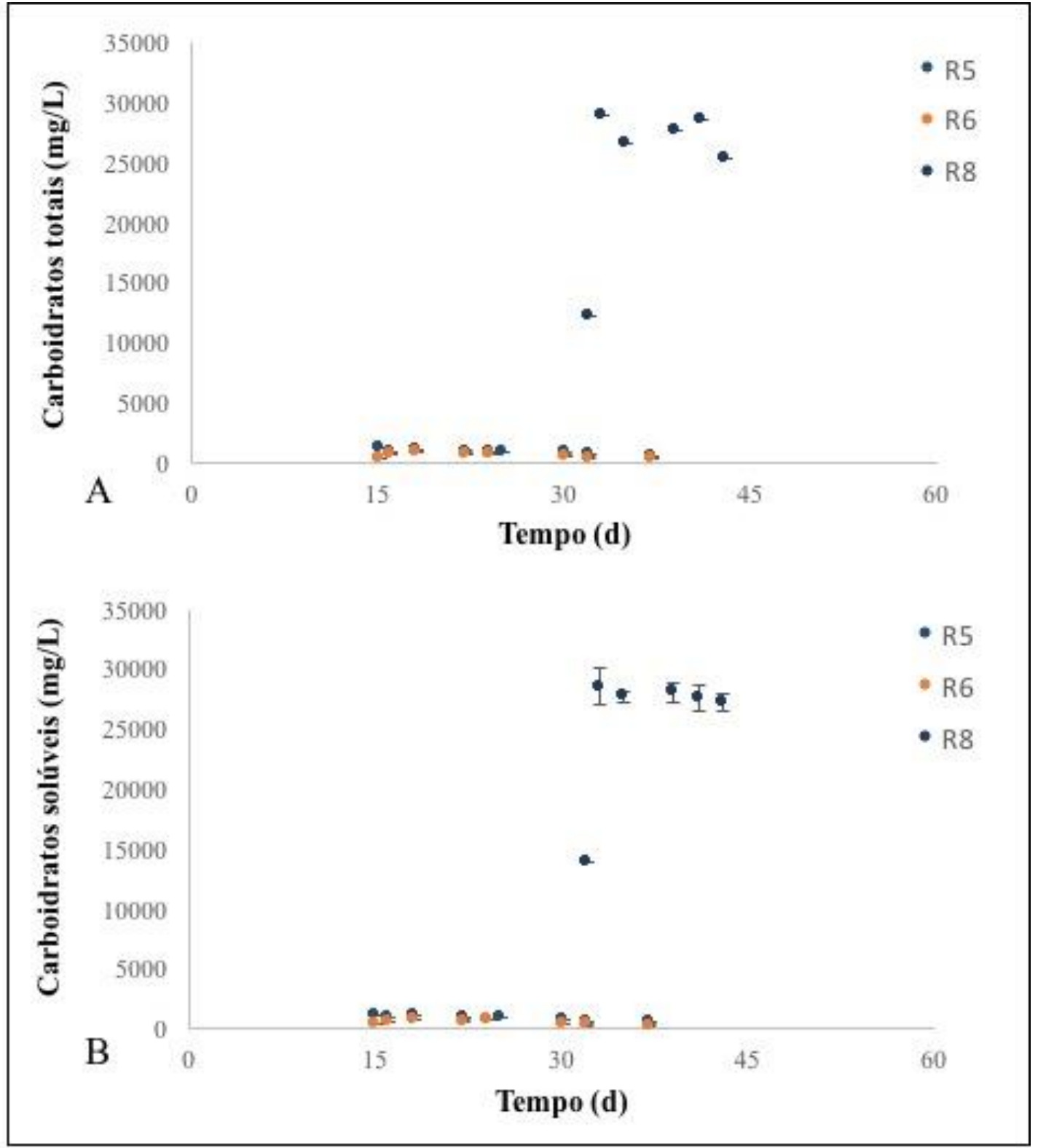

Figura 5.24 - Variação temporal das concentrações de Carboidratos totais (A) e Carboidratos solúveis $(\mathrm{B})$ nos Lisímetros R5 $(1000 \mathrm{~g} ; 80 \%$; 55 $\mathrm{C}), \mathrm{R6}(500 \mathrm{~g}$; $\left.80 \% ; 5^{\circ} \mathrm{C}\right)$ e $\mathrm{R8}\left(1000 \mathrm{~g} ; 50 \% ; 5^{\circ} \mathrm{C}\right)$

Em R9, a DQO efluente foi monitorada a partir do $25^{\circ}$ dia de operação quando houve liberação de volume considerável de percolado (Figura 5.25). Verificou-se DQO solúvel em concentração máxima de $22.500 \pm 710 \mathrm{mg} / \mathrm{L}$, no $25^{\circ}$ dia de operação com redução gradativa a até $2.000 \mathrm{mg} / \mathrm{L}$ ao final da operação (Figura 5.25B). Os elevados valores de DQO solúvel estão relacionados com a detecção de compostos orgânicos solúveis no efluente como os ácidos orgânicos e álcoois e os carboidratos resultantes da hidrólise de papel. Na medida em que se reduziram as concentrações desses compostos 
orgânicos do percolado, também se observou a diminuição da DQO efluente. Concentrações expressivas de carboidratos solúveis foram observadas ao longo do período de análise, com valores de até aproximadamente $7.000 \mathrm{mg} / \mathrm{L}$ (Figura 5.26B). Ao longo do período de operação também foi observada redução gradativa da concentração de carboidratos no percolado de até a $680 \mathrm{mg} / \mathrm{L}$, aproximadamente, no final da operação.

Em R10, a DQO e as concentrações de carboidratos totais foram acompanhadas a partir do $25^{\circ}$ dia de operação quando houve liberação de percolado. A DQO solúvel decresceu gradativamente ao longo do período analisado, com concentração máxima de aproximadamente $18.000 \mathrm{mg} / \mathrm{L}$ no $25^{\circ}$ dia e $1.500 \mathrm{mg} / \mathrm{L}$ nos últimos dias de operação (Figura 5.25B). Em relação aos carboidratos solúveis em meio líquido foram detectados $5.000 \mathrm{mg} / \mathrm{L}$ no início do período analisado (Figura 5.26B). Assim como observado para R9, estas concentrações de carboidratos totais são elevadas em relação àquelas detectadas em outras operações monitoradas (R1-R6). Ao longo do período analisado, verificou-se redução em até $600 \mathrm{mg} / \mathrm{L}$ nos últimos dias de operação (Figura 5.26B). 


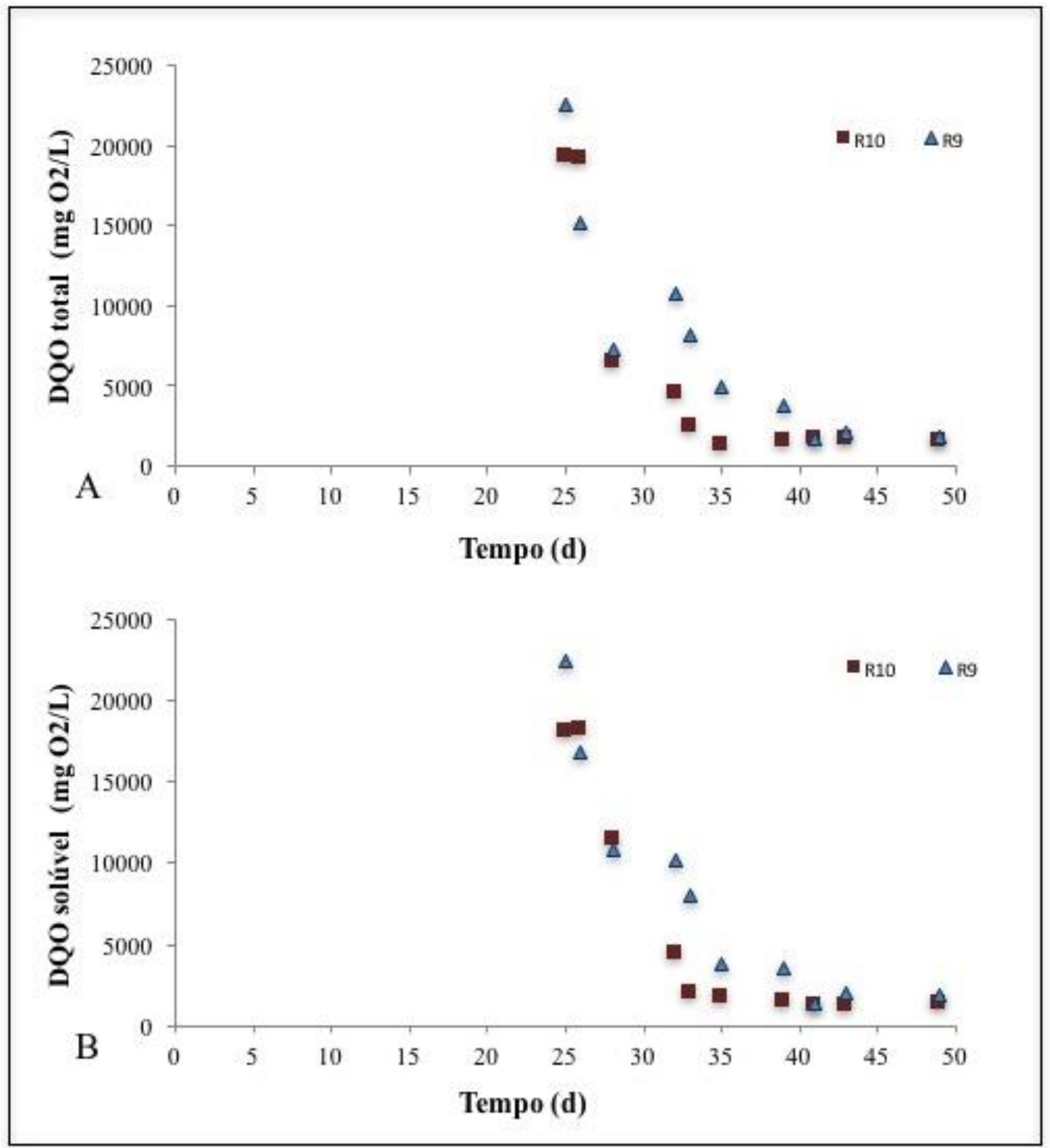

Figura 5.25- Variação temporal da DQO total (A) e DQO solúvel (B) nos Lisímetros R9 $\left(750 \mathrm{~g} ; 65 \% ; 4^{\circ} \mathrm{C}\right)$ e R10 $\left(750 \mathrm{~g} ; 65 \% ; 4^{\circ} \mathrm{C}\right)$ 


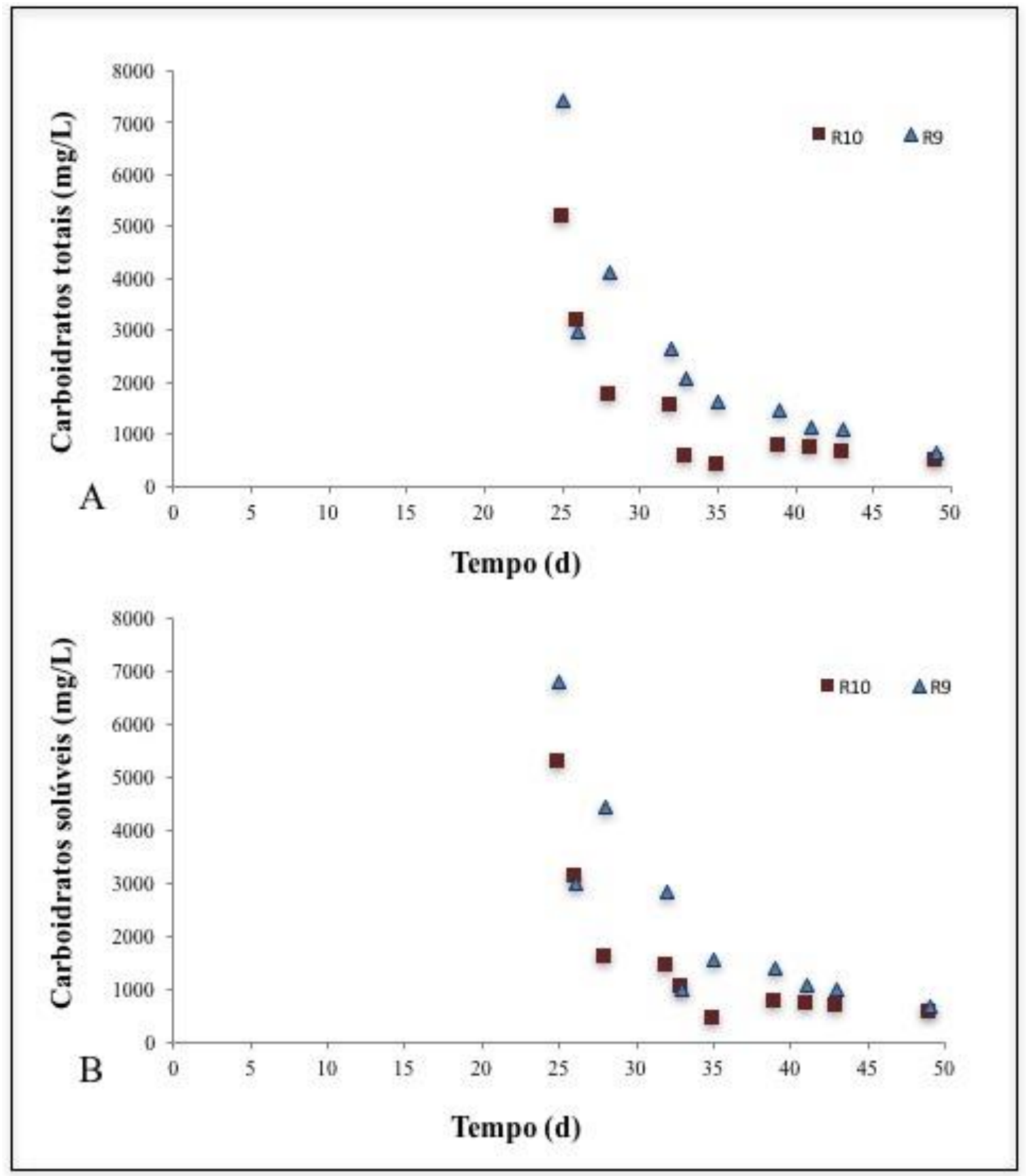

Figura 5.26 - Variação temporal das concentrações de Carboidratos totais (A) e Carboidratos solúveis (B) nos Lisímetros R9 (750 g; 65\%; 45 C) e R10 (750 g; $\left.65 \% ; 45^{\circ} \mathrm{C}\right)$

Analisando-se esses resultados, é possível afirmar que a hidrólise de papel não foi inibida nas condições R8, R9 e R10, já que as concentrações de carboidratos detectadas foram elevadas, inclusive muito superiores àquelas observadas para R1-R6. Entretanto, essa presença expressiva de carboidratos no percolado provavelmente indicou desfavorecimento da atividade fermentativa pela microbiota, já que as concentrações de ácidos orgânicos e álcoois detectadas foram bem reduzidas em relação às operações 
anteriores. Em resumo, a hidrólise de papel parece ter sido menos influenciada pelas condições impostas do que a fermentação dos carboidratos resultantes.

Nas operações dos lisímetros no modelo de Planejamento Experimental, diferentemente das etapas preliminares de operação, houve aumento do $\mathrm{pH}$ efluente em todas as condições estudadas (R1- R10), com média de 6,97 ( $\pm 0,41)$ em relação ao pH do meio de cultura usado para umidificação do papel na montagem do lisímetro, que foi de 5,5. Esse aumento de $\mathrm{pH}$ vai de encontro com o aumento da alcalinidade parcial e total no percolado dos lisímetros (Tabela 5.10).

A hidrólise de papel libera para o meio líquido o composto inorgânico carbonato de cálcio $\left(\mathrm{CaCO}_{3}\right)$, o qual faz parte da composição do papel, somando em torno de $10 \%$ dos sólidos totais (fração inorgânica). Portanto, esse aumento do pH e da alcalinidade pode estar relacionado à presença do $\mathrm{CaCO}_{3}$ no percolado, que permaneceu concentrado devido à disponibilidade reduzida de água em todos os lisímetros. Ao final do período de operação dos reatores observou-se redução gradativa da alcalinidade, provavelmente relacionada à diminuição da hidrólise de papel pela microbiota. Em R6, condição em que foi observada baixa atividade hidrolítica e fermentativa, a alcalinidade foi muito reduzida se comparada às operações anteriores, bem como a DQO e carboidratos totais detectados, ou seja, a atividade hidrolítica foi menor dentre todas as condições estudadas, levando à menor liberação de $\mathrm{CaCO}_{3}$ no efluente (Tabela 5.10).

Tabela 5.10 - Parâmetros físico-químicos de monitoramento do percolado dos lisímetros nas condições R1 a R10

\begin{tabular}{cccccc}
\hline Condição & $\begin{array}{c}\text { pH } \\
\text { efluente* }\end{array}$ & $\begin{array}{c}\text { Alcalinidade } \\
\text { Parcial } \\
(\mathbf{m g} / \mathbf{L})\end{array}$ & $\begin{array}{c}\text { Alcalinidade } \\
\text { Total } \\
(\mathbf{m g} / \mathbf{L})\end{array}$ & $\begin{array}{c}\text { STV final } \\
(\mathbf{g} / \mathbf{L})\end{array}$ & $\begin{array}{c}\text { STV } \\
\text { Pedra } \\
(\mathbf{g} / \mathbf{L})\end{array}$ \\
\hline R1 & 6,95 & 596 & 5.900 & $2,4( \pm 0)$ & 27,6 \\
& $( \pm 0,64)$ & $( \pm 225)$ & $( \pm 1.567)$ & & \\
R2 & 6,58 & 406,81 & $6.891,16$ & $10,12( \pm$ & 14,6 \\
& $( \pm 0,67)$ & $( \pm 129,14)$ & $( \pm 1975.1)$ & $1,11)$ &
\end{tabular}


Continuação

\begin{tabular}{|c|c|c|c|c|c|}
\hline Condição & $\begin{array}{c}\text { pH } \\
\text { efluente* }\end{array}$ & $\begin{array}{c}\text { Alcalinidade } \\
\text { Parcial } \\
(\mathbf{m g} / \mathbf{L})\end{array}$ & $\begin{array}{c}\text { Alcalinidade } \\
\text { Total } \\
(\mathrm{mg} / \mathrm{L})\end{array}$ & $\begin{array}{c}\text { STV final } \\
(\mathrm{g} / \mathrm{L})\end{array}$ & $\begin{array}{c}\text { STV } \\
\text { Pedra } \\
(\mathrm{g} / \mathrm{L})\end{array}$ \\
\hline $\mathrm{R} 4$ & $\begin{array}{c}6,35 \\
( \pm 0,119)\end{array}$ & $\begin{array}{c}427,52 \\
( \pm 203,29)\end{array}$ & $\begin{array}{c}3.330,31 \\
( \pm 1051.33)\end{array}$ & $\begin{array}{c}13,2 \\
( \pm 1,01)\end{array}$ & 16 \\
\hline R5 & $\begin{array}{c}7,25 \\
( \pm 0,28)\end{array}$ & $\begin{array}{c}910,85 \\
( \pm 373,98)\end{array}$ & $\begin{array}{c}5.164,63( \pm \\
3.308,39)\end{array}$ & $\begin{array}{c}4,7 \\
( \pm 0,14)\end{array}$ & 55,14 \\
\hline R6 & $\begin{array}{c}7,25 \\
( \pm 0,28)\end{array}$ & $\begin{array}{c}380 \\
( \pm 122)\end{array}$ & $600( \pm 237)$ & $\begin{array}{c}1,4 \\
( \pm 0,35)\end{array}$ & 20 \\
\hline $\mathrm{R} 7$ & - & - & - & - & - \\
\hline $\mathrm{R} 8$ & $\begin{array}{c}7,28 \\
( \pm 1,24)\end{array}$ & - & - & $25,83^{*}$ & $\begin{array}{c}2,0 \\
( \pm 0,4)\end{array}$ \\
\hline R9 & $\begin{array}{c}6,82 \\
( \pm 1,24)\end{array}$ & $\begin{array}{c}392,68 \\
( \pm 48,92)\end{array}$ & $\begin{array}{c}841,62 \\
( \pm 397,23)\end{array}$ & 2 & $\begin{array}{c}1,614 \\
( \pm 0,02)\end{array}$ \\
\hline $\mathrm{R} 10$ & $\begin{array}{c}7,31 \\
( \pm 0,8)\end{array}$ & $\begin{array}{c}410,3 \\
( \pm 37,39)\end{array}$ & $\begin{array}{c}776,5 \\
( \pm 380,7)\end{array}$ & 2 & $\begin{array}{c}1,633 \\
( \pm 0,047)\end{array}$ \\
\hline
\end{tabular}

Em relação ao STV, em todas as condições verificou-se aumento da concentração ao longo do período de operação. Em R1, o valor de STV no percolado, ao final da operação foi de 2,4 $\pm 0 \mathrm{~g} / \mathrm{L}$. Ao longo da operação, verificou-se variação de STV de 6,56 $( \pm 2,42)$ a $7,73( \pm 0,1) \mathrm{g} / \mathrm{L}$, o que pode significar lavagem dos microrganismos (STV) presentes no lisímetro, levando à diminuição da atividade fermentativa, com consequente redução das concentrações de compostos orgânicos solúveis no percolado.

A concentração de STV detectada nas pedras ao final da operação de R1 foi de 27,6 g/L (Tabela 5.10). Em R2, a concentração de STV ao longo da operação foi de 10,12 $\pm 1,11 \mathrm{~g} / \mathrm{L}$ (Tabela 5.10), enquanto, aquela detectada nas pedras ao final da operação foi 
de 14,6 g/L (Tabela 5.10). Em R3, foi possível analisar apenas ao final do período de operação a massa de STV aderida às pedras adicionadas abaixo do leito de substrato (papel) no reator. Neste reator, cuja atividade fermentativa foi muito reduzida, a concentração de STV nas pedras foi a menor detectada dentre todas as operações (R1R4) e foi de 9,7 g/L. Em R4, verificou-se que a concentração final de STV no percolado aumentou para 13,2 \pm 1,01 g/L (Tabela 5.10), ou seja, as condições operacionais foram favoráveis para o crescimento de micro-organismos, porém não suficiente para bom desempenho do tratamento do papel e produção de energia. A concentração de STV detectada nas pedras ao final da operação foi de 16,0 g/L (Tabela 5.10).

Pela análise dos resultados de STV em R5, pôde-se também concluir que o crescimento dos micro-organismos foi favorecido quando incubados em temperatura termofílica (R5), em comparação com a temperatura mesofílica (R1 - R4). A concentração média de STV ao longo da operação foi de 11,82 \pm 0,4 g/L, ou seja, maior do que aquelas observadas para R1 e R2. Além disso, a concentração de STV aderida às pedras também foi maior para R5, com 55,14 ( \pm 0,76) g/L (Tabela 5.10), em conformidade com os outros resultados obtidos para esse lisímetro, em que se verificou, dentre as condições estudadas, maior atividade fermentativa do inóculo utilizado.

Já em R6, verificou-se que os valores de STV também não favoreceram o crescimento e a atividade fermentativa da biomassa, apresentando pouco aumento de STV ao final da operação, 1,4 g/L ( \pm 0,35) (Tabela 5.10). Ao longo da operação verificouse que as concentrações de STV variaram de 0,04 a 2,28 \pm 0,35 g/L, ou seja, bem abaixo daquelas observadas para R5. Ao final da operação de R8, a concentração de STV detectada foi de 25,83 g/L (Tabela 5.10), entretanto, essa concentração deveu-se provavelmente à elevada concentração de carboidratos totais solúveis na amostra do que efetivamente de biomassa microbiana. Após o período de secagem em estufa a $105^{\circ} \mathrm{C}$, durante a análise de STV, pôde-se observar massa expressiva de carboidratos na cápsula de porcelana. Ao final da operação, a concentração de STV detectada nas pedras foi de aproximadamente 2,0 $\pm 0,4 \mathrm{~g} / \mathrm{L}$ (Tabela 5.10).

Em relação aos sólidos totais voláteis em R9, foi detectada $10,8 \mathrm{~g} / \mathrm{L}$ no $26^{\circ}$ dia de operação, porém foi reduzida gradativamente para 7,2 g/L, 3,35 g/L a $2 \mathrm{~g} / \mathrm{L}$ ao final da operação (Tabela 5.10). Assim como observado nas operações anteriores, a diminuição gradativa de STV no percolado pode significar lavagem dos micro-organismos presentes no sistema, levando à minimização da atividade fermentativa no lisímetro, com consequente redução das concentrações de compostos orgânicos solúveis no percolado. 
A concentração de STV detectada nas pedras ao final da operação foi de 1,633 \pm 0,047 g/L ) (Tabela 5.10). Em relação ao STV efluente em R10, houve aumento da concentração ao longo da operação para 8 g/L (Tabela 5.10), com posterior redução desta concentração à $2 \mathrm{~g} / \mathrm{L}$ no final da operação. A concentração de STV detectada nas pedras ao final da operação foi de 1,633 \pm 0,047 g/L (Tabela 5.10).

Em todos os lisímetros, a diminuição da concentração de STV ao final da operação possivelmente foi devido a liberação no percolado dos micro-organismos aderidos ao papel durante as aspersões sequenciais de meio de cultura durante o período de incubação.

\subsubsection{Consumo de Papel nos Lisímetros}

Para quantificar-se a massa de papel total removida ao longo de cada operação, considerou-se a massa seca de papel adicionada na montagem do lisímetro e a massa seca de papel ao final da operação, desconsiderando o peso referente ao teor de umidade, possibilitando conhecer a massa aproximada de papel que foi hidrolisada pela microbiota usada como inóculo nos lisímetros. Os resultados de massa de papel removida (g) e percentual de remoção de papel estão listados na Tabela 5.11.

Tabela 5.11 - Percentual de remoção de papel nas condições estudadas

\begin{tabular}{|c|c|c|c|c|c|}
\hline Lisímetro & $\begin{array}{c}\text { Massa } \\
\text { seca } \\
\text { inicial de } \\
\text { papel } \\
\text { (g) }\end{array}$ & $\begin{array}{c}\text { Massa } \\
\text { seca final } \\
\text { de papel } \\
\text { (g) }\end{array}$ & $\begin{array}{c}\text { Massa de } \\
\text { Papel } \\
\text { Removida } \\
\text { (g) }\end{array}$ & $\begin{array}{c}\text { Massa de } \\
\text { papel } \\
\text { retirada } \\
\text { para } \\
\text { análises } \\
\text { (g) }\end{array}$ & $\begin{array}{c}\text { Percentual de } \\
\text { Remoção de } \\
\text { Papel (\%) }\end{array}$ \\
\hline R1 & 969 & 871 & 84,5 & 13,5 & 8,45 \\
\hline $\mathrm{R} 2$ & 507 & 434 & 54 & 19 & 10,8 \\
\hline R3 & 499 & 475 & 11 & 13 & 2,2 \\
\hline $\mathrm{R} 4$ & - & - & - & - & 1,1 \\
\hline R5 & 980 & 846 & 127 & 7.4 & 12,7 \\
\hline R6 & 489 & 441 & 41 & 7,35 & 8,1 \\
\hline R7 & 468 & 457 & 11 & - & 2,2 \\
\hline $\mathrm{R} 8$ & 928 & 890 & 28 & 10,6 & 2,8 \\
\hline R9 & 727 & 695 & 22 & 10 & 2,95 \\
\hline $\mathrm{R} 10$ & 722 & 680 & 28 & 14 & 3,8 \\
\hline
\end{tabular}


A massa de papel úmido no início da operação de R1 foi de 2.076,5 g, com teor de umidade de $78 \%$, enquanto que a massa de substrato ao final da operação foi de $2.614,88 \mathrm{~g}$, com teor de umidade de $100 \%$. Portanto, a massa seca de papel no início e final da operação foram de $969 \mathrm{~g}$ e $871 \mathrm{~g}$, respectivamente, e a massa de papel seca retirada ao longo da operação foi de 13,5 g. Considerando esses valores, a redução de massa de papel entre o início e final da operação foi de aproximadamente 84,5 g. Esse valor correspondeu à $8,45 \%$ da massa seca de papel adicionada no início da operação de R1.

Em R2, a massa de papel úmido no início da operação foi de $1.088 \mathrm{~g}$, com teor de umidade de $85 \%$, enquanto que a massa de substrato ao final da operação foi de $1.304 \mathrm{~g}$, com teor de umidade de $100 \%$. Portanto, a massa seca de papel no início e final da operação foram de $507 \mathrm{~g}$ e $434 \mathrm{~g}$, respectivamente, e a massa de papel seca retirada ao longo da operação foi de $19 \mathrm{~g}$. Considerando esses valores, a redução de massa de papel entre o início e o final da operação foi de aproximadamente $54 \mathrm{~g}$. Esse valor correspondeu a 10,8\% da massa seca de papel adicionada no início da operação em R2.

A massa de papel úmido no início da operação de R3 foi de $734 \mathrm{~g}$, com teor de umidade de 48\%, enquanto que a massa de substrato ao final da operação foi de $1018 \mathrm{~g}$, com teor de umidade de $80,5 \%$. Portanto, a massa seca de papel no início e final da operação foram de $499 \mathrm{~g}$ e $475 \mathrm{~g}$, respectivamente, e a massa de papel seca retirada ao longo da operação foi de $13 \mathrm{~g}$. Considerando esses valores, a redução de massa de papel entre o início e o final da operação foi de aproximadamente $11 \mathrm{~g}$. Esse valor correspondeu a 2,2\% da massa seca de papel adicionada no início da operação em R3.

Na condição R4, o percentual de redução da massa seca de papel entre o ínicio e final da operação foi de $1,1 \%$, o que significa $11 \mathrm{~g}$. Os carboidratos em meio líquido foram indicativo da atividade hidrolítica de papel usado como substrato, e os teores reduzidos de ácidos orgânicos foram sinal de baixa atividade fermentativa. As condições operacionais aplicadas em R4 não inibiram o crescimento de populações celulolíticas, porém podem ter inibido a fermentação acidogênica anaeróbia.

Em R5, a massa de papel úmido no início da operação foi de $2.101,3 \mathrm{~g}$, com teor de umidade de $81 \%$, enquanto que a massa de substrato ao final da operação foi de 2.539 g, com teor de umidade de $100 \%$. Portanto, a massa seca de papel no início e final da operação foram de $980 \mathrm{~g}$ e $846 \mathrm{~g}$, respectivamente, e a massa de papel seca retirada ao longo da operação foi de 7,4 g. Considerando esses valores, a redução de massa de papel 
entre o início e o final da operação foi de aproximadamente $127 \mathrm{~g}$, o que corresponde a $12,7 \%$ do total de papel adicionado.

A massa de papel úmido no início da operação de R6 foi de 1048 g, com teor de umidade de $82 \%$, enquanto que a massa de substrato ao final da operação foi de $1324 \mathrm{~g}$, com teor de umidade de $100 \%$. Portanto, a massa seca de papel no início e final da operação foram de $489 \mathrm{~g}$ e $441 \mathrm{~g}$, respectivamente, e a massa de papel seca retirada ao longo da operação foi de 7,35 g. Considerando esses valores, a redução de massa de papel entre o início e o final da operação foi de aproximadamente $41 \mathrm{~g}$, o que corresponde a $8,1 \%$ do total de papel adicionado.

Em R7, A massa de papel úmido no início da operação foi de $739 \mathrm{~g}$, com teor de umidade de 55\%, enquanto que a massa de substrato ao final da operação foi de $1162 \mathrm{~g}$, com teor de umidade de 90,97\%. Portanto, a massa seca de papel no início e final da operação foram de $468 \mathrm{~g}$ e $457 \mathrm{~g}$, respectivamente. Considerando esses valores, a redução de massa de papel entre o início e o final da operação foi de aproximadamente $11 \mathrm{~g}$. Esse valor corresponde a 2,2\% da massa seca de papel adicionada no início da operação em R7.

A massa de papel úmido no início da operação de R8 foi de 1.498 g, com teor de umidade inicial de $56,7 \%$, enquanto que a massa de substrato ao final da operação foi de $2.328 \mathrm{~g}$, com teor de umidade de 92,5\%. Considerando-se esses valores, somados à massa de papel seca retirada ao longo da operação $(10,6$ g), a redução da massa de papel entre o início e fim da operação foi de aproximadamente $28 \mathrm{~g}$. Esse valor corresponde a 2,8\% da massa de papel seca adicionada no início da operação em R8. Essa porcentagem de consumo é semelhante àquelas observadas para R3 e R7, ou seja, menores que àquelas observadas nos reatores R1, R2, R5 e R6.

A massa de papel úmido adicionado no ínicio da operação de R9 foi de $1.302 \mathrm{~g}$, com teor de umidade de $66,26 \%$, e a massa final foi de $2.328 \mathrm{~g}$, com umidade a $95 \%$. Assim, a massa seca no início e ao final da operação foi de 727 g e 695 g, respectivamente, e a massa de papel seca retirada ao longo da operação foi de $10 \mathrm{~g}$. Portanto, a redução foi de aproximadamente $22 \mathrm{~g}$, o que correspondeu a 2,95\%. Já em R10, a massa de papel úmido adicionada no lisímetro foi de $1.302 \mathrm{~g}$, com teor de umidade de 66,82 \%, e a massa de substrato final foi de 1.888,5 g, com teor de umidade de $96 \%$. Portanto, a massa seca de papel no início e final da operação foram de $722 \mathrm{~g}$ e $680 \mathrm{~g}$, respectivamente, e a massa de papel seca retirada ao longo da operação foi de $14 \mathrm{~g}$. A redução de massa de papel 
entre o início e o final da operação foi de aproximadamente $28 \mathrm{~g}$, o que correspondeu a $3,8 \%$ do total de papel adicionado.

As porcentagens de consumo de papel nos lisímetros R9 e R10 foram reduzidas e muito semelhantes. Aparentemente, a temperatura intermediária de $45^{\circ} \mathrm{C}$, tanto quanto o teor de umidade de $65 \%$ nos reatores R9 e R10 não foram satisfatórias para a hidrólise de papel por parte da microbiota utilizada nesta configuração de reator.

\subsection{Análise Comparativa entre as condições de operação do lisímetro propostas no planejamento experimental}

A Tabela 5.12 resume alguns resultados de parâmetros selecionados para a análise do desempenho de cada condição dos lisímetro.

Tabela 5.12 - Análise comparativa dos parâmetros analisados nos lisímetros R1-R10

\begin{tabular}{|c|c|c|c|c|c|c|c|c|c|c|}
\hline Parâmetros & $\mathbf{R 1}$ & $\mathbf{R 2}$ & $\mathbf{R 3}$ & R4 & R5 & R6 & R7 & $\mathbf{R 8}$ & R9 & R10 \\
\hline Massa de Papel (g) & 1000 & 500 & 500 & 1000 & 1000 & 500 & 500 & 1000 & 750 & 750 \\
\hline Temperatura $\left({ }^{\circ} \mathrm{C}\right)$ & 35 & 35 & 35 & 35 & 55 & 55 & 55 & 55 & 45 & 45 \\
\hline $\begin{array}{l}\text { Teor umidade } \\
\text { Inicial }(\%)\end{array}$ & 78 & 85 & 48 & 52 & 81 & 82 & 55 & 56,7 & 66 & 67 \\
\hline $\begin{array}{l}\text { Quantidade máxima } \\
\mathrm{H}_{2}(\mathrm{mmol})\end{array}$ & 25 & 35 & $\begin{array}{l}< \\
\text { L.D. }\end{array}$ & $\begin{array}{l}< \\
\text { L.D. }\end{array}$ & 3,14 & $\begin{array}{l}< \\
\text { L.D. }\end{array}$ & $\begin{array}{l}< \\
\text { L.D. }\end{array}$ & $\begin{array}{c}< \\
\text { L.D. }\end{array}$ & $\begin{array}{l}< \\
\text { L.D. }\end{array}$ & < L.D. \\
\hline $\begin{array}{l}\text { Potencial Máximo } \\
\text { de Produção } \mathrm{H}_{2} \\
\text { (mmol) }\end{array}$ & 30,72 & 35 & - & - & - & - & - & - & - & - \\
\hline $\begin{array}{l}\text { Velocidade máxima } \\
\text { de Produçãa } \mathrm{H}_{2} \\
(\mathrm{mmol} / \mathrm{d})\end{array}$ & 1,02 & 2,26 & - & - & - & - & - & - & - & - \\
\hline Fase lag $(\mathrm{h})$ & 2,35 & 2,31 & - & - & - & - & - & - & - & - \\
\hline $\begin{array}{l}\text { Quantidade máxima } \\
\qquad \mathrm{CO}_{2}(\mathrm{mmol})\end{array}$ & 92 & 93 & 9,85 & 23,8 & 53,62 & 56,16 & 6,5 & 7,0 & 24,4 & 17 \\
\hline
\end{tabular}




\begin{tabular}{|c|c|c|c|c|c|c|c|c|c|c|}
\hline $\begin{array}{l}\text { Compostos } \\
\text { orgânicos solúveis } \\
(\mathrm{mg} / \mathrm{L})^{*}\end{array}$ & & & & & & & & & & \\
\hline Ácido acético & $\begin{array}{c}21.50 \\
0\end{array}$ & $\begin{array}{c}17.00 \\
0\end{array}$ & - & 158 & $\begin{array}{c}10.00 \\
0\end{array}$ & 780 & - & 450 & 455 & 970 \\
\hline Ácido butírico & 4.500 & 2.800 & - & 1154 & 4.000 & 590 & - & 90 & 775 & 460 \\
\hline & & & & & & & & & & Continua \\
\hline \multicolumn{11}{|l|}{ Continuação } \\
\hline Parâmetros & R1 & $\mathbf{R 2}$ & $\mathbf{R 3}$ & $\mathbf{R 4}$ & R5 & R6 & R7 & $\mathbf{R 8}$ & $\mathbf{R 9}$ & R10 \\
\hline Ácido propiônico & 440 & 800 & - & 0 & 4.800 & 160 & - & 20 & 380 & 650 \\
\hline Etanol & 1.570 & 1.800 & - & 412 & 2.300 & 42 & - & 23 & 56 & 40 \\
\hline Metanol & $\begin{array}{c}< \\
\text { L.D. }\end{array}$ & $\begin{array}{l}< \\
\text { L.D. }\end{array}$ & - & 70 & 5.600 & 1.094 & - & 95 & 46 & 50 \\
\hline$n$-butanol & 228 & 240 & $\begin{array}{c}< \\
\text { L.D. }\end{array}$ & $\begin{array}{c}< \\
\text { L.D. }\end{array}$ & 56 & $\begin{array}{c}< \\
\text { L.D. }\end{array}$ & $\begin{array}{c}< \\
\text { L.D. }\end{array}$ & $\begin{array}{c}< \\
\text { L.D. }\end{array}$ & $\begin{array}{c}< \\
\text { L.D. }\end{array}$ & < L.D. \\
\hline Consumo Papel (\%) & 8,45 & 10,8 & 2,2 & 2,01 & 12,7 & 8,2 & 2,2 & 2,8 & 2,95 & 3,8 \\
\hline Consumo Papel (g) & 84,5 & 54 & 11 & 20 & 127 & 41 & 11 & 28 & 22 & 28 \\
\hline STV (g/L) ** & 7,73 & 10,12 & - & 13,4 & 11,82 & 2,28 & - & 25,83 & 10,8 & 8 \\
\hline $\begin{array}{l}\text { pH (média } \\
\text { operação) }\end{array}$ & 6,95 & 6,58 & - & 6,35 & 7,25 & 7,93 & - & 7,28 & 6,82 & 7,31 \\
\hline
\end{tabular}

* Concentrações Máximas

** Concentrações máximas detectadas ao longo do período de operação

Em todas as condições estudadas não houve produção de metano detectável pelo método cromatográfico. Todos os metabolismos observados durante as operações, por 
meio da análise do biogás e do percolado (efluente), foram hidrolíticos e/ou fermentativos, com geração de hidrogênio, gás carbônico, ácidos orgânicos voláteis e álcoois. O enriquecimento do fluido de rúmen, portanto, foi eficaz para minimizar/ inibir as arqueias metanogênicas no consórcio, e favorecer as populações hidrolíticas e fermentativas. A ausência de sais de sulfato no meio de cultura e no substrato resultou em ausência de sulfeto de hidrogênio no biogás.

A presença de metabólitos e produtos finais da fermentação no percolado de todas as operações realizadas, com exceção de R3 e R7, permitem concluir a obtenção de atividade celulolítica e fermentativa para o consórcio microbiano sob todas as condições impostas. O desempenho de hidrólise e fermentação de papel foi observado em diferentes graus de acordo com as variáveis impostas em cada condição.

A temperatura de incubação dos lisímetros foi, provavelmente, o principal fator de influência nos metabolismos fermentativos. Verificou-se para a fermentação mesofílica produção de hidrogênio e ácidos orgânicos, seguida de homoacetogênese, gerando elevadas concentrações de ácido acético. Já em condição termofílica observouse, principalmente, geração de álcoois (etanol e metanol), com reduzida produção de hidrogênio observada em R5 apenas. A temperatura intermediária de $45^{\circ} \mathrm{C}$ não foi favorável ao crescimento da microbiota nos lisímetros, pois foi verificado baixo consumo de substrato, ausência de hidrogênio no biogás e concentrações reduzidas de metabólitos solúveis no efluente. $\mathrm{O}$ fator temperatura $45^{\circ} \mathrm{C}$ pode ter sido agravado pelo teor de umidade inicial de 65\% do papel (substrato) quanto à atividade atenuada de hidrólise papel e produção de energia em R9 e R10.

Em relação à umidade, verificou-se para todas as condições com teor de umidade de 50 e $65 \%$, consumo de papel reduzido ao longo da operação, em comparação com os lisímetros que continham teor de umidade inicial de $80 \%$. Por meio de análise geral dos parâmetros avaliados, principalmente da porcentagem de consumo de papel ao longo das operações, verificou-se que o teor de umidade inicial de $80 \%$ foi determinante para o estabelecimento da microbiota nos lisímetros. De acordo com os resultados, pode-se afirmar que a disponibilidade de água e sais minerais esteve relacionada ao desempenho celulolítico e fermentativo da biomassa microbiana, e o teor reduzido de água acarretou baixo desempenho do lisímetro.

Por fim, pode-se inferir que a massa inicial de substrato (papel) não foi um fator de influência na atividade microbiana de hidrólise e fermentação do papel. Pôde-se 
observar porcentagens de consumo de papel semelhantes para os reatores R1, R2; R5 e R6, os quais foram operados com 500 e $1000 \mathrm{~g}$ de papel, respectivamente.

\subsection{Caracterização Microbiana}

\subsubsection{PCR/DGGE}

Por meio da análise de DGGE, que viabiliza a comparação da estrutura da comunidade microbiana entre amostras de micro-organismos, pretendeu-se avaliar a influência dos três principais fatores operacionais estudados na comunidade microbiana dos lisímetros. Tais fatores foram os seguintes: temperatura $\left(35 \mathrm{a} 55^{\circ} \mathrm{C}\right)$, teor de umidade do substrato (50 a 80\%) e massa de substrato adicionada aos lisímetros (500 a 1000 g). O dendrograma, apresentado na Figura 5.27, foi confeccionado pelo método de agrupamento UPGMA e coeficiente de similaridade de Pearson, a partir do padrão de bandas do DGGE com iniciadores para o Domínio Bacteria.

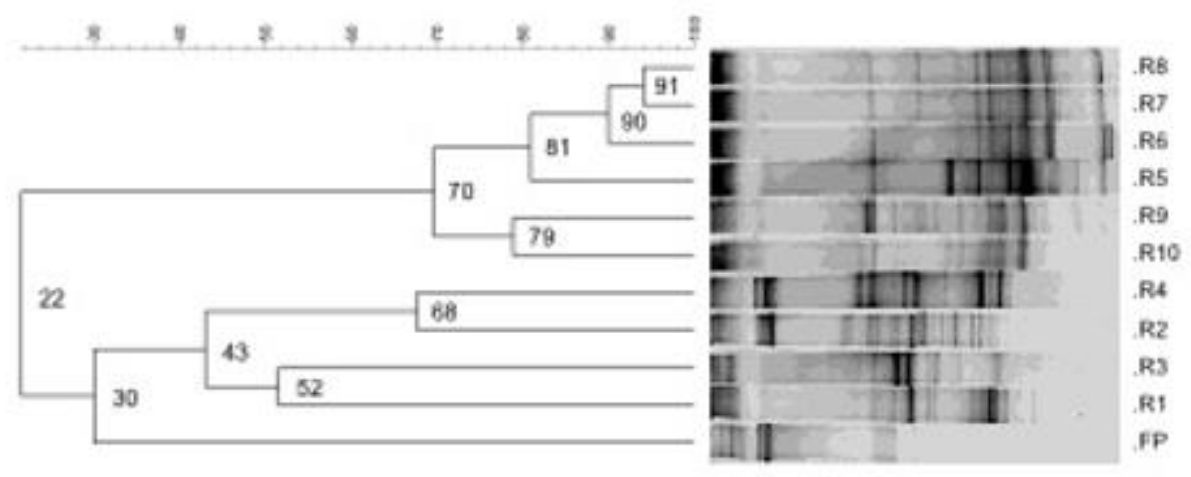

Figura 5.27 - Dendrograma baseado no coeficiente de similaridade de Pearson (UPGMA) a partir do padrão de bandas do DGGE do gene RNAr 16S para o Domínio Bacteria. Legenda: F.P.: fluido de rúmen enriquecido; $\mathrm{R} 1: 1000 \mathrm{~g}, 80 \%, 3^{\circ} \mathrm{C}$; R2: $500 \mathrm{~g}, 80 \%, 3^{\circ} \mathrm{C}$; R3: $500 \mathrm{~g}, 50 \%, 3^{\circ} \mathrm{C}$; R4: $1000 \mathrm{~g}, 50 \% 3^{\circ} \mathrm{C}$; R5: $1000 \mathrm{~g}, 80 \%$, $5^{\circ} \mathrm{C}$; R6: $500 \mathrm{~g}, 80 \%, 5^{\circ} \mathrm{C}$, $\mathrm{R7}: 500 \mathrm{~g}, 50 \%, 5^{\circ} \mathrm{C}$; R8: $1000 \mathrm{~g}$, 50\%, $5^{\circ} \mathrm{C}$,; R9: $750 \mathrm{~g}, 65 \%, 4^{\circ} \mathrm{C}$; R10: $750 \mathrm{~g}, 65 \%, 4^{\circ} \mathrm{C}$

Verificou-se que as populações de bactérias dos lisímetros das operações mesofílicas foram similares em $30 \%$ aquelas do fluido de rúmen enriquecido (F.P.), ao 
passo que para os reatores operados em temperaturas mais altas verificou-se similaridade de $22 \%$ à F.P (Figura 5.27).

Dentre os lisímetros, verificou-se para as populações de bactérias de R1 a R4, operados a $35^{\circ} \mathrm{C}, 43$ a $68 \%$ de similaridade, enquanto para aquelas de R9 e R10, operados a $45^{\circ} \mathrm{C}$, verificou-se $79 \%$ e para as populações de $\mathrm{R} 5$ a R8, operados a $55^{\circ} \mathrm{C}, 81$ a $91 \%$. Analisando-se os dados, verificou-se que a temperatura de operação foi o principal fator influência no estabelecimento de populações microbianas após o período de operação dos lisímetros, sob as diferentes condições estudadas, sendo todos inoculados com fluido de rúmen após enriquecimento seletivo.

A etapa de enriquecimento do fluido de rúmen in natura para favorecimento das populações celulolíticas e fermentativas e inibição das arqueias metanogênicas e a etapa de reativação do fluido de rúmen enriquecido foram realizadas sob temperatura mesofílica de $35^{\circ} \mathrm{C}$, e dessa forma, esperava-se obter maior porcentagem de similaridade entre a amostra F.P. e as amostras dos lisímetros R1 a R4, a qual foi de $30 \%$. Isso significa que, ainda que cultivados sob a mesma temperatura, houve variação considerável na estrutura das populações de bactérias da biomassa dos lisímetros, podendo estar relacionada com a fermentação em estado semissólido (não submersa) e menor controle da anaerobiose nestes reatores. Verificou-se similaridade de $22 \%$ entre as populações de bactérias do F.P. e a biomassa dos lisímetros R5 a R8, operados a $55^{\circ} \mathrm{C}$, e de R9 e R10, operados a $45^{\circ} \mathrm{C}$.

O aumento da temperatura de incubação de $35^{\circ} \mathrm{C}$ para $45-55^{\circ} \mathrm{C}$, provavelmente favoreceu populações de bactérias semelhantes na biomassa dos lisímetros R5 a R10, já que foi observada similaridade de $70 \%$ entre eles.

Porém, para a mesma temperatura, aparentemente o fator umidade não influenciou nas populações de bactérias dos lisímetros. Por exemplo, sob temperatura de $35^{\circ} \mathrm{C}$, verificou-se para R1 e R2, operados com $80 \%$ de umidade, e para os lisímetros R3 e R4, operados com 50\% de umidade, a mesma similaridade entre si, ou seja, de $43 \%$. Neste caso, R1 e R3, e R2 e R4 foram agrupados com $68 \%$ e 52\% de similaridade, respectivamente (Figura 5.27).

Já para a temperatura termofílica, os lisímetros R6, R7 e R8 foram agrupados com similaridade acima de $90 \%$. Dentre todos os lisímetros operados a $55^{\circ} \mathrm{C}$, o único em que foi observado hidrogênio no headspace foi em R5, cuja similaridade observada foi menor (81\%) em relação aos outros 3 , ou seja, provavelmente as populações produtoras de 
hidrogênio não foram favorecidas nos lisímetros R6, R7, R8, nos quais a atividade metabólica foi reduzida.

Levando-se em conta a massa de papel adicionada, este fator não foi determinante para selecionar as populações de bactérias na comunidade dos lisímetros operados com a mesma massa, pois sob temperatura mesofílica, a similaridade entre R1 e R4, contendo $1000 \mathrm{~g}$, e de R2 e R3, contendo $500 \mathrm{~g}$, foi a mesma de $43 \%$. Sob $45^{\circ} \mathrm{C}$, observou-se $79 \%$ de similaridade entre as populações de bactérias, mesmo se tratando de réplicas de reatores, e, sob temperatura termofílica, observou-se maior similaridade entre R6, R7 e R8, contendo 500 e 1000 g, do que entre R5 e R8, amsbos contendo 1000 g, cujas porcentagens foram de $90 \%$ e $81 \%$, respectivamente (Figura 5.27).

\subsection{Diversidade Microbiana}

Pôde-se inferir que a temperatura foi a principal variável de influência nos metabolismos bioquímicos de fermentação do papel, portanto foi escolhida uma amostra para cada temperatura estudada. O lisímetro R2 foi selecionado, uma vez que sob tais condições verificou-se a maior produção de hidrogênio dentre as operações mesofílicas. Já dentre as operações termofílicas, verificou-se melhor desempenho fermentativo nas condições de R5. Ambos os reatores foram operados sob umidade inicial do substrato de $80 \%$. O R9 foi selecionado para se avaliar a biomassa microbiana sob condição a $45{ }^{\circ} \mathrm{C}$, comparando-a com as outras condições de temperatura e umidade.

Amostras de micro-organismos do fluido de rúmen in natura (F.N.), fluido de rúmen enriquecido (F.P.), biomassa microbiana do lisímetro R2 $\left(35^{\circ} \mathrm{C} ; 500 \mathrm{~g} ; 80 \%\right)$, lisímetro R5 (55 $\left.{ }^{\circ} \mathrm{C} ; 1000 \mathrm{~g} ; 80 \%\right)$ e lisímetro R9 (45 $\left.{ }^{\circ} \mathrm{C} ; 750 \mathrm{~g} ; 65 \%\right)$, ou seja, em 5 amostras procedeu-se o sequenciamento massivo via plataforma Illumina (Miseq). Foi obtido o total de 452.402 sequências do gene RNAr 16S, sendo o número de sequência para cada amostra de 104.194 para F.N., 86.269 para F.P., 27.133 para R2, 90.069 para R5 e 144.737 para R9 (Tabela 5.13).

Durante o processamento foi realizada uma filtragem das sequências de baixa qualidade e sequência de adaptadores, usando como cutoff bases com qualidade inferior a 24 QScore (Q>24). Após essa filtragem, sequências com comprimento inferior a 65 pares de base foram removidas. As sequências obtidas, após o processamento, continham número médio de pares de base de $275 \pm 9,90$. 
As sequências com similaridade maior ou igual a 97\% foram reunidas em OTUs (Unidades Taxonômicas Operacionais), gerando o total de 8.944 OTUs para todas as amostras, sendo 4.481 para F.N., 825 para F.P., 482 para R2, 1.180 para R5 e 1.976 para R9 (Tabela 5.13). Já para Singletons, os totais obtidos variaram de 240 a 1.635, com menor valor para R2 e maior valor para F.N. As porcentagens de singletons variaram de $36,49 \%$ (F.N.) a 51,57 \% (R9) (Tabela 5.13).

Tabela 5.13 - Resultados do sequenciamento das amostras F.N., F.P., R2, R5 e $\mathbf{R 9}$

\begin{tabular}{lccccc}
\hline \multicolumn{1}{c}{ Parâmetros } & F.N. & F.P. & R2 & R5 & R9 \\
\multicolumn{1}{c}{ RNAr 16S } & & & & \\
\hline Cobertura - Fórmula de Good & $98,43 \%$ & $99,55 \%$ & $99,12 \%$ & $99,41 \%$ & $99,3 \%$ \\
Total de sequências & 104.194 & 86.269 & 27.133 & 90.069 & 144.737 \\
Tamanho médio (pb) & $262 \pm 149$ & $275 \pm 141$ & $286 \pm 150$ & $277 \pm 149$ & $273 \pm 149$ \\
Total de OTUs (97\%) & 4.481 & 825 & 482 & 1.180 & 1.976 \\
Singletons & 1.635 & 387 & 240 & 530 & 1.019 \\
Total de OTUs após remoção & 2.846 & 438 & 242 & 650 & 957 \\
de singletons (classificação & & & & & \\
taxonômica) & & & & & \\
\multicolumn{1}{c}{ Estimadores de riqueza } & & & & & \\
Chao1 & 6.622 & 1.418 & 832 & 1.972 & 3.758 \\
Rarefação & $( \pm 165)$ & $( \pm 83)$ & $( \pm 67)$ & $( \pm 96)$ & $( \pm 136)$ \\
& 4.481 & 825 & 482 & 1.180 & 1.976 \\
Simpson (1- $D$ ) & $( \pm 1,414)$ & $( \pm 2,828)$ & $( \pm 3,536)$ & $( \pm 1,414)$ & $( \pm 5,657)$ \\
Dominância $(D)$ & & & & & \\
\hline Shannon (H) & 6,34 & 2,73 & 2,67 & 3,21 & 3,83 \\
& $( \pm 0,02)$ & $( \pm 0,02)$ & $( \pm 0,02)$ & $( \pm 0,02)$ & $( \pm 0,01)$ \\
& 0,9934 & 0,8345 & 0,8097 & 0,9041 & 0,9441 \\
& 0,0066 & 0,1655 & 0,1903 & 0,096 & 0,056 \\
\hline
\end{tabular}

Legenda: F.N.: fluido de rúmen in natura; F.P.: fluido de rúmen enriquecido; R2: 500 g; $80 \% ; 35^{\circ}$ C; R5: $1000 \mathrm{~g} ; 80 \%$; $55^{\circ} \mathrm{C}$; R9: $750 \mathrm{~g} ; 65 \%$; $45^{\circ} \mathrm{C}$

A análise de cobertura (fórmula de Good), por meio da qual estima-se a proporção da comunidade microbiana amplificada, permitiu verificar que acima de $98 \%$ de toda a 
comunidade microbiana foi amplificada (Tabela 5.13), o que é um indicativo da elevada cobertura da comunidade nas amostras.

Entretanto, foi também avaliado, por meio de curvas de rarefação, que para o nível taxonômico de espécie (97\% de similaridade), verificou-se curvas ascendentes, sem formação de platô (Figura 5.28), ou seja, o número de sequências obtidas não foi suficiente para amostrar a riqueza e diversidade dos filotipos da comunidade microbiana a nível de espécie. Assim, o nível taxonômico de espécie só poderia ser completamente acessado com o aumento do esforço amostral.

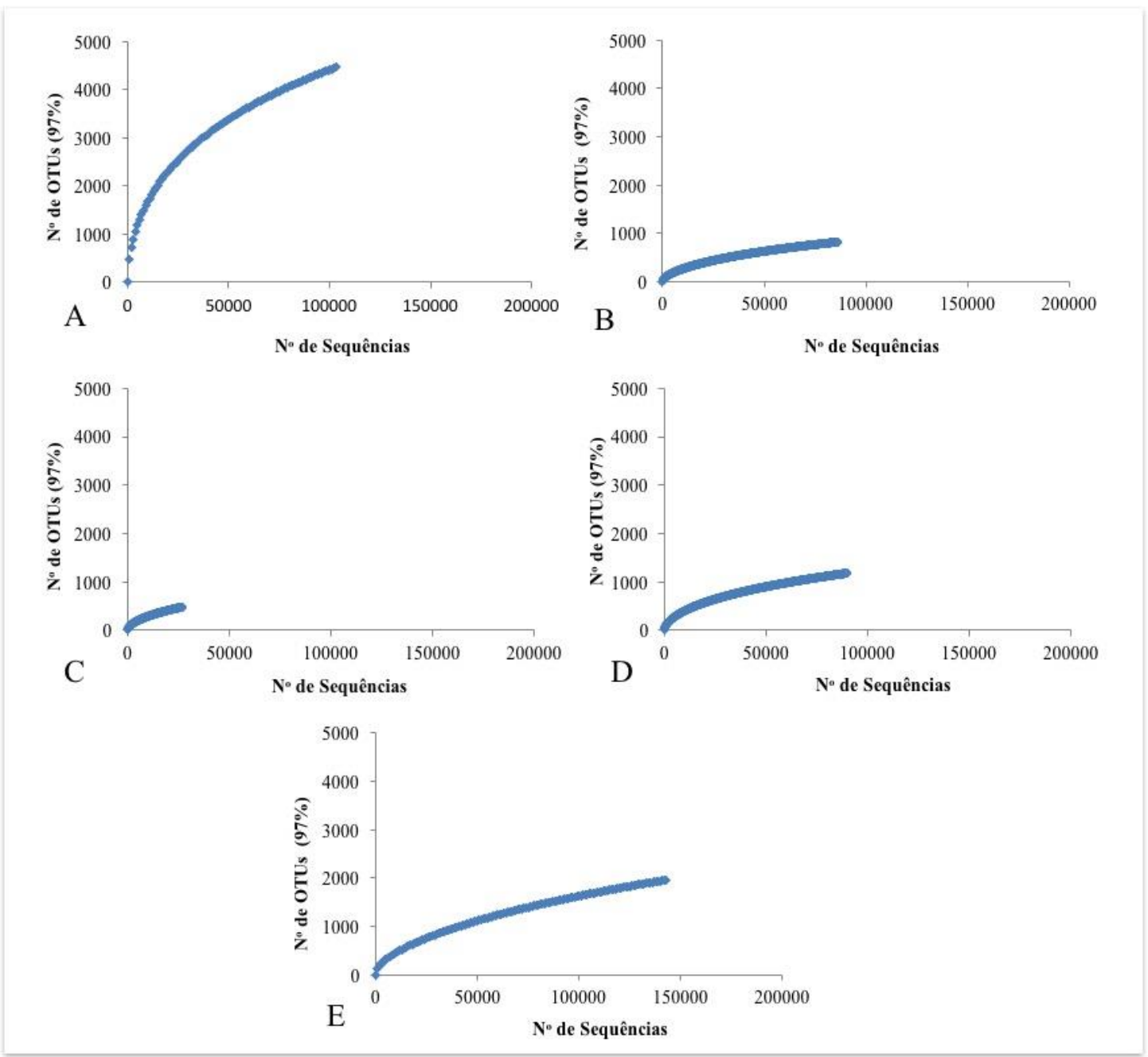

Figura 5.28 - Curvas de rarefação definidas para a porcentagem de similaridade de $97 \%$ (nível de espécie). Legenda: (A) F.N. (fluido de rúmen in natura); (B) F.P. (fluido de rúmen enriquecido); (C) lisímetro R2 $\left(35^{\circ} \mathrm{C}\right.$, $500 \mathrm{~g}, 80 \%)$; (D) lisímetro R5 (55 $\left.{ }^{\circ} \mathrm{C}, 1000 \mathrm{~g}, 80 \%\right)$; (E) lisímetro R9 (45ㄷ, $750 \mathrm{~g}, 65 \%)$ 
Em relação aos estimadores de riqueza Chao1 e Rarefação, verificou-se variação dos valores de 832-6.622 e 482-4.481, respectivamente (Tabela 5.13). Para a biomassa do fluido de rúmen in natura foi observada maior riqueza, sendo obtidos os valores de 6.622 e 4.481 para Chao1 e rarefação, respectivamente. Já para a biomassa do R2 $\left(35^{\circ} \mathrm{C}\right.$, $500 \mathrm{~g}, 80 \%$ ), verificou-se os menores valores de riqueza; ou seja de 832 e 482 para Chao1 e rarefação, respectivamente (Tabela 5.13).

O fluido de rúmen in natura foi a fonte de micro-organismos anaeróbios para obtenção da biomassa purificada (não metanogênica), portanto essa riqueza mais acentuada em relação às outras amostras era um resultado esperado. Esta biomassa purificada (F.P.), por sua vez, foi aplicada como inóculo nos lisímetros. Assim, esperavase maior riqueza na biomassa purificada do rúmem em relação àquelas dos lísimetros. Todavia, observou-se para a biomassa purificada (F.P.) e aquela de R2 $\left(35^{\circ} \mathrm{C}, 500 \mathrm{~g}\right.$, $80 \%$ ), menor riqueza dentre todas as analisadas, provavelmente devido à seleção de micro-organismos celulolíticos e fermentativos em consórcio mais selecionado. Em relação ao R2, as condições operacionais do lisímetro, provavelmente foram seletivas para algumas espécies, reduzindo a riqueza dessa amostra. Entretanto, para R5 $\left(55^{\circ} \mathrm{C}\right.$; $1000 \mathrm{~g} ; 80 \%)$ e R9 $\left(45^{\circ} \mathrm{C} ; 750 \mathrm{~g} ; 65 \%\right)$, provavelmente, as condições experimentais parecem ter favorecido o desenvolvimento de outras populações microbianas, levando ao aumento da riqueza.

Por meio do índice de Shannon, verificou-se elevada diversidade para a biomassa do fluido de rúmen in natura (6,34), em comparação com as outras amostras (Tabela 5.13). Esse resultado era esperado, pois o inóculo dos reatores foi o fluido de rúmen após enriquecimento seletivo, que certamente continha número mais reduzido de espécies na amostra. Dentre as condições operadas R2 $\left(35^{\circ} \mathrm{C}, 500 \mathrm{~g}, 80 \%\right), \mathrm{R} 5\left(55^{\circ} \mathrm{C} ; 1000 \mathrm{~g} ; 80 \%\right)$ e R9 $\left(45{ }^{\circ} \mathrm{C} ; 750 \mathrm{~g} ; 65 \%\right)$, foi verificada maior diversidade em R9 $(3,83)$ e menor diversidade em R2 $(2,67)$ (Tabela 5.13). Provavelmente, em R2 estavam concentradas as espécies fermentativas, produtoras de hidrogênio, pois foi a condição em que houve maior número de mol de hidrogênio detectado no headspace. $\mathrm{O}$ aumento da diversidade microbiana em R5 e R9 não foi favorável para a produção de hidrogênio nos lisímetros sob as condições operacionais impostas, observando-se nestas condições produção acentuada de etanol e metanol.

Levando-se em conta o índice de dominância de Simpson, o qual dá maior peso às espécies mais comuns, ou seja, de maior abundância relativa, verificou-se elevada diversidade nas amostras e distribuição pouco equâname, com exceção do fluido de 
rúmen in natura. Além disso, pôde-se observar que para as amostras F.P. e R2, o índice de dominância foi maior que para as outras, especialmente o fluido de rúmen in natura. Sendo assim, essas amostras continham menor número de espécies, porém com equitabilidade entre elas. Provavelmente, isso foi devido às condições de enriquecimento seletivo impostas, tais como temperatura mesofílica de incubação, meio de cultura rico em sais minerais, papel como único substrato, por exemplo, as quais levaram ao favorecimento de espécies degradadoras de celulose e/ou produtoras de hidrogênio, sem produção de metano.

O lisímetro R2 foi operado em temperatura mesofílica, a mesma em que o fluido de rúmen foi enriquecido, e foi, juntamente com R1, a melhor condição para obter hidrogênio a partir do papel dentre aquelas estudadas. Assim, pode-se concluir o favorecimento de populações celulolíticas e fermentativas em detrimento de outras presentes no consórcio.

Já para as condições R5 e R9, operadas em temperaturas mais elevadas, as condições não foram favoráveis para a produção de hidrogênio, o que provavelmente foi devido ao desenvolvimento de outras populações no consórcio. O aparecimento de outras espécies nessas condições resultou em maior riqueza da amostra e menor abundância relativa de cada espécie. Esses dados são corroborados pela maior ocorrência de singletons em R5 e R9 dentre todas as amostras (45\% e 51\%, respectivamente) (Tabela $5.13)$.

O índice de Bray-Curtis foi utilizado para quantificar a dissimilaridade composicional das 5 amostras analisadas, comparando a riqueza e abundância de espécies. O índice varia de 0 a 1 , sendo que quanto mais próximo de 0 , mais similares são as amostras, e quanto mais próximo de 1, maior é a dissimilaridade (BRAY; CURTIS, 1957). Por meio desse índice, foi construído o dendrograma da Figura 5.29. Foi possível observar, por meio do dendrograma, elevada diversidade entre as amostras analisadas, sendo que todos os índices foram menores que 0,4 (Figura 5.29).

Verificou-se similaridade em torno de 5\% entre as amostras dos lisímetros R5 e $\mathrm{R} 9$, e entre essas com o fluido de rúmen in natura. Por outro lado, as amostras do fluido de rúmen enriquecido e lisímetro R2 foram similares em aproximadamente 35\% (Figura 5.29). O fluido de rúmen in natura, que no rúmen de animais ruminantes permanece sob temperatura de $37^{\circ} \mathrm{C}$, foi submetido à condições que favoreceram o enriquecimento das populações bacterianas celulolíticas e fermentativas, sob temperatura mesofílica de $37^{\circ}$ C, e R2 foi operado sob temperatura mesofílica de $35^{\circ} \mathrm{C}$. Provavelmente, as condições 
operacionais de temperatura e substrato próximas entre F.P. e R2 foram preferenciais às populações celulolíticas e fermentativas, tornando-as dominante na cultura purificada. Porém, em R5 e R9, essas populações, possivelmente não foram favorecidas da mesma forma, e outras populações puderam se desenvolver, aumentando a diversidade da cultura e tornando-as mais próxima do fluido de rúmen in natura.

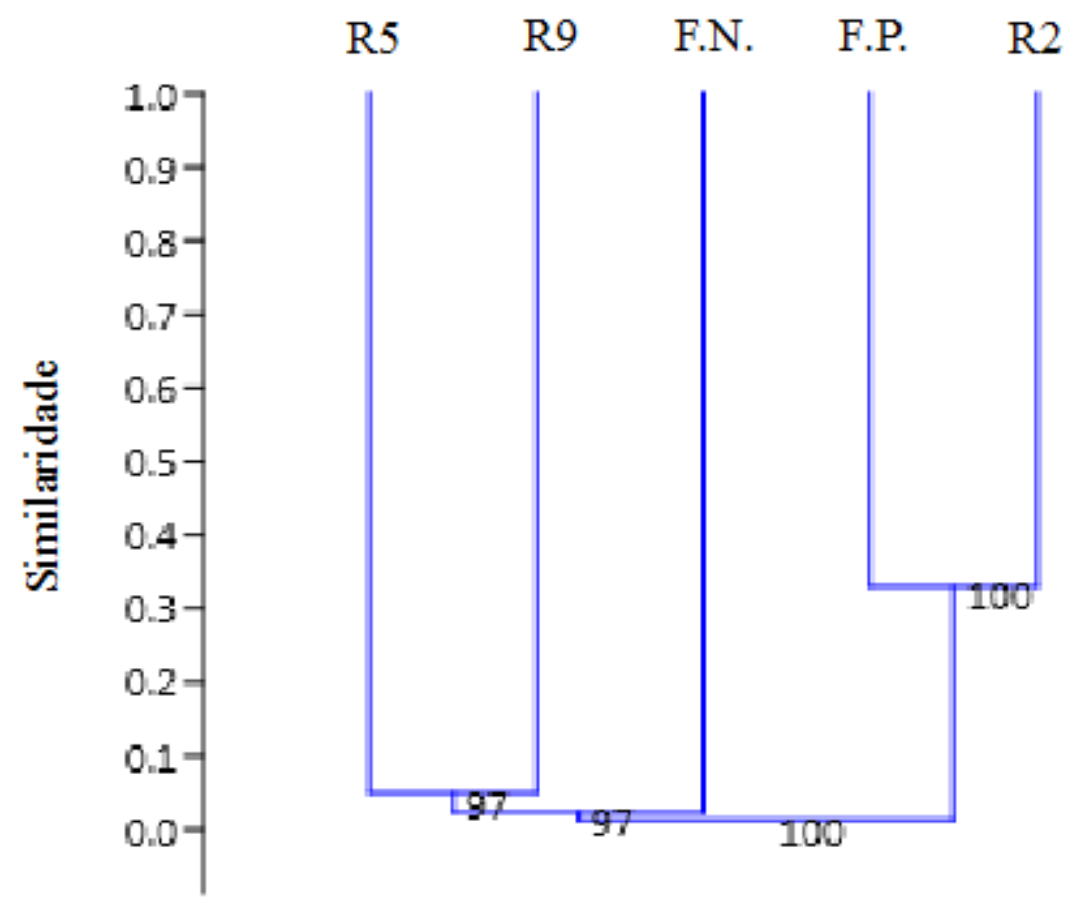

Figura 5.29 - Dendrograma baseado no índice de BrayCurtis para as amostras F.N. (fluido de rúmen in natura), F.P. (fluido de rúmen enriquecido), $R 2\left(35^{\circ} \mathrm{C} ; 500 \mathrm{~g} ; 80 \%\right)$, $\mathrm{R5}\left(55^{\circ} \mathrm{C} ; 1000 \mathrm{~g} ; 80 \%\right)$ e R9 $\left(45^{\circ} \mathrm{C} ; 750 \mathrm{~g} ; 65 \%\right)$

Na classificação taxonômica, observou-se que entre 93 e 100\% das sequências foram classificadas até Filo, 67 a 97\% até Família e 33 a $64 \%$ até Gênero para todas as amostras F.N., F.P., R2, R5 e R9. As OTUs foram distribuídas em diagramas de Venn para verificação da similaridade entre as amostras quanto aos Filos e Gêneros identificados. Foram realizados diagramas de Venn para comparação entre o fluido de rúmen in natura (F.N.) e após enriquecimento (F.P.) (Figura 5.30) e entre o fluido de rúmen enriquecido (F.P.) e amostras de R2, R5 e R9 (Figura 5.32). As porcentagens de abundância relativa de cada Filo e Gênero em cada amostra estão ilustradas nas Figuras 5.31A e B e Figura 5.33A-C. Para a construção dos gráficos de abundância relativa, foram usados os cut off de $0 \%$ e $0,5 \%$ para filo e gênero, respectivamente. 


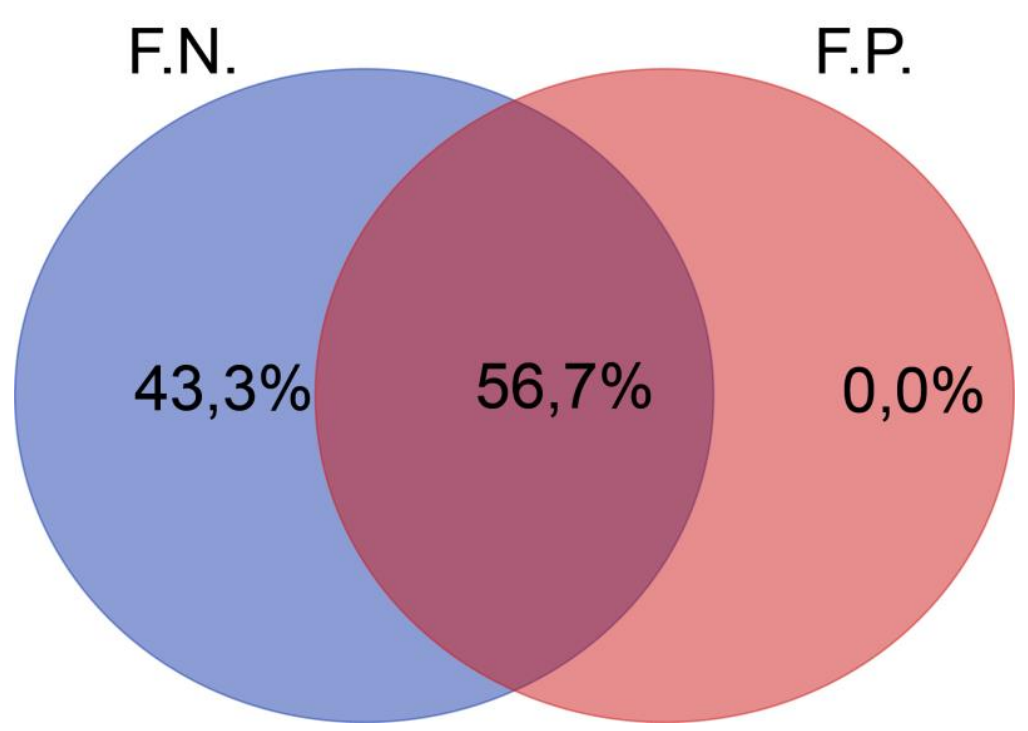

Figura 5.30 - Diagrama de Venn da presença e ausência de filos em função das sequências das amostras do fluido de rúmen in natura (F.N.) e fluido de rúmen enriquecido (F.P.)

Na amostra F.N., foram identificados representantes pertencentes a 7 Filos, com maior abundância para o Filo Firmicutes (46,1\%), seguido do Filo Bacteriodetes $(31,6 \%)$, os dois representando 63,2\% das sequências identificadas. Já na amostra F.P., foram identificados representantes pertencentes a 5 Filos, e observou-se aumento da abundância do Filo Bacteriodetes (43,7\%), seguido de redução da abundância do Filo Firmicutes (32\%). Ademais, diferentemente da amostra F.N., foi identificado representantes pertencentes ao Filo Proteobacteria na amostra F.P. com abundância relativa representativa, de 20,7\%. As condições impostas durante o enriquecimento seletivo do fluido de rúmen in natura, que objetivou a minimização da produção de metano, foram favoráveis ao crescimento de micro-organismos do Filo Bacteroidetes em detrimento do Filo Firmicutes e ao desenvolvimento de micro-organismos do Filo Proteoabacteria. 

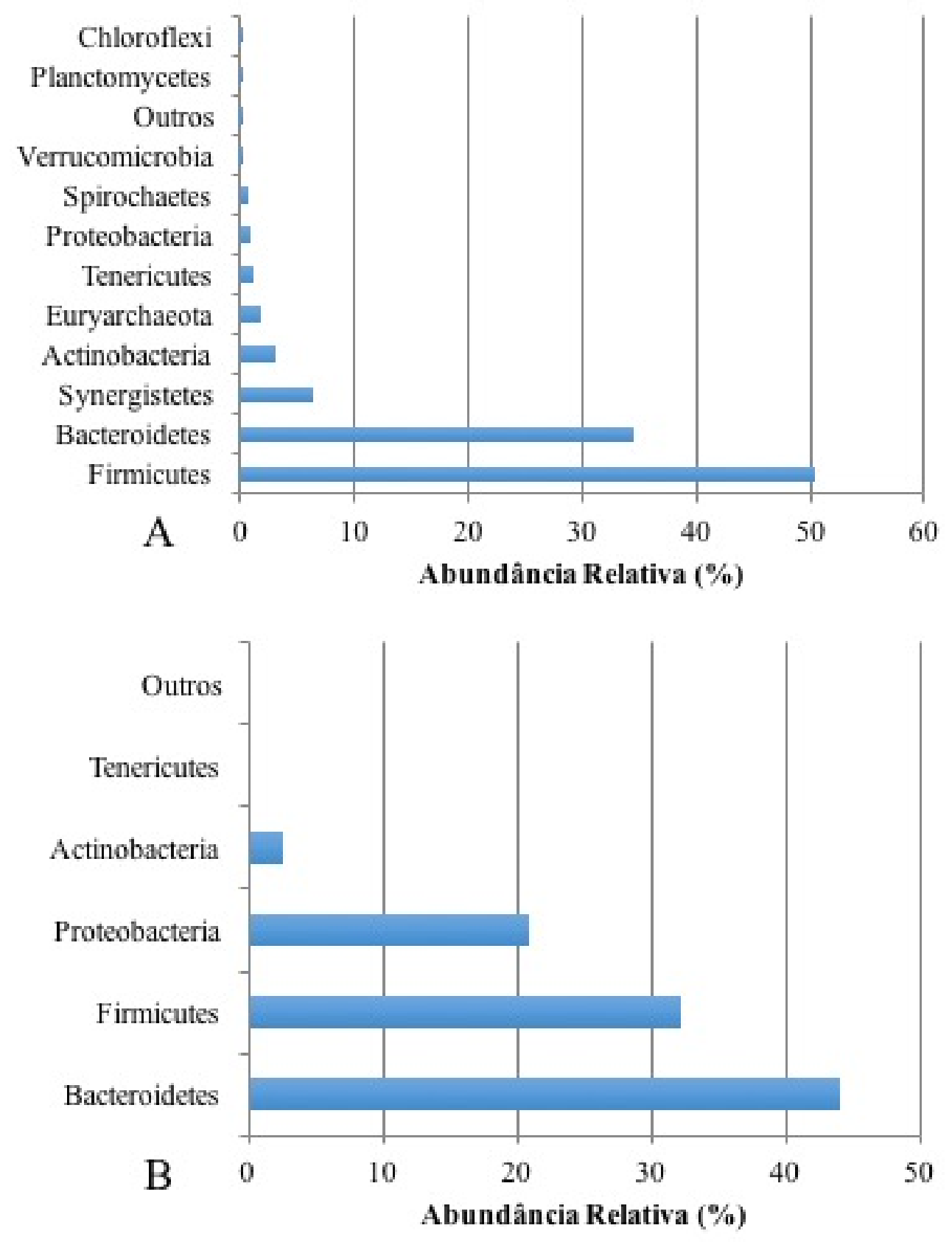

Figura 5.31 - Abundância relativa de filo: (A) F.N.: fluido de rúmen in natura e (B) F.P.: fluido de rúmen enriquecido

Rismani-Yazdi et al. (2013) verificaram o mesmo padrão de distribuição de filos para fluido de rúmen bovino usado como inóculo em células a combustível microbianas alimentadas com celulose para geração de eletricidade. Os autores relataram que os filos mais abundantes no inóculo original também foram Bacteroidetes e Firmicutes, somando 
$48 \%$ e $41 \%$ das sequências, respectivamente. A ressalva é que no presente estudo, a ordem de abundância foi Firmicutes e Bacteroidetes (Figura 5.31).

Similarmente ao presente estudo, Bacteroidetes foi composto principalmente pela família Prevotellaceae representada pelo gênero Prevotella, conhecido por suas habilidades em degradar polissacarídeos. Ainda em concordância, as principais famílias do Filo Firmicutes identificadas foram Ruminococcaceae e Lachnospiraceae, também presentes em maior abundância no presente estudo, com 15,4\% e 14,3\%, juntamente com representantes da família Veillonellaceae (16,7\%). A dominância de Prevotella na amostra do inóculo (fluido de rúmen bovino) também está de acordo com relatos prévios de Stevenson e Weimer, 2007. As famílias Veillonellaceae, Ruminococcaceae e Lachnospiraceae foram representadas principalmente pelos gêneros Succiniclasticum, Ruminococccus e Butyvibrio na amostra do inóculo in natura usado neste estudo.

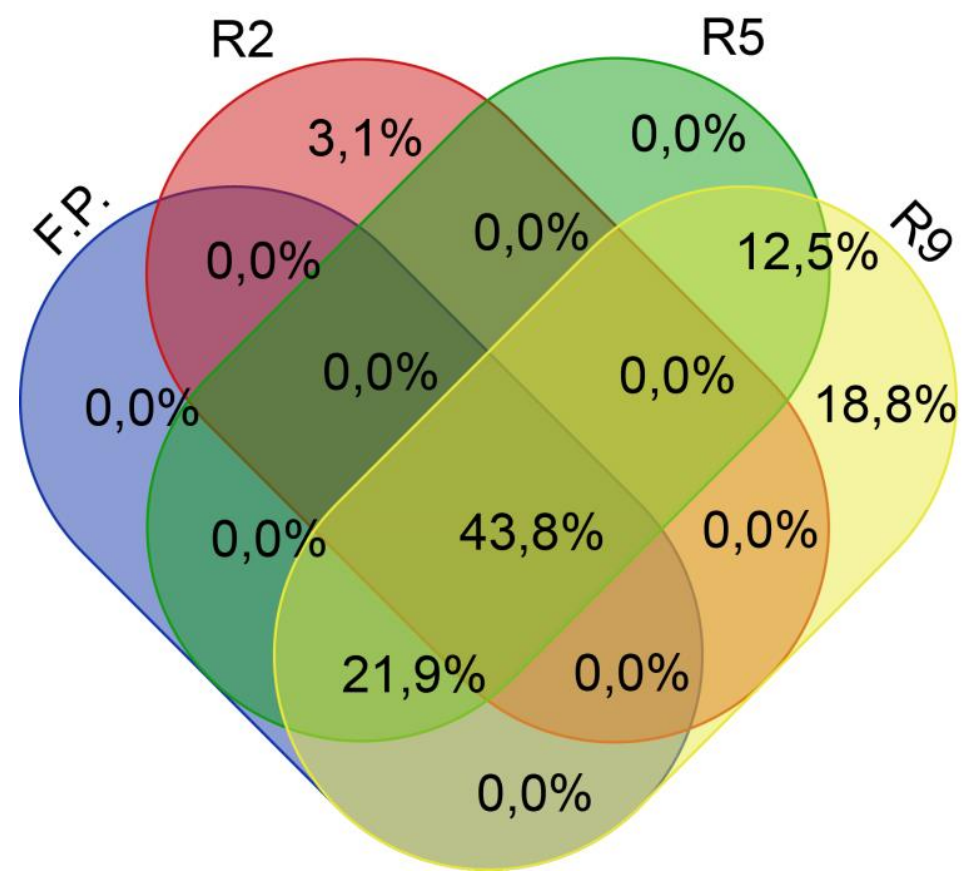

Figura 5.32 - Diagrama de Venn da presença e ausência de filos em função das sequências das amostras do fluido de rúmen enriquecido (F.P.), R2 $\left(35^{\circ} \mathrm{C} ; 500 \mathrm{~g} ; 80 \%\right)$, R5 (55ㄷ; $\left.1000 \mathrm{~g} ; 80 \%\right)$ e R9 $\left(45^{\circ} \mathrm{C} ; 750 \mathrm{~g} ; 65 \%\right)$

$\mathrm{Na}$ biomassa microbiana de $\mathrm{R} 2\left(35^{\circ} \mathrm{C} ; 500 \mathrm{~g} ; 80 \%\right)$, foram identificados representantes pertencentes a 5 Filos: Spirochaetes (0,2\%), Actinobacteria $(0,2 \%)$, 
Proteobacteria $(18,7 \%)$ e os prevalentes Firmicutes (32\%) e Bacteroidetes $(48,6 \%)$. Considerando que o lisímetro R2 foi operado nas mesmas condições de meio de cultivo, substrato e principalmente temperatura que F.P., as populações microbianas mais abundantes no inóculo F.P. se mantiveram favoráveis na biomassa de R2. Na biomassa microbiana de R5 $\left(55^{\circ} \mathrm{C} ; 1000 \mathrm{~g} ; 80 \%\right)$, entretanto, pôde-se observar favorecimento expressivo de bactérias pertencentes ao Filo Firmicutes $(90,1 \%)$, com redução significativa da porcentagem de abundância de Bacteroidetes para 5,8\% em relação ao inóculo F.P. $(48,6 \%)$.

A principal diferença entre F.P. e o lisímetro R5 foi a temperatura de incubação dos micro-organismos, que em R5 foi termofílica a $55^{\circ} \mathrm{C}$. Dessa forma, pode-se dizer que a temperatura foi o principal fator de influência na estrutura da comunidade microbiana, já que, tanto em R2, quanto em R5, o percentual de umidade inicial do substrato foi de $80 \%$. Outros Filos identificados foram Actinobacteria $(0,2 \%)$, Bacteroidetes (5,8\%), Chloroflexi $(0,3 \%)$, Euryarchaeota (0,2\%), Gemmatimonadetes $(2,5 \%)$, Proteobacteria $(0,2 \%)$, Spirochaetes $(0,2 \%)$ e Tenericutes $(0,3 \%)$ na biomassa de R5.

$\mathrm{Na}$ biomassa microbiana de $\mathrm{R} 9\left(45^{\circ} \mathrm{C} ; 750 \mathrm{~g} ; 65 \%\right)$, verificou-se maior abundância para o Filo Firmicutes (45,1\%), seguido do Filo Proteobacteria (36,8\%), Bacteroidetes (12,6\%), Gemmatimonadetes (3,3\%), Actinobacteria (1,4\%), Cyanobacteria $(0,2 \%)$ e Tenericutes $(0,2 \%)$. Diferentemente da biomassa de R5 e similarmente à biomassa de R2, verificou-se que representantes do filo Proteobacteria se desenvolveram na condição de R9 com abundância expressiva (Figura 5.33).

Dentre os Filos, 4 deles foram identificados nas cinco amostras estudadas: Actinobacteria (0,2 a 3,2\%), Bacteroidetes (5,8 a 48,7\%), Firmicutes (32,2 a 50,5\%) e Proteobacteria (0,2 a 36,8\%). Em F.N., R5 e R9, a maior abundância relativa foi para o Filo Firmicutes (> 45\%), já em F.P. e R2, a maior abundância relativa foi para o Filo Bacteroidetes (> 40\%) (Figuras 5.31 e Figura 5.33). 

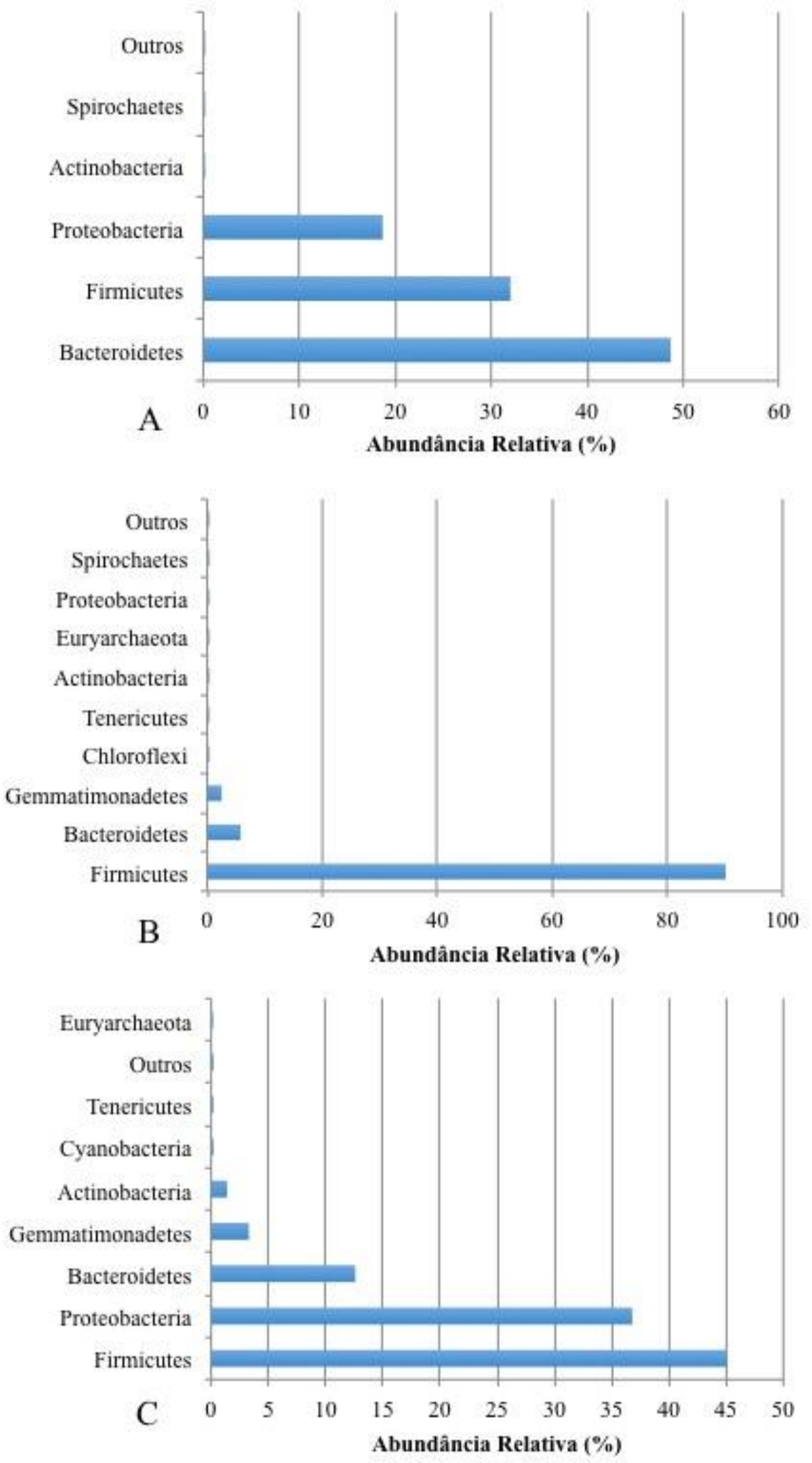

Figura 5.33 - Abundância relativa de filo (A) lisímetro R2 $\left(500 \mathrm{~g} ; 80 \%, 3^{\circ} \mathrm{C}\right)$; (B) lisímetro $\mathrm{R} 5\left(1000 \mathrm{~g} ; 80 \% ; 5^{\circ} \mathrm{C}\right)$ e (C) lisímetro $\mathrm{R9}\left(750 \mathrm{~g} ; 65 \% ; \mathbf{4 5}^{\circ} \mathrm{C}\right)$ 
O Filo Firmicutes inclui bactérias formadoras de endósporos, como os gêneros Clostridium, o principal gênero relacionado à produção de hidrogênio, e Bacillus (KAPDAN; KARGI, 2006). O filo Bacteroidetes contém elevada diversidade de bactérias. As bactérias pertencentes a esse filo são todas Gram-negativas, com diversidade metabólica elevada, e vão desde anaeróbios a aeróbios estritos. Membros do Filo Bacteroidetes têm colonizado diferentes nichos ecológicos, incluindo solo, oceano corpos d'água, além do trato gastrointestinal de animais, desempenhando diversas funções biológicas, com destaque para a degradação de polímeros orgânicos complexos, principalmente carboidratos (THOMAS et al., 2011).

Representantes de bactérias pertencentes aos filos Bacteroidetes e Firmicutes contêm micro-organismos que habitam o rúmen bovino, como por exemplo as espécies Prevotella ruminicola e Prevotella bryantii e as espécies Butyvibrio fibrisolvens, Ruminococcus flavifaciens, Ruminococcus albus e Eubacterium cellulosolvens, respectivamente (FLINT et al., 2008).

O Filo Proteobacteria é o mais amplo dentre os procariotos filogeneticamente e fenotipicamente. Este filo inclui cocos e bacilos Gram-negativos aeróbios e microaerofílicos, bacilos Gram-negativos retos, curvos e helicoidais; bactéria fototrófica anoxigênica, bactérias aeróbias quimiolitotróficas e gêneros associados, bacilos Gramnegativos anaeróbios facultativos, entre outros. Não há micro-organismos anaeróbios estritos nesse grupo. As classes do Filo Proteobacteria são Alfaproteobacteria, Betaproteobacteria, Gammaproteobacteria, Deltaproteobacteria e Episilonproteobacteria.

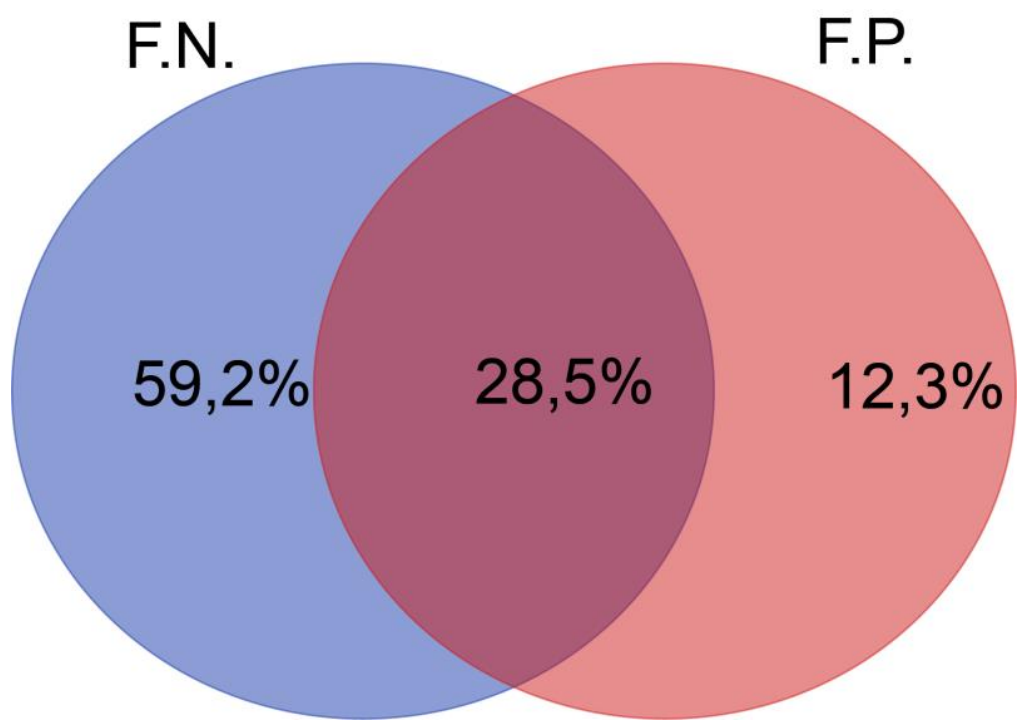

Figura 5.34 - Diagrama de Venn da presença e ausência de gêneros em função das sequências nas amostras de fluido de rúmen in natura (F.N.) e fluido de rúmen enriquecido (F.P.) 
Em relação aos Gêneros, apenas $28,5 \%$ dos identificados foram comuns às amostras de F.N. e F.P (Figura 5.34). Como já esperado, verificou-se redução da diversidade de gênero após o enriquecimento seletivo do fluido de rúmen. Além disso, na amostra de F.N. pôde-se observar maior equitabilidade entre os gêneros identificados. Já para F.P., além da diminuição do número de gêneros identificados, verificou-se aumento da abundância de populações específicas. Em F.N., os gêneros mais abundantes foram Prevotella, Succiniclasticum, e Butyrivibrio, com 37,5, 21,6 e 8,1\%, respectivamente (Figura 5.35A). Em contrapartida, para F.P., o principal gênero identificado foi Dysgonomonas com 67,5\%, seguido de Coprococcus $(7,26 \%)$ e Ruminococcus $(6,13 \%)$ (Figura 5.35B).
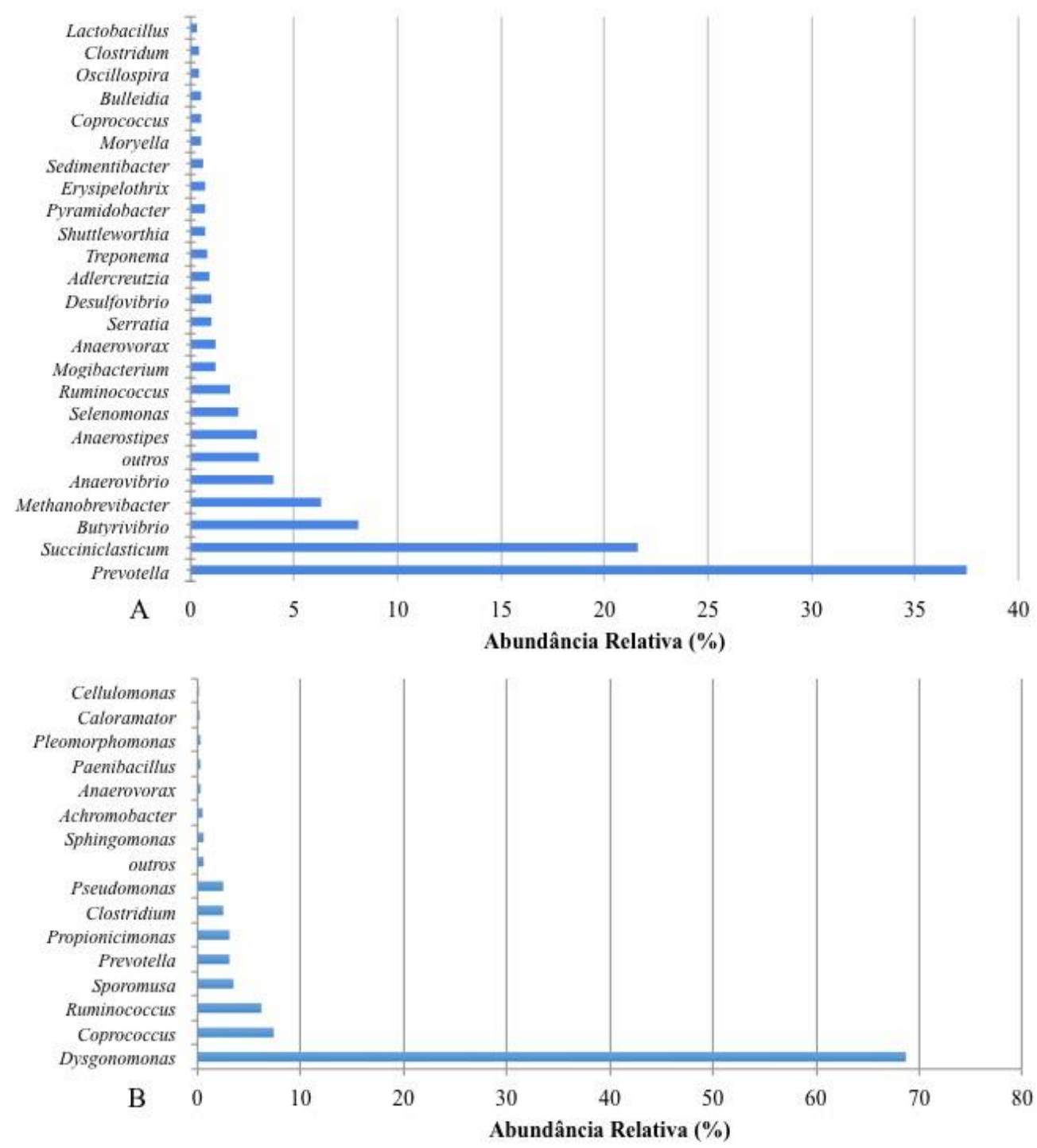

Figura 5.35 - Abundância relativa de gênero: (A) fluido de rúmen in natura (F.N.) (B) fluido de rúmen enriquecido (F.P.) 
Foi possível observar diversidade elevada entre os gêneros identificados nas amostras de micro-organismos do fluido de rúmen enriquecido (F.P.), R2(500 g; 80\%; $\left.35^{\circ} \mathrm{C}\right)$, R5 (1000 g; 80\%; 55 $\left.\mathrm{C}\right)$ e R9 $\left(750 \mathrm{~g} ; 65 \% ; 45^{\circ} \mathrm{C}\right)$ (Figura 5.36). Nas amostras do fluído de rúmen enriquecido (F.P.) e da biomassa dos lisímetros R2 e R5 verificou-se sempre um gênero com prevalência elevada, cuja abundância relativa foi entre 65 e 90\%; ou seja, Dysgonomonas para F.P. e R2 e Thermicanus para R5. Outros diversos gêneros identificados nestas amostras (F.P., R2 e R5) tinham abundância relativa de até 8,6\%, ou seja, com pouca representatividade no total de sequências classificadas.

Em contrapartida, na amostra do lisímetro R9 foram identificados diversos gêneros com maior equitabilidade, ou seja, os gêneros identificados estavam presentes com abundâncias relativas mais homogêneas e não houve prevalência de um único gênero como para as amostras citadas acima. Em R9, os principais gêneros identificados foram, em ordem crescente de abundância relativa, Mycoplana, Cohnella, Prevotella e Phaeospirillum. Enquanto em R5, operado a $55^{\circ} \mathrm{C}$, Thermicanus foi o principal microorganismo identificado, em $\mathrm{R} 9$, operado a $45^{\circ} \mathrm{C}$, este gênero foi pouco representativo na $\operatorname{amostra}(2,3 \%)$.

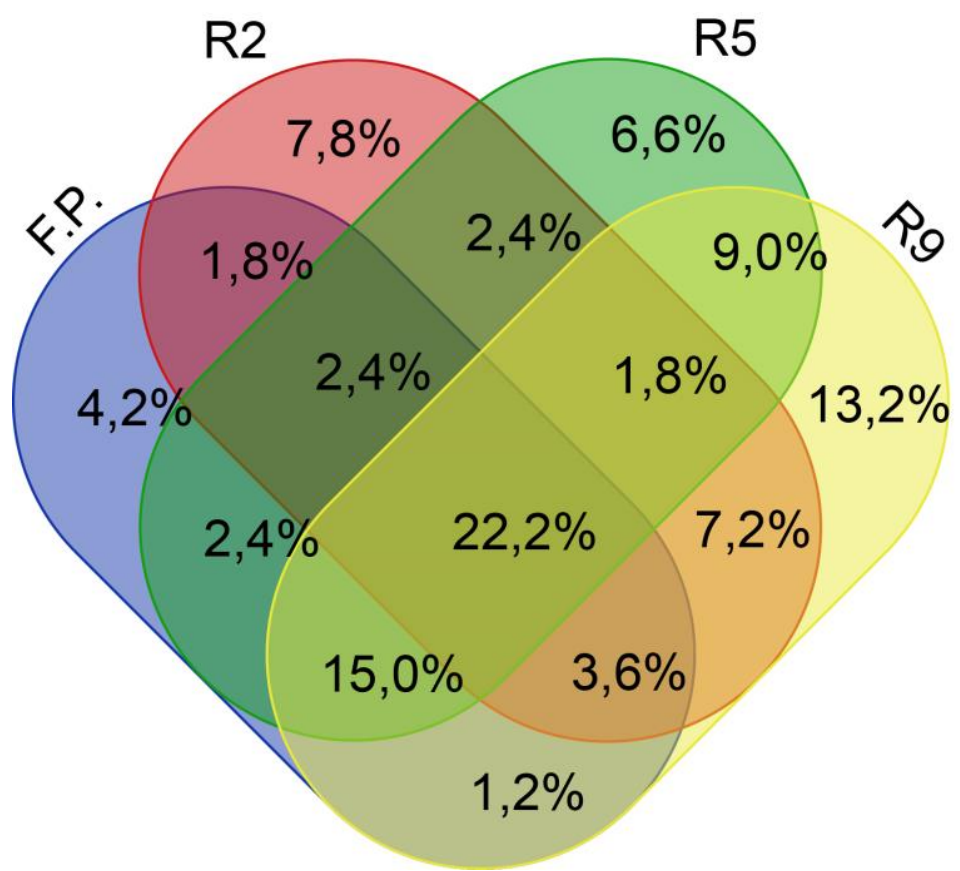

Figura 5.36 - Diagrama de Venn da presença e ausência de gêneros em função das sequências nas amostras fluido de rúmen enriquecido (F.P.), lisímetro $\mathrm{R2}\left(500 \mathrm{~g} ; 80 \% ; 3^{\circ} \mathrm{C}\right)$, lisímetro $\mathrm{R5}(1000$ $\left.\mathrm{g} ; 80 \% ; 5^{\circ} \mathrm{C}\right)$ e lisímetro R9 $\left(750 \mathrm{~g} ; 65 \% ; 4^{\circ} \mathrm{C}\right)$ 

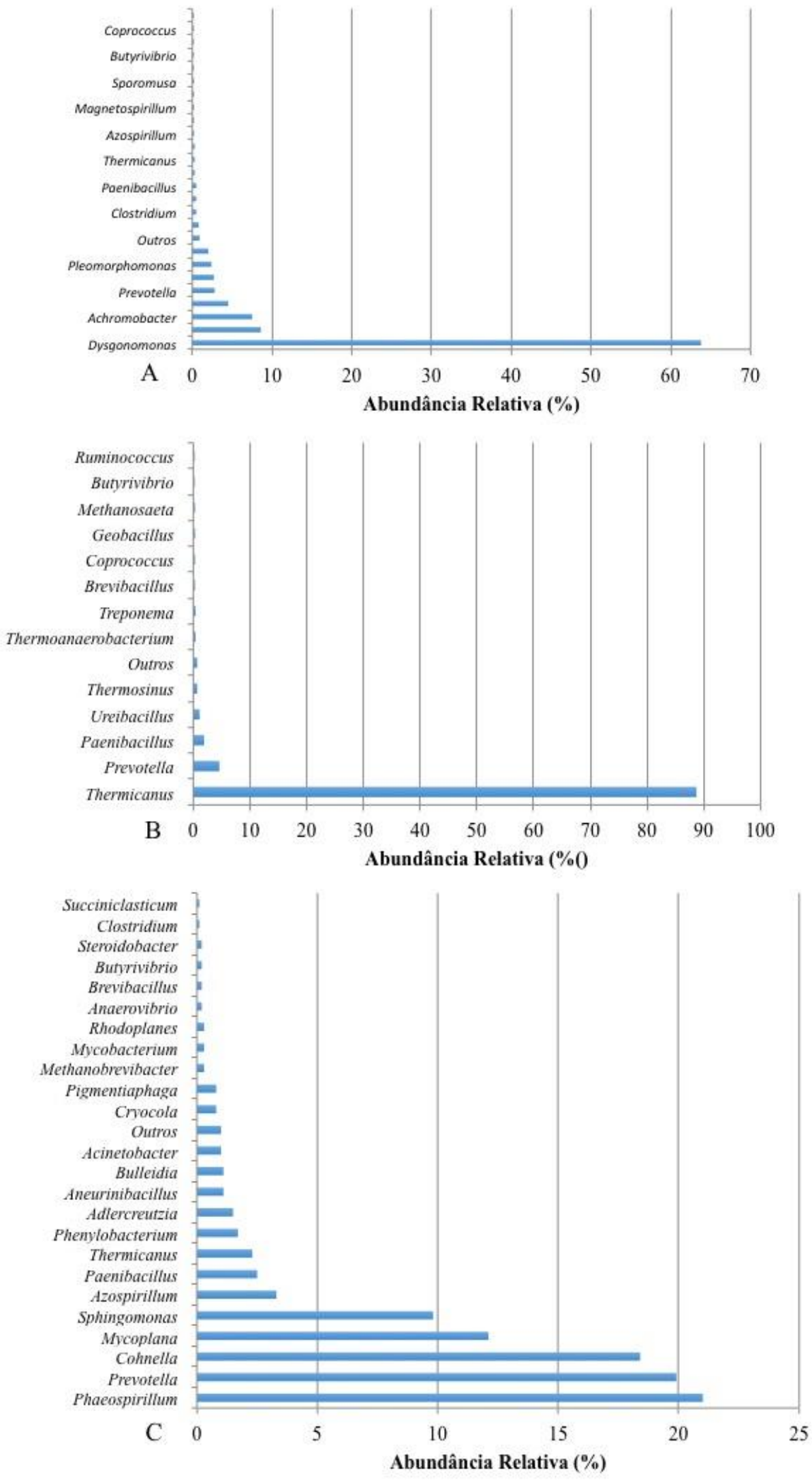

Figura 5.37 - Abundância relativa de gênero: (A) lisímetro R2 $\left(500 \mathrm{~g} ; 80 \% ; 3^{\circ} \mathrm{C}\right)$, (B) lisímetro R5 (1000 g; 80\%; 55 $\left.{ }^{\circ} \mathrm{C}\right)$ e (C) lisímetro $\mathrm{R9}\left(750 \mathrm{~g} ; 65 \% ; \mathbf{4 5}^{\circ} \mathrm{C}\right)$ 
Bactérias semelhantes a Prevotella foram identificadas com representatividade nas 4 amostras F.P., R2, R5 e R9 (Figura 5.35B e Figura 5.37). Faz parte da Família Prevotellaceae, Ordem Bacteroidales e Classe Bacteroidia do Filo Bacteroidetes. Tais bactérias são encontradas na forma de bacilos anaeróbios Gram-negativos, não formadores de endósporos e sacarolíticos, cujos principais produtos originados da fermentação de açúcares são os ácidos succínico e acético (KRIEG et al., 2010).

Prevotella é um gênero presente no pool de micro-organismos do fluido de rúmen, desempenhando importante papel hidrolítico, e foi o mais abundante na amostra de fluido de rúmen in natura analisada neste estudo. Nas condições mesofílicas usadas para enriquecimento seletivo do rúmen e durante a operação do R2, este gênero não foi o mais abundante dentre aqueles identificados. Entretanto, em R5 e R9, operados em temperaturas mais elevadas de 45 e $55^{\circ} \mathrm{C}$, esse gênero foi representativo, principalmente em R9.

Prevotella ruminicola é habitante do rúmen com crescimento ótimo a $30-37^{\circ} \mathrm{C}$. Os carboidratos fermentáveis por essa cepa são manose, sacarose, xilose, arabinose, galactose, frutose, celobiose, maltose, xilano, amido, pectina, entre outros. Para Prevotella ruminicola, os principais metabólitos produzidos a partir da fermentação da glicose descritos foram os ácidos acético, fórmico e succínico, com concentrações reduzidas de propiônico, isobutítico e isovalérico (BRYANT et al., 1958). Essas informações estão de acordo com os resultados obtidos neste estudo, já que essa espécie é celulolítica, ou seja, foi capaz de se manter nas condições impostas ao R5 e R9, por meio da degradação e fermentação de papel, produzindo ácidos orgânicos, por exemplo o ácido acético, que foi detectado em concentrações acentuadas no percolado dos lisímetros.

Outro gênero identificado em alta abundância em F.N. foi o Succiniclasticum que é composto por uma única espécie, Succiniclasticum ruminis (VAN GYLSWYK, 1995). Trata-se de bacilos Gram-negativos, anaeróbios, mesofílicos e não formadores de endósporo. Esses micro-organismos fermentam ácido succínico a ácido propiônico, ao passo que outros compostos como carboidratos, aminoácidos, e ácidos mono, di e tricarboxílicos não são fermentados. O ácido succínico é descarboxilado para produção de ácido propiônico e gás carbônico apenas. Em presença de ar no headspace, o crescimento desta bactéria é muito reduzido, portanto, seu desaparecimento nas amostras do fluido de rúmen enriquecido, R2, R5 e R9 pode estar relacionado com a formação de 
condições microaerofílicas nos lisímetros, comprovada pela presença de gêneros microaerofílicos ou até aeróbios na biomassa microbiana destes biorreatores.

Apesar da detecção de ácido propiônico no percolado dos lisímetros, em especial de R5, este ácido deve ser decorrente do metabolismo de outras bactérias acidogênicas, e não somente de Succinoclasticum, já que esta foi identificada apenas no inóculo original (fluido de rúmen in natura). Butyrivibrio já são bactérias anaeróbias estritas isoladas do rúmen de animais ruminantes e fezes humanas que fermentam carboidratos a ácidos orgânicos, sendo ácido butírico o principal subproduto. São capazes de degradar grande variedade de carboidratos e, portanto, contribuem significativamente para os bioprocessos do rúmen (FLINT et al., 2008).

Na biomassa microbiana do fluido de rúmen enriquecido (F.P.) e da condição R2, o principal gênero identificado foi Dysgonomonas, membro da família Porphyromonadaceae do Filo Bacteriodetes, estabelecido por Hofstad et al. (2000). Até o presente momento, este gênero inclui 6 espécies com nomes validamente publicados: D. gadei, D. capnocytophagoides, D. mossii, D. hofstadii, D. oryzarvi e D. macrotermitis. Os ácidos acético e láctico foram os principais subprodutos de fermentação descritos para todas as cepas, além dos ácidos propiônico, fórmico e succínico, ao passo que não há produção de gás em condições anaeróbias facultativas (YANG et al., 2014). Os seguintes substratos são usados como única fonte orgânica: glicose, xilose, celobiose, maltose, Dribose, amido, entre outros. São cocobacilos anaeróbios facultativos, Gram-negativos, com crescimento ótimo em faixa de $\mathrm{pH}$ 7,2-7,6 e temperatura de 35 a $37^{\circ} \mathrm{C}$ (YANG et al., 2014). O estabelecimento deste gênero em F.P. e R2 deve estar relacionado com a condição mesofílica de incubação nessas condições, além da capacidade hidrolítica de papel para fermentação a ácidos orgânicos. Como já descrito anteriormente, elevada concentração de ácido acético foi detectada na condição R2, corroborando o favorecimento de populações acidogênicas no consórcio microbiano dos lisímetros.

A identificação de Ruminococcus na cultura purificada do fluido de rúmen e no lisímetro R2, operado em temperatura mesofílica, se justifica pela habilidade dessas bactérias em hidrolisar e fermentar compostos celulósicos, produzindo hidrogênio, ácido acético e etanol, detectados, respectivamente no headspace e no percolado do lisímetro. Guell et al. (2015) relataram produção acumulada de 10,91 mmol/L de hidrogênio a partir de celulose pura em reatores anaeróbios operados em batelada sob condição mesofílica, usando Ruminococcus albus DMS20455. R. albus também foi usada como inóculo em biorreatores alimentados com sorgo e papel de diferentes tipos, e bons rendimentos de 
hidrogênio foram relatados (NTAIKOU et al., 2008, NTAIKOU; KOUTROS, KORNAROS, 2009).

Bactérias semelhantes a Ruminococcus são cocos em pares ou cadeias, estritamente anaeróbios, e em sua maioria, com coloração Gram-positiva. A espécie típica é Ruminococcus flavifaciens, porém outra espécie representativa é Ruminococcus albus. Foram isoladas primeiramente do rúmen, ceco e intestino grosso de diversos animais e humanos (HUNGATE, 1957). Essas bactérias quimioorganotróficas têm crescimento ótimo em temperatura na faixa $37-42^{\circ} \mathrm{C}$ na presença de carboidratos fermentáveis, cujos principais produtos da fermentação de carboidratos são os ácidos acético, fórmico, succínico, lático e etanol em proporções variadas. Hidrogênio é produzido por algumas espécies deste gênero (BRYANT, 1986).

As espécies Ruminococcus flavifaciens e Ruminococcus albus, ambas habitantes do fluido de rúmen não são formadoras de endósporos e apresentam elevadas taxas de hidrólise da celulose, uma das maiores dentre os micro-organismos celulolíticos. Tais espécies, conhecidamente produtoras de hidrogênio, fermentam celulose, celobiose e hemicelulose e hidrolisam pectina. A $R$. albus produz mais etanol, hidrogênio e gás carbônico que $R$. flavifaciens (NTAIKOU et al., 2008)

Outro gênero identificado na biomassa microbiana de R2 foi Coprococcus pertence à Família Lachnospiraceae e ao Filo Firmicutes. São cocos Gram-positivos, anaeróbios obrigatórios, e quimioorganotróficos também capazes de fermentar celobiose. As linhagens foram originalmente isoladas em roll tube com ágar esterilizado composto de fluido de rúmen, glicose e celobiose (HOLDEMAN; CATO, MORE, 1977). Os principais produtos de fermentação incluem os ácidos butírico e ácido acético, seguido de ácido fórmico e ácido propiônico. São filogeneticamente e bioquimicamente muito próximos do gênero Ruminococcus (ruminococci), entretanto não produzem hidrogênio. A temperatura ótima de crescimento de espécies do gênero Coprococcus descrita é de 37 e $45^{\circ} \mathrm{C}$, com crescimento moderado a 25 e $35^{\circ} \mathrm{C}$. Coprococcus eutactus, por exemplo, é reconhecida pela produção de ácido butírico, fórmico e lático a partir de glicose.

As elevadas concentrações de ácido acético produzidas durante o período de operação dos lisímetros podem estar relacionadas com a presença de Sporomusa na cultura purificada do fluido de rúmen, cuja abundância relativa foi de 3,5\%. Bactérias semelhantes a Sporomusa, foram descritas como acetogênicas, pertence à Família Veillonellaceae do Filo Firmicutes, são anaeróbias mesofílicas, formadoras de endósporos, capazes de crescer, tanto quimioorganotroficamente, quanto 
quimiolitotroficamente (MOLLER et al., 1984). Os principais substratos comumente utilizados por Sporomusa são $\mathrm{H}_{2}-\mathrm{CO}_{2}$, ácido fórmico, metanol, ácido lático e ácido pirúvico, mas o principal aspecto fisiológico de todas as espécies é a utilização de acetilcoA pela via "Wood-Ljungdahl (MOLLER et al., 1984; WOOD; LJUNGDAHL, 1991).

Sporomusa é conhecida por converter metanol a ácido acético, e já foi descrita como um dos principais gêneros detectados em uma célula a combustível microbiana alimentada com metanol, que convertia este composto a ácido acético, então oxidado por Geobacter para gerar energia (YAMAMURO et al., 2014).

Além dos gêneros anaeróbios estritos e facultativos identificados nas amostras microbianas estudadas, também foram identificados gêneros aeróbios, que podem ter se estabelecido pela capacidade de crescer em celulose nas condições de operação aplicadas, e pela provável ocorrência de zonas aeróbias dentro dos lisímetros. Exemplos destes gêneros são Achromobacter, Pseudomonas e Stenotrophomonas. Tais gêneros já foram encontrados em estudo, no qual cepas celulolíticas foram isoladas de solo com resíduos florestais em decomposição após cultivo em celulose (GHIO et al., 2012). Os autores concluíram que as colônias que não cresceram em celulose foram identificadas como Stenotrophomonas sp. (99\%), ao passo que isolados celulolíticos foram similares, dentre outros, a Paenibacillus sp., um micro-organismos anaeróbio facultivo de metabolismo fermentativo.

Segundo os autores, Stenotrophomonas não contêm os aparatos enzimáticos necessários para hidrolisar compostos celulósicos. Sendo assim, esse gênero identificado na amostra de R2 provavelmente se estabeleceu no consórcio devidos aos açúcares fermentáveis liberados da atividade hidrolítica do papel realizada por outras populações do consórcio.

Paenibacillus sp. são bactérias predominantemente anaeróbias facultativas. Durante o crescimento de Paenibacillus macerans em glicose, foi observada a rota Embden-Meyerhorf para produzir piruvato, o qual é convertido a etanol, ácido acético e pouca quantidade de ácido fórmico. Com o envelhecimento da cultura, o acetato e o formiato são catabolizados a $\mathrm{H}_{2}, \mathrm{CO}_{2}$ e acetona, ou seja, tanto gás $\mathrm{H}_{2}$ quanto ácidos voláteis foram diagnosticados nos testes com essa bactéria (WEIMER, 1984).

Já representantes semelhantes a Achromobacter, ao contrário da maioria dos gêneros identificados, é estritamente aeróbio e não fermentativo. Substratos como glicose, xilose e outras pentoses e hexoses são oxidados a vários graus, mas nunca fermentados (YABUUCHI; YANO, 1981). Este gênero foi identificado em amostra de 
solo nativo virgem após sucessivos enriquecimentos em meio de cultura contendo papel filtro ou celulose microcristalina como substrato celulósico a $28^{\circ} \mathrm{C}$ e aeração constante, a fim de isolar potenciais bactérias celulolíticas. Os gêneros Achromobacter e Pseudomonas foram identificados consistentemente em todas as colônias, com similaridade entre 99 e 100\% (BLAST) (ROMANO et al., 2013). Muitas espécies de Pseudomonas têm sido reportadas como celulolíticas, incluindo Pseudomonas putida, a qual sintetiza as enzimas celulase, hemicelulase e pectinase.

O primeiro relato da presença de Achromobacter em consórcio microbiano celulolítico foi em 2011 (YANG et al., 2011), no qual 86\% das sequências foram similares 99,9\% à espécie Achromobacter xylosoxidans. Os autores usaram palha, folhas e gramíneas em decomposição como fonte de micro-organismos para selecionar uma cultura capaz de crescer em gramínea seca e pré-tratada com $\mathrm{NaOH}$. Os autores citaram duas hipóteses: a degradação de lignocelulose por Achromobacter ou o consumo de açúcares liberados pela degradação das gramíneas por outras populações. Os resultados obtidos no presente estudo somado aos relatos de Yang et al. (2011) e Romano et al. (2013) possibilitam dizer que este se trata de um gênero celulolítico, e que, apesar da aplicação de condições anaeróbias no lisímetro, foi capaz de se desenvolver na biomassa microbiana do lisímetro R2 com 7,5\% de abundância.

Em suma, pôde-se observar que os principais gêneros identificados no fluido de rúmen enriquecido F.P. e no lisímetro R2, Prevotella, Dysgonomonas, e Coprococcus, são, em sua maioria, bactérias originárias do rúmen com potencial de hidrólise e fermentação da celulose a ácidos orgânicos, porém não a hidrogênio. Dentre as citadas, apenas o gênero Ruminococcus tem habilidade de fermentar celulose a hidrogênio com rendimentos satisfatórios. Além disso, Sporomusa também é uma bactéria que produz ácido acético a partir de diferentes substratos, inclusive do próprio hidrogênio $\left(\mathrm{H}_{2}\right)$. Este resultado explica a produção reduzida de hidrogênio observada em R2 e as elevadas concentrações de ácidos orgânicos presentes do percolado deste lisímetro, em torno de 17.000 e $4.000 \mathrm{mg} / \mathrm{L}$ de ácido acético e ácido butírico, respectivamente, por exemplo.

No lisímetro R5, o principal gênero identificado foi Thermicanus, que é representado por uma única espécie, a Thermicanus aegyptius e pertence à ordem Bacillales e Filo Firmicutes (GÕBNER et al., 1999). Esta espécie foi primeiramente isolada de solo do Egito, cuja amostra foi enriquecida em meio de cultura com $\mathrm{pH}$ neutro formulado para o enriquecimento de micro-organismos acetogênicos a $55^{\circ} \mathrm{C}$. Este gênero foi primeiramente identificado juntamente com um micro-organismo acetogênico 
denominado Moorella thermoacetica, indicando um possível comensalismo entre ambas espécies, ou seja, de Thermicanus com espécies acetogênicas (GÕBNER et al., 1999).

Thermicanus são bacilos termofílicos Gram-positivos, microaerofílicos facultativos, e não formadores de endósporos, com crescimento ótimo a 55-60 $\mathrm{C}$ e $\mathrm{pH}$ entre 6,5 e 7,0. Esta bactéria é capaz de produzir hidrogênio, além de ácidos acético, succínico, fórmico, láctico e etanol a partir de ampla gama de substratos como glicose, celobiose e xilose, entre outros açúcares. Em condições óxicas, fermentam também ácido acético, ácido fórmico e ácido succínico, liberando os mesmos produtos de fermentação. Dentre as condições termofílicas estudadas, R5 foi a única em que se detectou hidrogênio no headspace, mesmo que em quantidade reduzida, além de elevadas concentrações de ácido acético e etanol, de aproximadamente, 10.000 e $2.300 \mathrm{mg} / \mathrm{L}$, respectivamente.

As concentrações de ácidos orgânicos e álcoois no percolado dos lisímetros refletiu na atividade hidrolítica e fermentativa da cultura microbiana sobre o papel (substrato). Nos lisímetros, o hidrogênio produzido, por exemplo, por espécies como a Thermicanus pode ter sido rapidamente convertido a ácido acético, não sendo detectado no headspace, em concordância com o relato de Gobner et al. (1999). Além disso, foi detectado concentrações relevantes de etanol no percolado do lisímetro R5, com decréscimo gradativo de sua concentração ao longo do período de operação, Etanol também é subproduto de fermentação de carboidratos pela bactéria Thermicanus e, provavelmente, também foi convertido a ácido acético por bactérias acetogênicas presentes na cultura microbiana. A presença de bactérias acetogênicas é corroborada pelas crescentes e elevadas concentrações de ácido acético no percolado dos lisímetros. $\mathrm{O}$ metabolismo hidrolítico da Thermicanus, bactéria capaz de hidrolisar celobiose (papel) favoreceu sua prevalência na cultura microbiana do lisímetro R5.

Outros gêneros de bactérias termofílicas identificados na amostra de R5 foram Thermoanaerobacterium e Thermosinus, com abundancias relativas reduzidas de $0,4 \% \mathrm{e}$ $0,7 \%$, respectivamente. Thermoanaerobacterium é um gênero de bactérias termofílicas, anaeróbias estritas, cujos principais subprodutos da fermentação de carboidratos são ácido acético, ácido lático, etanol, hidrogênio e gás carbônico, além de ácido butírico e butanol a depender da espécie (LEE et al., 1993). Algumas espécies são celulolíticas. Thermoanaerobacterium já foi descrito em diversos estudos sobre produção termofílica de hidrogênio a partir de diferentes substratos, como vinhaça, celulose/papel, entre outros (CARVER et al., 2012; SANTOS et al., 2014). Thermoanaerobacterium e Clostridium foram predominantes em consórcio anaeróbio usado como inóculo para fermentação de 
filtro de papel a 50 e $60^{\circ} \mathrm{C}$, cujos metabólitos detectados foram hidrogênio, gás carbônico, etanol e ácido acético (CARVER et al., 2012). Em experimento contínuo de longa de duração para produção de hidrogênio sob temperatura termofílica $\left(55^{\circ} \mathrm{C}\right)$ a partir de celulose as cepas microbianas termofílicas e celulolíticas foram similares à Thermoanaerobacterium thermosaccharolytium, Clostridium sp. e Enterobacter cloacae. Os autores descreveram rendimento de $15,4 \mathrm{~mol} \mathrm{H}_{2} / \mathrm{kg}$ celulose e ácidos acético e butírico como principais metabólitos no meio líquido (JIANG et al., 2015). Ambos os relatos fortalecem a presença deste gênero na biomassa de R5, já que neste lisímetro foi detectado hidrogênio e foram observadas no percolado elevadas concentrações de etanol, metanol e ácido acético.

Thermosinus, assim como Sporomusa, pertencem a Família Veillonellaceae, Filo Firmicutes. A única espécie Thermosinus carboxydivorans trata-se de bacilos curvos anaeróbios estritos, Gram-negativos e não formadores de endósporos; fermentam carboidratos simples sob condições termofílicas e podem crescer quimiolitotroficamente em $\mathrm{CO}$, formando quantidades equimolares de $\mathrm{H}_{2}$ e $\mathrm{CO}_{2}$ (SOKOLOVA et al., 2004). Seu crescimento é ótimo nas faixas de temperatura e $\mathrm{pH}$ de $40-68^{\circ} \mathrm{C}$ e 6,5-7,6. Apesar do metabolismo quimiolitotrófico, provavelmente estavam presentes no consórcio do lisímetro R5 pela fermentação de substratos fermentáveis liberados da hidrólise de papel, cujos principais metabólitos são hidrogênio, gás carbônico e ácido acético. A baixa abundância relativa deve estar relacionada com as condições microaerofílicas no interior do lisímetro, além da incapacidade de degradar substratos complexos como papel (celulose).

Phaeospirillum, o mais abundante na biomassa do lisímetro R9, pertence a família Rhodospirillaceae, ordem Rhodospirillales, classe Alpharoteobacteria e Filo Proteobacteria. São bactérias de formato espiral, anoxigênicas e fototróficas acidofílicas (BURGESS et al., 1993). Espécies como Phaeospirillum molischianum e Phaeospirillum fubrum usam como fonte de carbono os seguintes compostos: ácidos acético, butírico, capróico, fumárico, lático, propiônico, pirúvico, succínico e valérico, além dos álcoois etanol e metanol. As baixas concentrações de ácidos detectadas no percolado dos lisímetros R9 e R10 podem estar relacionadas ao consumo desses compostos por bactérias acidofílicas.

O elevado teor de ácidos orgânicos no percolado propiciou o desenvolvimento de bactérias acidófilas consumidoras de ácidos. O baixo teor de ácidos detectado no percolado de R9 pode estar relacionado com o consumo desses compostos pelas bactérias 
acidófilas identificadas na biomassa. Prevotella também foi identificada em maior abundância, provavelmente foi a responsável pela hidrólise do papel nesta condição R9.

Outro gênero predominante no consórcio microbiano detectado em R9 foi o Cohnella, um bacilo aeróbio, Gram-positivo e formador de endósporo, que foi primeiramente isolado de planta industrial de produção de amido (KAMPFER et a., 2006). Este gênero pertence à Família Paenibacillaceae e apresenta relação filogenética com Paenibacillus, outro gênero detectado nas amostras estudadas. A espécie-tipo Cohnella thermotolerans tem metabolismo oxidativo e não produtor de ácidos, e usa como única fonte de carbono diversos carboidratos, dentre eles, celobiose e glicose. A capacidade de hidrolisar celobiose e o fato de ser termotolerante justifica seu favorecimento no lisímetro R9, operado sob $45^{\circ} \mathrm{C}$ (KAMPFER et al., 2006). 
Tabela 5.14 - Principais gêneros identificados nas 5 amostras estudadas e suas características metabólicas

\begin{tabular}{|c|c|c|c|c|c|c|}
\hline Gêneros & $\begin{array}{c}\text { Hidrólise } \\
\text { Celulose/Celo- } \\
\text { biose }\end{array}$ & $\begin{array}{l}\text { Produção de } \\
\text { hidrogênio }\end{array}$ & $\begin{array}{c}\text { Produção de } \\
\text { ácidos orgânicos } \\
\text { voláteis (AOVs) }\end{array}$ & $\begin{array}{l}\text { Produção de } \\
\text { etanol }\end{array}$ & $\begin{array}{l}\text { Consumidoras de } \\
\text { AOVs e álcoois }\end{array}$ & $\begin{array}{c}\text { Acetogênicas/ } \\
\text { Homoacetogênicas }\end{array}$ \\
\hline Prevotella & + & - & + & - & - & - \\
\hline Succiniclasticum & - & - & + & - & + & - \\
\hline Butyrivibrio & + & + & + & & - & - \\
\hline Dysgonomonas & + & - & + & & - & - \\
\hline Ruminococcus & + & + & + & + & - & - \\
\hline Coprococcus & + & + & + & + & - & - \\
\hline Sporomusa & - & - & - & - & + & + \\
\hline Achromobacter & + & - & - & - & & - \\
\hline Paenibacillus & + & + & + & - & - & - \\
\hline Thermicanus & + & + & + & + & - & - \\
\hline Thermoanaerobacterium & + & + & + & + & - & - \\
\hline Phaeospirillum & - & - & - & - & + & - \\
\hline Cohnella & + & - & - & - & - & - \\
\hline
\end{tabular}


No ecossistema ruminal, a metanogênese e a homoacetogênese são comuns e representam uma potencial desvantagem quando se utiliza este consórcio altamente celulolítico como inóculo em reatores anaeróbios alimentados com celulose ou substratos celulósicos para produção de hidrogênio ou subprodutos da fermentação acidogênica. Apesar da eliminação da metanogênese na cultura purificada do fluido de rúmen, a acetogênese e homoacetogênese foram metabolismos preferenciais nos lisímetros confirmados pelas elevadas concentrações de ácido acético detectadas em todas as condições estudadas. Ou seja, a cultura microbiana foi efetiva para hidrólise e fermentação de celulose, entretanto, o estabelecimento de populações fermentativas acidogênicas não produtoras de hidrogênio e de populações acetogênicas favoreceram um lisímetro produtor de energia preferencialmente na forma de ácidos orgânicos ao invés de hidrogênio.

A ocorrência de Clostridium e Thermoanaerobacterium, conhecidas produtoras de hidrogênio, em abundâncias relativas muito reduzidas nas amostras estudadas deve estar relacionada à ausência de anaerobiose estrita no interior dos lisímetros. Assim, foi observado o desenvolvimento de espécies anaeróbias facultativas e/ou microaerofílicas, em sua maioria, capazes de degradar celulose.

Muitos estudos têm descrito a utilização de ácido acético como substrato preferencial de células a combustíveis microbianas para geração de energia elétrica (KARRA et al., 2013; WANG, REN, 2014). Em outro estudo verificou-se o uso de célula a combustível alimentada com metanol, o qual foi convertido a ácido acético para geração de energia elétrica (YAMAMURO et al., 2014).

Bactérias do gênero Sporomusa e Dysgonomonas são largamente descritas em trabalhos com sistemas eletroquímicos microbianos (YAMAMURO et al., 2014; ZHANG et al., 2011). Ademais, os ácidos orgânicos têm sido cada vez mais descritos como commodities químicas de alto valor agregado. Sendo assim, os efluentes dos lisímetros podem ser utilizados como substrato para sistemas eletroquímicos para geração de energia com sucesso, uma vez que nas condições experimentais impostas obteve-se expressivas concentrações de ácido acético.

A prospecção dessas bactérias celulolíticas detectadas na biomassa dos lisímetros operados em diferentes temperaturas pode promover descobertas quanto às suas atividades celulolíticas e potencial como fonte de novas enzimas hidrolíticas. A aplicação dessas enzimas em sistemas de produção de biocombustíveis a partir de resíduos lignocelulósicos pode levar à redução de custos do bioprocesso como um todo. 
Além disso, tais micro-organismos podem também ser aplicados como inóculo de células a combustível microbianas. A grande maioria dos gêneros detectados nas amostras de biomassa microbianas analisadas no presente estudo foi identificada em estudos prévios que buscam novas populações microbianas celulolíticas como fonte de enzimas que degradem celulose, hemicelulose e lignina para aplicação em sistemas de produção de etanol de segunda geração ou células a combustível microbianas alimentadas com resíduos (GHIO et al., 2012; ROMANO et al., 2013). 


\subsection{Considerações Finais}

A fermentação ocorrente nos lisímetros se caracterizou como fermentação de substrato sólido, já que o papel não estava submerso em água e continha teor de umidade inicial abaixo da saturação (50-80\%).

O enriquecimento seletivo do fluido de rúmen levando-o a uma cultura microbiana não metanogênica por meio de diluições seriadas foi efetivo, já que não foi detectado metano no biogás em nenhuma das condições estudadas, e por meio de sequenciamento massivo, verificou-se prevalência de bactérias fermentativas.

O grau de hidrólise do papel e fermentação dos açúcares resultantes diferenciou de acordo com as variáveis impostas em cada condição de operação do planejamento experimental. Por meio dos resultados obtidos, foi possível concluir que a temperatura termofilica foi mais favorável para a hidrólise e fermentação de papel, pois maior quantidade de papel foi hidrolisada nos lisímetros operados nesta condição, elevadas concentrações de compostos solúveis foram detectadas e em menor período de operação, comparado com a temperatura mesofílica. A hidrólise de papel em condições de umidade reduzida (50-65\%) foi menos influenciada pelas condições impostas do que a fermentação dos carboidratos resultantes, visto que concentrações elevadas de carboidratos foram detectadas em R8, R9 e R10, se comparadas ao R1 a R6, porém as concentrações de ácidos voláteis e ácidos foram muito reduzidas no percolado destes lisímetros.

A temperatura de incubação dos lisímetros foi o principal fator de influência nas rotas metabólicas fermentativas desempenhadas pelos micro-organismos. A produção de hidrogênio foi favorecida sob temperatura mesofílica (lisímetros R1 e R2), condição em que se observou concentrações expressivas de ácido acético e ácido butírico. Pode-se concluir que esses foram os principais metabolismos de geração de hidrogênio neste estudo.

Nas operações a $35^{\circ} \mathrm{C}$, foram observadas concentrações reduzidas de ácidos propiônico no percolado, além de concentrações menores de álcoois, se comparada às temperaturas de 45 e $55^{\circ} \mathrm{C}$. Nestas últimas, em que a produção de hidrogênio foi muito reduzida ou ausente, houve favorecimento da geração de álcoois e concentrações mais elevadas de ácido propiônico, o qual é diretamente envolvido no consumo de hidrogênio. 
A ocorrência de homoacetogênese foi certeira nos lisímetros, em especial nas operações mesofílicas R1 e R2. A elevada concentração de ácido acético no percolado, não acompanhada pelo aumento do número de mol de hidrogênio no headspace, pode significar consumo em meio líquido deste gás para conversão direta a esse ácido orgânico. O gênero homoacetogênico Sporomusa foi um dos principais gêneros identificados na cultura de R2, corroborando a ocorrência deste metabolismo sob as condições estudadas.

A redução do pH inicial dos lisímetros para 5,5 não foi efetiva para a minimização da atividade homoacetogênica, já que esta foi observada nos lisímetros. Isso provavelmente deveu-se ao aumento do $\mathrm{pH}$ decorrente da liberação de carbonato de cálcio durante a hidrólise de papel, o que manteve o pH na faixa neutra durante toda a operação.

O desempenho reduzido dos lisímetros sob as condições estudadas pode estar relacionado à lavagem dos micro-organismos aderidos ao leito de papel ao longo da operação, devido à aspersão frequente de meio de cultura, visto que houve redução gradativa do teor de STV percolado em todas as condições estudadas.

O teor de umidade foi a única variável cujo aumento de 50 para $80 \%$ teve efeito estatisticamente significativo para a produção de hidrogênio, ácido acético e etanol. Ademais, por meio de análise geral dos parâmetros avaliados, principalmente da porcentagem de consumo de papel ao longo das operações, verificou-se que o teor de umidade inicial de $80 \%$ foi determinante para o estabelecimento da microbiota nos lisímetros.

De acordo com os resultados, pode-se afirmar que a disponibilidade de água e sais minerais esteve relacionada ao desempenho celulolítico e fermentativo da biomassa microbiana, e o teor reduzido de água, apesar de interessante operacionalmente, influenciou negativamente no desempenho obtido para o lisímetro.

A temperatura de operação influenciou diretamente os metabolismos desempenhados pelos micro-organismos em decorrência de ser um fator determinante no estabelecimento das populações microbianas sob as diferentes condições estudadas, tendo sido todos os lisímetros inoculados com fluido de rúmen enriquecido. Para as temperaturas estudadas, verificou-se prevalência de gêneros microbianos diferentes: Dysgonomonas para $35^{\circ} \mathrm{C}$, Thermicanus para $55^{\circ} \mathrm{C}$ e Phaeospirillum para $45^{\circ} \mathrm{C}$.

A massa de substrato (papel) adicionada não foi um fator de efeito estatisticamente significativo para a produção de nenhum dos compostos analisados, portanto, não teve influência na atividade microbiana de hidrólise e fermentação do papel. 
Pode-se observar porcentagens de consumo de papel semelhantes para os reatores R1, R2; R5 e R6, os quais foram operados com 500 e 1000 g de papel, respectivamente.

As diluições seriadas do fluido de rúmen levaram ao favorecimento de bactérias dos Filos Bacteroidetes e Firmicutes, relacionados com hidrólise de polissacarídeos complexos e fermentação de carboidratos, respectivamente. Devido à variação nas condições operacionais impostas e da grande diversidade de micro-organismos presentes no fluido de rúmen, houve desenvolvimento também do Filo Proteobacteria.

Este trabalho possibilitou concluir que, apesar de ser operacionalmente interessante a economia de água em sistemas de tratamento de resíduos e geração de energia, é necessário teor de umidade mínimo para o crescimento e atividade dos microorganismos. Além disso, a temperatura de operação deve ser definida com base no principal objetivo: para produção de hidrogênio e ácidos orgânicos a mesofílica é a mais adequada, ao passo que para os álcoois, a termofílica é a mais indicada. A temperatura de $45^{\circ} \mathrm{C}$ não favoreceu nenhum metabolismo de interesse biotecnológico, e portanto, deve ser descartada quando o inóculo tratar-se de fluido de rúmen. Em relação à massa de papel, não foi observado que haja limite máximo de papel que possa ser adicionado, visto que este não foi um parâmetro significativo no desempenho dos lisímetros. 


\section{CONCLUSÕES}

\subsection{Conclusões Hipótese A}

- A estratégia de diluições seriadas foi eficiente para selecionar os microorganismos celulolíticos e acidogênicos, os quais foram identificados em todas as amostras analisadas;

- A estratégia das diluições seriadas levou à minimização/eliminação das arqueias metanogênicas do fluido de rúmen;

- Houve uma redução da riqueza e diversidade de espécies em função da seleção de micro-organismos celulolíticos e acidogênicos após a submissão do fluido de rúmen in natura a diluições seriadas;

\subsection{Conclusões Hipótese B}

- A disponibilidade de água esteve relacionada ao desempenho celulolítico e fermentativo da biomassa microbiana: o teor reduzido de água influenciou negativamente no desempenho do lisímetro;

- O aumento da Temperatura para a faixa termofílica e redução do pH não foram medidas efetivas para maximizar a produção e/ou minimizar o consumo de hidrogênio;

- A massa de substrato (papel) adicionada não teve efeito estatisticamente significativo para a produção dos compostos analisados, ou seja, não influenciou a atividade microbiana de hidrólise e fermentação do papel;

- As variáveis umidade do papel e temperatura foram importantes para o desempenho dos lisímetros; enquanto a umidade determinou a ocorrência de crescimento microbiano nos lisímetros, a temperatura influenciou diretamente nos metabolismos desempenhados pelos micro-organismos e, consequentemente, os produtos de fermentação obtidos;

- Foi possível obter os vetores energéticos ácido acético, etanol e metanol; além de produção dos ácidos butíricos e propiônico em concentrações expressivas a partir da hidrólise e fermentação simultânea do Papel. 


\subsection{Conclusões Hipótese $\mathrm{C}$}

- Para cada temperatura estudada, verificou-se prevalência de gêneros microbianos diferentes: Dysgonomonas para $35^{\circ} \mathrm{C}$, Thermicanus para $55^{\circ} \mathrm{C}$ e Phaeospirillum para $45^{\circ} \mathrm{C}$.

- A temperatura de operação dos lisímetros foi o principal fator de influência nas rotas metabólicas fermentativas desempenhadas pelos micro-organismos; e na estrutura das comunidades microbianas das amostras estudadas;

- As elevadas concentrações de ácido acético no percolado, não acompanhadas de produção de hidrogênio, somada à identificação da espécie homoacetogênica Sporomusa em F.P. e R2 reforça a ocorrência deste metabolismo, principalmente sob condição mesofílica.

\section{RECOMENDAÇÕES}

- Realizar um planejamento experimental para cada temperatura de incubação: mesofílica $\left(37^{\circ} \mathrm{C}\right)$ e termofílica $\left(55^{\circ} \mathrm{C}\right)$, já que a temperatura de $45^{\circ} \mathrm{C}$ não trouxe nenhum resultado positivo;

- Realizar uma agitação no leito de substrato para viabilizar o desprendimento de gás para o headspace, atenuando seu consumo pela microbiota homoacetogênica;

- Manter e controlar a anaerobiose nos lisímetros para favorecer a ocorrência de metabolismos anaeróbios;

- Utilizar água residuária industrial que contenha matéria orgânica e nutrientes, por exemplo vinhaça, soro de leite, entre outras, para umidificar o papel a um teor igual ou maior que $80 \%$, para substituir o uso de água e/ou meio de cultura, potencializando a geração de biocombustíveis;

- Estudar minuciosamente, por meio da identificação microbiana por sequenciamento massivo, os principais micro-organismos do fluido de rúmen, envolvidos na hidrólise de celulose tanto em temperatura 
mesofílica quanto em temperatura termofílica, a fim de enriquecê-los a uma cultura potencialmente celulolítica a ser aplicada em sistemas anaeróbios. 


\section{REFERÊNCIAS}

ABASSI-GUENDOUZ, et al. Total solids drives high solid anaerobic digestion via mass transfer limitation. Bioresource Technology, Barking, v. 111, p. 55-61, 2012.

ADORNO M.A.T.; HIRASAWA, J.S.; VARESCHE, M.B.A. Develpment and validation of two methods to quantify volatile acids (C2-C6) by GC/FID: headspace (automatic and manual) and liquid-liquid extraction (LLE). American Journal of Analytical Chemical, Washington, v. 5, n.7, p. 406-414, 2014.

AKUTSU, Y. et al. Effects of seed sludge on fermentative characteristics and microbial community structures in thermophilic hydrogen fermentation of starch. International Journal of Hydrogen Energy, Oxford, v. 33, p. 6541-6548, 2008.

ALVARADO, C.E. et al. A multivariable evaluation of biohydrogen production by solid substrate fermentation of organic municipal wastes in semi-continuous and batch operation. International Journal of Hydrogen Energy, Oxford, v. 38, p. 1252712538, 2013.

AMERICAN PUBLIC HEALTH ASSOCIATION (APHA); AMERICAN WATER WORKS ASSOCIATION (AWWA); AND THE WATER ENVIRONMENT FEDERATION (WEF). Standard methods for the examination of water and wastewater. 20th edition, American Public Health Association, Washington, D. C, 2005.

ANGENENT, L.T. et al. Production of bioenergy and biochemical from industrial and agricultural wastewater. Trends in Biotechnology, Amsterdam, v. 22, p. 477-485, 2004.

ARANDA USÓN, A. et al. Estimation of the energy content of the residual fraction refused by MBT plants: a case study in Zaragoza's MBT plant. Journal of Cleaner Production, Amsterdam, v. 20, p. 28-46, 2012.

ATLAS, R. M. Handbook of Media for Environmetal Microbiology. 2nd edition. Boca Raton, FL, 2005.

BABA, Y. et al. Improvement of methane production from waste paper by pretreatment with rumen fluid. Bioresource Technology, Barking, v. 128, p. 94-99, 2013.

BALDOCHI, V. M. Z. Resíduos Sólidos Urbanos: Aspectos básicos das transformações de compostos orgânicos em sistemas anaeróbios mesofílicos com elevada concentração de sólidos totais. 1997. 136 F. Tese (Doutorado)-Escola de Engenharia de São Carlos, Universidade de São Paulo, 1997.

BARNES, S.P.; KELLER, J. Anaerobic rumen SBR for degradation of cellulosic material. Water Science Technology, Oxford, v. 50, n. 10, p. 305-311, 2004.

BARROS, A. R. et al. Biohydrogen production in anaerobic fluidized bed reactors: Effect of support material and hydraulic retention time. International Journal of Hydrogen Energy, Oxford, v. 35, n. 8, p. 3379- 3388, 2010. 
BOTTA, L. S. Papel como fonte alternativa para produção anaeróbia de hidrogênio. 2012. 134 F. Dissertação (Mestrado)-Escola de Engenharia de São Carlos - Departamento de Hidráulica e Saneamento, São Carlos - SP, 2012.

BRAGA, A.F.M. Produção de Hidrogênio em reatores anaeróbios termofílicos. 2014. 118 F. Tese (Doutorado), Departamento de Hidráulica e Saneamento, Escola de Engenharia de São Carlos, Universidade de São Paulo, São Carlos, 2014.

BRASIL. Senado Federal. Lei $\mathbf{n}^{\mathbf{0}}$ 12.305, de 2 de agosto de 2010. Institui a Política Nacional de Resíduos Sólidos; altera a Lei no 9.605, de 12 de fevereiro de 1998; e dá outras providências. Disponivel em: < http://www.planalto.gov.br/ccivil_03/_ato20072010/2010/lei/112305.htm >. Acesso em: 19 abr. 2016.

BRAY, J. R.; CURTIS, J.T. An ordination of the upland forest communities of Southern Wisconsin. Ecological Monographs, Durham, v 27, p. 325-349, 1957.

BRUMMER, W. et al. Enzymatic hydrolysis of pretreated waste paper - source of raw material for production of liquid biofuels. Bioresource Technology, Barking, v. 152, p. 543-447, 2014.

BRYANT, M. P. et al. Characteristics of ruminal anaerobic celluloytic cocci and Cillobacterium cellulosolvens n. sp. Journal of bacteriology, Washington, v. 76, p. 529-537, 1958.

Genus Ruminococcus Sijpesteijn 1948, 152AL. In SNEATH, P. H. A. et al. (Ed.). Bergey's manual of systematic bacteriology. Baltimore: The Williams \& WIlkins Co., 1986. v. 2. p. 1093- 1099.

BURGESS, J.G., et al. Matsunaga. Evolutionar y relationships among Magnetospirillum strains inferred from phylogenetic analysis of 16S rDNA sequences. Journal of bacteriology, Washington, v. 175, p. 6689-6694, 1993.

CAI, M. et al. Optimal production of polyhydroxyalkanoates (PHA) in activated sludge fed by volatile fatty acids (VFAs) generated from alkaline excess sludge fermentation, Bioresource Technology, Barking, v. 100, p. 1399-1405, 2009.

CAPORASO, G. et al. QIIME allows analysis of high- throughput community sequencing data. Nature Methods, New York,v. 7, n. 5, p. 335-336, 2010 a.

CAPORASO, J. G.; et al. PyNAST: a flexible tool for aligning sequences to a template alignment. Bioinformatics, Cambridge, v. 26, n. 2, p. 266-267, $2010 \mathrm{~b}$.

CARVER, S. M. et al. Hydrogen and volatile fatty acid production during fermentation of cellulosic substrates by thermophilic consortium at 50 e $60 \mathrm{oC}$. Bioresource

Technology, Barking, v. 104, p. 424-431, 2012.

CHAIRATTANAMANOKORN, P. et al. Additional paper waste in pulping sludge for biohydrogen production by heat-shocked sludge. Applied Biochemistry and Biotechnology, Clifton, v. 166, p. 389-401, 2012.

CHIAN, E.S.K. Stability of organic matter in landfill leachate. Water Research, England, v v. 11, p. 225-232, 1977.

CHOI, J.; CHANG, H.N.; HAN, J. Performance of microbial fuel cell with volatile fatty acids from food wastes. Biotechnology Letters, Dordrecht, v. 33, p. 705-714, 2011.

CHOU, C. et al. Hydrogenesis in hyperthermophilic microorganisms: Implications for biofuels. Metabolic engineering, Orlando, v. 10, n. 6, p. 394-404, 2008. 
CHU, K.H.; FENG, X. Enzymatic conversion of newspaper and office paper to fermentable sugars. Process Safety and Environmental Protection, Rugby, v. 91, p. 123-130, 2013.

COHEN, A. et al. Anaerobic digestion of glucose with separated acid production and methane formation. Water Research, England, v. 33, p. 571-580, 1979.

CUI, M. et al. Optimization of biohydrogen production from beer lees using anaerobic mixed bacteria. International Journal of Hydrogen Energy, Oxford, v. 34, p. 79717978, 2009.

DE BARROS NETO, B.; SCARMINIO, I. S.; BRUNS, R. E. Como Fazer Experimentos: Pesquisa e desenvolvimento na ciência e na indústria, Ed. da Unicamp: Campinas, 2003.

DELFORNO, T. P. Degradação de surfactante aniônico em reator EGSB sob condição metanogênica e ferro redutora com água residuária de lavanderia comercial. 2014. 203 F. Tese (Doutorado)-Escola de Engenharia de São Carlos, Universidade de São Paulo, São Carlos, 2014.

DEMIRBAS, A. Biomass resource facilities and biomass conversion processing for fuels and chemicals. Energy Conversion and Management, Oxford, v. 42, p. 13571378, 2001.

DEMIREL, B.; SCHERER, P. The roles of acetotrophic and hydrogenotrophic methanogens during anaerobic conversion of biomass to methane: a review. Reviews in Environmental Science and Bio/Technology, Dordrecht, v. 7, p. 173-190, 2008.

DESVAUX, M.; GUEDON, E.; PETITDEMANGE, H. Carbon flux distribution and kinetics of cellulose fermentation in steady-state continuous cultures of Clostridium cellulolyticum on a chemically defined medium. Journal of Bacteriology, Nairobi, v. 183 (1), p. 4723-4731, 2001.

DIEKERT, G.; WOHLFARTH, G. Metabolism of homoacetogens. Foundation Antonie van Leeuwenhoek, Boston, v. 66, p. 209-221, 1994.

DILALLO, R.; ALBERTSON, E. Volatile acids by direct tritation. Journal Water Pollution Control Federation, Washington Dc, v. 33, p. 356-365, 1961.

DONG, F. et al. An online-monitored thermophilic hydrogen production UASB reactor for long-term stable operation. International Journal of Hydrogen Energy, Oxford, v. 36, p. 13559-13565, 2011.

DRAKE, H.L.; DANIEL, S.L. Phisiology of the thermophilic acetogen Moorella thermoacetica. Research in Microbiology, Paris, v, 155, p. 869-883, 2014.

DUBOIS, M. et al. Colorimetric method for determination of sugras and related substances. Analytical Chemistry, Illinois, v. 28, p. 350-356, 1956.

DURAND, C.F. et al. Influence of the composition of the cellulolytic flora on the development of hydrogenotrophic microorganisms, hydrogen utilization, and methane production in the rumens of gnotobiotically reared lambs. Applied and Environmental Microbiology, Washington, v. 76, n. 24, p. 7931-7937, 2010.

EASYCHEM. Cellulose. Available on: < http://www.easychem.com.au/production-ofmaterials/biomass-research/cellulose >. Acess: 24 sept. 2016. 
EDGAR, R. C. Search and clustering orders of magnitude faster than BLAST.

Bioinformatics, Cambridge, v. 26, n. 19, p. 2460-1, Oct. 2010.

ELLISTON, A. et al. High concentrations of cellulosic ethanol achieved by fed batch semi simultaneous saccharification and fermentation of waste-paper. Bioresource Technology, Barking, v. 134, p. 117-126, 2013.

ESCOBAR, J.C. et al. O. Biofuels: environment, technology and food security. Renewable and Sustainable Energy Review, Colorado, v. 13, p. 1275-1287, 2009.

FLINT, H.J. et al. Polysaccharide utilization by gut bacteria: potential for new insights from genomic analysis. Nature Reviews, London, v. 6, p. 121-131, 2008.

FRÉSCA, F. R. C. Estudo da Geração dos Resíduos Sólidos Domiciliares no Município de São Carlos, SP, a partir da Caracterização Física. 2007. 134 F. Dissertação (Mestrado)-Escola de Engenharia de São Carlos - Departamento de Hidráulica e Saneamento. 2007.

GHIMIRE, A. et al. A review on dark fementative biohydrogen production from organic biomass: Process parameters and use of by-products. Applied Energy, Barking, v. 144, p. 73-85, 2015.

GHIO, S. et al. Isolation of Paenibacillus sp. and Variovorax sp. strains from decaying woods and characterization of their potential for cellulose deconstruction. International Journal of Biochemistry and Molecular Biology, Madison, v. 3, p. 352-364, 2012;

GIAJ-LEVRA, L. A. Estudo de metodologia de contagem para bactérias anaeróbias celulolíticas. 1991. 140 F. Dissertação (Mestrado). Escola de Engenharia de São Carlos, Universidade de São Paulo, São Carlos, 1991.

GOBNER, A. S. et al. Thermicanus aegyptius gen. nov., sp. nov., Isolated from Oxic Soil, a Fermentative Microaerophile That Grows Commensally with the Thermophilic Acetogen Moorella thermoacetica. Applied and Environmental Microbiology, Washington, v. 65, n. 11, p, 5124-5133, 1999.

GRIFFITHS, R. I., WHITELEY, A. S., O'DONNELL, A. G. rapid method for coextraction of DNA from natural environments for analysis of ribosomal DNA and rRNA- based microbial community composition. Applied and Environmental Microbiology, Washington, v. 66, n. 12, p. 5488-5491, 2000.

GUELL, E.J. et al. Combined heterogeneous catalysis and dark fermentation systems for the conversion of cellulose into biohydrogen. Biochemical Engineering Journal, Amsterdam v. 101, p, 209-219, 2015.

GUJER, W.; ZEHNDER, A.J.B. Conversion Processes in Anaerobic Digestion. Water Science and Technology, Osaka, v. 15, 8-9, p. 127-167, 1983.

HASSAN, M.A. et al. The production of polyhydroxyalkanoate from anaerobically treated palm oil mill effluent by Rhodobacter sphaeroides. Journal of Fermentation and Bioengineering, Osaka, v. 83, p. 485-488, 1997.

HAWKES, F. R. et al. Continuous dark fermentative hydrogen production by mesophilic microflora: principles and progress. International Journal of Hydrogen Energy, Oxford, v. 32, p. 171-184, 2007.

HERBERT, D.; PHILIPPS, O.S.; STRANG, R.E. Carbohydrate analysis. Methods on Enzymology SB, New York, p. 265- 277, 1971. 
$\mathrm{HO}, \mathrm{C}-\mathrm{Y}$. et al. Establishment of functional rumen bacterial consortia (FRBC) for simultaneous biohydrogen and bioethanol production from lignocellulose.

International Journal of Hydrogen Energy, Oxford, v. 36, p. 12168-12176, 2011.

HOFSTAD, T. et al. Dysgonomonas gen. nov. to accommodate Dysgonomonas gadei sp. nov., an organism isolated from a human gall bladder, and Dysgonomonas capnocytophagoides (formerly CDC group DF-3). International Journal of Systematic and Evolutionary Microbiology, London, v. 50, p. 2189-2195, 2000.

HOLDEMAN, L.V., E.P. CATO AND W.E.C. MOORE (Eds). Anaerobe Laboratory Manual. 4th edn. Virginia, Blacksburg, VA: Anaerobe Laboratory; Polytechnic Institute and State University, 1977.

HU, Z. H.; YU, H. Q. Application of rumen microorganisms for enhanced anaerobic degradation of corn stover. Process Biochemistry, London, v. 40, p. 2371-2377, 2005.

HU, Z.H.; YU, H.Q.; ZHENG, J.C. Application of response surface methodology for optimization of acidogenesis of cattail by rumen cultures. Bioresource Technology, Barking, v. 97, p. 2013-2109, 2006.

HUNGATE, R.E. Microorganisms in the rumen of cattle fed a con- stant ration.

Canadian journal of microbiology, Ottawa, v. 3, 289-311, 1957.

HYARIC, R. L. et al. Influence of substrate concentration and moisture content on the specific methanogenic activity of dry mesophilic municipal solid waste digestate spiked with propionate. Bioresource Technology, Barking, v. 102, p. 822-827, 2011.

JIANG, H. et al. Improved cellulose conversion to bio-hydrogen with thermophilic bacteria and characterization of microbial community in continuous bioreactor.

Biomass and Bioenergy, Oxford v. 75, p. 57-64, 2015.

KÁDAR, Z.; SZENGYEL, Z.; RECZEY, K. Simultaneous saccharification and fermentation (SSF) of industrial wastes for the production of ethanol. Industrial Crops and Products, Amsterdam, v. 20, p. 103-110, 2004a.

KÁDAR, Z.; VRIJE, T.; VAN NOORDEN. G.E.; BUDDE, M.A.W.; SZENGYEL, Z.; RÉCZEY, K.; CLAASSEN, P.A.M. Yelds from Glucose, xylose, and paper sludge hydrolysate during hydrogen production by extreme thermophile Caldicellulosiruptor saccharolyticus. Applied Biochemistry and Biotechnology, Clifton, v. 113-116, p. 0497-0508, 2004b.

KAMPFER, P. et al. Cohnella thermotolerans gen. nov., sp. nov., and classification of 'Paenibacillus hongkongensis' as Cohnella hongkongensis sp. nov. International

Journal of Systematic and Evolutionary Microbiology, London, v. 56, p. 781-786, 2006.

KAPDAN, I. K.; KARGI, F. Bio-hydrogen production from waste materials. Enzyme and Microbial Technology, New York, v. 38, 569-582, 2006.

KARADAG, D.; PUHAKKA, J. A. Direction of glucose fermentation towards hydrogen or ethanol production trough on-line $\mathrm{pH}$ control. International Journal of Hydrogen Energy, Oxford, v. 35, p. 10245-10251, 2010.

KARIM, K. et al. Anaerobic digestion of animal waste: effect of mode of mixing. Water research, Oxford, v. 9, n. 15, p. 3597-3606, 2005. 
KARRA, U. et al. Performance of plug flow microbial fuel cell (PF-MFC) and complete mixing microbial fuel cell (CM-MFC) for wastewater treatment and power generation. International Association for Hydrogen Energy, Oxford, n. 38, p. 5383-8, 2013.

KHANAL, S.K. et al. Biological hydrogen production: effects of $\mathrm{pH}$ and intermediate products. International Journal of Hydrogen Energy, Oxford, v. 29, p. 1123-1131, 2003.

KLINDWORTH, A. et al. Evaluation of general 16S ribosomal RNA PCR primers for classical and next-generation sequencing-based diversity studies. Nucleic Acids

Research, London, v. 41, n. 1, p.e1-e1, Aug. 2013.

KONGIAN, P.; ANGELIDAKI, I. Extreme thermophilic biohydrogen production from wheat straw hydrolysate using mixed culture fermentation: Effect of reactor configuration. Bioresource Technology, Barking, v. 101, p. 7789-7796, 2010.

KRIEG, N.R. et al. The Bacterioidetes, Spirochaetes, Tenericutes. (Mollicutes), Acidobacteria, Fibrobacteres, Fusobacteria, Dictyoglomi, Gemmatimonadetes, Lentisphaerae, Verrucomicrobia, Chlamydiae, and Plantomycetes, Bergey's Manual of Systematic Bacteriology. 2 th. New York: Springer, 2010. v.4

KUMAR, G. et al. Lignocellulose biohydrogen: practical challenges and recent progress. Renewable and Sustainable Reviews, Colorado, v. 44, p. 728-737, 2015.

LAY, J-J.; LI, Y-Y.; NOIKE, T. Influences of $\mathrm{pH}$ and moisture content on the methane production in high-solids sludge digestion. Water Research, England, v. 31, n. 6, p. 1518-1524, 1999.

LEE, S. L. et al. A review of the production and applications of waste-derived volatile fatty acids. Chemical Engineering Journal, Lausanne, v. 235, p. 83-99, 2014.

LEE, S. M. et al. Continuous butanol production using suspended and immobilized Clostridium beijerinckii NCIMB 8052 with supplementary butyrate. Energy \& Fuels, Washington, v. 22, p. 3459-3464, 2008.

LEE, Y-E. et al. Taxonomic Distinction of Saccharolytic Thermophilic Anaerobes: Description of Thermoanaerobacterium xylanolyticum gen. nov., sp. nov., and Thermoanaerobacterium saccharolyticum gen. nov., sp. nov.; Reclassification of Thermoanaerobium brockii, Clostridium thermosulfurogenes, and Clostridium thermohydrosulfuricum E100-69 as Thermoanaerobacter brockiicomb. nov., Thermoanaerobacterium thermosulfurigenes comb. nov., and Thermoanaerobacter thermohydrosulfuricus comb. nov., Respectively; and Transfer of Clostridium thermohydrosulfuricum 39E to Thermoanaerobacter ethanolicus. International Journal of Systematic and Evolutionary Microbiology, London, v. 43, 41-51, 1993.

LEITE, V. D. et al. Tratamento anaeróbio de resíduos sólidos orgânicos com alta e baixa concentração de sólidos. Revista Brasileira de Engenharia Agrícola e Ambiental, Campina Grande, v. 13, n. 2, p. 190-196, 2009.

LENS, P. N. L. et al. Biotechnological Treatment of Sulfate-Rich Wastewaters. Critical Reviews in Environmental Science and Technology, Boca Raton, v. 28, n. 1, p. 4188, 1998.

LIMA, D.M.F.; MOREIRA, W.K.; ZAIAT, M. Comparison of the use of sucrose and glucose as a substrate for hydrogen production in an upflow anaerobic fixed-bed 
reactor. International Journal of Hydrogen Energy, Oxford, v. 38, n. 35, p. 1507415083,2013

LOMAN, N.J.; MISRA, R.V.; DALLMAN, T.J.; CONSTANTINIDOU, C.;

GHARBIA, S.E.; WAIN, J.; PALLEN, M.J. Performance comparison of benchtop highthroughput sequencing platforms. Nature Biotechnology, v. 30, p. 434-439, 2012.

LOPES, W.S.; LEITE, W.D. PRASAD, S. Influence of inoculum on performance of anaerobic reactors for treating municipal solid waste. Bioresource Technology,

Barking, v. 94, p. 261-266, 2004.

LUO, G. et al. Long-term effect of inoculum pretreatment on fermentative hydrogen production by repeated batch cultivations: homoacetogenesis and methanogenesis as competitors to hydrogen production. Biotechnology and Bioengineering, New York, v. 108, n. 8, p. 1816-1827, 2011.

LYND, L.R. et al. Microbial cellulose utilization: fundamentals and biotechnology. Microbiology and Molecular Biology Reviews, Washington, v. 66 (3), p. 506-577, 2002.

LYND, L.R.; WYMAN, C.E.; GERNGROSS, T.U. Biocommodity Engineering. Biotechnology Progress, Hoboken v. 15, p. 777-793, 1999.

MCINERNEY, M. J.; BRYANT, M. P. Basic principles of bioconversions in anaerobic digestion and methanogenesis. In: SOFER, S. S. ZABORSKY, O. R. 1981. Biomass conversion processes for energy and fuels. New York: Plenum, 1981. p. 277-296.

MCKENDRY, P. Energy production from biomass (part 1): overview of biomass. Bioresource Technology, Barking, v. 83, p. 37-46, 2002.

MOLLER, B. et al. Sporomusa, a new genus of gram-negative anaerobic bacteria including Sporomusa sphaeroides spec. nov. and Sporomusa ovata spec. nov. Archives of Microbiology, Berlin, v. 139, n. 4, p. 388-389, Nov. 1984.

MOTTE, J.C. et al. Total solids contente: a key parameter of metabolic pathways in dry anaerobic digestion. Biotechnology for Biofuels, London, v. 6, p. 164-169, 2013.

MYERS, R.H. Response Surface Methodology. Boston: Allyn and Bacon Inc., 1986.

NISSILA, M.E. et al. Thermophilic hydrogen production from cellulose with rumen fluid enrichment cultures: effects of different heat treatments. Internantional Journal of Hydrogen Energy, Oxford, v. 36, p. 1482-1490, 2011.

NTAIKOU G., KOUTROS E., KORNAROS M. Valorisation of wastepaper using the fibrolytic/hydrogen producing bacterium Ruminococcus albus. Bioresource Technology, Barking, v. 100, p. 5928-5933, 2009.

NTAIKOU, G., LYBERATOS, A. G. Biohydrogen Production from Biomass and Wastes via Dark Fermentation: A Review. Waste and Biomass Valorization, Netherlands, v. 1, p. 21-39, 2010.

NTAIKOU, I. et al. Hydrogen production from sugars and sweet sorghum biomass using Ruminococcus albus. International Journal of Hydrogen Energy, Oxford, v. 33, p. 1153-1163, 2008.

NUBEL, U.; ENGELEN, B.; FELSKE, A.; SNAIDR, J.; WIESHUBER, A.; AMANN, R.I.; LUDWIG, W.; BACKHAUS, H. Sequence heterogeneities of genes encoding 16S 
rRNAs in Paenibacillus polymyxa detected by temperature gradiente gel electrophoresis. Journal of Bacteriology, Amsterdam, v. 178, p. 5636-5643, 1996.

O’SULLIVAN, C.; BURRELL, P.C.; PASMORE, M. Application of flowcell technology for monitoring biofilm development and cellulose degradation in leachate and rumen systems. Bioresource Technology, Barking, v. 100, p. 492-496, 2009.

PARK, I. et al. Cellulose ethanol production from waste newsprint by simultaneous saccharification saccharification and fermentation using Saccharomyces cerevisiae KNU5377. Process Biochemistry, London, v. 45, p. 487-492, 2010.

PARKIN, G. F.; OWEN, W. F. Fundamentals of anaerobic digestion of wastewater sludges. Journal of environmental engineering, New York, v. 112, p. 86-920, 1986.

PENTEADO, E. D. et al. Influence of seed sludge and pretreatment method on hydrogen production in packed-bed anaerobic reactors. International Journal of Hydrogen Energy, Oxford, v. 38, n. 14, p. 6137-6145, Mayo, 2013.

PETTIPHER, G. L.; LATHAM, M. J. Production of enzymes degrading plant cell walls and fermentation of cellobiose by Ruminococcus flavefaciens in batch and continuous culture. Journal of General Microbiology, London, v. 110, p. 29-38, 1979.

PHILIP, S.; KESHAVARZ, T.; ROY, I. Polyhydroxyalkanoates: biodegradable polymers with a range of applications, Journal of Chemical Technology and Biotechnology, Oxford, v. 82, p. 233-247, 2007.

QUEK, A.; BALASUBRAMANIAN, R. Life cycle assessment of energy and energy carriers from waste matter- a review. Journal of Cleaner Production, Amsterdam, v. 79, p. 18-31, 2014.

RASKIN, L.; RITTMANN, B.E.; STAHL, D.A. Competition and coexistence of sulfate-reducing and methanogenic populations in anaerobic biofilms. Applied and Environmental Microbiology, Washington, v. 62, n. 10, p. 3847-3857, 1996.

RIPLEY, L.F.; ROYLE, W.C.; CONVERSE, J.C. Improved alkalimetric monitoring for anaerobic digestion of poultry manure. Proceeding of the 40th Industrial Waste conference, USA: Purdue University, 1985.

RISMANI-YAZDI, H. et al. Suppression of methanogenesis in cellulose-fed microbial fuel cells in relation to performance, metabolite formation, and microbial population. Bioresource Technology, Barking, v. 129, p. 281-288, 2013.

ROBLEDO-NARVÁEZ, P. N. The influence of total solids content and initial pH on batch hydrogen production by solid substrate fermentation of agroindustrial wastes.

Journal of Environment Management, Amsterdam, v. 128, p. 126-137, 2013.

RODRIGUES, M. I.; IEMMA, A. F. Planejamento de experimentos e otimização de processos. 3 ed. revisada. Campinas: Editora Cárita, 2014.

ROMANO, N. et al. Characterization of Cellulolytic Activities of Environmental Bacterial Consortia from an Argentinian Native Forest. Current Microbiology, New York, v. 67, p. 138-147, 2013.

SAADY, N. M. C. Homoacetogenesis during hydrogen production by mixed cultures dark fermentation: unresolved challenge. International Journal of Hydrogen Energy, Oxford, v. 38, p. 13172-13191, 2013. 
SAADY, N. M. C. et al. Effects of linoleic acid and its degradation by-products on mesophilic hydrogen production using flocculated and granular mixed anaerobic cultures. International Journal of Hydrogen Energy, Oxford, v. 37, p. 18747-18760, 2012.

SAMBROOK, J.; FRITSCH, E.F.; MANIATIS, T. Molecular cloning. 2 nd Ed. New York : Cold Spring Harbor Laboratory Press, 1989

SANGKHARAK, K. Optimization of enzymatic hydrolysis for ethanol production by simultaneous saccharification and fermentation of wastepaper. Waste Management \& Research, London, v. 29, p. 1134-1144, 2011.

SANTOS, S. C. et al. Continuous thermophilic hydrogen production and microbial community analysis from anaerobic digestion of diluted sugar cane stillage.

International Journal of Hydrogen Energy, Oxford, v. 39, p. 9000-9011, 2014.

SAXENA, R.C.; ADHIKARI, D. K.; GOYAL, H.B. Biomass-based energy fuel through biochemical routes: A review. Renewable and Sustainable Energy Reviews, Colorado, v. 13, p. 167-178, 2009.

SCHLAPBACH, L., ZÜTTEL, A. Hydrogen-storage materials for mobile applications. Nature, London, v. 414, p.353-358, 2005.

SCHWARZ, W. H. The cellulosome and cellulose degradation by anaerobic bacteria. Applied Microbiology and Biotechnology, Berlin, v. 56, p. 634-649, 2001.

SHEEHAN, J. J. Biofuels and the conundrum of sustainability. Current Opinion in Biotechnology, London, v. 20, 318-324, 2009.

SHI, A.Z.; KOH, L.P.; TAN, H.T.W. The biofuel potential of municipal solid waste. Global Change Biology Bioenergy, Oxford, v. 1, p. 317-320, 2009.

SHIN, H.S.; YOUN, J.H.; KIM, S.H. Hydrogen production from food waste in anaerobic mesophilic and thermophilic acidogenesis. International Journal of Hydrogen Energy, Oxford, v. 29, p. 1355-1363, 2004.

SIVAGURUNATHAN, P.; SEN, B.; LIN, C-Y. Overcoming propionic acid inhibition of hydrogen by temperature shift strategy. International Journal of Hydrogen Energy, Oxford, v. 39, p. 19232-19241, 2014.

SOKOLOVA, T.G. et al. Thermosinus carboxydivorans gen. nov., sp. nov., a new anaerobic, thermophilic, carbono-monoxide-oxidizing, hydrogenogenic bacterium from hot pool of Yellowstone National Park. International Journal of Systematic and Evolutionary Microbiobiology, London, v. 54, p. 2353-2359, 2004.

SOLOMON, B. O. et al. Comparison of the energetic efficiencies of hydrogen and oxychemicals formation in Klebsiella Pneumoniae and Clostridimn butyricum during anaerobic growth on glycerol. Journal of Biotechnology, Amsterdam, v. 39, p. 107$117,1995$.

SONG, H.; CLARKE, W. P. Cellulose hydrolysis by a methanogenic culture enriched from landfill waste in a semi-continuous reactor. Bioresource Technology, Barking, v. 100, p. 1268-1273, 2009.

SONG, H.; CLARKE, W. P.; BLACKALL, L. L. Concurrent microscopic observations and activity measurements of cellulose hydrolyzing and methanogenic populations 
during the batch anaerobic digestion of crystalline cellulose. Biotechnology and Bioengineering, New York, v. 91, p. 369-378, 2005.

STALEY, B. F., DE LOS REYES III, F. L., BARLAZ, M.A. Effect of spatial differences in microbial activity, $\mathrm{pH}$, and substrate levels on methanogenesis initiation in refuse. Applied and Environmental Microbiology, Washington, v. 77, p. 23812391, 2011.

TCHOBANOGLOUS, G.; THEISEN, H.; VIGIL, S. Integrated solid waste management: engineering principles and management issues. Department of Civil and Environmental Engineering, University of California, Davis, CA, USA, 1993. 978p.

THAUER, R.K.; JUNGERMANN, K.; DECKER, K. Energy conservation in chemotrophic anaerobic bacteria. Bacteriological Reviews, Washington, v. 41, p. 100 $180,1977$.

THOMAS, F. et al. Environmental and gut Bacteroidetes: the food connection. Frontiers in Microbiology, Lausanne, v. 2, artigo 93, 2011.

TSAVKELOVA, E. A.; NETRUSOV, A. I. Biogas production from cellulosecontaining substrates: a review. Applied Biochemistry and Microbiology, New York, v. 48, n. 5, p. 421-433, 2012.

UDOMSRI, S. et al. Clean energy conversion from municipal solid waste and climate change mitigation in Thailand: Waste management and thermodynamic evaluation. Energy for Sustainable Development: the journal of the International Energy Initiative, Bangalore, v. 15, p. 355-364, 2011.

URBANIEC, K.; BAKKER, R.R. Biomass residues as raw material for dark hydrogen fermentation - A review. International Journal of Hydrogen Energy, Oxford, v. 40, p. 3648-3658, 2015.

UYAR, B. et al. Photofermentative hydrogen production from volatile fatty acids present in dark fermentation effluents, International Journal of Hydrogen Energy, Oxford, v. 34, p. 4517-4523, 2009.

VALDEZ-VAZQUEZ, I. et al. Semi-continuous solid substrate anaerobic reactors for $\mathrm{H}_{2}$ production from organic waste: mesophilic versus thermophilic regime.

International Journal of Hydrogen Energy, Oxford, v. 30, p.1383-1391, 2005.

VAN GYLSWYK, N.O. Succiniclasticum ruminis gen. nov., sp. nov., a Ruminal Bacterium Converting Succinate to Propionate as the Sole Energy-Yielding Mechanism. International Journal of Systematic Bacteriology, Ames, v. 45, p. 297-300, 1995.

WANG, H.; REN, Z. J. A comprehensive review of microbial electrochemical systems as a platform technology. Biotechnology Advances, Oxford, v. 31, p. 1796-1807, 2013.

WANG, J., WAN, W. Factors influencing fermentative hydrogen production: a review. International Journal of Hydrogen Energy, Oxford, v. 34, no. 2, p. 799-811, 2009.

WANG, L. et al. Bioethanol production from various waste papers: Economic feasibility and sensitivity analysis. Applied Energy, Barking, v. 111, p. 1172-1182, 2013.

WANG, L.; TEMPLER, R.; MURPHY, R.J. High-solids loading enzymatic hydrolysis of waste papers for biofuel production. Applied Energy, Barking, v. 99, p. 23-31, 2012. 
WANG, Y.; MU, Y.; YU, H-Q. Comparative performance of two upflow anerobic biohydrogen-producing reactors seeded with different sludges. International Journal of Hydrogen Energy, Oxford, v. 32, p. 172-184, 2007.

WEIMER, P.J. Control of product formation during glucose fer- mentation by Bacillus macerans. Journal of General Microbiology, London, v. 130, p. 103-112, 1984.

WEIMER, P. Ruminal Cellulolytic Bacteria: physiology, ecology, and beyond. In: USDA-ARS Proceedings of the Dairy Forage Research Center Conference with the Dairy and Forage Industries, Madison, WI, 1996. p. 53-60.

WEJIMA, J. et al. Competition for $\mathrm{H}_{2}$ between sulfate reducers, methanogens and homoacetogens in a gas-lift reactor. Water Science Technology, Oxford, v. 45, p. 7580, 2002.

WOOD, H. G.; LJUNGDAHL, L. G. Autotrophic character of aceto- genic bacteria, In J. M. SHIVELY, J. M. ; BARTON, L. L. (Ed.). Variations in autotrophic life. San Diego, Calif: Academic Press, 1991. p. 201-250.

WU, F-C.; HUANG, S-S.; SHIH, I-L. Sequential hydrolysis of waste newspaper and bioethanol production from the hydrolysate. Bioresource Technology, Barking, v. 167, p. 159-168, 2014.

YABUUCHI, E.; YANO, I. Achromobacter gen. nov. and Achromobacter xylosoxidans (ex Yabuuchi and Ohyama 1971) nom. rev. International journal of systematic bacteriology, Ames, n. 31, p. 477-478, 1981.

YAMAMURO, A. et al. Metanogenomic analyses reveals the involvement of syntrophic consortia in methanol/electricity conversion in microbial fuel cells. Plos One, San Francisco, v. 9, n. 5, p. e98425, 2014.

YANG, H. Y. et al. Selection and characteristics of a switchgrass-colonizing microbial community to produce extracelular celulases and xylanases. Bioresource Technology, Barking, v. 102, p. 3546-3550, 2011.

YANG, Y.J. et al. Dysgonomonas macrotermitis sp. nov., isolated from the hindgut of a fungus-growing termite. International Journal of Systematic and Evolutionary Microbiology, London, v. 64, p. 2956-2961, 2014.

YEN, H-W; BRUNE, D. E. Anaerobic co-digestion of algal sludge and waste paper to produce methane. Bioresource Technology, Barking, v. 98, p. 130-134, 2007.

YUE, Z-B.; LI, W-W; YU, H-Q. Application of rumen microorganisms for anaerobic bioconversion of lignocellulosic biomass. Bioresource Technology, Barking, v. 128, p. 738- 744, 2013.

ZHANG, Y. et al. Electricity generation and microbial community response to substrate changes in microbial fuel cell. Bioresource Technology, Barking, v.102, p. 1166-1173, 2011.

ZHENG, X.; CHEN, Y.; LIU, C. Waste activated sludge alkaline fermentation liquid as carbon source for biological nutrients removal in anaerobic followed by alternating aerobic-anoxic sequneching batch reactors. Chinese Journal of Chemical Engineering, Beijing, v. 18, p. 478-485, 2010. 